\title{
AVALIAÇÃO DO COMPORTAMENTO DE PAVIMENTOS COM CAMADA RECICLADA DE REVESTIMENTOS ASFÁLTICOS A FRIO COM EMULSÃO MODIFICADA POR POLÍMERO
}

Dissertação apresentada à Escola Politécnica da Universidade de São Paulo para obtenção do Título de Mestre em Engenharia de Transportes.

Área de Concentração:

Engenharia de Transportes

Orientadora:

Prof $^{a}$. Dr a Liedi Légi Bariani Bernucci 

AMANDA HELENA MARCANDALI DA SILVA

\section{AVALIAÇÃO DO COMPORTAMENTO DE PAVIMENTOS COM CAMADA RECICLADA DE REVESTIMENTOS ASFÁLTICOS A FRIO COM EMULSÃO MODIFICADA POR POLÍMERO}

Dissertação apresentada à Escola Politécnica da Universidade de São Paulo para obtenção do Título de Mestre em Engenharia de Transportes.

Área de Concentração:

Engenharia de Transportes

Orientadora:

Prof ${ }^{a}$. Dr ${ }^{\mathrm{a}}$. Liedi Légi Bariani Bernucci

São Paulo 
Este exemplar foi revisado e alterado em relação à versão original, sob responsabilidade única do autor e com a anuência de seu orientador.

São Paulo, 15 de junho de 2011.

Assinatura do autor

Assinatura do orientador

\section{FICHA CATALOGRÁFICA}

Silva, Amanda Helena Marcandali

Avaliação do comportamento de pavimentos com camada reciclada de revestimentos asfálticos a frio com emulsão modificada por polímero / A.H.M. Silva. -- ed.rev. -- São Paulo, 2011. 143p.

Dissertação (Mestrado) - Escola Politécnica da Universidade de São Paulo. Departamento de Engenharia de Transportes.

1. Pavimentos flexíveis (Restauração; Reciclagem) 2. Asfalto I. Universidade de São Paulo. Escola Politécnica. Departamento de Engenharia de Transportes II. t. 
À minha família, sem a qual nada faria sentido. 


\section{AGRADECIMENTOS}

À meus pais Ilda e Sidney, pelo amor, exemplo e incentivo incondicionais.

À meus irmãos, Junior, Felipe e Rafael, que abrem meus olhos com as verdades que me protegem.

À minha orientadora Profa. Liedi Bernucci, pelo carinho com que me recebeu, me orientou e me mostrou um novo mundo.

Ao Prof. Carlos Suzuki por toda a disposição em ensinar e orientar prontamente.

Aos meus grandes amigos Ana Luisa Aranha e Santi Ferri, que tanto contribuíram neste trabalho.

À toda a equipe do LTP, que colaborou para a realização desta dissertação, em especial às grandes amigas Rosângela Motta, Kamilla Vasconcelos e Diomária Santos.

Ao Grupo OHL Brasil, pela parceria na realização desta pesquisa, em especial aos Eng. José Mario Chaves, Eng. Daniele Rodrigues e Eng. Arnaldo Silva Jr.

À ANTT, por possibilitar a realização de pesquisas práticas em parceria com a Universidade, em especial ao Eng. Stephane Quebaud, por ter participado ativamente do desenvolvimento desta pesquisa.

À Dynatest Engenharia, representada pela equipe André Vale, Douglas Negrão e Felipe Camargo.

À Brown\&Brown, em especial ao Eng. Adilson Vinha, que gentilmente me recebeu na execução do trecho experimental.

Ao CNPq, pela bolsa de mestrado. 


\section{RESUMO}

Esta pesquisa avaliou a técnica de reciclagem a frio in situ com emulsão modificada por polímero de revestimentos asfálticos deteriorados, por meio de análises dos resultados de ensaios laboratoriais e avaliações de trecho experimental executado na Rodovia Régis Bittencourt, atualmente sob concessão do Grupo OHL Brasil. Os ensaios laboratoriais foram conduzidos a fim de se verificar a influência da variabilidade dos agregados fresados $\overline{\bar{j}}_{\overline{\mathrm{O}}}$ e $\mathrm{o}$ efeito do teor e do tipo de emulsão asfáltica (modificada por polímero e convencional) na dosagem de misturas recicladas a frio, utilizando resultados de comportamento mecânico como parâmetros de avaliação. Os ensaios de laboratório mostraram a eficiência das emulsões modificadas por polímero sobre as convencionais e a importância do período de cura nas propriedades mecânicas. Valores de módulo de resiliência determinados em laboratório ficaram próximos aos módulos das camadas em campo obtidos por retroanálise estrutural, oscilando entre 1.000 a $1.500 \mathrm{MPa}$. A concepção do experimento de campo permitiu variar a espessura da camada reciclada $(80,110$ e $150 \mathrm{~mm}$ ) e o tipo de revestimento asfáltico sobre esta (microrrevestimento asfáltico a frio e concreto asfáltico com $40 \mathrm{~mm}$ de espessura), resultando em seis segmentos analisados. $O$ acompanhamento da execução contribuiu para compreender as vantagens e limitações do grupo de equipamentos utilizados em campo para a reciclagem. O monitoramento dos segmentos experimentais permitiu verificar que a solução de reciclagem asfáltica in situ traz uma melhoria para a condição estrutural e funcional dos pavimentos. As deflexões são reduzidas pela reciclagem a frio e as bacias de deflexão mostram um aumento no raio de curvatura, ressaltando a melhoria estrutural decorrente da reciclagem. O estudo de campo, que incluiu o acompanhamento por mais de 2 anos de vida em serviço permitiram concluir que a reciclagem asfáltica a frio de revestimentos deteriorados pode ser empregada para tráfego pesado, podendo ser executada em diferentes espessuras, variando de acordo com o estado da camada deteriorada e das deflexões da estrutura remanescente antes da reciclagem. O microrrevestimento asfáltico a frio pode ser executado sobre a camada reciclada asfáltica, sendo eficiente por tempo limitado, dependendo das deflexões obtidas após restauração; após certo período deve ser executada uma camada de concreto asfáltico como reforço. As 
observações de pista mostraram que a drenagem adequada dos pavimentos é uma característica fundamental para o bom desempenho da solução de reciclagem a frio. 


\begin{abstract}
This research evaluated in situ cold recycling with emulsion modified by deteriorated asphaltic coating polymer, by analyzing the lab tests results and evaluating Rodovia Régis Bittencourt's experimental stretch, currently under Grupo OHL Brasil's concession. The lab tests were conducted in order to verify the milled aggregates' variety and the effect of the asphaltic emulsion's (modified by polymer or conventional) content and type on the cold recycled mixtures dosage, utilizing mechanical behavior results as evaluation parameters. The lab tests show the polymer modified emulsion's efficiency over the conventional and the importance of the healing period for the mechanical properties. Lab determined resilience module values were close to the field modules acquired via structural back-analysis, oscillating between 1,000 to $1,500 \mathrm{MPa}$. The field experiment's conception permitted variation of recycled layer thickness $(80,110$, and $150 \mathrm{~mm})$ and its type of asphaltic coating (cold asphaltic micro-coating and $40 \mathrm{~mm}$ thick asphaltic concrete), resulting in six analyzed segments. The monitoring of the execution contributed to the comprehension of the advantages and limitations of the equipment used for recycling in the field. In monitoring the experimental stretches, there was positive verification that the in situ asphaltic recycling solution brought about better structural and functional condition to the pavements. Deflections were reduced by the cold recycling, and the deflection basins show an increase in curvature radius, thus enhancing structural improvements due to recycling. The field study, that includes monitoring for over 2 years of service life, conclude that the cold asphaltic recycling of deteriorated coatings can be used for heavy traffic, being executable in different thicknesses, varying according to the deteriorated layer's state and remnant structure deflections prior to recycling. The cold asphaltic micro-coating can be executed over the asphaltic recycled layer, with limited time efficiency, depending on the acquired deflection after restoration; after a determined period of time, an asphaltic concrete layer must be executed for strengthening. Track observations show that the pavements' adequate drainage is a fundamental characteristic for the cold recycling solution's performance.
\end{abstract}




\section{LISTA DE ILUSTRAÇÕES}

Figura 1 - Diferentes aplicações em misturas do agregado fresado..........................

Figura 2 - Técnicas de reciclagem de pavimentos asfálticos

Figura 3 - Estrutura das emulsões asfálticas em diferentes estágios (Modificado a partir de Clerman, 2006)

Figura 4 - Sequência de equipamentos para a reciclagem a frio in situ com trem de reciclagem (Fonte: Brown\&Brown, 2009) .33

Figura 5 - Retirada de agregado fresado, antes da misturação com emulsão .37

Figura 6 - Espalhamento dos agregados fresados em laboratório .38

Figura 7 - Peagâmetro na determinação do pH com agregados graúdos e finos.....38 Figura 8 -Ensaio de abrasão Los Angeles (a) para agregados fresados, livres de pó (b) e lavados (c) 39

Figura 9 - Equipamento para determinação da forma dos agregados (a) e porções de material, separados segundo o índice de forma (b)

Figura 10 - Distribuição granulométrica média dos agregados fresados obtida por peneiramento de quatro amostras

Figura 11 - Compactação (a) e cura dos corpos-de-prova (b) e (c) ........................46

Figura 12 - Peneiramento (a) e adição de cimento na mistura reciclada (b) ...... 47

Figura 13 - Resultado das medidas de volume de vazios (a) e massa especifica aparente (b), dosagem Marshall - versus teor de umidade 48

Figura 14 - Pesagem (a) e Adição de água na mistura reciclada (b).......................48

Figura 15 - Pesagem (a) e Adição de emulsão na mistura reciclada (b) .... .49

Figura 16 - Determinação da densidade máxima teórica - ensaio Rice (a), e amostra de mistura reciclada (b)

Figura 17 - Resultados da determinação da massa específica máxima teórica pelo ensaio Rice versus teor de emulsão modificada ..... .50

Figura 18 - Métodos de determinação da massa específica aparente: paquímetro (a) e parafina (b) e (c)

Figura 19 - Resultados de peso específico aparente versus teor de emulsão modificada.

Figura 20 - Volume de vazios versus teor de emulsão modificada. .52

Figura 21 - Equipamento e ensaio de estabilidade. .53

Figura 22 - Estabilidade Marshall x Teor de Emulsão 
Figura 23 - Ensaio de resistência à tração por compressão diametral

Figura 24 - Resultados de ensaios de resistência à tração para os teores de emulsão modificada

Figura 25 - Banho a $60^{\circ} \mathrm{C}$ (a) e a $25^{\circ} \mathrm{C}$ (b) para o ensaio de perda por umidade induzida

Figura 26 - Moldagem (a) e pesagem (b) de corpo-de-prova e ensaio de módulo de resiliência triaxial (c)

Figura 27 - Módulo de resiliência de amostras com variação no período de cura.....58

Figura 28 - Comparativo de volume de vazios .59

Figura 29 - Comparativo de massa específica aparente .59

Figura 30 - Resistência à tração com e sem condicionamento

Figura 31 - Comparativo de perda por umidade induzida

Figura 32 - Tambor Los Angeles (a) e aspecto do corpo-de-prova após ter sido submetido a 200 rotações

Figura 33 - Faixa granulométrica do CBUQ executado como camada de revestimento no trecho experimental

Figura 34 - Volume de vazios (a) e peso específico aparente do concreto asfáltico (b)

Figura 35 - Faixa granulométrica do microrrevestimento asfáltico a frio executado no trecho experimental .65 Figura 36 - Rodovia Régis Bittencourt entre São Paulo e Curitiba, sob concessão da Autopista Régis Bittencourt - Trecho experimental na cidade de Registro.

Figura 37 - Estrutura de pavimento existente no trecho experimental, antes da restauração .68

Figura 38 - Trincamento existente no trecho experimental antes da restauração ....69 Figura 39 - Deformação permanente em trilha de roda no trecho experimental antes da restauração 69

Figura 40 - Levantamento deflectométrico no trecho experimental, antes da intervenção...... .70

Figura 41 - Resumo de dados de precipitação e temperatura na região do trecho experimental no período da pesquisa. Fonte: Inmet, 2010 .73

Figura 42 - Configuração esquemática do trecho experimental .75

Figura 43 - Segmento reciclado com adição de cal - diversas intervenções após 3 meses da execução da camada de revestimento em microrrevestimento 
Figura 44 - Representação da estrutura do pavimento no trecho experimental após restauração

Figura 45 - Aparência superficial homogênea do pavimento após a fresagem .........79

Figura 46 - Trem de reciclagem utilizado na restauração do trecho experimental ...80

Figura 47 - Seqüência executiva da reciclagem a frio in situ................................81

Figura 48 - Distribuição de aditivo antes da fresagem.......................................... 82

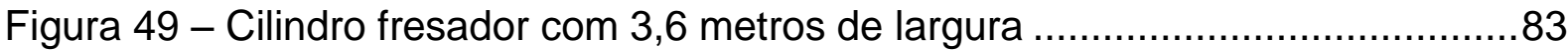

Figura 50 - Faixa junto ao canteiro central, com fresagem previa e execução concomitante com faixa I de rolamento...

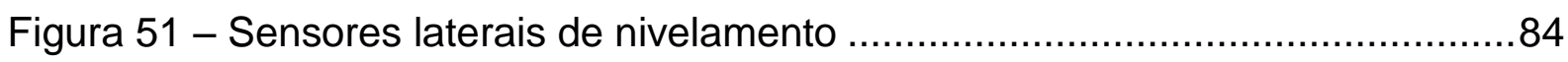

Figura 52 - Rodo para arraste e distribuição de agregados soltos ..........................84

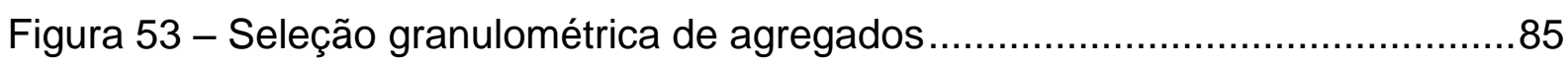

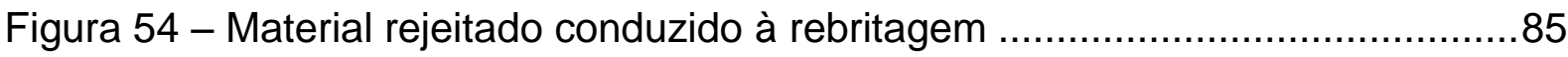

Figura 55 - Adição de emulsão no tanque de misturação final ...............................86

Figura 56 - Espargidores para realização de pintura de ligação...............................86

Figura 57 - Vibroacabadora com distribuição por rosca sem fim ............................87

Figura 58 - Acabadora desconectada do trem de reciclagem ................................87

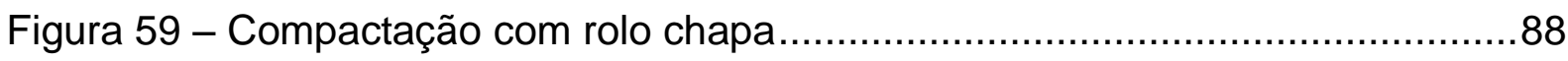

Figura 60 - Salgamento do pavimento reciclado antes da abertura ao tráfego .........88

Figura 61 - Segmentos de reciclagem com cal e microrrevestimento,

respectivamente em março/2009 (a) e março/2010 (b)

Figura 62 - Representação esquemática dos pontos de extração de corpos-de-prova no trecho experimental

Figura 63 - Corpos-de-prova extraídos por sonda rotativa do trecho experimental indicando as características das estruturas executadas

Figura 64 - Local de extração de corpo-de-prova no trecho experimental (a); corpode-prova extraído (b) e posteriormente faceado nas dimensões Marshall (c) 93 Figura 65 - Corpos-de-prova submetidos a medidas de densidade (a), ensaio Cântabro (b) e ensaio de Módulo de Resiliência (c).

Figura 66 - Placas extraídas do trecho experimental (a), faceadas (b) e ensaiadas no simulador de tráfego tipo LPC de laboratório (c)

Figura 67 - Índice de Irregularidade Longitudinal - Faixa I...................................95

Figura 68 - Índice de Irregularidade Longitudinal - Faixa II ..................................96

Figura 69 - Irregularidade longitudinal na faixa I do trecho experimental 
Figura 70 - Segmentos reciclados com cimento e camada de revestimento em concreto asfáltico (a) e em microrrevestimento (b), respectivamente - Imediatamente após restauração - março/2009

Figura 71 - Segmentos reciclados com cimento e camada de revestimento em concreto asfáltico (a) e em microrrevestimento (b), respectivamente - após um ano de vida em serviço - março/2010. .98

Figura 72 - Simulador de Tráfego instalado no Trecho Experimental (a); segmento submetido ao ensaio (b) .99

Figura 73 - Simulador de Tráfego instalado na Faixa II - desvio de tráfego 100

Figura 74 - Medidas deflectométricas para todas as campanhas realizadas no período da pesquisa na faixa I do trecho experimental

Figura 75 - Medidas deflectométricas para todas as campanhas realizadas no período da pesquisa na faixa II do trecho experimental 102

Figura 76 - Proporção de faixas de deflexão no trecho experimental - Faixa I Outubro/2008 - antes da intervenção

Figura 77 - Proporção de faixas de deflexão no trecho experimental - Faixa I Março/2009 - após a intervenção

Figura 78 - Proporção de faixas de deflexão no trecho experimental - Faixa I Março/2010 - após um ano da intervenção 104

Figura 79 - Proporção de faixas de deflexão no trecho experimental - Faixa I Fevereiro/2011 - após dois anos da intervenção. 104

Figura 80 - Análise de desempenho dos segmentos reciclados em $8 \mathrm{~cm}$ de espessura......

Figura 81 - Análise de desempenho dos segmentos reciclados em $11 \mathrm{~cm}$ de espessura 106

Figura 82 - Análise de desempenho dos segmentos reciclados em $15 \mathrm{~cm}$ de espessura

Figura 83 - Raio de curvatura médio nos segmentos com microrrevestimento em função de quatro campanhas de medidas de deflexão

Figura 84 - Métodos para obtenção da área da bacia de deflexão 115

Figura 85 - Retroanálise da estrutura antes da intervenção

Figura 86 - Retroanálise da estrutura com camada reciclada em $8 \mathrm{~cm}$, após a intervenção. 
Figura 87 - Retroanálise da estrutura com camada reciclada em $11 \mathrm{~cm}$, após a intervenção.

Figura 88 - Retroanálise da estrutura com camada reciclada em $15 \mathrm{~cm}$, após a intervenção.

Figura 89 - Retroanálise da estrutura com camada reciclada em $8 \mathrm{~cm}$, a partir das deflexões de junho/2009, após a intervenção 119 Figura 90 - Retroanálise da estrutura com camada reciclada em $11 \mathrm{~cm}$, a partir das deflexões de junho/2009, após a intervenção 119 Figura 91 - Retroanálise da estrutura com camada reciclada em $15 \mathrm{~cm}$, a partir das deflexões de junho/2009, após a intervenção 120 Figura 92 - Efeito da espessura de CBUQ na variação da deformação, com subleito em módulo equivalente de $100 \mathrm{MPa}$ (a) e de $300 \mathrm{MPa}$ (b) 125 Figura 93 - Efeito da variação da espessura de revestimento e da espessura reciclada na deformação do camada reciclada e no número $\mathrm{N}$ admissível 125 


\section{LISTA DE TABELAS}

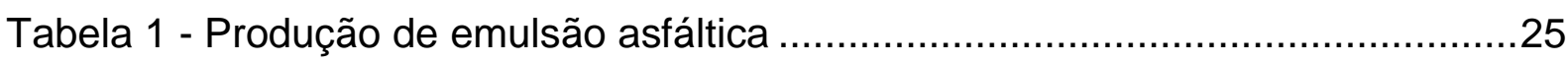

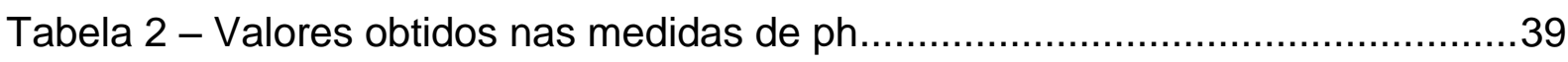

Tabela 3 - Amostras submetidas a ensaio de abrasão Los Angeles ..........................40

Tabela 4 - Análise Granulométrica de amostras de agregado fresado no trecho

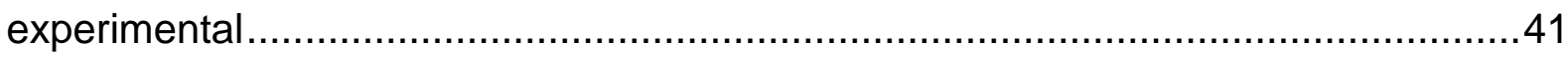

Tabela 5 - Caracterização de emulsões com polímero. Fonte: ANP, 2009 …...........43

Tabela 6 - Características da emulsão utilizada nesta pesquisa .............................44

Tabela 7 - Resumo de resultados dos ensaios de laboratório ..................................4

Tabela 8 - Resultados dos ensaios de resistência à tração em amostras com e sem

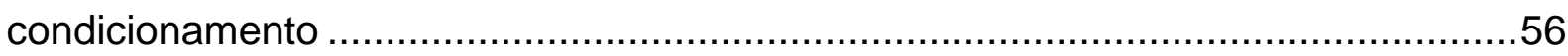

Tabela 9 - Perda por umidade induzida nas misturas com emulsão convencional e

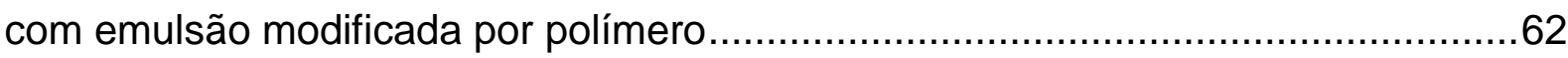

Tabela 10 - Resultados de perda no ensaio Cântabro para as misturas comparadas

Tabela 11 - Componentes da mistura de microrrevestimento executado .65

Tabela 12 - Porcentagem das categorias de veículos utilizadas na definição do

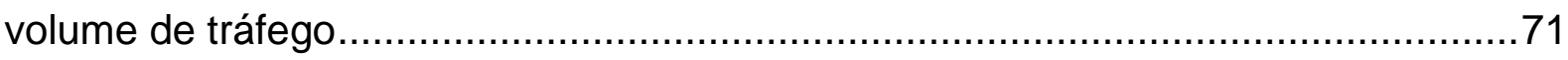

Tabela 13 - Fatores considerados e cálculo do Número N....................................71

Tabela 14 - Número N de projeto …………………...................................

Tabela 15 - Módulo de Resiliência de amostras do trecho experimental ..................94

Tabela 16 - Fator de correção sazonal - DNER PRO 11/1979 ............................101

Tabela 17 - Resumo das médias e desvio padrão das medidas de deflexão ..........105

Tabela 18 - Valores do coeficiente K para misturas asfálticas recicladas ..............109

Tabela 19 - Comparação de vida útil baseada nas deflexões e do $\mathrm{N}$ atuante real no ano de 2009 - Método PRO 11/79

Tabela 20 - Comparação de vida útil baseada nas deflexões e do $\mathrm{N}$ atuante real no ano de 2009 - Método PRO 269/94.

Tabela 21 - Faixas de Classificação do Parâmetro Área da Bacia de Deflexão (WsDOT/2005)

Tabela 22 - Resultados médios do Parâmetro Área para cada segmento, em quatro campanhas de medição deflectométrica 116

Tabela 23 - Resumo dos módulos de resiliência obtidos por retroanálise 120 
Tabela 24 - Resultados de Módulo de Resiliência - DNER PRO 269/94 122

Tabela 25 - Resumo dos resultados de Módulo de Resiliência obtidos em laboratório 122

Tabela 26 - Resumo dos Módulos de Resiliência. 123 


\section{LISTA DE ABREVIATURAS E SIGLAS}

AASHO - American Association of State Highway Officials

AASHTO - American Association of State Highway and Transportation Officials

ABEDA - Associação Brasileira das Empresas Distribuidoras de Asfalto

ABNT NBR - Associação Brasileira de Normas Técnicas

ANP - Agencia Nacional do Petróleo

ARRA - Asphalt Recycling \& Reclaiming Association

ASTM - American Society for Testing and Materials

BGS - Brita Graduada Simples

CaDOT - California Department of Transportation

CAP - Cimento Asfáltico de Petróleo

CBUQ - Concreto Betuminoso Usinado a Quente

CIA - Central Intelligence Agency

CNT - Confederação Nacional dos Transportes

CONAMA - Conselho Nacional do Meio Ambiente

Do - Deflexão Máxima

Dc - Deflexão Característica

DCP - Dynamic Cone Penetrometer

DER - Departamento de Estradas de Rodagem

DMT - Densidade Máxima Teórica

DNER - Departamento Nacional de Estradas de Rodagem

DNIT - Departamento Nacional de Infra-Estrutura de Transportes

DUI - Dano por Umidade Induzida

EMBRAPA - Empresa Brasileira de Pesquisa Agropecuária

EPA - Environmental Protection Agency

FC - Fissura classe

Fcresc - Fator de crescimento

FDR - Full Depth Reclamation

FHWA - Federal Highway Administration

FV - Fator de Veículo

FWD - Falling Weight Deflectometer

Gmb - Massa Específica Aparente

$\mathrm{He}$ - Espessura 
HVS - Heavy Vehicle Simulator

IRI - Índice de Irregularidade Longitudinal

LPC - Laboratoire des Points et Chaussées

Mef - Módulo Efetivo

MnDOT - Minnesota Department of Transportation

$\mathrm{MPa}$ - Mega Pascal

MR - Módulo de Resiliência

$\mathrm{N}$ - Número $\mathrm{N}$

NLT - Normas del Laboratorio de Transportes

ODOT - Oregon Department $f$ Transportation

PAC - Programa de Aceleração do Crescimento

PaDOT - Pennsylvania Department of Transportation

PIARC - World Road Association

PMSP - Prefeitura Municipal de São Paulo

RAP - Reclaimed Asphalt Pavement

$\mathrm{RL}$ - Ruptura Lenta

RM - Ruptura Média

RR - Ruptura Rápida

RT - Resistência à Tração

SBS - Estireno Butadieno Estireno

VDM - Veículos Diários Médios

USACE - United States of Army Corps of Enginners

WsDOT - Washington Department of Transportation 


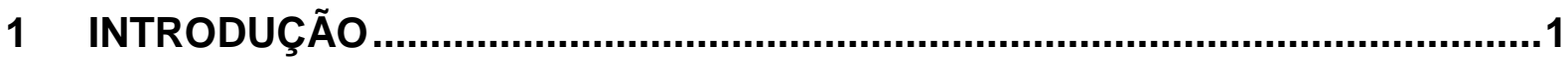

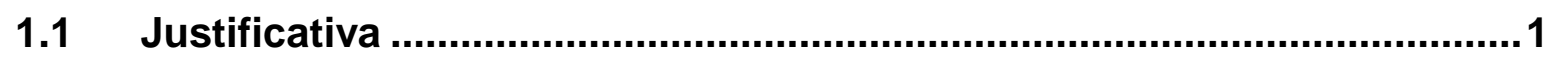

1.2 Objetivo

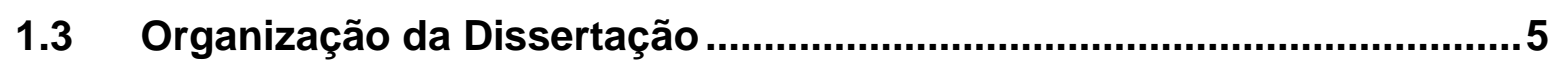

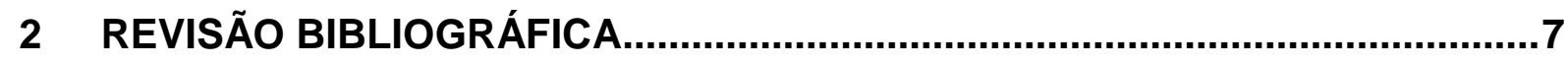

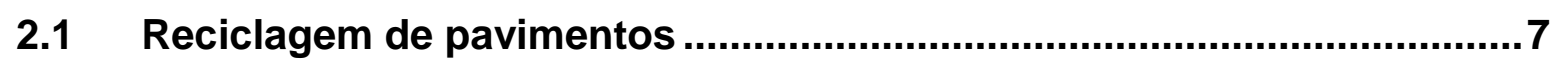

2.2 Resíduos Sólidos Provenientes da Pavimentação .................................10

2.3 Técnicas de Reciclagem de Pavimentos Asfálticos - Internacionais .. 12

2.4 Técnicas de Reciclagem de Pavimentos Asfálticos - Nacionais...........15

2.5 Reciclagem de Pavimentos a Frio in situ com Emulsão ......................17

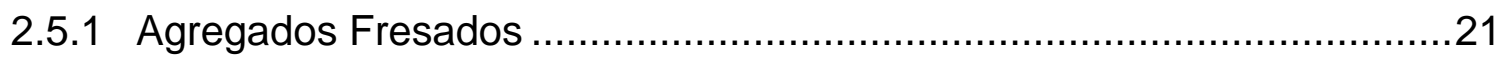

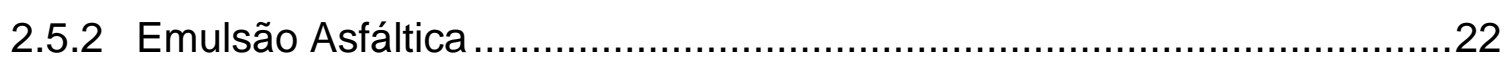

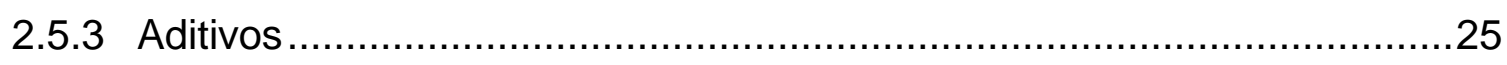

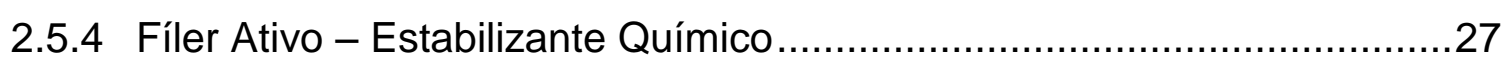

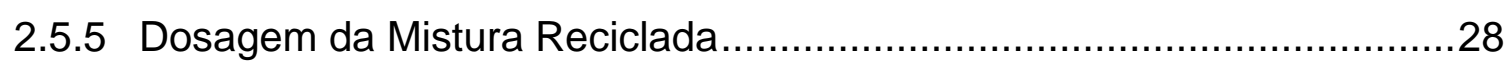

2.5.6 Propriedades Mecânicas de Misturas Recicladas em Laboratório ...........31

2.5.7 Equipamentos de Execução em Campo ...............................................32

2.5.8 Controle Tecnológico de Campo .......................................................33

2.6 Algumas Experiências Nacionais e Internacionais...............................35

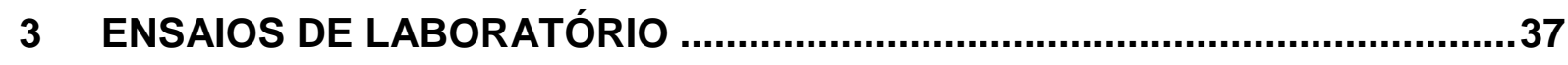

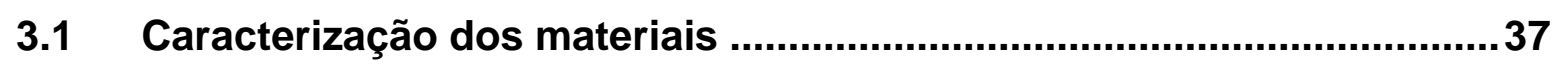

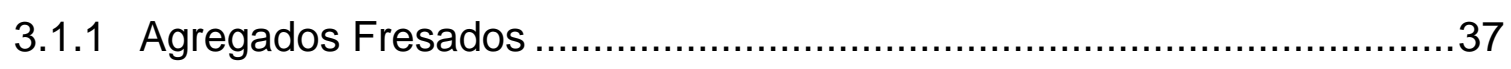

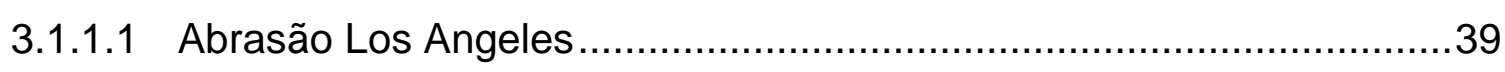

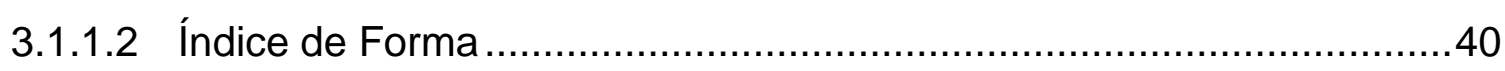

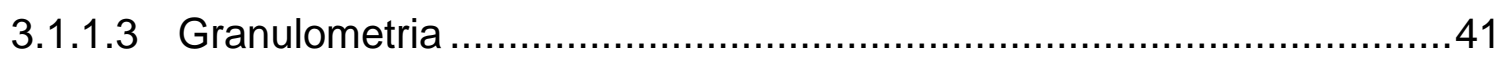

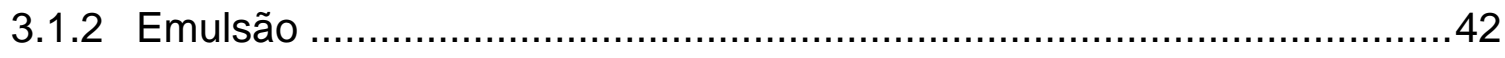

3.2 Dosagem da Mistura Reciclada ........................................................ 45

3.2.1 Composição Granulométrica ........................................................ 46 


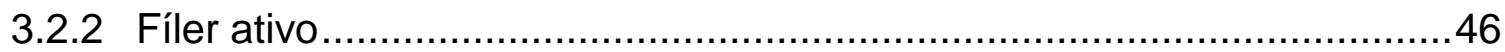

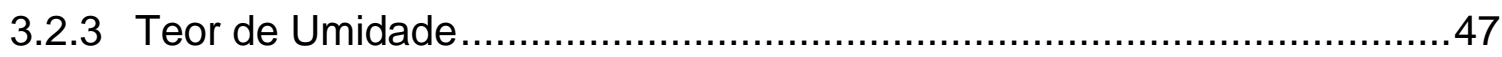

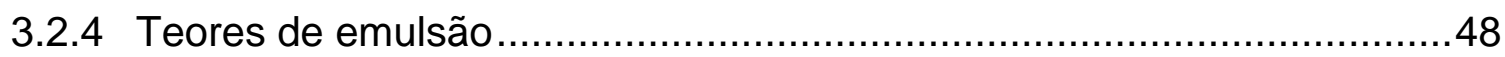

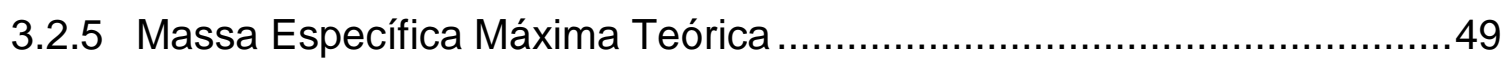

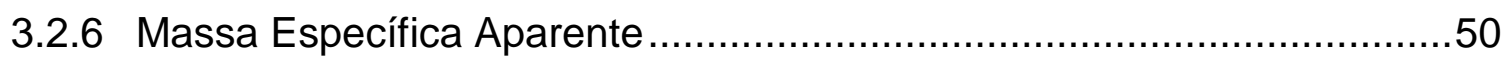

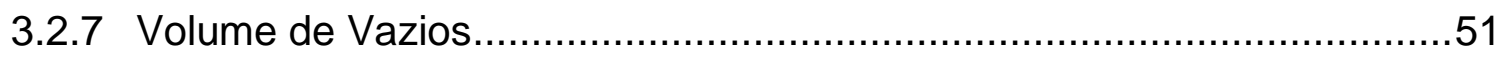

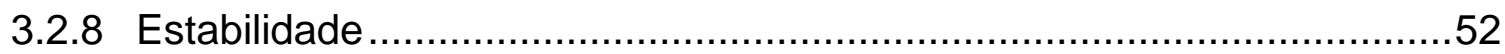

3.2.9 Teor de Emulsão e Teor de Água Selecionado ......................................54

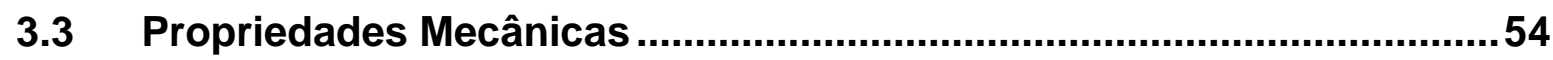

3.3.1 Resistência à Tração por Compressão Diametral ..................................54

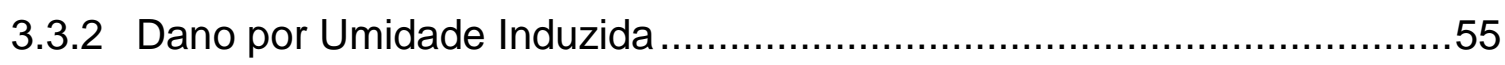

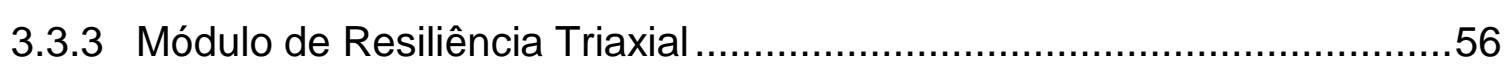

3.4 Comparativo entre Misturas Recicladas com Diferentes Emulsões ....58

3.5 Características dos Materiais Empregados como Camada de

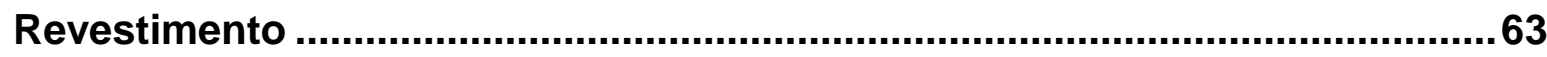

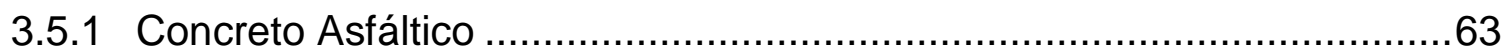

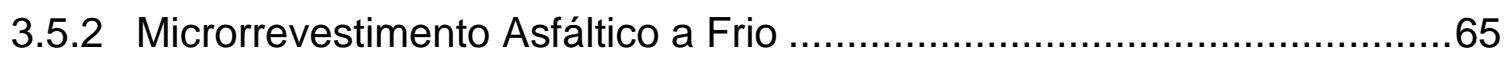

4 EXPERIMENTO DE CAMPO - RODOVIA RÉGIS BITTENCOURT ..................66

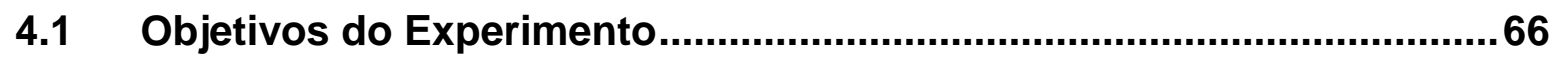

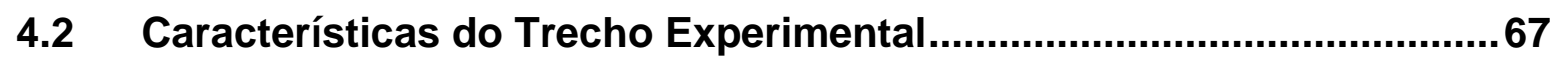

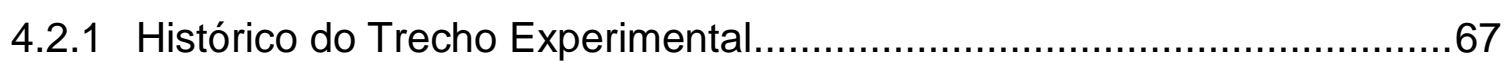

4.2.2 Volume de Tráfego ....................................................................

4.2.3 Fatores Climáticos e Ambientais .........................................................72

4.3 Solução de Restauração Indicada no Projeto ........................................74

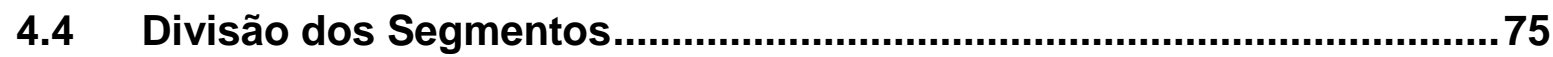

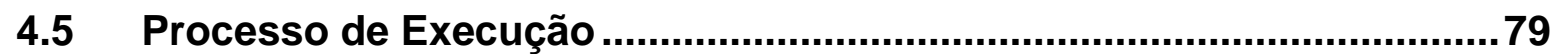

5 MONITORAMENTO DE DESEMPENHO DO TRECHO EXPERIMENTAL .......90

$5.1 \quad$ Amostragem do Trecho Experimental …............................................92

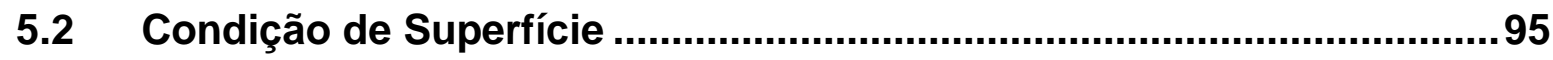

5.3 Simulador de Tráfego em Escala Real ...................................................98 
5.4 Deflexões do Pavimento do Trecho Experimental ...............................100

5.4.1 Avaliação pelo Método DNER - PRO 11/79 …….............................108

5.4.1.1 Fator de Redução de Deflexão ......................................................108

5.4.1.2 Raio de Curvatura da Bacia de Deflexão ........................................110

5.4.1.3 Estimativa de Vida Remanescente - PRO 11/79...........................111

5.4.2 Estimativa de Vida Remanescente - PRO 269/94 …........................113

5.4.3 Parâmetro Área da Bacia de Deflexão ................................................114

5.5 Determinação do Módulo de Resiliência da Mistura Reciclada ..........116

5.5.1 Determinação por Retroanálise ....................................................117

5.5.2 Determinação pelo Método de Dimensionamento de Reforço DNER -

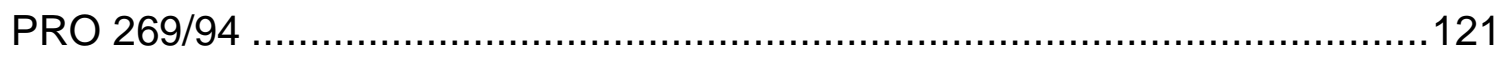

5.5.3 Determinação do Módulo de Resiliência em Laboratório ......................122

5.5.4 Comparativo de Módulo de Resiliência da Camada Reciclada ..............123

5.6 Efeito da Camada de Rolamento …..................................................124

6 CONCLUSÕES E RECOMENDAÇÕES .....................................................127

REFERÊNCIAS BIBLIOGRÁFICAS............................................................131

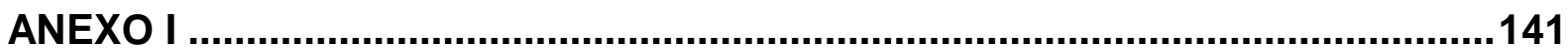




\section{INTRODUÇÃO}

\subsection{Justificativa}

A pavimentação representa parcela importante da economia dos países, uma vez que este patrimônio valoroso conecta uma rede que permite movimento de pessoas e cargas, essencial ao desenvolvimento. Desta forma, podem-se associar as riquezas de um país à sua malha rodoviária pavimentada, com qualidade de rolamento.

O cenário dos transportes revela que o Brasil, embora tenha tido um crescimento da malha pavimentada tardio em relação aos países desenvolvidos, tem apresentado crescimento médio de tráfego de veículos nas estradas de 3\% ao ano, chegando a $6 \%$ em algumas regiões. Apesar da ainda baixa porcentagem de rodovias pavimentadas no país, nos últimos anos o país voltou a apresentar um impulso tanto na ampliação da extensão de vias pavimentadas, como em duplicações e melhorias dos serviços de manutenção de forma geral.

Além do PAC, Programa de Aceleração do Crescimento, que nos últimos anos investiu de forma significativa nos serviços de pavimentação, a expansão da malha de rodovias de elevado volume de tráfego foi marcada pelo início do programa de concessões em 1994. As concessões de rodovias trouxeram uma nova etapa no desenvolvimento econômico e tecnológico do país.

A importância das rodovias pode ser explicada por sua participação na divisão modal do transporte de carga no país, onde o modo rodoviário responde por cerca de $58 \%$ do total (CNT, 2010).

O Brasil tem pouco mais de $12 \%$ da extensão total de suas rodovias pavimentadas (CNT, 2006), totalizando cerca de $219.000 \mathrm{~km}$, sendo mais que $1.400 .000 \mathrm{~km}$ de vias não pavimentadas. Para ilustração, os EUA, país de dimensões continentais como o nosso, têm por volta de $65 \%$ de suas rodovias pavimentadas, o que 
corresponde a aproximadamente $4.200 .000 \mathrm{~km}$, segundo a agência americana de inteligência (CIA, 2007). A disparidade brasileira é ainda maior se comparada a países como a França e a Suiça, com parcas dimensões territoriais, porém com extensa malha rodoviária. Alguns países europeus, como a Alemanha e a França, apesar de terem menores dimensões, apresentam consumo de asfalto maior que o brasileiro, pois possuem uma rede expressiva para manutenção, além de novas obras.

Novos desafios são lançados a este processo, especialmente no que tange aos impactos causados pela ocupação da terra e pelos métodos executivos de pavimentação, uma vez que a indústria da pavimentação responde como fonte poluidora em diferentes aspectos ambientais.

Muitos esforços têm sido envidados para o desenvolvimento de tecnologias com menor impacto ambiental e que não sacrifiquem a qualidade dos materiais empregados, tampouco os resultados de durabilidade esperados. Com vistas a estas dificuldades, os pavimentos deteriorados se tornaram fontes renováveis, considerados materiais de possível reciclagem e de maior valor econômico.

As pesquisas que avaliam a reutilização de materiais promovem maior valor técnico a eles e possibilitam a substituição de agregados virgens por agregados fresados. As pesquisas e a utilização dos materiais provenientes de pavimentos degradados se intensificaram na década de 1970, em função da crise econômica e de petróleo (Karlsson, 2006). O pavimento asfáltico fresado (em inglês, Reclaimed Asphalt Pavement - RAP) encontra ampla aplicabilidade na composição de diferentes misturas asfálticas, conforme se verifica na Figura 1. 


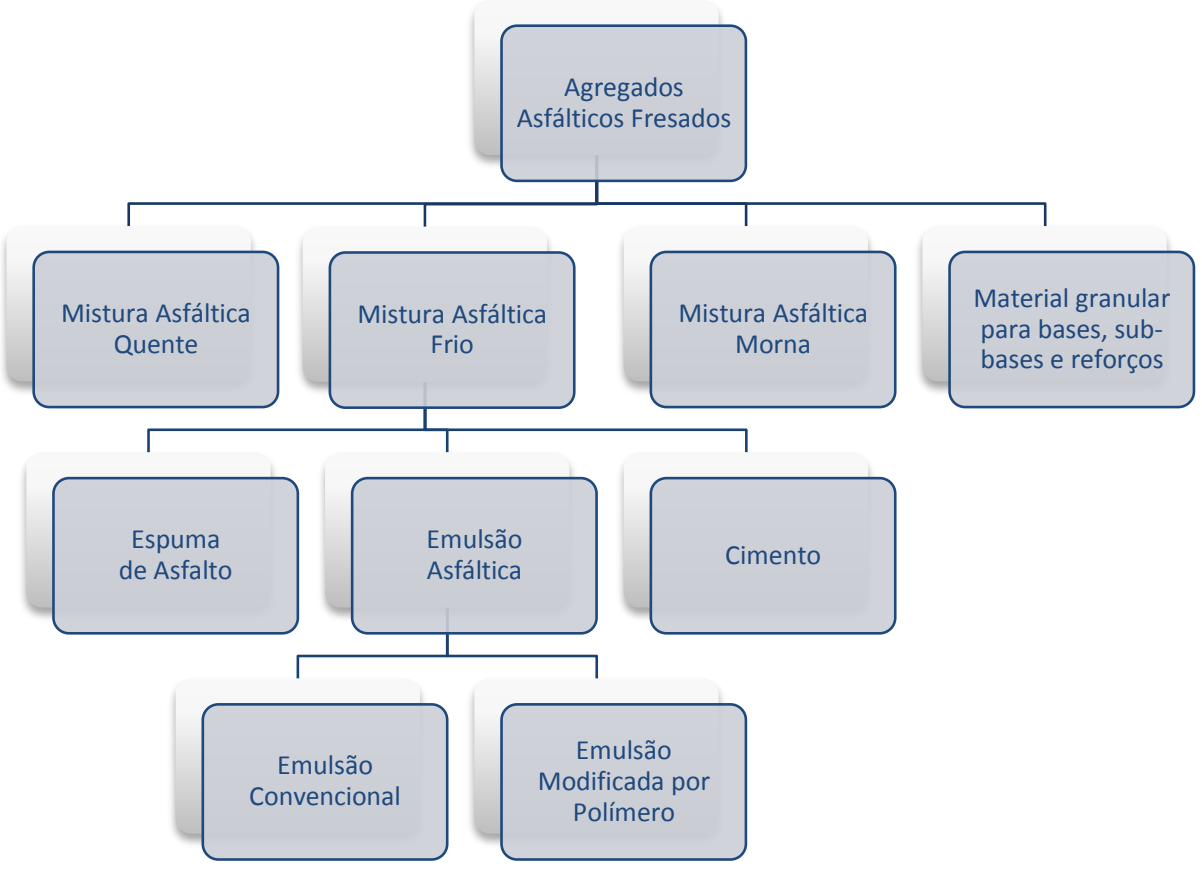

Figura 1 - Diferentes aplicações em misturas do agregado fresado.

Este panorama reflete a necessidade da reutilização de materiais e, por conseguinte, a necessidade de pesquisas de processos, de métodos e de produtos. As condições de aplicabilidade dependem de uma série de fatores que conduzem à adoção das diferentes soluções para a restauração. Dentre estes fatores encontramse: a disponibilidade de material, características dos pavimentos deteriorados candidatos à restauração, consagração de métodos de aplicação e fatores de impacto ambiental.

Desde que foi assinado o Protocolo de Kyoto em 1997, muitos países comprometeram-se em reduzir os impactos ambientais de suas atividades, forçando a incorporação de medidas sustentáveis e conduzindo a formulação de normatizações regionais de controle destes impactos. Dentre os principais objetos de exploração, para atender estas normas mais severas de proteção ambiental, estão os materiais recicláveis, provenientes de diversas fontes. Os pavimentos asfálticos envelhecidos figuram como fonte de materiais agregados valiosos que, dependendo de sua forma de re-uso, podem gerar vários benefícios, além de atender as metas de redução de impactos. 
Conforme pesquisa da ARRA (2001) a restauração dos pavimentos asfálticos é normalmente realizada através da adição de novas camadas asfálticas, com ou sem a retirada das camadas deterioradas. Os agregados usualmente utilizados na indústria da pavimentação são regularmente extraídos de pedreiras, iniciando um ciclo de produção e de transporte com profundos impactos ambientais, sem mencionar ainda os custos destes processos, que segundo o MnDOT (2000), são entre 50 e $60 \%$ maiores do que aqueles que contemplem algum tipo de reciclagem.

Os pavimentos envelhecidos, ora são recobertos por camadas sucessivas de materiais novos, ora são extraídos e conduzidos a destinações inadequadas. Contudo, a empregabilidade destes materiais tem aumentado com 0 desenvolvimento de novas técnicas de produção de misturas asfálticas.

Das técnicas de processamento de pavimentos asfálticos fresados, destaca-se neste trabalho a reciclagem a frio, método correspondente à utilização de material asfáltico fresado, extraído de vias deterioradas, com reprocessamento à temperatura ambiente, gerando novas misturas asfálticas capazes de suportar os esforços do tráfego e as variações climáticas.

A técnica de reciclagem a frio tem sido largamente utilizada como recurso para atingir metas de contenção do aquecimento global, justamente por apresentar uma série de benefícios diretamente associados. Entre os benefícios, Alkins, Lane et al. (2008) citam a otimização do uso de recursos naturais, redução no consumo de energia, redução na emissão de gases, menor emissão de poluentes, e, portanto, contribui para melhorias nas questões relativas à saúde, meio ambiente e prevenção de riscos. Existe grande dificuldade em contabilizar os benefícios ambientais e operacionais, apesar de evidentes; esses benefícios refletem-se na escolha por técnicas executivas mais eficientes que têm sido mais cogitadas por agências de transporte, empresas e concessões.

Esta pesquisa de reciclagem a frio de pavimentos asfálticos deteriorados vai de encontro às necessidades de desenvolvimento tecnológico sustentável e eficiente, realçado pela necessidade de destinação ao material envelhecido, e encontra ainda 
justificativa no desafio e urgência da reabilitação de pavimentos asfálticos em diversas rodovias brasileiras.

\subsection{Objetivo}

Este trabalho tem por objetivo avaliar o desempenho de camadas de pavimentos asfálticos deteriorados submetidos à técnica de reciclagem a frio in situ com emulsão modificada por polímero e com aditivos. O estudo foi conduzido por meio de testes laboratoriais destes materiais reciclados e de pesquisa de campo em pavimentos de trecho experimental executado com diferentes espessuras da camada reciclada, recobertas por diferentes tipos de camada de revestimento.

Para tanto, foram avaliados em laboratório os parâmetros de dosagem e as propriedades mecânicas de misturas recicladas com emulsão; em campo, foram avaliados os comportamentos funcional e estrutural dos pavimentos que constituem o trecho experimental desta pesquisa, composta por 9 segmentos construídos na Rodovia Régis Bittencourt, BR 116/SP, sob responsabilidade da Concessionária AutoPista Régis Bittencourt do Grupo OHL Brasil.

\subsection{Organização da Dissertação}

Capítulo 1 - Introdução

Apresenta uma perspectiva geral de como esta pesquisa se insere no contexto atual da pavimentação asfáltica e os objetivos do trabalho.

Capítulo 2 - Revisão Bibliográfica

Apresenta uma revisão bibliográfica sobre o tema, abordando um histórico de aplicação da reciclagem de pavimentos e fundamenta conceitos da produção em laboratório e em campo de misturas recicladas a frio.

Capítulo 3 - Ensaios de laboratório

São apresentados os ensaios realizados em laboratório, bem como seus resultados, e características relevantes ao avanço da pesquisa. São identificados os aspectos 
mais significativos para a calibração de resultados obtidos em campo e em laboratório.

Capítulo 4 - Experimento de Campo - Rodovia Régis Bittencourt Aborda os principais aspectos relacionados à construção do trecho experimental, bem como a análise das diversas características encontradas antes do processo de reciclagem.

Capítulo 5 - Monitoramento de Desempenho do Trecho Experimental Apresenta os dados obtidos no monitoramento do trecho experimental antes e depois da restauração por meio de reciclagem, os ensaios laboratoriais com amostras de pista, e análise dos resultados de maneira a avaliar os benefícios da reciclagem a frio.

Capítulo 6 - Conclusões e Recomendações 


\section{REVISÃO BIBLIOGRÁFICA}

\subsection{Reciclagem de pavimentos}

Reciclar pavimentos é reaproveitar os materiais desgastados e extraídos por meio de fresagem, sendo aplicados em uma nova composição de modo a restaurá-lo. De acordo com Bernucci et al (2007), reciclar significa reutilizar misturas asfálticas envelhecidas para produção de novas misturas, aproveitando os agregados e ligantes remanescentes.

A restauração por meio de reciclagem configura o reaproveitamento total ou parcial de camada existente, submetido a processo de mistura em equipamento apropriado, compondo uma nova mistura homogênea, juntamente com a adição de novos elementos, com o objetivo de reaplicação de camada destinada a resistir aos esforços do tráfego e condições ambientais.

O processo de reciclagem se iniciou na Alemanha com materiais britados a mão; há registros históricos de aplicação da reciclagem já em 1923 em Singapura (Wood, 1978). Segundo Pinto (1989), a evolução nas máquinas fresadoras no estado americano da Califórnia propiciou a reciclagem de modo mais eficiente. Apesar de registros de aplicação no Brasil datarem da década de 1960, a pesquisa sobre a reciclagem de pavimentos é tecnicamente ainda pouco conhecida no país.

O material fresado pode ser incorporado em diferentes tipos de misturas betuminosas, com variações no teor de utilização, usualmente entre $10 \%$ e 30\% em alguns países (Martínez, 2010). Nas misturas recicladas, os materiais fresados são os elementos principais, sendo empregados diferentes teores, podendo ser integralmente compostas por material fresado, sem qualquer adição de material virgem (ARRA, 2001). A dosagem das misturas deve determinar estas proporções, de modo a alcançar desempenho satisfatório na situação prevista no projeto.

Dentre os principais benefícios técnicos da reciclagem, segundo (Castro Neto, 2000), cita-se sua utilização em casos onde houve necessidade de manutenção de 
greide como obras de arte, onde se exigiu fresagem, sem que o material seja utilizado neste mesmo pavimento; possibilidade de correção em pistas com diversas faixas de rolamento que apresentam condições estruturais diferenciadas entre si e que exigem reparos distintos.

O beneficiamento do material asfáltico fresado no processo de reciclagem pode ocorrer simplificadamente de duas formas: a quente ou a frio e varia ainda em função da área de produção, sendo possível ser realizado em usinas estacionárias, usinas móveis, ou in situ, cada qual com vantagens e desvantagens específicas (Castro, 2003).

A alocação desta camada na estrutura deve ser avaliada em função das condições de contorno (Suzuki, 2005). Devido ao elevado volume de vazios das misturas recicladas a frio, estas devem receber camada selante que impede o acesso da água a camada reciclada. Este, portanto não deve ser considerado um pavimento drenante de modo que aspectos concernentes à drenagem e continuidade hidráulica das camadas subjacentes devem ser avaliados criteriosamente.

A primeira etapa do processo de reciclagem constitui-se na obtenção do material proveniente de pavimentos deteriorados. $O$ processo de fresagem consiste na extração do material do pavimento envelhecido da pista com utilização de máquina fresadora, que desbasta o pavimento em profundidades adequadas, especificadas em projeto (FHWA, 1997).

Segundo o DER (2006), a fresagem pode ocorrer em temperatura ambiente (a frio) ou com aquecimento do pavimento (a quente), sendo que a temperatura é primordialmente definida pelo equipamento disponível e pelo tipo de tratamento que se pretende dar ao material extraído. Independente do método de fresagem, o material deve ser reduzido às dimensões máximas de acordo com a faixa granulométrica de trabalho do projeto em que será aplicado. Caso o processo de fresagem não seja suficiente para reduzir o material às dimensões desejadas, são utilizados equipamentos de britagem simplificados. 
O agregado fresado é constituído por grumos de agregados cobertos ou parcialmente recobertos por asfalto envelhecido a eles aderido, o que confere características bastante peculiares devido à sua composição. De acordo com ARRA (2001) existem três vertentes de definição deste material: (i) considerado agregado negro, onde o agregado fresado é tratado como um agregado e o ligante oxidado presente nos grumos não é considerado na dosagem; (ii) o asfalto aderido é passível de regeneração até a consistência original ou próxima a ela, por incorporação de agentes rejuvenescedores e, por fim, a mais aceita (iii) relativo grau de amolecimento do asfalto, de difícil mensuração, mas que interfere no resultado de ensaios de comportamento mecânico. De acordo com Motta e Leite (2002), a recuperação do ligante envelhecido por meio de misturas a frio é questionável, desta forma optou-se por adotar nesta pesquisa a definição de agregado negro, assim definido pela ARRA (2001) também adotada pelo DNIT (2006).

Uma extensa lista de defeitos pode ser corrigida ou mitigada com a aplicação da técnica de reciclagem, segundo o MnDOT (2000), sendo o principal deles a redução significativa da reflexão de trincas por envelhecimento, já que este é um importante e comum defeito em pavimentos. A reciclagem corrige também defeitos como desagregação de origem não estrutural, deformação permanente de misturas asfálticas por problemas de dosagem, corrugação, escorregamento, defeitos de superfície e exsudação. Rogge e Hicks (1993) indicam a reciclagem para pavimentos com recapeamentos sucessivos, problemas de drenagem, insuficiência de agregados na região, ou problemas de alinhamento vertical e horizontal.

Defeitos atribuídos às questões estruturais em camadas subjacentes exigem intervenção nas camadas que apresentam problemas, ciente de que a ausência de soluções para essas camadas subjacentes implica no retorno dos defeitos, uma vez que o tratamento restrito a camadas de revestimento não resolve a origem dos problemas (Karlsson, 2006). A investigação da natureza dos defeitos, antes da intervenção, pode direcionar acertadamente a técnica para restauração, resultando em pavimentos mais duráveis com condições adequadas de trafegabilidade e consequentemente resulta em economia dos recursos materiais disponíveis. 
A reciclagem oferece materiais e métodos construtivos com variações em relação a técnicas tradicionais, exigindo estudos, ensaios, equipamentos e adaptações adequados.

\subsection{Resíduos Sólidos Provenientes da Pavimentação}

A gestão de resíduos sólidos é um problema de grande proporção, agravado pela expansão das cidades. Além do espaço físico exigido pelo grande volume de resíduos, existe a preocupação com a contaminação do meio ambiente, incluindo contaminação do solo e contaminação de lençol freático por metais pesados, entre outros. O resíduo de construção civil representa parcela significativa neste cenário, incluindo nesta denominação o resíduo proveniente da pavimentação.

Os resíduos são identificados conforme sua fonte geradora, seus constituintes e suas características, resultando nas três classes distintas: I - perigosos (subdivididos entre características de Inflamabilidade, Corrosividade, Reatividade, Toxicidade), II - não inertes, III - inertes - de acordo com a ABNT NBR 10004/2004 - Resíduos Sólidos. A caracterização do material dentro destas classes é definida por medidas baseadas em especificações, como a norma americana (ASTM-D93). Países europeus possuem mais testes e maior diversidade de fatores para avaliar o potencial risco dos materiais comparado com os norte-americanos (FHWA, 2000).

No Brasil, a Resolução № 05 - Gestão de Resíduos e Produtos Perigosos do CONAMA (Conselho Nacional do Meio Ambiente) deliberou sobre os resíduos classificados de acordo com a ABNT NBR 10004 (de 1987, substituída em 2004), e definiu o Plano de Gerenciamento de Resíduos Sólidos, o Sistema de Tratamento de Resíduos Sólidos e o Sistema de Disposição Final de Resíduos Sólidos. Estes itens integram processos de licenciamento ambiental. Contudo, não existem regulamentações nacionais nem abrangentes e nem específicas para a destinação de resíduos sólidos de construção civil, de tal forma que o artigo 14 desta resolução estipula que, considerado o material inerte, e resguardadas as condições de proteção do meio ambiente, estes resíduos sólidos devem receber tratamento e disposição final semelhante aos resíduos domiciliares. 
A Lei Federal brasileira 9.985/2000 dá providências de proteção ao meio ambiente, sem definir aspectos concernentes aos resíduos sólidos de pavimentação. Regulamentações municipais tendem a especificar volume de material disposto, taxando o tipo de tratamento e utilização dos espaços definidos como destino final. A Agência de Proteção do Meio Ambiente norte-americana (EPA), regula os aspectos relativos ao manejo dos materiais rejeitados.

A Prefeitura do Município de São Paulo (PMSP) dispõe de lei específica (Lei № $14.015 / 2005)$ para o descarte de misturas asfálticas retiradas dos pavimentos, onde é exigida: (i) a apresentação de plano de manejo ambiental, que impede "descarte em qualquer tipo de bota-fora, descarte em aterro sanitário, descarte em terrenos públicos ou privados não credenciados para tal finalidade, remoção para áreas externas aos limites geográficos do Município de São Paulo", ou (ii) a reciclagem preferencialmente em pavimentação no próprio município.

Países em processo mais avançado de pesquisa e aplicação de reciclagem definiram condições para a aplicação da reciclagem de pavimentos deteriorados, segundo Piarc (2008). O Japão possui Lei de Construção com Materiais Reciclados; - Canadá aplica tarifas muito elevadas para o desperdício de material, estimulando a reciclagem em função dos custos menores; a Austrália taxa significativamente o uso dos aterros para depósito final; a Alemanha recicla 100\% do material extraído de pista com especificações em leis e manuais de construção sustentável; a Inglaterra e a Suíça aplicam altas taxas no uso de aterros e/ou proíbem uso de aterros para materiais que podem ser reutilizados, sendo que a Suiça recicla $100 \%$ do material asfáltico envelhecido (FHWA, 2000). Alguns países aumentam também a taxação sobre agregados virgens como incentivo à reciclagem.

A Alemanha iniciou sua conduta efetiva sobre materiais recicláveis em 1986, estabelecendo a seguinte ordem prioritária: evitar a geração do resíduo, reciclar os resíduos, disposição final de resíduos como última alternativa. Atualmente, a política de tratamento de resíduos alemã influencia toda a comunidade européia (FHWA, 2000). 
O desenvolvimento de procedimento para aproveitamento e gerenciamento destes resíduos é fundamental para viabilizar reutilização apropriada com desempenho satisfatório e incrementar a vida útil dos aterros que recebem os rejeitos.

\subsection{Técnicas de Reciclagem de Pavimentos Asfálticos - Internacionais}

A Asphalt Recycling \& Reclaming Association (ARRA, 2001), associação norteamericana, subdivide a reciclagem de pavimentos asfálticos em cinco categorias de execução: reciclagem a quente (em usina e in situ), reciclagem a frio (em usina e in situ) e reciclagem profunda do pavimento; adicionalmente, a reciclagem morna é encontrada frequente e mais recente na literatura (Figura 2). Cada método de execução provê características diferentes de modo a se adaptar a técnica ao pavimento candidato à restauração.

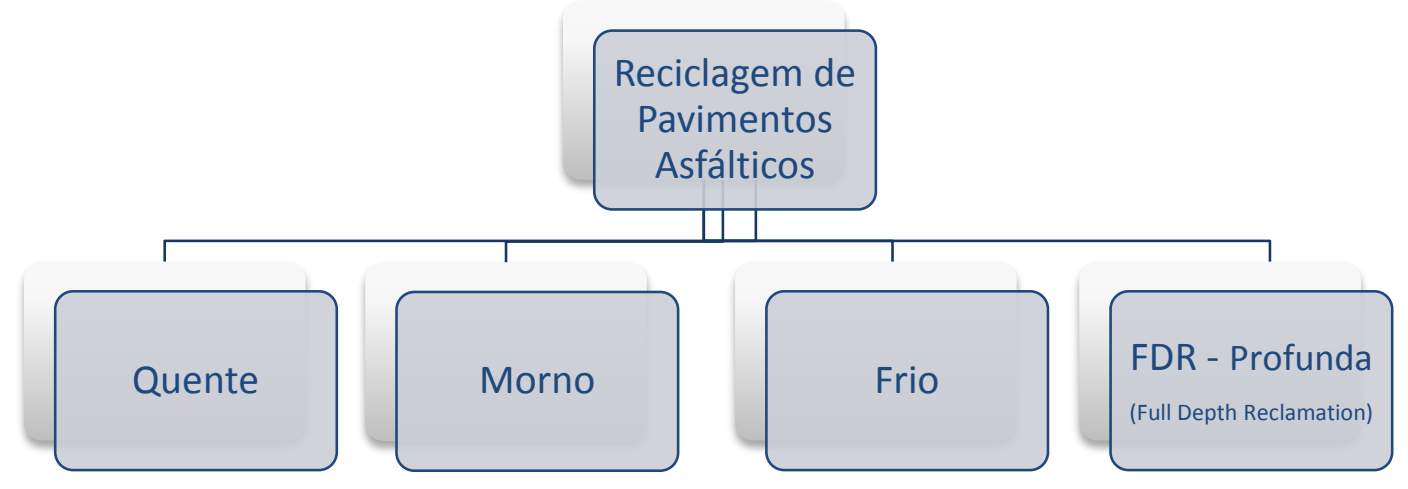

Figura 2 - Técnicas de reciclagem de pavimentos asfálticos

As técnicas norte-americanas não variam significativamente das empregadas na comunidade européia, que restaura seus pavimentos por meio de reciclagem, com maior frequência que os Estados Unidos, respeitadas as devidas proporções (FHWA, 2000).

A reciclagem a quente em usina assemelha-se em alto grau com a produção de misturas a quente convencionais, tanto que as usinas utilizadas são as mesmas (tipo gravimétrica ou volumétrica), com poucas adaptações, de acordo com o manual de reciclagem de pavimentos da FHWA (1997). Os agregados fresados extraídos de pista são transportados até a usina onde são aquecidos e adicionados à mistura que 
pode ou não conter agregados virgens (também adequadamente aquecidos). Contudo, Mallick, et al (2007) recomendam que o agregado fresado não seja exposto a altas temperaturas capazes de causar deterioração adicional ao material. A mistura é distribuída na pista e compactada também de modo similar ao concreto betuminoso usinado a quente.

Reciclagem a quente in situ é uma técnica relativamente simples que depende de equipamentos específicos e que atendam a um grande volume de material do pavimento a ser restaurado. Existem três procedimentos distintos de aplicação da técnica: escarificação com aquecimento, onde o pavimento é seqüencialmente aquecido, escarificado, rejuvenescido, nivelado, reperfilado e compactado; repavimentação, que segue o mesmo princípio da escarificação, somando-se ainda uma nova camada delgada de mistura asfáltica sobre a superfície reciclada; remixing, novamente similar aos anteriores, porém com maiores temperaturas que permitam a adoção de revestimento a reciclar mais espesso e ainda permitam correções na granulometria do material ou ajustes nas propriedades do ligante do material envelhecido (FHWA, 1997).

A incorporação de agregados fresados em misturas mornas tem sido realizada com cautela, segundo Tao e Mallick (2009); elevadas taxas de agregados fresados em misturas asfálticas reduzem a trabalhabilidade das misturas quentes e mornas, contudo a inclusão de aditivos apropriados permite que à temperatura mais baixa (aproximadamente $125^{\circ} \mathrm{C}$ ), os grumos de asfalto envelhecido aderidos aos agregados fresados, não afetem a trabalhabilidade e compactação da mistura morna, que recebe aditivos para alterar a trabalhabilidade e viscosidade. As usinas exigem adaptação para produção de misturas mornas, com ou sem adição de agregados fresados.

A reciclagem profunda (FDR - Full Depth Reclamation) permite que mais camadas, maiores espessuras, sejam contempladas pelo processo, desde que inseridas nos parâmetros do projeto (ARRA, 2009). Esta técnica comporta processos de estabilização e regularização de camadas de base e sub-base e ainda a alteração nas espessuras das camadas constituintes do pavimento, ampliando a capacidade da reciclagem quando existem deficiências estruturais envolvidas (Better Roads, 
2001). O conhecimento das espessuras dos pavimentos é fundamental para o sucesso da técnica.

Reciclagem a frio em usina representa principalmente uma alternativa para situações onde o equipamento de reciclagem a frio in situ não é comportado pelas vias, devido às suas dimensões. Representa ainda opção em situações onde as misturas recicladas a quente apresentam perda de temperatura considerável no transporte entre usina e obra distantes, uma vez que a mistura a frio é aplicada em temperatura ambiente (Castro, 2003). Também funciona como alternativa a produção de misturas mais elaboradas que incorporem agregados virgens que necessitem de tratamento especial, dificilmente contemplado por equipamentos in situ. Ainda segundo Castro (2003), a usina tem funcionamento relativamente simples, similar às usinas de solos, contudo necessita de adaptações para atender às condições especiais.

A reciclagem a frio pode ainda ser realizada com apoio de usinas móveis, sistema similar às usinas estacionárias montados nas proximidades dos trechos em execução, que permitem trabalho com misturas a frio. Segundo Pinto (2002), estes equipamentos trabalham por meio de geradores, permitindo independência da rede pública de energia; de acordo com o mesmo autor, esse processo pode produzir misturas de alta qualidade.

Reciclagem a frio in situ é um processo que leva equipamentos para a pista a ser restaurada e utiliza os materiais extraídos neste mesmo local, em uma nova mistura dosada e executada concomitantemente, numa seqüência que se inicia com a fresagem dos pavimentos deteriorados e finaliza com a disposição em pista da mistura reciclada (Liberatori et al., 2005). A reciclagem in situ depende da disponibilidade de equipamentos no mercado que sejam adequados a este fim. Esta técnica apresenta muitas vantagens que serão adequadamente descritas no item 2.5 .

As especificações mais detalhadas dos processos de reciclagem dependem de uma série de condições, de modo que as soluções são regionalizadas variando principalmente em função das características dos pavimentos, tipo de equipamento 
disponível, restrições e necessidades dos projetos de reparo, além de amparo governamental (legislação e manuais). Como resultado deste cenário, não há nenhum método de reciclagem a frio consagrado e integralmente aceito (ARRA, 2001).

Diante do objetivo desta pesquisa, que avalia a reciclagem a frio "in situ" como técnica de restauração de pavimentos, são elencados a seguir os mais relevantes métodos de dosagem de misturas recicladas a frio, desenvolvidos nos EUA e Canadá, de acordo com a publicação do Departamento de Transporte de Minnesota (MnDOT): AASHTO, USACE, Califórnia (CaDOT), Oregon (ODOT), Pennsylvania (PaDOT) e Ministry of Tranportation of Ontário. Os critérios adotados por estas agências foram utilizados para a elaboração do Local Research Board, cujas diretrizes asseguram que o sucesso da reciclagem a frio in situ está diretamente associado: (i) à correta avaliação do pavimento candidato, (ii) ao desenvolvimento de misturas em laboratório e (iii) às especificações de construção, cientes de estarem incluídos nestas três categorias uma série de fatores significativos (Mn/DOT, 2000).

\subsection{Técnicas de Reciclagem de Pavimentos Asfálticos - Nacionais}

A expansão dos números de projetos de reciclagem de pavimentos no país deve-se especialmente à disponibilidade e à modernização de equipamentos específicos (DNIT, 2006). As técnicas aplicadas correspondem similarmente à experiência internacional. $\mathrm{O}$ processo de reciclagem regularmente necessita de adaptação às condições de contorno; a transferência de métodos ocorre muitas vezes de maneira simplista, com a aplicação de métodos e técnicas novas sem os devidos estudos para a sua nacionalização ou adaptação às condicionantes locais de clima, de tráfego e de materiais. Esta prática leva muitas vezes a interpretações equivocadas, ou uso de técnicas não aplicáveis às nossas condições.

As técnicas utilizadas no Brasil são as mesmas citadas no item 2.3, reciclagem a quente em usina, reciclagem a frio em usina (móvel e estacionária), reciclagem a quente in situ, reciclagem a frio in situ e reciclagem profunda do pavimento. Estas 
técnicas são aplicadas para uso da reciclagem como camada de base e como camada de rolamento (DNIT, 2006) ${ }^{2}$.

Tendo em vista os objetivos desta pesquisa, são descritas algumas técnicas de reciclagem a frio utilizadas no país com uso de: (i) espuma de asfalto, (ii) cimento Portland ou (iii) emulsão asfáltica (Castro, 2003).

A espuma de asfalto é uma das técnicas que empregam o cimento asfáltico de petróleo aquecido a temperaturas entre $160^{\circ} \mathrm{C}$ e $180^{\circ} \mathrm{C}$ e misturado à água (em torno de $3 \%$ em massa) em temperatura ambiente numa câmara de expansão, alterando a condição do asfalto líquido para espuma, permitindo que este seja misturado com agregados frios e úmidos sem interferir no seu desempenho (Dama, 2003). Após o processo de obtenção da espuma, o material tem suas propriedades baseadas na taxa de expansão e meia-vida, que definem, respectivamente, a trabalhabilidade e a capacidade de recobrimento, estabilidade e tempo disponível para mistura (Castro, 2003). A reciclagem com espuma de asfalto exige equipamento apropriado para obtenção da espuma, inserido no trem de reciclagem juntamente aos demais equipamentos.

A reciclagem com Cimento Portland apresenta algumas vantagens associadas à disponibilidade do material, conhecimento de suas características e aceitabilidade pelo mercado. O processo inicia-se com a fresagem do material, seguido pela distribuição de cimento Portland sobre os agregados fresados, distribuição de água e finalmente a misturação e homogeneização por meio de recicladora específica (Gusmão, 2008). Camadas cimentícias, inclusive a reciclagem com cimento podem apresentar problemas devido à elevada rigidez da camada, trincamento por retração, além de problemas associados à cura, sendo fundamental a consideração destes fatores, principalmente para elevados teores de cimento.

A reciclagem com emulsão asfáltica é relativamente simples em relação às formas que utilizam cimento ou espuma de asfalto, uma vez que o fornecimento de emulsão ocorre por meio de caminhão tanque, e os controles necessários são similares aos adotados em execuções de pré misturados a frio com emulsão. 
Outros agentes podem ser adicionados para aperfeiçoar as características das misturas, tais como agentes de reciclagem e melhoradores de adesividade. A escolha pelo ligante dá-se em função das características da mistura principalmente pelas características dos equipamentos envolvidos no processo de misturação (Wirtgen, 2004).

A definição por técnicas e materiais, conforme mencionado anteriormente deve seguir uma série de considerações balizadoras. A principal defasagem no país refere-se à avaliação objetiva e imparcial de estruturas recicladas, capazes de nortear a implantação de procedimentos e normas pelos órgãos responsáveis. Volume de tráfego, histórico preciso de construção e restaurações da pista, características (espessura, módulo de resiliência e condição de integridade) das camadas, presença de misturas especiais, presença de geotêxteis, condições estruturais, causas de falência, são informações primordiais para a seleção da técnica e do projeto (ARRA, 2001). Equações de desempenho, número estrutural e método de dimensionamento de reforço são parâmetros ainda sem especificação, o que acaba por conduzir a erros e medidas individuais de procedimentos (Motta, 2002).

\subsection{Reciclagem de Pavimentos a Frio in situ com Emulsão}

Composto por etapas específicas, este processo apresenta muitas vantagens, especialmente se comparado a métodos convencionais de restauração. Reciclar a frio significa trabalhar com a mistura em temperatura ambiente, de tal forma que todos os materiais envolvidos no processo permitam trabalhabilidade nesta temperatura.

A sequência de itens para a reciclagem a frio in situ deve ser, a extração do pavimento deteriorado por meio de fresagem (incluindo adição de água), a seleção granulométrica do agregado fresado, a adição de ligante asfáltico, misturação, distribuição em pista, e compactação (ARRA, 2001). Os equipamentos para atingir estas metas geralmente estão dispostos nesta mesma sequência, e podem estar ou não conectados, formando o trem de reciclagem (Murphy e Emery, 1996). 
O processo se inicia então, com a fresagem de material a frio que consiste na rotação de um cilindro composto por "bits" ou dentes de corte capazes de desbastar o pavimento por abrasão, em temperatura ambiente, sem necessidade de aquecer o pavimento evitando, por conseguinte, o dispêndio de energia (DER, 2006). Durante a execução ocorre um aquecimento natural pelo impacto dos dentes de corte no pavimento, no entanto o cilindro é constantemente resfriado pelo teor de água lançado no pavimento durante o processo de fresagem (Bonfim, 1999). A água adicionada diminui a produção de pó, reduzindo a poluição atmosférica.

Se for necessária a adição de agregados virgens, estes são distribuídos na pista antes da fresagem e processados pela fresagem juntamente com o pavimento envelhecido (DNER, 2000); o mesmo ocorre com a adição de fíler. O processo realizado a frio utiliza imediatamente o material retirado, desobrigando a implantação de canteiros de obras em áreas lindeiras, atenuando o conflito gerado nas ocupações adjacentes.

O material é conduzido à etapa de seleção granulométrica, que limita o diâmetro nominal máximo; os agregados rejeitados podem ser re-britados e inseridos no processo novamente, possibilitando aproveitamento total dos materiais. De acordo com DER (2006), o equipamento para a re-britagem deve configurar parte da unidade recicladora.

A baixa variabilidade dos agregados obtidos por fresagem da pista é muito importante para o sucesso da reciclagem, por esta razão os trechos restaurados devem ser selecionados para garantir a máxima homogeneidade. A reciclagem in situ contribui neste sentido, pois não necessita de armazenamento dos materiais. $A$ separação em estoques exige maiores controles de tal forma que estas características variáveis dos agregados influenciem minimamente nas misturas recicladas (Karlsson, 2006).

Como resultado da velocidade em que o trem de reciclagem trabalha, podem-se encontrar diferentes faixas granulométricas do material. Segundo observado por Bonfim (1999), as velocidades mais elevadas resultam em faixas com menos agregado miúdo e mais porcentagem de graúdos, enquanto a velocidades mais 
baixas de operação da fresadora, apresenta granulometria com diminuição do agregado graúdo. Também foi constatado que a velocidade deve ser constante para garantir que a faixa granulométrica esteja dentro da especificada em projeto. Um fator importante com relação à velocidade, também segundo Bonfim, é que esta varia em função da espessura de corte, das condições do pavimento, dentre outros fatores que apenas serão ponderados no momento da execução.

Após a fresagem do pavimento deteriorado, é indicado realizar trabalho de imprimação antes da camada reciclada; pode-se dispor de equipamento capaz de espargir o ligante asfáltico (DER, 2006). Este dispositivo pode estar inserido no equipamento principal, ou ser incrementado posteriormente.

Uma vez selecionados os materiais agregados, este são conduzidos ao tanque de misturação, dotado de controle de vazão de ligante asfáltico, adicionado em função da porcentagem em peso dos agregados. Deve-se considerar também que na reciclagem a frio com uso de emulsão a temperatura de execução é influenciada pela temperatura ambiente, podendo representar problemas em regiões muito frias ou muito quentes (Salomon, 2008). Em seguida, a mistura é lançada na unidade acabadora, responsável pela distribuição homogênea na pista. A mistura é compactada posteriormente por rolo pneumático e rolo chapa.

A mistura a frio permite rápida abertura ao tráfego, precedida do salgamento da pista, quando verificadas condições do pavimento suportar as tensões de carregamento do tráfego. Em estudo comparativo entre emulsão e espuma, o comportamento das misturas com emulsão mostrou maior coesão poucas horas após a misturação, permitindo rápida abertura ao tráfego, sem danos ao pavimento recém restaurado (Kim et al., 2004).

Quando a concepção do projeto prevê execução de camada de cobertura da camada reciclada, é necessário considerar o tempo de cura da reciclagem. De acordo com MnDOT (2000), este período varia entre sete e quatorze dias. O controle de evolução de resistência em relação à cura pode ser feito por meio de ensaios não destrutivos, como FWD (Falling Weigth Deflectometer), que permite identificar 
valores de módulo de resiliência através de retroanálise, importante critério no processo de cura (Loizos, 2008).

Alguns benefícios associados à execução da reciclagem a frio in situ com emulsão são elencados a seguir: alta produtividade; economia de reservas naturais de agregados; redução na emissão de gases; despensa do transporte de materiais agregados entre fonte e obra (reduzindo desgaste das vias de acesso e desobrigando a existência de pontos de armazenamento e de produção de material), destino adequado aos agregados provenientes de pavimentos envelhecidos e ainda melhorias indiretas como, acessibilidade e desenvolvimento das regiões vizinhas às vias restauradas.

O processo de reciclagem, conforme Wirtgen (2004) deve avaliar os dados referentes a fatores como a natureza e composição do pavimento existente, o tipo e a extensão do desgaste a que ele esteve sujeito e ainda qual a finalidade da restauração. O objetivo é compreender de que forma se dará o comportamento do novo material quando aplicado, conhecendo as condições sob as quais ele estará em uso.

As etapas que integram o processo de reciclagem têm relação direta com a durabilidade da mistura. Apesar de esperadas reduções nos custos de construção de camadas recicladas (FHWA, 1997), estas têm capacidade para reduzir drasticamente a vida útil do pavimento quando materiais e métodos disformes são empregados. Castro Neto (2000) explica que é possível mensurar o impacto deste tipo de reabilitação comparando-se durabilidade e investimento financeiro, de modo a avaliar se o valor é viável em relação ao desempenho em campo.

A variabilidade do material extraído da pista impacta nas características da mistura reciclada, exercendo influência no desempenho do pavimento. Tendo isto em vista, a dosagem da mistura precisa corrigir eventuais defasagens em termos de comportamento do material; estas considerações são realizadas a partir da avaliação do comportamento destas misturas em laboratório. Os métodos de dosagem em laboratório devem ser estruturados para corresponder ao máximo às 
condições reais de aplicação. A aplicação em campo da camada reciclada deve ser especificada a fim de atender os valores referenciados de indicativos de desempenho. Ajustes em campo podem ser posteriormente necessários (ARRA, 2001).

\subsubsection{Agregados Fresados}

Conforme já mencionado, a extração do material envelhecido e sua configuração como material agregado pode ser realizada por fresagem a frio ou fresagem a quente. Segundo Piarc (2008), a principal diferença entre a fresagem a quente e a fresagem a frio está na faixa granulométrica obtida após o processo, isso porque o processo a quente, embora possa envelhecer o ligante, mantém a faixa idêntica à aplicada no pavimento envelhecido (devido à escarificação do pavimento), ao passo que o processo a frio fratura o material, gerando nova faixa granulométrica, independente da faixa do pavimento envelhecido, mas dependente de fatores como velocidade de avanço, condições de coesão da mistura e características do equipamento fresador. É necessário considerar que as características dos agregados reciclados são variáveis.

A caracterização do material agregado presente no processo de reciclagem deve considerar não apenas as dimensões dos grãos, mas também a presença de grumos e de ligante asfáltico envelhecido, determinando seu potencial dentro da nova mistura asfáltica (MnDOT, 2009). Quanto às dimensões máximas, o processo de reciclagem deve limitar o diâmetro nominal máximo passante, critério fundamental para a espessura da camada. Para que não ocorra perda do material rejeitado acima do diâmetro máximo, é importante que o equipamento possua britador acoplado ou associado.

A adição de material virgem pode ser utilizada para a correção ou a alteração na faixa granulométrica de modo a acrescentar intertravamento, melhorando o comportamento em relação à resistência. Algumas instituições limitam a taxa de uso de agregado reciclado, em função de resultados insuficientes para subsidiar essa escolha, supondo deficiência nas misturas pelo uso deste material (Thomas e 
Kadrmas, 2003). Existe certa incredulidade no comportamento das misturas que utilizam materiais reciclados, imaginando-se que o uso de agregados virgens produza misturas mais resistentes, contudo existem vertentes de pesquisa que assumem que as misturas compostas por materiais reciclados podem apresentar desempenho melhor que as misturas convencionais.

Os materiais obtidos pelo processo de fresagem apresentam geralmente forma cúbica, especialmente pela fresagem a frio. A fratura que este tipo de operação propicia é parecida com a extração de matérias em jazidas (Bonfim, 1999).

\subsubsection{Emulsão Asfáltica}

Hunter (1994) afirma que o asfalto é uma solução de complexa estrutura química composta por partículas de asfaltenos dispersas em maltenos e imersas em resina. Como resultado do comportamento dos diversos componentes químicos, sobre os quais apenas alguns apresentam carga superficial, a associação entre todas as partículas conduz a uma elevada resistência e promove viscosidade ao material. Simplificadamente, a alta proporção de asfaltenos e a baixa concentração de óleos geram um tipo de asfalto mais viscoso. A perda de viscosidade, que torna o asfalto menos resistente é resultado de movimentos individuais das partículas sob temperaturas mais altas.

Emulsão asfáltica é uma dispersão estável de dois líquidos imiscíveis, produzida a partir de quatro componentes essenciais: cimento asfáltico de petróleo, água (líquidos imiscíveis), agente emulsificante e energia mecânica de misturação, gerando um produto estabilizado quimicamente.

As formulações químicas das emulsões asfálticas são decisivas na indicação de uso e representa grande impacto nas propriedades físicas e no desempenho das misturas em que estas serão utilizadas; assim houve grande avanço nos últimos 20 anos no desenvolvimento de produtos e normas para atender atuais exigências nas propriedades das emulsões (James, 2006). 
Dentre algumas vantagens na utilização de emulsões asfálticas encontram-se o manuseio e aplicação em temperatura ambiente, fácil armazenamento e distribuição, redução no risco de oxidação por superaquecimento do ligante, diluição em água, ampliação do tempo de aplicação do material em campo, versatilidade de aplicações, além dos benefícios ambientais.

O asfalto utilizado na produção de emulsões representa entre $55 \%$ e $70 \%$ das emulsões, sendo utilizados preferencialmente os asfaltos mais moles (maior penetração) segundo a ABEDA (2001).

Os agentes emulsificantes são formações químicas com capacidade de reduzir a tensão superficial e permitir que os glóbulos de água e asfalto permaneçam em suspensão por um tempo; o agente emulsificante exerce grande influência nas características das emulsões, sendo responsáveis por facilitar a dispersão e manter estabilidade, impedindo a aglomeração dos glóbulos de asfalto, conforme se verifica na Figura 3 (James, 2006). As emulsões podem ser dos tipos direta ou indireta, porém essa formação não influencia no seu desempenho.

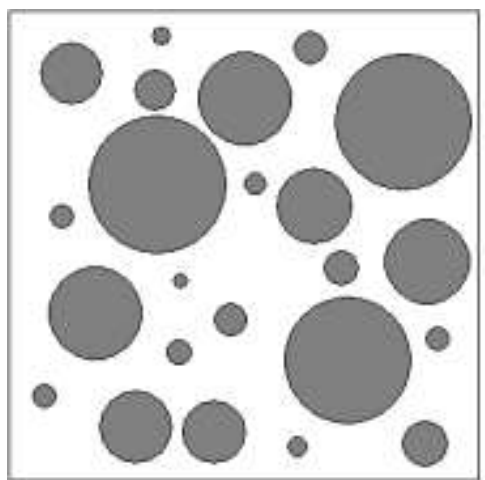

Glóbulos Dispersos

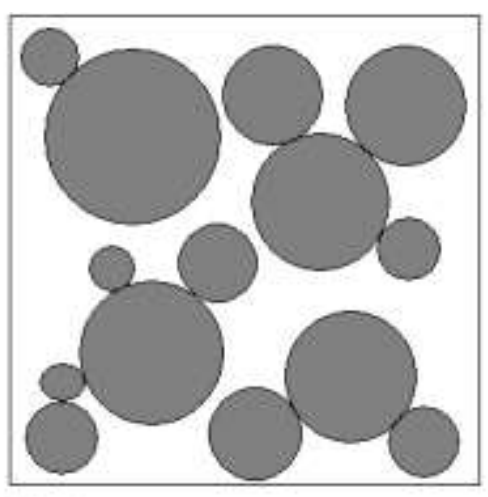

Floculaçã̃o

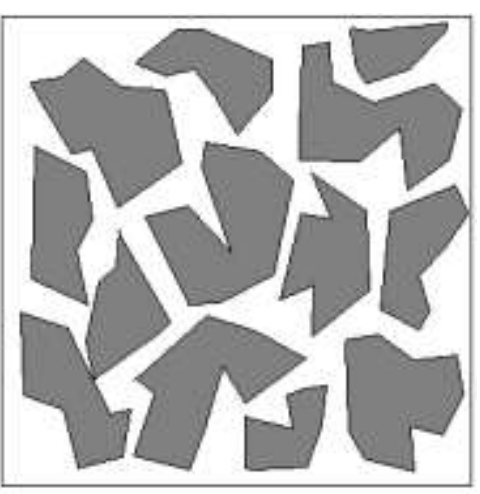

Coalescência

Figura 3 - Estrutura das emulsões asfálticas em diferentes estágios (Modificado a partir de Clerman, 2006)

Os agentes emulsificantes fornecem a carga à emulsão, determinando sua classificação, que pode ser catiônica, indicada pela letra C (carga positiva), aniônica (carga negativa) e não-iônica (pouco utilizada). Emulsões catiônicas são largamente utilizadas, representando $90 \%$ do uso de emulsões em todo o mundo. No Brasil, as emulsões catiônicas são predominantemente produzidas e comercializadas 
(ABEDA, 2001), pois apresentam maior compatibilidade com agregados de origens geológicas diversas, ao passo que as emulsões aniônicas têm algumas restrições (Academy, 2009).

As emulsões são ainda categorizadas em função do tempo de ruptura, processo onde ocorre desestabilização nas reações químicas e nos processos físicos envolvidos, no qual a emulsão sofre ionização pelo agregado mineral gerando o fenômeno de separação das fases. Neste período ocorre a formação do filme asfáltico contínuo sobre os agregados. A ruptura pode ser tipo Rápida $(R R)$, Média (RM) e Lenta (RL), - ainda que essa ruptura possa variar em função das condições climáticas - e está relacionada a superfície específica dos agregados, de forma que emulsão RR tem pouca função no uso com agregados e de ruptura média são utilizadas com agregados graúdos (Clerman, 2004).

Emulsões catiônicas de ruptura lenta são especialmente utilizadas em misturas com granulometria densa ou alto teor de finos. O tempo de ruptura mais lento permite trabalhabilidade por períodos mais longos, o que implica diretamente no tempo de cura e susceptibilidade a chuvas (James, 2006). O tempo de ruptura é determinante em cada aplicação, uma vez que a ruptura precoce pode afetar o desempenho da mistura. A emulsão deve permanecer estável durante o serviço a ser realizado.

A emulsão possui ainda vantagens no transporte e armazenamento, pois sua utilização não precisa ser imediata como a espuma. Seu fornecimento em obras se dá através de caminhões tanque.

A cura é o processo de perda de água, quando o betume residual da emulsão e aditivos alcançam suas propriedades. De acordo com Salomon (2008), os principais fatores que interferem nos processos de ruptura e cura das emulsões são: superfície específica, carga elétrica e características químicas do agregado, química dos aditivos (cimento e cal), temperatura, umidade relativa, características do agente emulsificante, viscosidade do asfalto, ou ainda fatores de aplicação como compactação e técnica executada. O processo pode levar meses para ser finalizado, conforme mencionado por Bernucci et al. (2007). 
Testes com emulsões são realizados com os seguintes objetivos: (i) verificar trabalhabilidade (teor de betume, viscosidade, peneiração), (ii) identificar condições de ruptura (desemulsabilidade, cimento teste, destilação) e (iii) testes com resíduo (penetração, ductilidade). As principais características das emulsões, entretanto, referem-se à capacidade desta em recobrir os agregados com um filme uniforme (ensaio de viscosidade) e também sua estabilidade durante a aplicação (ensaio de peneiramento) para evitar problemas de aglutinação de partículas e perda de homogeneidade (Kadrmas, 2006).

O Brasil tem um consumo considerado elevado de emulsão em relação ao consumo de asfalto, isto se deve especialmente à facilidade de envio para áreas não produtoras, já que as refinarias estão próximas da costa. De acordo com Deneuvillers (2007) apud Balbinot (2007), o Brasil figura como quarto maior produtor mundial de emulsão asfáltica, conforme Tabela 1.

\section{Tabela 1 - Produção de emulsão asfáltica}

\begin{tabular}{|c|c|}
\hline \multicolumn{2}{|c|}{$\begin{array}{l}\text { Produtores mundiais de emulsão asfáltica } \\
\text { (Denneuvillers, 2007 apud Balbinot, 2007) }\end{array}$} \\
\hline País & Emulsão (t) \\
\hline Estados Unidos & 2.400 .000 \\
\hline França & 977.000 \\
\hline México & 650.000 \\
\hline Brasil & 400.000 \\
\hline Espanha & 354.000 \\
\hline Canadá & 350.000 \\
\hline Reino Unido & 150.000 \\
\hline Itália & 135.000 \\
\hline Alemanha & 120.000 \\
\hline
\end{tabular}

\subsubsection{Aditivos}

As emulsões utilizadas em misturas recicladas podem ser combinadas com aditivos para diferentes finalidades. Entre os mais comuns encontram-se os agentes rejuvenescedores e os polímeros, segundo James (2006). Os agentes rejuvenescedores são utilizados em processos de reciclagem a quente; nos processos de reciclagem a frio são utilizados agentes rejuvenescedores 
emulsionados. Tendo em vista o rejuvenescimento do ligante envelhecido pode-se então considerar que o teor existente fará parte do teor total de ligante asfáltico da mistura reciclada, desencadeando assim uma redução no consumo de ligante adicional.

De acordo com Mallick et al (2010) as misturas recicladas a quente que contemplaram uso de agente rejuvenescedor, obtiveram melhores resultados em relação àquelas misturas sem o agente, tanto em misturas aplicadas em campo, quanto as produzidas em laboratório. A adição destes agentes representa aumento nos valores de resistência e módulo, aproximando estes resultados aos obtidos para misturas convencionais. Contudo, conforme mencionado anteriormente, no processo de reciclagem a frio, o agregado fresado é considerado um agregado "negro" sem características de rejuvenescimento exploráveis do ligante envelhecido.

Polímeros são cadeias de moléculas unidas por ligações covalentes. Os polímeros inseridos nas emulsões podem ser elastômeros ou plastômeros, e modificam a estrutura e viscoelasticidade do asfalto. A incorporação de polímeros elastômeros é atualmente normatizada pela ANP, Agência Nacional de Petróleo, através da Resolução RANP n 5 de 2009, e indicado com a letra E na classificação das emulsões. O polímero SBS, muito utilizado em asfaltos no Brasil, incrementa recuperação elástica e diminui a susceptibilidade térmica (ABEDA, 2001). O aumento de resistência à fadiga e incremento na adesividade também são características melhoradas pela incorporação de polímero SBS.

De acordo com Leite (1999), o polímero elastômero termoplástico SBS, sigla para estireno-butadieno-estireno, onde o estireno (termoplástico) é responsável por fornecer maior resistência ao polímero, e o butadieno (termoelástico) confere elasticidade. O SBS modifica o comportamento reológico do asfalto; a viscoelasticidade apresenta menor variação sob efeito da temperatura (Lucena et al., 2008). Por esta razão, o SBS é muito utilizado em regiões com elevado gradiente térmico, garantindo elasticidade ao asfalto em baixas temperaturas e rigidez em altas temperaturas. 
Os polímeros devem ser dispersos nas emulsões em proporções adequadas, uma vez que o aumento excessivo da quantidade não traz necessariamente benefícios, podendo ainda exigir maior energia de agitação. Além disso, o peso molecular do polímero deve ser compatível com o CAP, para garantir a correta dispersão (Leite, 1999).

As características dos polímeros atuam sobre o resíduo das emulsões. Quando se inicia o processo de ruptura, ocorre o fenômeno da coalescência, no qual os glóbulos de asfalto se unem formando uma película ou filme que recobre o agregado (Zegarra, 2007). O polímero SBS interage fisicamente, formando uma rede externa a esta película de asfalto (Machado, 2007); a função do polímero é de ampliar a flexibilidade do filme asfáltico, de forma que o teor de polímero incorporado na emulsão também é fonte de variabilidade no desempenho das misturas produzidas.

Segundo Willians et al. (1992) os polímeros adicionam características às misturas recicladas como alta coesão inicial (maior capacidade estrutural) e maior resistência a deterioração por fadiga. A rede formada pelo polímero aumenta a elasticidade da mistura asfáltica; a rede amortece os impactos aplicados na estrutura da mistura asfáltica, e ainda diminui a área exposta de ligante asfáltico, reduzindo assim a oxidação.

Observa-se um consenso de que o desempenho de pavimentos que utilizam asfalto modificado por polímero é superior àqueles que utilizam asfalto convencional, contudo alguns estudos de campo mostram que esse desempenho não é uniforme e depende de variáveis como tráfego, materiais, clima, dentre outros (Quintus et al., 2001) e precisam ser bem avaliados.

\subsubsection{Fíler Ativo - Estabilizante Químico}

A reciclagem a frio com uso de emulsão permite a incorporação de fíler ativo, a fim de melhorar algumas características das misturas. Misturas recicladas apresentam melhorias mensuráveis na resistência após a construção, devido à cura dos aditivos de reciclagem e/ou modificadores, e redução na porcentagem de vazios com 0 
tráfego. A taxa de aumento da resistência é maior durante os primeiros meses após a construção, mas continua aumentando por até dois anos (ARRA, 2001).

De acordo com Carter (2009), no Canadá, a maioria dos procedimentos de reciclagem utilizam cimento como aditivo, embora haja uma série de outros aditivos que podem ser utilizados na reciclagem. Segundo Sachet (2007), o cimento é o agente estabilizador mais utilizado em todo o mundo, tanto como um agente único, como em conjunto com outros agentes, geralmente com agentes estabilizadores betuminosos. A grande disponibilidade de cimento contribui pra sua extensa utilização.

O cimento atua aumentando a rigidez inicial das misturas recicladas a frio, garantindo capacidade de suporte quando a emulsão asfáltica não teve cura suficiente para garantir a capacidade de suporte requerida durante a abertura ao tráfego. Contudo o aumento excessivo de rigidez provocado por teores mais elevados de cimento podem reduzir características de fadiga, além dos riscos de trincamento por contração. O teor de cimento deve, portanto ser avaliado criteriosamente para assegurar desempenho adequado.

Os cristais de cimento que oferecem resistência à mistura também são susceptíveis à ruptura por efeito do carregamento do tráfego.

\subsubsection{Dosagem da Mistura Reciclada}

Os procedimentos de laboratório podem apresentar muita variação em função das especificações ou rotinas regionais. Mesmo com muita experiência acumulada na dosagem de misturas recicladas a frio, os norte-americanos não definiram um único método para a dosagem destas misturas. Conforme já mencionado no item 2.3, segundo o MnDOT (2000), os mais relevantes procedimentos de dosagem norteamericanos são AASHTO, USACE, Califórnia (CaDOT), Oregon (ODOT), Pennsylvania (PaDOT) além do Ministry of Tranportation of Ontário do Canadá. Estas agências possuem procedimentos próprios para a dosagem, e seus parâmetros essenciais serão descritos a seguir: 
A AASHTO (T312) recomenda obtenção de amostras extraídas com o mesmo equipamento fresador de obra, garantindo faixa granulométrica similar àquela que será produzida em campo. Misturas são preparadas para alcançar teor de umidade (água de molhagem + água da emulsão) total de 3\%, e com variações de 0,5\% de teores de emulsão. São moldados corpos-de-prova Marshall com 50 golpes por face e curados por seis horas à temperatura de $60^{\circ} \mathrm{C}$, e posteriormente à temperatura ambiente por doze horas. Outros quatro grupos de corpos-de-prova são preparados com teor ótimo de emulsão e variações de $0,5 \%$ nos teores de umidade total. As misturas têm volume de vazios entre $9 \%$ e $14 \%$.

O DOT da Califórnia obtém material da britagem do pavimento, e este material é avaliado em termos de graduação, teor de betume residual, e viscosidade do asfalto envelhecido recuperado. São preparadas amostras com $2 \%$ de umidade e diferentes teores de emulsão e compactadas no compactador do tipo kneading, com posterior cura em estufa por seis horas na temperatura de $60^{\circ} \mathrm{C}$. O teor ótimo é resultado do maior recobrimento, com referência ao volume de vazios de $4 \%$.

A agência de Ontário permite que as amostras sejam obtidas por desagregação de amostras extraídas da pista ou por equipamento fresador, e determina a graduação dos agregados, o teor de asfalto residual, penetração e viscosidade do asfalto recuperado. Amostras são preparadas com variação de $0,5 \%$ de ligante e teor de umidade (água de molhagem + água da emulsão) total de 4,5\%. Após uma hora da mistura, são compactados corpos-de-prova com 50 golpes por face no compactador Marshall e curadas por 16 a 24 horas a temperatura ambiente; após este período recebem complementares 25 golpes por face. $O$ volume de vazios varia entre 8 e $12 \%$.

O DOT do Oregon obtém as amostras de pista por fresagem e avalia o material através da graduação do agregado fresado, da graduação do agregado após extração de betume, e penetração e viscosidade do asfalto recuperado. Baseado em equação empírica desenvolvida por meio de dados de observações de campo, é estimado o teor ótimo de emulsão. As amostras são preparadas com o compactador do tipo kneading, com variações de $0,3 \%$ de ligante; são efetuadas curas por 12 
horas, aproximadamente, e re-compactadas em seguida. Permanecem em estufa por 24 horas a $60^{\circ} \mathrm{C}$ e após a extração do molde, por mais 72 horas a temperatura ambiente.

O DOT da Pennsylvania trabalha com o material obtido pela desagregação de amostras extraídas de pista e avaliadas em termos de graduação do agregado fresado, do agregado após extração de betume e da viscosidade e penetração do asfalto recuperado. Varia-se o teor de umidade entre 3\% e 7\% para teor de emulsão pré-fixado de $2,5 \%$, este procedimento visa estabelecer o teor de umidade que será utilizado na dosagem Marshall. Em seguida é variado o teor de emulsão entre 2,0\% e 3,5\%. São moldados corpos-de-prova Marshall, com 75 golpes por face e curadas em temperatura ambiente por 14 a 24 horas. Após a extração do molde, cura-se por 72 horas à temperatura de $40^{\circ} \mathrm{C}$ em estufa.

O estado americano de Nevada utiliza o método Hveem para dosagem de misturas asfálticas, incluindo misturas recicladas a frio. O método preconiza a avaliação in situ do pavimento deteriorado (módulo de resiliência primordialmente), definição do teor ótimo em função da densidade e avaliação da estabilidade em três estágios de cura e verifica a suscetibilidade aos danos por umidade - porcentagem máxima de perda de 70\% (Bemanian, Polish et al., 2006).

Apesar das variações constatadas, o que se observa é que o material deve ser o mais representativo do utilizado durante a construção e que as variações de teor de ligante e de umidade devem ser avaliadas em detalhe. Observa-se também que os procedimentos de cura procuram de alguma forma, representar as condições de campo em relação à remoção de água, porém com temperatura controlada. Neste caso, dada a variabilidade encontrada nas agências dos países com maior desenvolvimento tecnológico, pode-se adotar processos nacionais uma vez que as condições climáticas do Brasil são muito diferentes dos países do hemisfério norte.

O DNIT (DNER ME 117/94) indica o seguinte procedimento para a confecção de corpos-de-prova de mistura betuminosa a frio com emulsão: preparar a mistura e aguardar uma hora antes de compactar (para emulsões de ruptura lenta), utilizando compactador Marshall, aplicar 50 ou 75 golpes por face, levar a estufa por 24 horas 
à temperatura de 60 graus e, depois desta cura, extrair o corpo-de-prova do molde. Aguardar duas horas antes de iniciar procedimentos para qualquer ensaio.

As questões relativas à ruptura da emulsão mostraram não ter impacto significativo na pesquisa realizada por Cross (2003), que conclui que as amostras podem ser compactadas antes ou depois da ruptura sem causar efeito significativo no comportamento do corpo-de-prova. Esta constatação é baseada em uma experiência de laboratório, podendo não refletir a prática nas execuções de camadas recicladas com emulsões.

Segundo David (2006) o procedimento adotado pelo DNIT é muito similar ao adotado pela FHWA (1994) sendo esta uma importante constatação para a ratificação da norma brasileira.

\subsubsection{Propriedades Mecânicas de Misturas Recicladas em Laboratório}

De acordo com FHWA (1997), as características do material extraído da pista exercem enorme influência no desempenho do pavimento, especialmente no que concerne à granulometria do agregado fresado e ao teor de betume residual (relativo aos grumos de asfalto existentes). Sebaaly et al. (2004) ainda identificam como fator de influência, a fragilidade e a elevada rigidez da mistura deteriorada por oxidação e efeitos do tráfego, mostrando a importância de verificar as características do ligante envelhecido, de forma que a partir das características do novo ligante adicionado, se obtenha uma mistura com a flexibilidade desejável.

As propriedades físicas e o comportamento mecânico de misturas recicladas são indicativos de previsão de desempenho, que permitem avaliar e nortear a aplicabilidade das misturas de tal forma que possam ser reproduzidas em campo com relativa previsibilidade, conhecidos os ciclos de envelhecimento. A mistura também deve ter estabilidade inicial para abertura ao tráfego, permitir compactação adequada para obtenção do volume de vazios projetado. 
Para atender esta necessidade, os ensaios mais utilizados são resistência à tração por compressão diametral, módulo de resiliência, dano por umidade induzida, deformação permanente e Cântabro, sendo os dois primeiros mais utilizados no Brasil. A ARRA (2001) indica a avaliação da perda por umidade induzida, como resultado crucial na adoção de misturas asfálticas recicladas a frio.

Os ensaios de deformação permanente são incipientes de estudos, embora já possuam regulamentação em alguns países como Canadá, que limita a deformação permanente em laboratório em 10 \% para este tipo de mistura. Estudos realizados por Carter (2009) mostraram que misturas com menos teor de ligante apresentaram melhor comportamento, contudo deve-se avaliar a possibilidade de o simulador a 60 @C não aumentar a oxidação, como faz em misturas tradicionais, e sim apenas acelerar a cura do material.

O ensaio espanhol Cântabro (NLT-352, 2000) recebe distinção entre misturas a quente e misturas a frio, sem diferenciar, no entanto misturas convencionais de misturas recicladas. O número de rotações do tambor Los Angeles utilizado no ensaio é menor para misturas a frio, em virtude de sua maior fragilidade, ou menor adesividade e coesão.

\subsubsection{Equipamentos de Execução em Campo}

Os equipamentos necessários aos processos de reciclagem são fundamentais para o sucesso das técnicas. Por serem equipamentos específicos e diferenciados, estes geralmente interferem nos custos das intervenções. A comparação com técnicas convencionais, entretanto, não deve se restringir aos equipamentos, mas aos demais benefícios envolvidos no processo (Fresar, 2010).

As altas taxas de produtividade da reciclagem exigem preparação estruturada dos trabalhos que serão desenvolvidos em pista. Os equipamentos que compõem o processo devem ser especificados e as etapas de trabalho desenvolvidas com base no projeto de restauração. O projeto ainda deve dirigir os tipos e quantidades de equipamentos envolvidos (ARRA, 2001). Entre os itens a serem observados estão: 
características do tráfego, condições da área lindeira e de acesso, geometria da via, meta de volume de produção, além das necessidades específicas de cada projeto.

Os equipamentos devem atender a questões relativas à espessura de fresagem, largura de pista, capacidade de produção e precisão de dosagem. A disponibilidade de novos equipamentos amplia a possibilidade de reciclar e permite adaptações para condições diferentes. Equipamentos modernos para reciclagem de misturas a quente podem ser facilmente adaptados para trabalhar com misturas convencionais (ARRA, 2009), ampliando condições de uso sem elevar os custos em demasia.

Os processos de reciclagem a frio in situ são regularmente compostos por unidade recicladora, que realiza fresagem, seleção granulométrica e misturação (operações que podem eventualmente ser separadas em equipamentos distintos); tanque de ligante asfáltico e tanque de água que devem ser acoplados à unidade recicladora; motoniveladora; equipamentos de compactação: rolo pneumático, rolo metálico liso e rolo tandem vibratório, de acordo com a espessura da camada e o nivelamento do material (Figura 4). Segundo DNER (DNER-ES-405/2000) o unidade recicladora deve ter dispositivo de regulagem da espessura da camada do pavimento que deve ser removida.

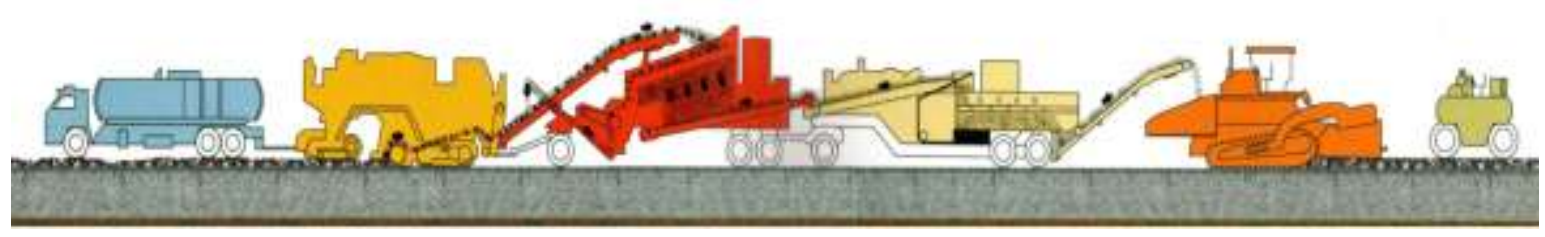

Figura 4 - Sequência de equipamentos para a reciclagem a frio in situ com trem de reciclagem (Fonte: Brown\&Brown, 2009)

\subsubsection{Controle Tecnológico de Campo}

As aplicações de misturas em pista devem estar sempre associadas a parâmetros de controle que possam garantir o desempenho projetado. Misturas nãoconvencionais, com sistemas de aplicação muito distintos costumam carecer de regulamentação para controle tecnológico, revelando poucos estudos para 
desenvolvimento técnico, o que impede a adoção de medidas de controle por órgãos públicos.

O controle tecnológico se fundamenta na obtenção de parâmetros essenciais de desempenho e na freqüência com que esses dados devem ser obtidos. O Brasil possui regulamentações específicas para pavimentos reciclados, contudo, a reciclagem a frio in situ com emulsão não possui regulamentação nacional, apenas o órgão estadual DER implementou norma sob a identificação (DER-ET-DE-P00/34, 2006) - Reciclagem de pavimento asfáltico in situ com emulsão.

Os parâmetros de controle elencados nesta norma são: granulometria, durabilidade e desgaste de agregados pelo ensaio Los Angeles, faixa granulométrica aplicada aos volumes de tráfego, determinação dos valores de CBR, características dos materiais e da mistura, massa especifica a cada 300 metros, espessura de camada a cada 300 metros, medidas de largura a cada 20 metros, e medidas de deflexão a cada 20 metros em faixas alternadas.

DNIT (DNER ES 405/2000) possui regulamentação de controle para reciclagem a frio "in situ" com espuma de asfalto, cujos parâmetros são: desgaste, forma e durabilidade de agregados virgens, espessura, granulometria e teor de betume de camadas existentes (poço de sondagem a cada 500 metros), medidas de volume de cimento incorporado a cada 250 metros, massa específica, granulometria e teor de betume do material reciclado, moldagem de corpos-de-prova para medidas de resistência à tração e massa específica (laboratório), e medidas de deflexão em campo a cada 100 metros.

De acordo com Sachet (2007), deve ser somada a estes parâmetros a realização do ensaio Cone de Penetração Dinâmica (DCP - Dynamic Cone Penetrometer), como estimativa de capacidade de suporte das camadas e do ensaio de equivalente de areia, para medidas de densidade. Além disso, a frequência de medições deve ser ampliada, de modo a oferecer controle mais representativo das estruturas.

O controle tecnológico exerce papel fundamental no desenvolvimento tecnológico, pois garante execução eficiente, e permite avaliar sucessos e insucessos a partir de 
dados fundamentados em medidas de campo. Apenas alguns itens de controle foram contemplados na execução do trecho experimental avaliado nesta pesquisa, e são discutidos no capítulo 5 .

\subsection{Algumas Experiências Nacionais e Internacionais}

Muitas experiências têm sido relatadas sobre a execução e monitoramento de pavimentos reciclados a frio com uso de emulsão. No Brasil, assim como em diversos outros países, a reciclagem tem sido executada com utilização de deferentes produtos, como espuma de asfalto, cimento Portland e emulsão asfáltica. Algumas pesquisas procuram comparar o desempenho de misturas com materiais variáveis. Nos EUA, muitos departamentos de transporte estimulam a realização de processos de reciclagem e pesquisas para fins comparativos.

Thomas et al. (2000) avaliou in situ e em laboratório, pavimentos reciclados com emulsão asfáltica e adição de cal, com tratamento superficial como camada de rolamento. Os ensaios em laboratório de deformação permanente indicaram que as misturas recicladas têm baixa susceptibilidade à deformação permanente. $O$ desempenho em campo comprova esta característica. Observou-se também que as características da camada remanescente não tratada, sob a camada reciclada, podem contribuir para a aceleração do trincamento.

Sebaaly et al. (2004), avaliou o desempenho de duas rodovias de Nevada/ EUA, que foram submetidas ao processo de reciclagem a frio in situ, citando bons resultados de resistência em relação a trincamento e deformação permanente. Os parâmetros considerados integram o necessário para obtenção do índice de serventia (porcentagem de área trincada, porcentagem de área com buracos, afundamento em trilha de roda e índice de irregularidade longitudinal); os resultados mostraram que após três anos da reciclagem, as rodovias avaliadas mantinham nível de serventia superior a 4 .

A incorporação de polímero em emulsões tem sido avaliada desde a década de 1980 no Novo México/ EUA. Os trechos que receberam camada de rolamento de concreto asfáltico delgado apresentaram bom desempenho, tendo dobrado os 
valores de resistência à tração após um ano em relação ao período de construção. Após cinco anos da construção, iniciou o aparecimento de trincamento e deformação permanente mínima. Os benefícios proporcionados pelo uso de emulsão modificada por polímero não excluem a necessidade de uso de camada selante sobre a mistura reciclada, no entanto a pesquisa observou que em trechos sem camada selante não houve deterioração mais acelerada do que em trechos que tiveram camada selante.

No Brasil, Suzuki (2005) relata uma experiência de sucesso de reciclagem a frio sem uso de camada selante. A pista revelou bom aspecto das condições funcionais e foi avaliada estruturalmente a partir de medidas de deflexão, antes e depois da intervenção. Comparando a efetividade de beneficio da mistura reciclada em relação à camada deteriorada de concreto asfáltico, os resultados de módulo de resiliência de cada camada demonstraram um incremento de 45\%. Observou-se uniformidade na camada reciclada e aumento do raio de curvatura de deflexão, indicando o processo para restauração de pavimentos sem problemas estruturais críticos, e também a aplicação de camada selante, devido ao elevado volume de vazios.

A avaliação laboratorial de misturas asfálticas recicladas a frio com emulsão convencional realizada por David (2006) indicou que a adição de pó-de-pedra como fração fina para adequação de faixa granulométrica aumenta consideravelmente os valores de resistência à tração, módulo de resiliência e resistência a tração retida. $O$ aumento do teor de água não relevou melhoria nas características Marshall, além disso, o aumento do teor de ligante não reduziu significativamente o volume de vazios.

Em misturas recicladas com diferentes teores de agregados fresados incorporados, Moreira (2005) não identificou diferenças consideráveis no teor ótimo destas misturas, indicando que o ligante envelhecido aderido ao agregado fresado, não demonstrou características regenerativas que contribuíssem como parte de ligante atuante. Outro fator demonstrado por Moreira foram diferenças nos resultados dos ensaios de misturas compactadas por impacto, ou por amassamento; a compactação por amassamento conduz a valores maiores e a compactação por impacto gera maiores dispersões nos resultados. 


\section{ENSAIOS DE LABORATÓRIO}

\subsection{Caracterização dos materiais}

\subsubsection{Agregados Fresados}

Os agregados utilizados nesta pesquisa são provenientes do trecho experimental executado na Rodovia Régis Bittencourt. Este material foi extraído durante o processo de execução da reciclagem pela unidade fresadora de modo a ter uma amostra com a mesma faixa granulométrica que foi aplicada no pavimento reciclado. Não houve adição de agregados virgens, sendo a mistura composta de $100 \%$ de agregados fresados.

Durante o processo de fresagem, os aditivos, cal ou cimento, são incorporados por espalhamento na pista previamente à fresagem; este procedimento implica em presença de fíler ativo nos agregados (Figura 5). Também durante o processo de fresagem, água é incorporada nos teores de projeto, contribuindo no resfriamento do cilindro fresador e reduzindo a produção de pó.

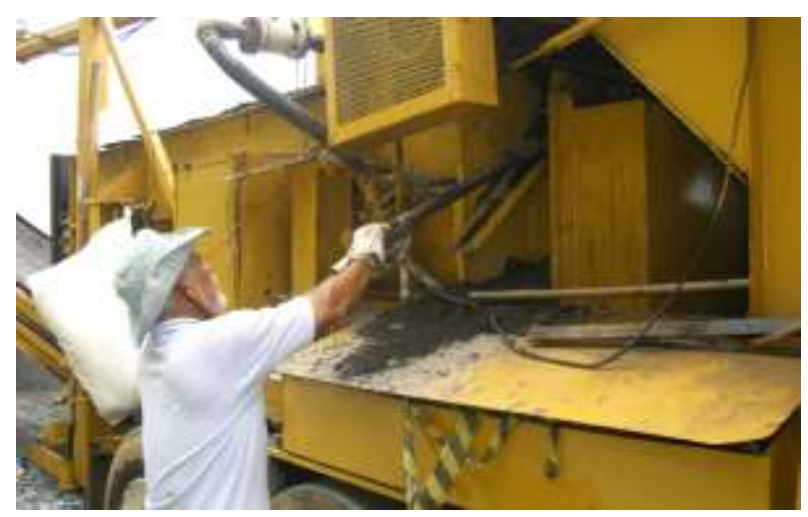

Figura 5 - Retirada de agregado fresado, antes da misturação com emulsão

O material foi acondicionado em sacos e em laboratório foi misturado e distribuído de modo a permitir a secagem em temperatura ambiente do teor de água incorporado (Figura 6). O controle foi feito pela constância de peso. Mallick (2007) sugere que altas temperaturas sejam maléficas para o agregado fresado, portanto a 
não exposição desse material a processos com temperaturas elevadas, evita sua deterioração adicional.

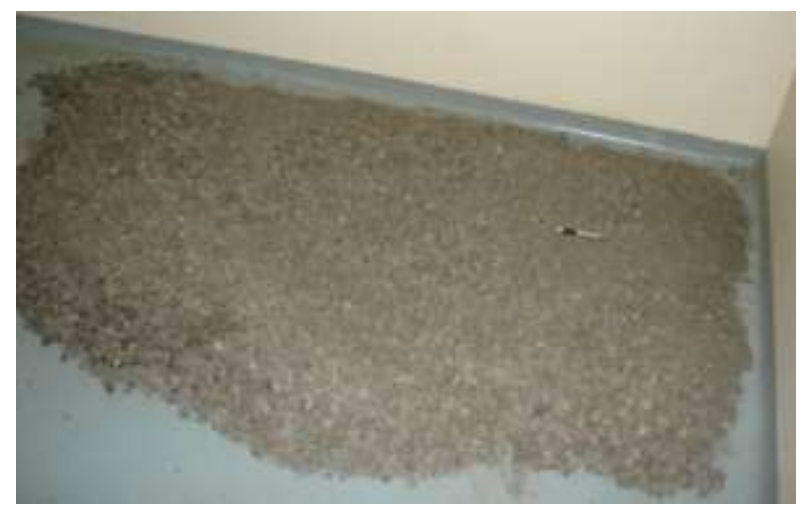

Figura 6 - Espalhamento dos agregados fresados em laboratório

Após a secagem, diversas amostras do material foram submetidas a medidas de alcalinidade, com auxílio de um peagâmetro, a fim de se verificar se haviam diferenças consideráveis que indicassem a presença de cal ou cimento. Para estas medidas foram utilizados dois tipos de amostragem: materiais graúdos retidos na peneira $12,5 \mathrm{~mm}$ e materiais finos passantes na peneira $\mathrm{N}^{\circ} 200$, sempre em solução com água destilada (Figura 7). Não existe normatização para este procedimento específico com agregados fresados.
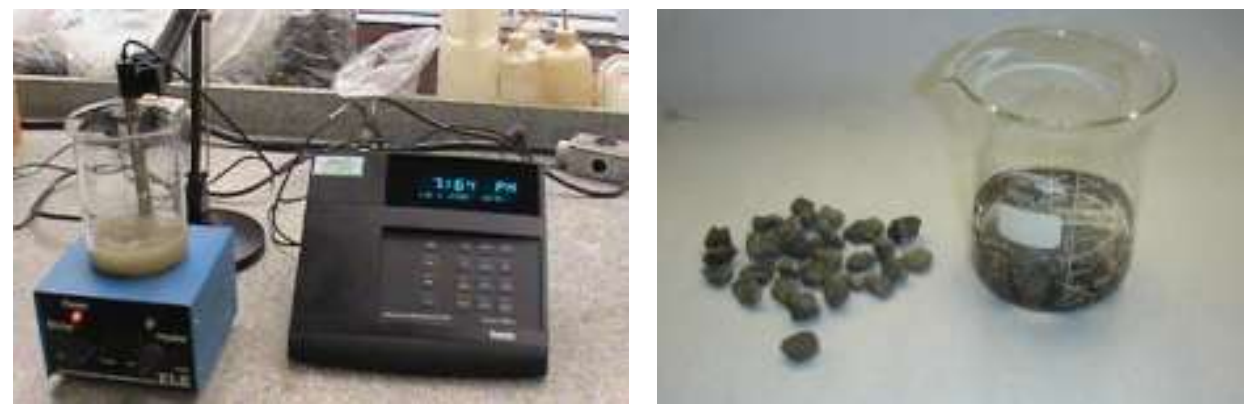

Figura 7 - Peagâmetro na determinação do pH com agregados graúdos e finos

A presença de cal indicaria $\mathrm{pH}$ maior que 7 e a presença de cimento indicaria $\mathrm{pH}$ maior que 12,5. Os resultados apresentados na Tabela 2, com as duas amostras indicaram resultados médios de $\mathrm{pH}$ entre 7 e 8 , sendo portanto, um indicativo de que o fíler pode ser considerado inerte. 
Tabela 2 - Valores obtidos nas medidas de ph

\begin{tabular}{|c|c|c|c|}
\hline $\begin{array}{c}\text { Tipo de } \\
\text { agregado }\end{array}$ & $\begin{array}{c}\text { Amostra } \\
\text { número }\end{array}$ & $\begin{array}{c}\text { Medidas de } \\
\mathrm{pH}\end{array}$ & \multirow{2}{*}{ Média } \\
\hline \multirow{3}{*}{ Finos } & 1 & 7,015 & \multirow{3}{*}{7,307} \\
\cline { 2 - 3 } & 2 & 7,742 & \\
\cline { 2 - 3 } & 3 & 7,164 & \\
\hline \multirow{3}{*}{ Graúdos } & 4 & 7,944 & \multirow{2}{*}{7,831} \\
\cline { 2 - 3 } & 5 & 7,632 & \\
\cline { 2 - 3 } & 6 & 7,916 & \\
\hline
\end{tabular}

\subsubsection{Abrasão Los Angeles}

O ensaio realizado com auxílio do Tambor de Abrasão Los Angeles estima o desgaste do agregado durante as etapas de usinagem, construção e vida de serviço (Figura 8).
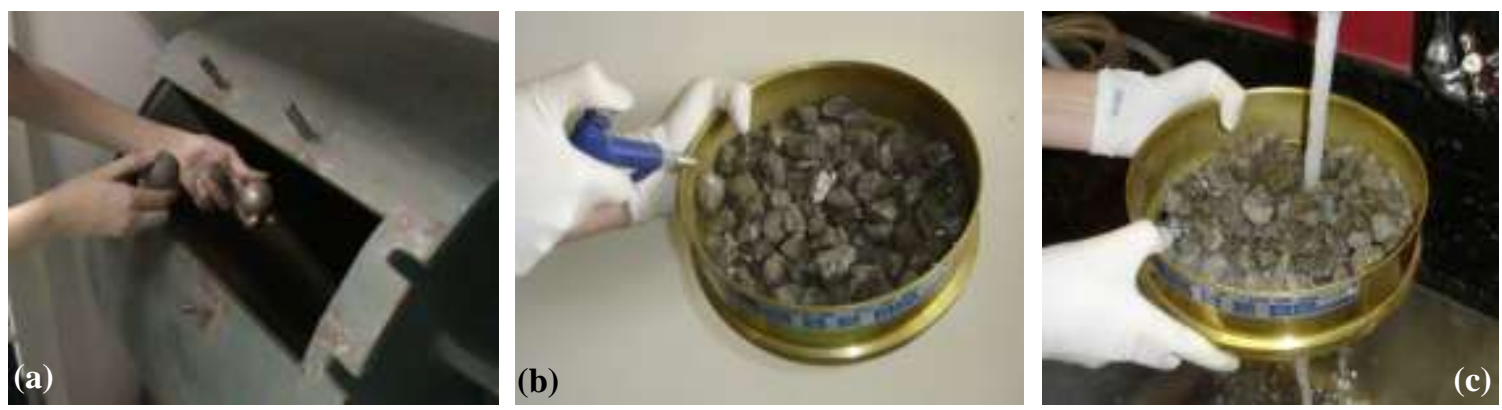

Figura 8 -Ensaio de abrasão Los Angeles (a) para agregados fresados, livres de pó (b) e lavados (c)

A norma utilizada (DNER-ME-035/98, 1998) não define procedimentos específicos para agregado fresado, assim optou-se por ensaiar de duas formas diferentes: (i) sem lavagem, apenas com o uso de ar comprimido sobre o material distribuído na peneira e, (ii) com lavagem, em acordo com a norma. A temperatura de $105^{\circ} \mathrm{C}$ a $110^{\circ} \mathrm{C}$ a que a norma se refere é muito alta para este material, composto também de grumos de asfalto que podem interagir a altas temperaturas, alterando as características do material. Por esta razão o material ficou em estufa a $30^{\circ} \mathrm{C}$ por sete dias (até a constância de peso). Não foram realizados ensaios em amostras com destorroamento dos grumos asfálticos. 
Foi escolhida a graduação B (2500 gramas \#12,5 mm + 2500 gramas \# 9,5 mm) e o ensaio foi realizado com utilização de 11 esferas, num total de 500 rotações, após as quais, os materiais retidos na peneira de $1,7 \mathrm{~mm}$ foram pesados. A norma utilizada no ensaio não estabelece valores limites, de modo que se procurou comparar com as especificações para agregados virgens, constante na norma da ABNT (ABNT NBR 6465); quatro amostras ensaiadas indicaram valor médio de perda de $23 \%$, valor considerado adequado tendo em vista o limite de $40 \%$ estabelecido na norma citada (Tabela 3).

\begin{tabular}{|c|c|c|c|c|}
\hline & Amostra 1 & Amostra 2 & Amostra 3 & Amostra 4 \\
\hline Peso Inicial (g) & 5002,1 & 4959,9 & 4996,8 & 4988,6 \\
\hline Peso final $(\mathrm{g})$ & 3916,7 & 3825,2 & 3861,8 & 3801,1 \\
\hline$\%$ perda & 21,7 & 22,9 & 22,7 & 23,8 \\
\hline
\end{tabular}

O ensaio neste material é influenciado pelo teor de ligante incorporado (grumos de asfalto envelhecido) que em parte protege o material pétreo do desgaste, contudo, estes grumos podem desprender durante o ensaio.

\subsubsection{2 Índice de Forma}

A determinação do índice de forma objetiva caracterizar a presença de agregados lamelares, uma vez que o desempenho das misturas asfálticas varia de acordo com a forma dos agregados graúdos. Nesta determinação foi utilizada a norma (ASTMD4791), com graduação distribuída entre as peneiras de abertura 9,5 mm, 12,5 mm e $19 \mathrm{~mm}$. O procedimento manual determina por meio de equipamento específico, a relação de largura e comprimento de cada agregado amostrado (Figura 9), no caso foi utilizada a relação de grãos com proporção maior do que 1:3. Como resultado deste ensaio obteve-se o predomínio de partículas cúbicas, mais indicadas para uso em mistura asfáltica, tendo em média $12 \%$ de partículas lamelares, valor em acordo com a mesma norma que estabelece valor máximo de $20 \%$. 

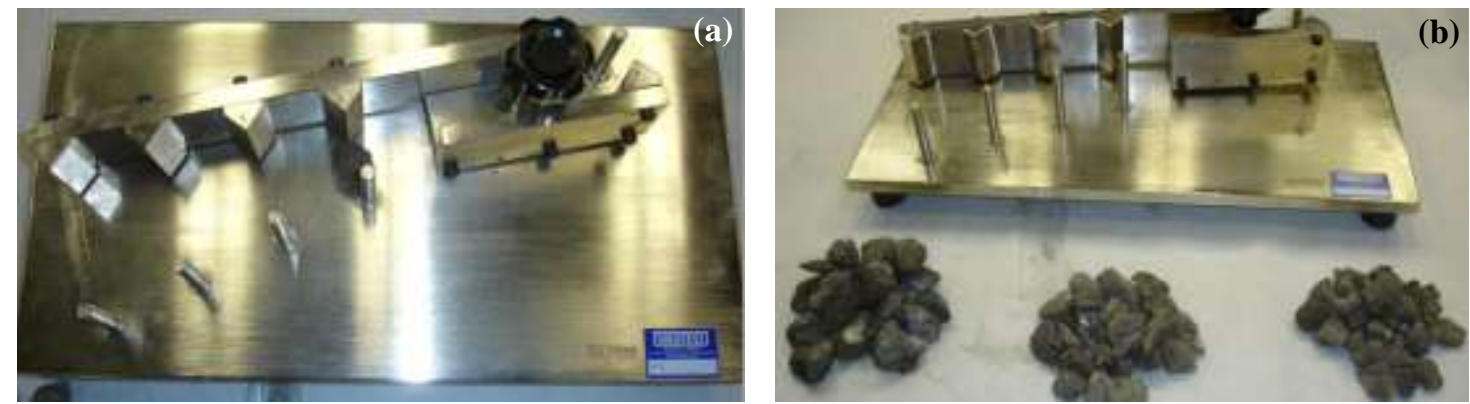

Figura 9 - Equipamento para determinação da forma dos agregados (a) e porções de material, separados segundo o índice de forma (b)

O índice de forma para agregados fresados esta diretamente associado à forma de obtenção, sendo que a fresagem a frio, embora forneça graduação diferente da utilizada na composição da camada envelhecida, garante relativa forma cúbica aos agregados, através do processo de fratura da camada do pavimento.

\subsubsection{Granulometria}

O material foi quarteado e então procedida a verificação granulométrica por peneiramento conforme preconizado na norma DNER-ME 083/98. As frações obtidas encontram-se na Figura 10 e na Tabela 4.

Tabela 4 - Análise Granulométrica de amostras de agregado fresado no trecho experimental

\begin{tabular}{|c|c|c|c|c|c|c|c|}
\hline $\begin{array}{c}\text { Peneira de malha } \\
\text { quadrada }\end{array}$ & \multicolumn{7}{|c|}{ Porcentagem passante, em massa } \\
\hline $\mathrm{mm}$ & $\mathrm{n}^{0}$ ou " & Amostra 1 & Amostra 2 & Amostra 3 & Amostra 4 & Limite inferior & Limite superior \\
\hline 25 & $1 "$ & 100,0 & 98,3 & 99,4 & 100,0 & 85,0 & 100,0 \\
\hline 19,1 & $3 / 4 "$ & 95,0 & 95,3 & 94,5 & 91,8 & 75,0 & 92,0 \\
\hline 12,5 & $1 / 2^{\prime \prime}$ & 79,2 & 72,7 & 72,0 & 59,3 & 60,0 & 75,0 \\
\hline 4,76 & 4 & 36,3 & 21,7 & 30,4 & 23,5 & 30,0 & 45,0 \\
\hline 0,59 & 30 & 6,7 & 4,5 & 4,3 & 4,9 & 1,0 & 7,0 \\
\hline 0,075 & 200 & 0,3 & 0,0 & 0,5 & 0,4 & 1,0 & 3,0 \\
\hline
\end{tabular}




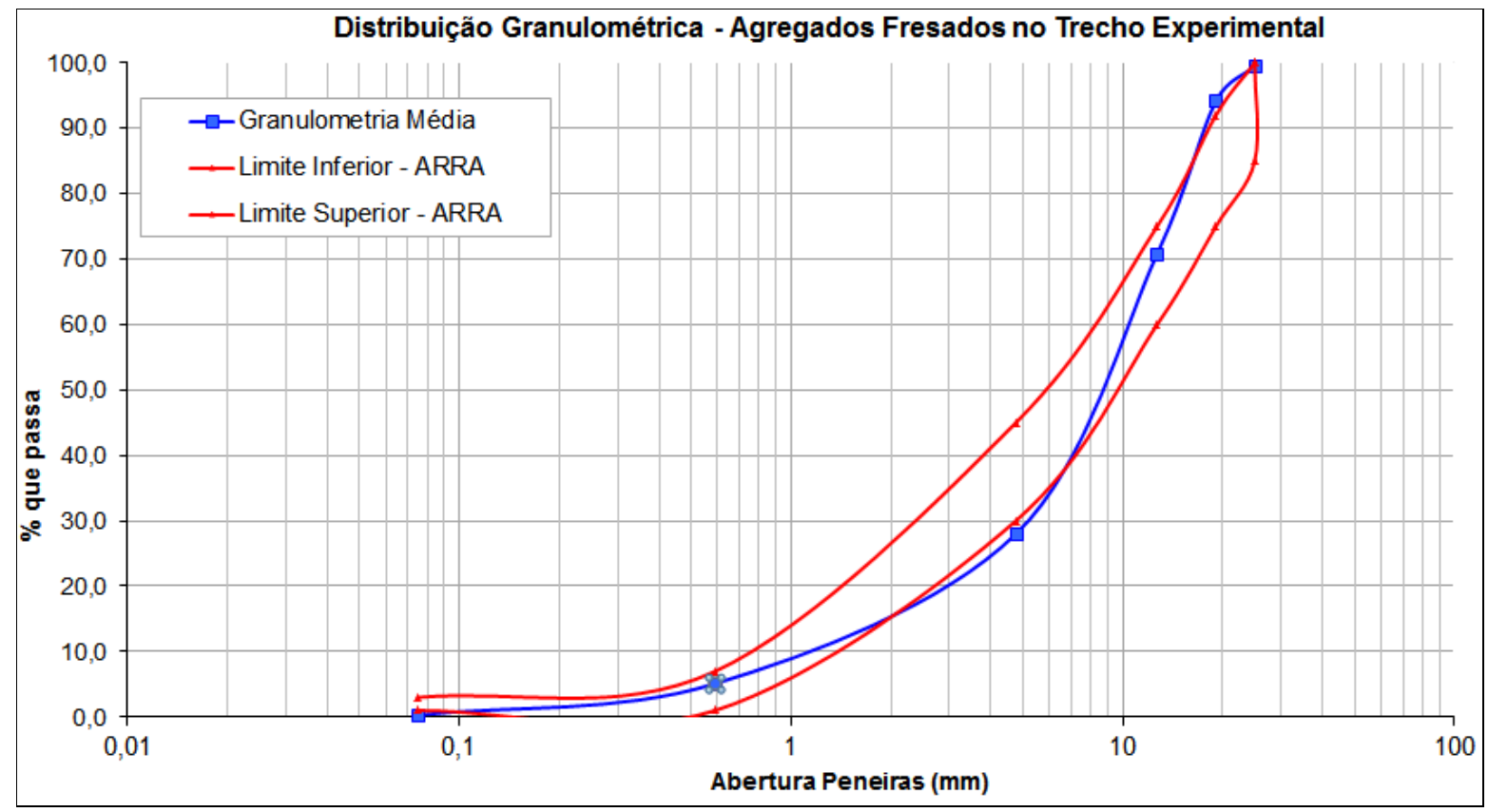

Figura 10 - Distribuição granulométrica média dos agregados fresados obtida por peneiramento de quatro amostras

A faixa granulométrica mostra que o agregado fresado possui poucos finos, ainda que o material amostrado contenha fíler incorporado em pista (considerado inerte). A porcentagem reduzida de finos aumenta o volume de vazios da mistura reciclada. É importante lembrar que a faixa granulométrica é função da velocidade de avanço da unidade fresadora, e que para obter maior proporção de finos, a velocidade deve ser mais baixa (Bonfim, 1999). A amostragem revela também que a velocidade de avanço permanece relativamente constante, com pequenas variações na distribuição granulométrica. Outro fator que pode afetar a distribuição granulométrica é a homogeneidade ou heterogeneidade dos materiais asfálticos que compõem a camada fresada; quanto mais intervenções existentes no revestimento, mais heterogêneo deve ser o material.

\subsubsection{Emulsão}

A emulsão utilizada nesta pesquisa é classificada pelas especificações nacionais como Emulsão Catiônica de Ruptura Lenta modificada por Polímero Elastomérico SBS, RL-1C E, conforme resultados apresentados na Tabela 5, constante no Regulamento técnico $n^{0}$ 5/2009 (ANP, 2009). 
Tabela 5 - Caracterização de emulsões com polímero. Fonte: ANP, 2009

\begin{tabular}{|c|c|c|c|c|}
\hline \multirow{3}{*}{ CARACTERÍSTICA } & \multirow{3}{*}{ UNIDADE } & \multirow{3}{*}{\begin{tabular}{|c|}
$\begin{array}{c}\text { Ruptura } \\
\text { Lenta }\end{array}$ \\
RL1C-E \\
\end{tabular}} & \multicolumn{2}{|c|}{ MÉTODO } \\
\hline & & & \multirow{2}{*}{$\begin{array}{l}\text { ABNT } \\
\text { NBR }\end{array}$} & \multirow{2}{*}{ ASTM } \\
\hline & & & & \\
\hline \multicolumn{5}{|c|}{ Ensaios para a emulsão } \\
\hline $\begin{array}{l}\text { Viscosidade Saybolt- } \\
\quad \text { Furol, a } 50^{\circ} \mathrm{C}\end{array}$ & $\mathrm{s}$ & 70 máx. & 14491 & D244 \\
\hline Sedimentação, máx. & $\%$ massa & 5 & 6570 & D6930 \\
\hline $\begin{array}{l}\text { Peneiração } 0,84 \text { mm, } \\
\text { máx. }\end{array}$ & $\%$ massa & 0,1 & 14393 & D6933 \\
\hline \multicolumn{3}{|c|}{ Resistência á água, mín. de cobertura (2) } & \multirow{3}{*}{6300} & \multirow{3}{*}{ D244 } \\
\hline Agregado seco & \multirow[b]{2}{*}{$\%$} & 80 & & \\
\hline Agregado úmido & & 60 & & \\
\hline Carga de partícula & - & & 6567 & D244 \\
\hline pH, máx. & - & 6,5 & 6299 & D244 \\
\hline $\begin{array}{l}\text { Destilação - solvente } \\
\text { destilado a } 360^{\circ} \mathrm{C}\end{array}$ & $\%$ volume & 0 & 6568 & D244 \\
\hline Resíduo seco, mín. & $\%$ massa & 60 & 14376 & D6934 \\
\hline $\begin{array}{l}\text { Desemulsibilidade } \\
\text { mín. }\end{array}$ & \multirow[t]{2}{*}{$\%$ massa } & - & \multirow[t]{2}{*}{6569} & \multirow[t]{2}{*}{ D6936 } \\
\hline máx. & & - & & \\
\hline \multicolumn{5}{|c|}{$\begin{array}{l}\text { Ensaios para o resíduo da emulsão obtido pela ABNT NBR } \\
\qquad 14896\end{array}$} \\
\hline $\begin{array}{l}\text { Penetração a } 25^{\circ} \mathrm{C} \\
100 \mathrm{~g}, 5 \mathrm{~s}\end{array}$ & $0,1 \mathrm{~mm}$ & $45-150$ & 6576 & D5 \\
\hline $\begin{array}{c}\text { Ponto de } \\
\text { amolecimento, mín. }\end{array}$ & ${ }^{\circ} \mathrm{C}$ & 55 & 6560 & D36 \\
\hline $\begin{array}{l}\text { Viscosidade } \\
\text { Brookfield a 135ํㅡ, } \\
\text { SP21, 20RPM, mín. }\end{array}$ & $c P$ & 600 & 15184 & D4402 \\
\hline $\begin{array}{l}\text { Recuperação elástica } \\
\text { a } 25^{\circ} \mathrm{C}, 20 \mathrm{~cm} \text {, mín. }\end{array}$ & $\%$ & 70 & 15086 & D6084 \\
\hline
\end{tabular}

Os ensaios realizados como controle sobre as emulsões são:

- Sedimentação - define a capacidade de estocagem das emulsões sem separação de fases;

- Peneiramento - caracteriza as dimensões dos glóbulos das emulsões, limitando glóbulos em grandes dimensões;

- Carga da partícula - define a carga da emulsão entre catiônica, aniônica e não iônica; 
- Destilação - determina as proporções de água e asfalto nas emulsões;

- Resíduo seco - caracteriza o teor de resíduo asfáltico nas emulsões por evaporação da água.

Os ensaios realizados sobre o resíduo das emulsões caracterizam o asfalto residual da mesma forma (penetração, ponto de amolecimento, viscosidade Brookfield e recuperação elástica). A emulsão asfáltica utilizada nesta pesquisa foi fornecida pela empresa Betunelkoch, como sua caracterização atendendo às normatizações supracitadas na Tabela 6.

Tabela 6 - Características da emulsão utilizada nesta pesquisa

\begin{tabular}{|l|c|c|}
\hline \multirow{2}{*}{\multicolumn{1}{|c|}{ Característica }} & Ruptura Lenta & Método \\
\cline { 2 - 3 } & RL 1C - E & ABNT NBR \\
\hline Viscosidade Saybolt-Furol, a $50^{\circ} \mathrm{C}(\mathrm{s})$ & 18 & NBR 14491 \\
\hline Resíduo Seco, min (\% massa) & 62,2 & NBR 14376 \\
\hline Peneiração 0,84 mm, máx (\% massa) & 0,01 & NBR 14393 \\
\hline Sedimentação, máx (\% massa) & 3 & NBR 6570 \\
\hline Carga de Partícula & Positiva & NBR 6567 \\
\hline
\end{tabular}

Como parte da avaliação do comportamento de misturas asfálticas recicladas, esta pesquisa comparou emulsões modificadas por polímero RL $1 \mathrm{C}$ - E, com emulsões convencionais $\mathrm{RL} 1 \mathrm{C}$. O objetivo desta comparação foi de verificar em laboratório a efetividade dos benefícios associados às emulsões modificadas por polímero.

A comparação entre essas misturas foi realizada pelo processo de dosagem Marshall, além de execução dos ensaios de comportamento mecânico, Cântabro, Resistência à Tração e Dano por Umidade Induzida. Os resultados encontram-se resumidos na Tabela 7. O processo de dosagem Marshall, bem como os ensaios de comportamento mecânico são descritos em mais detalhes no item 3.4.

Tabela 7 - Resumo de resultados dos ensaios de laboratório

\begin{tabular}{|c|c|c|c|c|c|}
\hline Tipo de Emulsão & $\begin{array}{c}\text { Peso } \\
\text { Específico } \\
\text { Aparente }\end{array}$ & $\begin{array}{c}\text { Volume de } \\
\text { Vazios }\end{array}$ & Cântabro & $\begin{array}{c}\text { Resistência } \\
\text { à Tração }\end{array}$ & $\begin{array}{c}\text { Resistência ao dano } \\
\text { por umidade } \\
\text { induzida }\end{array}$ \\
\cline { 2 - 6 } & $\mathrm{kN} / \mathrm{m} 3$ & $\%$ & $\%$ & $\mathrm{MPa}$ & $\%$ \\
\hline Emulsão Polímero & 19,5 & 22,0 & 17,8 & 0,355 & 71,8 \\
\hline $\begin{array}{c}\text { Emulsão } \\
\text { Convencional }\end{array}$ & 19,3 & 22,7 & 20,2 & 0,337 & 64,0 \\
\hline
\end{tabular}


Observa-se por estes resultados que as misturas recicladas com emulsão modificada por polímero apresentam comportamento superior às misturas recicladas com emulsão convencional. Os resultados atribuídos à modificação por polímero se justificam em relação aos ensaios de comportamento frente ao desgaste e à ação deletéria da água. A redução no volume de vazios e a maior densificação pode ser atribuído à facilidade de misturação e compactação propiciada pela emulsão modificada. A resistência à tração retida, ou menor perda por umidade induzida, apresentam resultados superiores nas misturas com emulsão modificada. $O$ desgaste verificado no ensaio Cântabro mostra melhor coesão entre as partículas na mistura com emulsão modificada por polímero.

\subsection{Dosagem da Mistura Reciclada}

O processo de dosagem de misturas recicladas não apresenta ainda consenso entre agências e departamentos de transporte pelo mundo. O Brasil, da mesma maneira que outros países, não apresenta procedimento específico de dosagem para misturas recicladas; contudo tem-se regularmente utilizado no país a metodologia de dosagem Marshall de misturas asfálticas a frio com emulsão, conforme procedimento do DNER-ME-107/94 (1994).

Foram moldados cinco corpos-de-prova para cada teor de emulsão asfáltica, nos padrões de medida de 101,6 mm de diâmetro por 63,5 mm de altura. Os agregados fresados foram separados em frações após secagem em temperatura ambiente. Cada corpo-de-prova foi composto e pesado individualmente, na seguinte seqüência: pesagem dos agregados, adição de fíler ativo, adição de água de molhagem, adição de emulsão, com homogeneização entre cada adição. As misturas preparadas em temperatura ambiente foram compactadas por meio de compactador Marshall, com 75 golpes por face.

O período de espera após a misturação e antes da compactação foi de uma hora para ruptura de emulsão catiônica de ruptura lenta. Conforme já mencionado, Cross (2003) não observou resultados expressivos no comportamento de misturas compactadas antes ou depois do início do ciclo de ruptura das emulsões. 
Os corpos-de-prova permaneceram por 24 horas em estufa a temperatura de $60^{\circ} \mathrm{C}$, tendo sido extraídos após duas horas em temperatura ambiente. Todos os corposde-prova foram pesados e medidas suas dimensões (Figura 11).
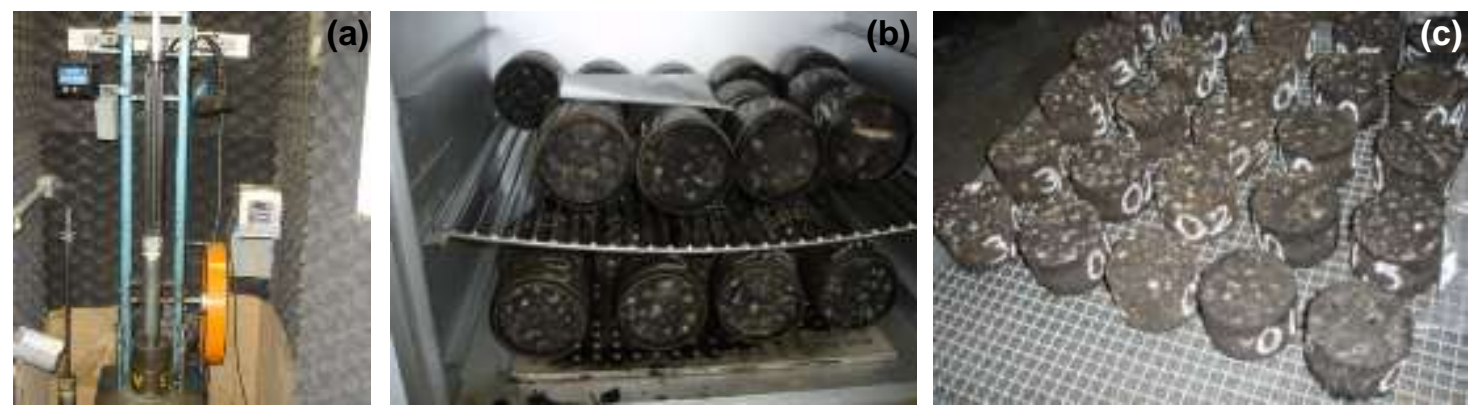

Figura 11 - Compactação (a) e cura dos corpos-de-prova (b) e (c)

As etapas que integraram o processo de dosagem, bem como os procedimentos e resultados de ensaio estão descritos nos itens a seguir.

\subsubsection{Composição Granulométrica}

A composição granulométrica das misturas asfálticas recicladas a frio in situ é determinada pelo método de extração dos materiais fresados, sendo somente controlado o diâmetro nominal máximo. As demais frações, embora verificadas, não sofreram nenhum tipo de ajuste, de tal forma que a composição granulométrica dos corpos-de-prova encontra-se na Erro! Fonte de referência não encontrada. e reflete a ranulometria original de campo.

\subsubsection{Fíler ativo}

As misturas recicladas avaliadas em laboratório receberam adição de cimento Portland, em teor de $1 \%$ em peso. É importante relembrar que os agregados fresados utilizados continham fíler (cal ou cimento) já considerados inertes nesta etapa de produção de misturas em laboratório. Os agregados foram todos misturados e quarteados, independente de ter cal ou cimento, já que estes foram 
considerados inertes. $O$ processo de adição é realizado para assegurar homogeneidade através de misturação; esta etapa antecede à adição de água de molhagem. Para garantir que o cimento esteja em condições perfeitas de aplicação, este é submetido a peneiramento na peneira $N^{\circ} 200$ (Figura 12).
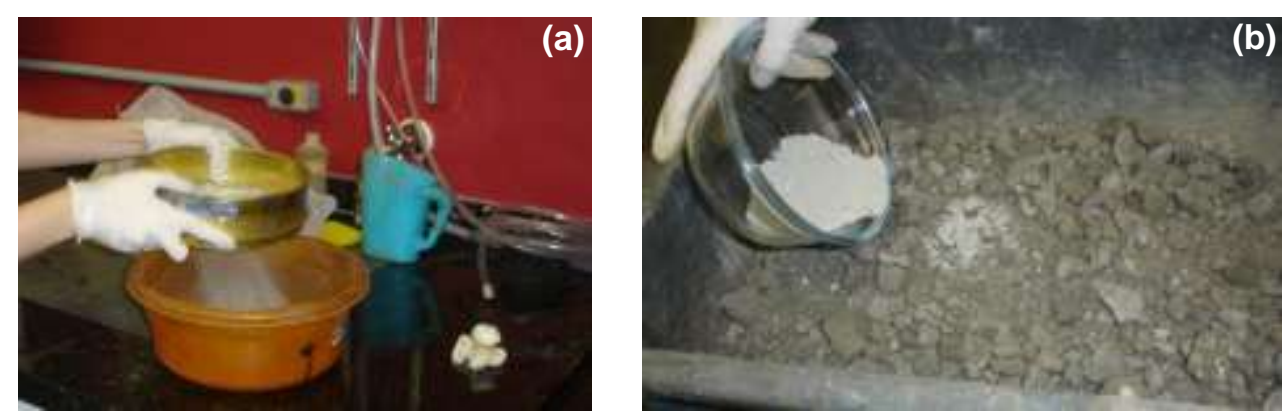

Figura 12 - Peneiramento (a) e adição de cimento na mistura reciclada (b)

\subsubsection{Teor de Umidade}

Inicialmente foram moldados corpos-de-prova seguindo a dosagem Marshall para misturas a frio, variando-se o teor de umidade entre $2 \%, 3 \%, 4 \%$ e $5 \%$, e fixando-se o teor de emulsão em 3,5\%. O objetivo da dosagem foi nortear o teor de umidade utilizado na seleção do teor ótimo de emulsão. Os resultados de volume de vazios e densidade aparente para os corpos de prova com variação de umidade encontramse na Figura 13.

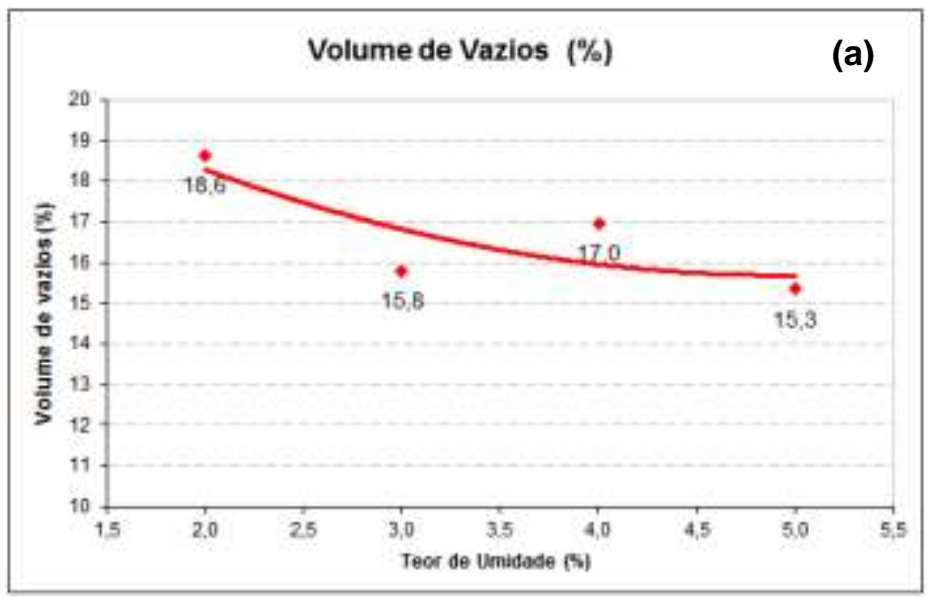




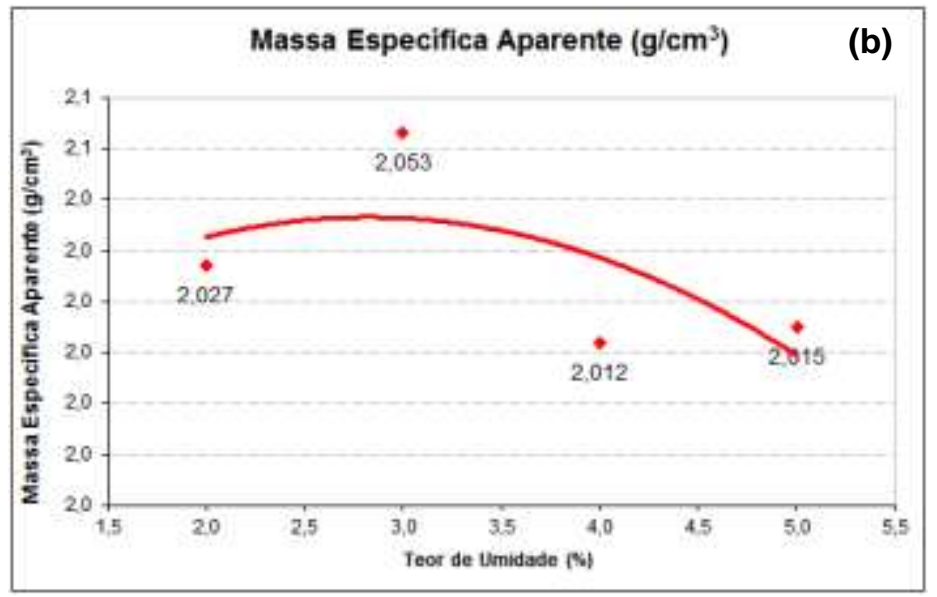

Figura 13 - Resultado das medidas de volume de vazios (a) e massa especifica aparente (b), dosagem Marshall - versus teor de umidade

Santana (1993) indica procedimentos experimentais para definição do teor de umidade, antes do processo de dosagem, que identifiquem visualmente trabalhabilidade e envolvimento do material. FHWA (2002), entretanto, indica a realização de dosagem preliminar para esta determinação; portanto a partir destes resultados da dosagem Marshall preliminar (com variação de umidade), definiu-se como teor de umidade para o processo de dosagem de emulsão o valor de $3 \%$ em massa (Figura 14).
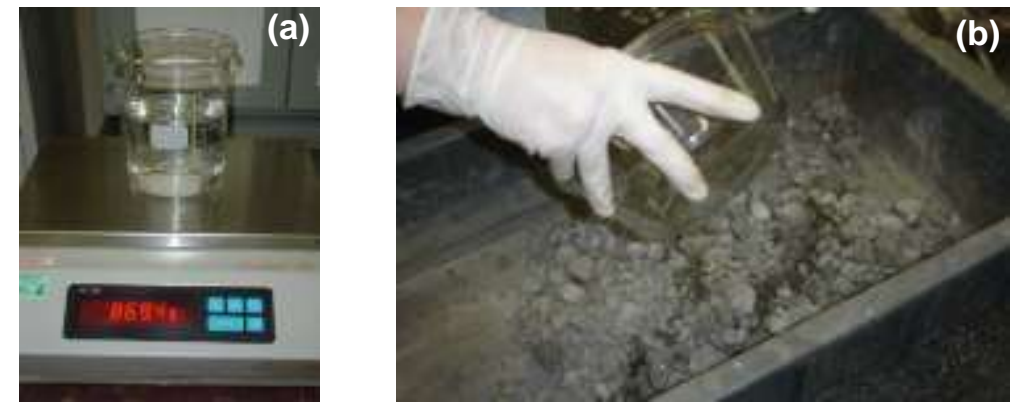

Figura 14 - Pesagem (a) e Adição de água na mistura reciclada (b)

\subsubsection{Teores de emulsão}

Para a determinação do teor ótimo foram selecionados cinco teores de emulsão asfáltica, com variação em 0,5\%: 2,5\%, 3,0\%, 3,5\%, 4,0\% e 4,5\%. É importante lembrar que a emulsão asfáltica é composta por uma parcela de água, e na moldagem dos corpos-de-prova são adicionados teores de água de molhagem antes 
da emulsão, de tal forma que no contato da emulsão com o agregado, este não extraia umidade da emulsão, iniciando precocemente o processo de ruptura.

Apesar da variação no teor de emulsão, não foram feitas ponderações no teor de umidade, permanecendo constante em $3 \%$; este fato implica na maior presença de água em misturas com maiores teores de emulsão (Figura 15).
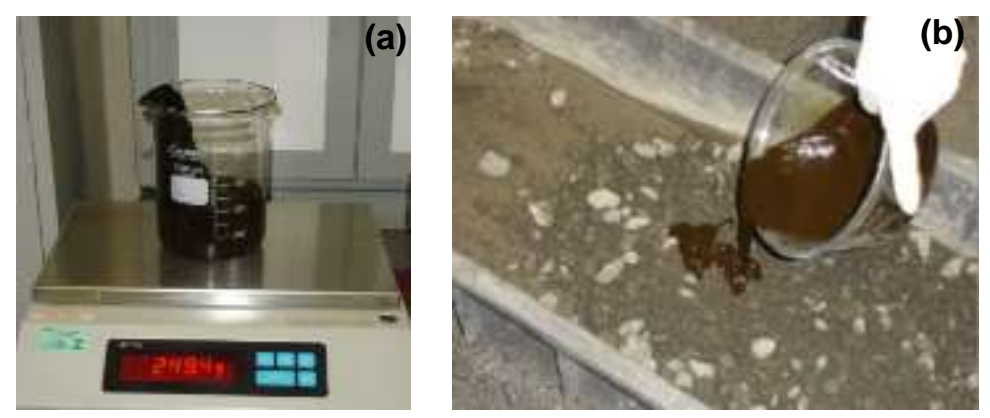

Figura 15 - Pesagem (a) e Adição de emulsão na mistura reciclada (b)

\subsubsection{Massa Específica Máxima Teórica}

As misturas recicladas passaram por processo de determinação da Massa Específica Máxima Teórica, seguinda as recomendações da norma (ASTM-D2041). O ensaio consiste na produção de mistura reciclada em condição solta, acondicionada em recipiente específico preenchido com água destilada e submetido à pressão de $30 \mathrm{mmHg}$, impingindo vácuo, de tal forma que os vazios sejam totalmente eliminados, permitindo a verificação da densidade máxima que a mistura atinge quando os vazios são totalmente preenchidos (Figura 16). As medidas de Densidade Máxima Teórica são utilizadas na determinação do volume de vazios.
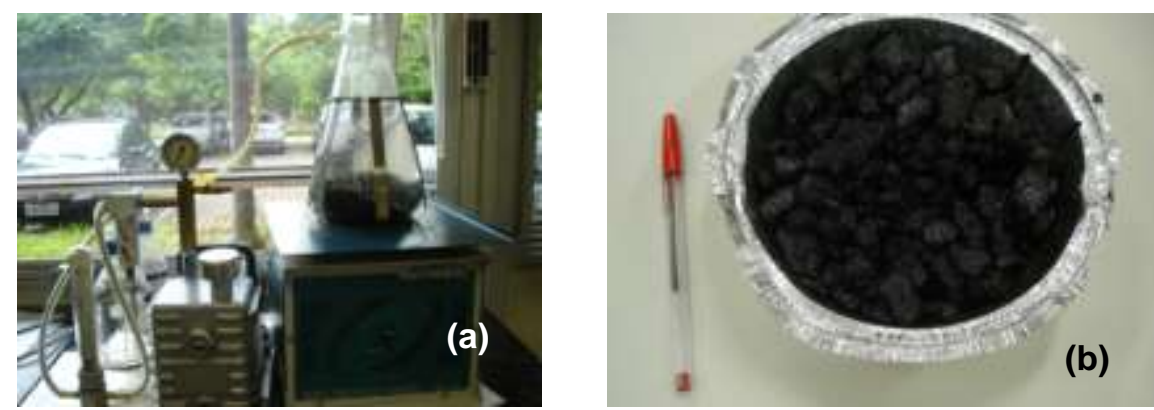

Figura 16 - Determinação da densidade máxima teórica - ensaio Rice (a), e amostra de mistura reciclada (b) 
Foram ensaiadas cinco amostras com os diferentes teores de emulsão utilizados na dosagem Marshall. Os resultados apresentados na Figura 17 revelam comportamento coerente, com decréscimo da densidade em função do aumento do teor de ligante.

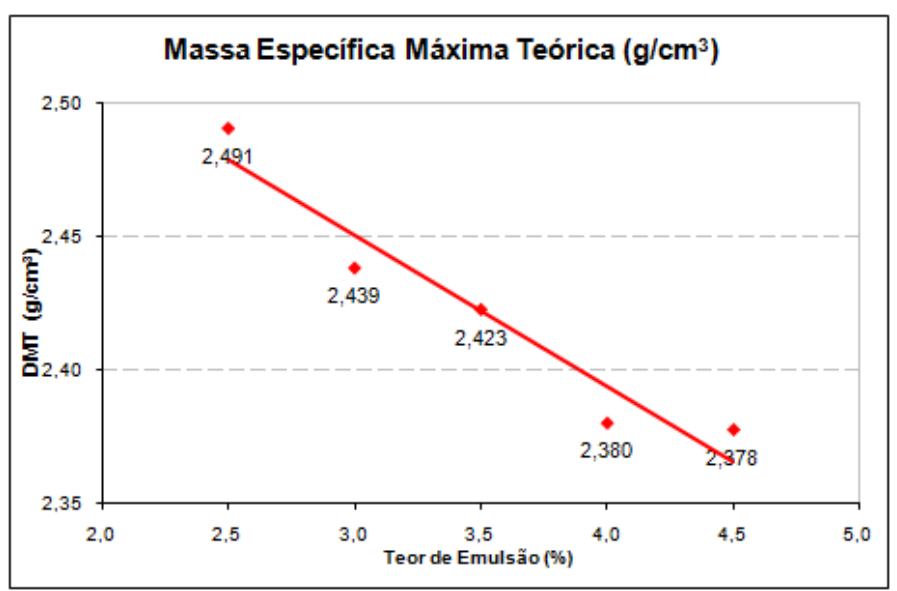

Figura 17 - Resultados da determinação da massa específica máxima teórica pelo ensaio Rice versus teor de emulsão modificada

\subsubsection{Massa Específica Aparente}

As medidas de densidade aparente dos corpos de prova foram realizadas inicialmente pelo método do paquímetro, a fim de se determinar a faixa de volume de vazios regular nesta mistura reciclada. Os resultados indicaram valores próximos de $19 \%$. Novas medidas foram então realizadas segundo a norma (DNER-ME117/94, 1994) utilizando o método da parafina, no qual o corpo de prova é selado por fita adesiva e então envolvido por camada de parafina, que impede a entrada de água (Figura 18).
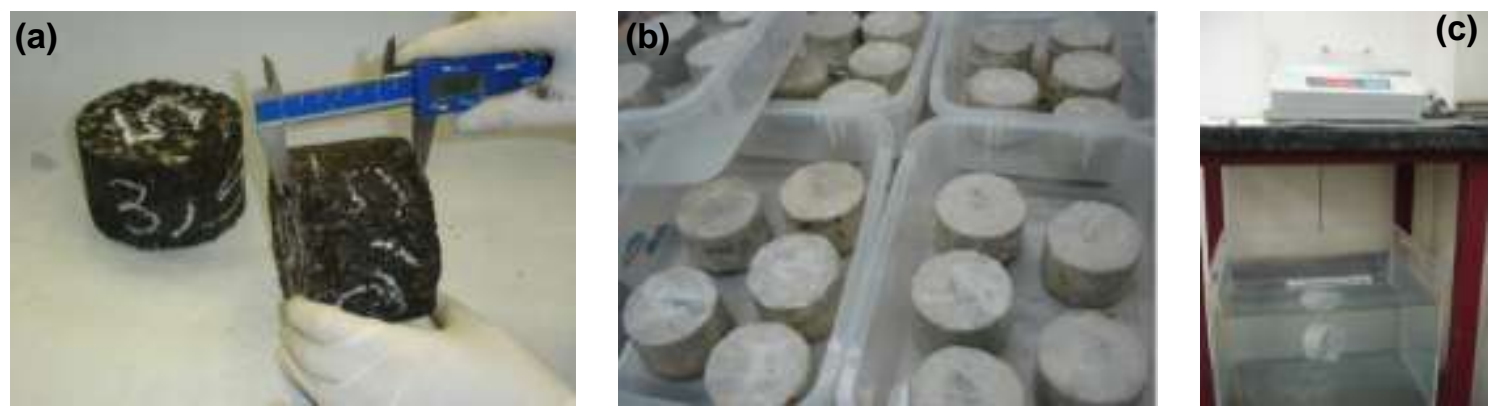

Figura 18 - Métodos de determinação da massa específica aparente: paquímetro (a) e parafina (b) e (c) 
Os resultados apresentados no gráfico sugerem comportamento da mistura reciclada similar a misturas convencionais; entretanto as variações em função do teor de emulsão foram muito discretas, fator que pode estar associado à composição da emulsão, por água e cimento asfáltico de petróleo, que após a cura tem teores de ligante residuais relativamente próximos, apesar da variação nos teores de emulsão (Figura 19).

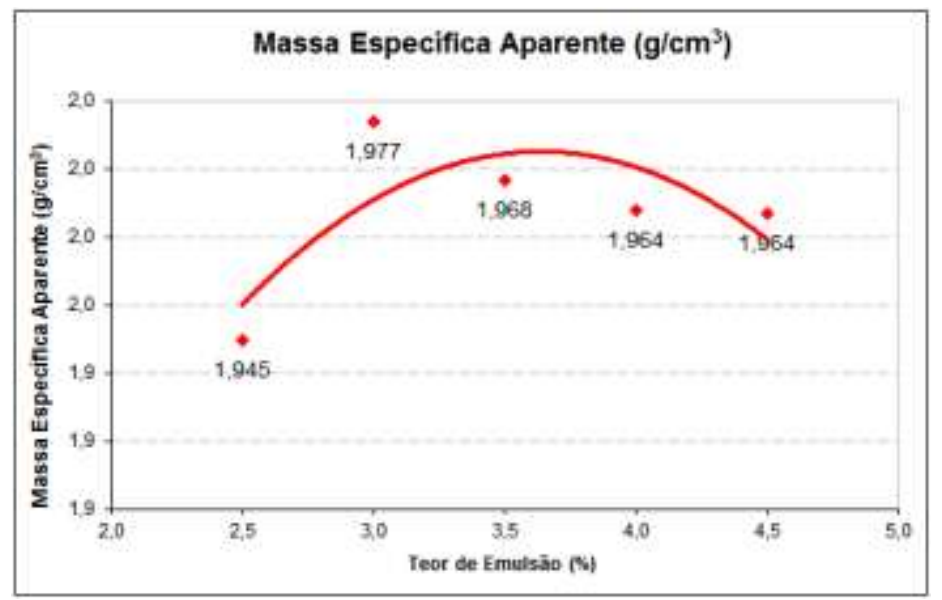

Figura 19 - Resultados de peso específico aparente versus teor de emulsão modificada

\subsubsection{Volume de Vazios}

O volume de vazios foi calculado em função dos resultados de medidas de Massa Específica Máxima Teórica (DMT) e de Massa Específica Aparente (Gmb), através da Eq. (1):

$$
\text { Volume de Vazios }=\frac{D M T-G m b}{D M T}
$$

Os resultados encontrados (Figura 20) são similares aos registrados na bibliografia, ratificando a necessidade de colocação de camada superficial selante, que impeça o acesso da água à camada com a mistura reciclada, uma vez que misturas com maior volume de vazios são mais susceptíveis à ação deletéria da água. 


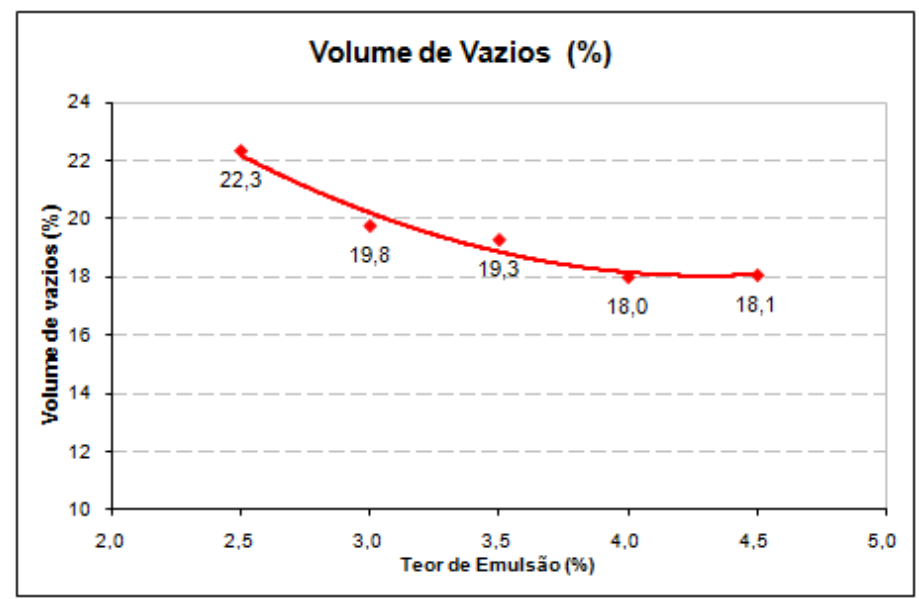

Figura 20 - Volume de vazios versus teor de emulsão modificada

Os maiores teores de emulsão conduzem à diminuição do volume de vazios de forma considerável, variando em até $4 \%$ de vazios, que pode ser resultado do alto teor de fluido na mistura, uma vez que não foram realizados estudos para ponderação do teor de água em função do teor de umidade. Como efeito da variação do teor de emulsão e teor fixo de água tem-se como exemplo ilustrativo que em misturas com teor de emulsão em $4,5 \%$ e teor de $3 \%$ de água, tem-se um total de $7,5 \%$ de fluido. Em misturas com teor de emulsão de 2,5\% e com 3\% do teor de água, soma-se um total de 5,5\%. A variação na proporção entre emulsão e água pode interferir no volume de vazios da mistura.

\subsubsection{Estabilidade}

O ensaio de estabilidade foi realizado de acordo com a norma DNER-ME 107/1994, que determina o procedimento para a realização do ensaio em misturas a frio. Os corpos de prova depois de compactados e curados (por 24 horas em estufa à temperatura de $60^{\circ} \mathrm{C}$ seguido de 2 horas ao ar à temperatura de $25^{\circ} \mathrm{C}$ ), são submetidos à temperatura de $40{ }^{\circ} \mathrm{C}$ em estufa por período de duas horas e então são ensaiados em molde de compressão próprio da prensa de aplicação de carga (Figura 21). 

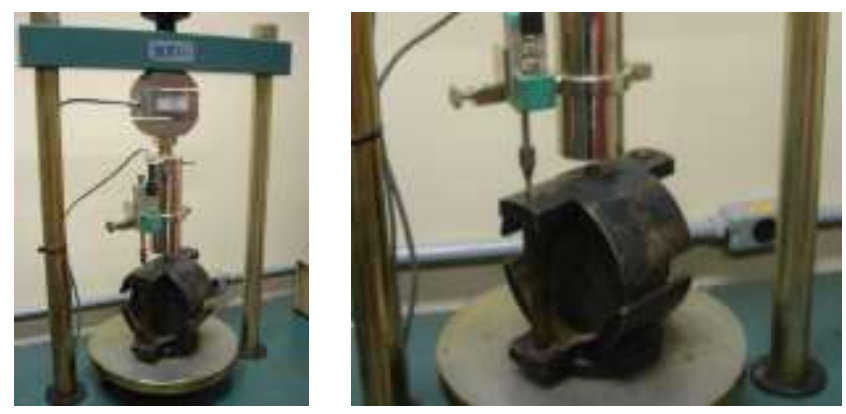

Figura 21 - Equipamento e ensaio de estabilidade

Não existem limites definidos para a estabilidade de misturas recicladas de forma que se procurou comparar os resultados desta pesquisa, com resultados de outros autores. Os resultados encontram-se resumidos na Figura 22.

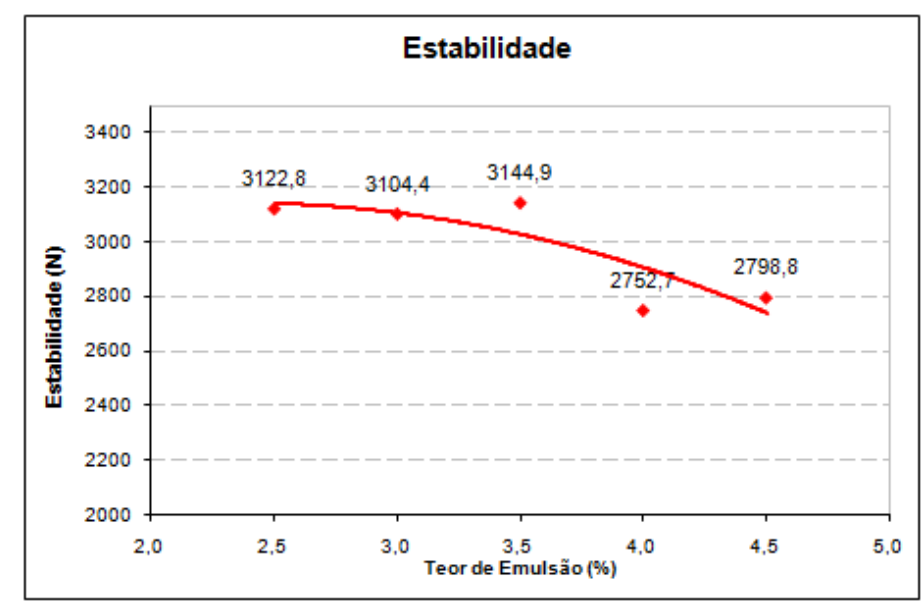

Figura 22 - Estabilidade Marshall x Teor de Emulsão

Os valores são relativamente baixos, nesta comparação. David (2006) encontrou valores entre $6.000 \mathrm{~N}$ e $9.000 \mathrm{~N}$, enquanto nesta pesquisa, variaram entre $2.700 \mathrm{~N}$ e $3.200 \mathrm{~N}$. Os valores mais baixos desta pesquisa podem ser resultado de períodos de cura mais curtos ( 2 horas à temperatura de $25^{\circ} \mathrm{C}$ ) após a cura regulamentar em estufa (24 horas à temperatura de $60^{\circ} \mathrm{C}$ ). $\mathrm{O}$ valor mínimo definido pelo (DNIT031/2006-ES, 2006) para concreto asfáltico a quente é de $5.000 \mathrm{~N}$. 


\subsubsection{Teor de Emulsão e Teor de Água Selecionado}

No projeto de dosagem o teor ótimo de água foi definido por experimentação e fixado em 3,0\% para todos os teores de emulsão avaliados. O teor ótimo de emulsão foi definido em 3,0\%, porém esse teor pode sofrer alguma variabilidade em campo, podendo chegar a $3,5 \%$.

\subsection{Propriedades Mecânicas}

A mistura reciclada foi submetida a ensaios convencionais de comportamento mecânico, para definição de padrões mínimos de desempenho em campo. As misturas avaliadas por meio destes ensaios se concentraram nos teores próximos do teor ótimo de emulsão aplicado em campo (2,5\%, 3,0\% e 3,5\%), prevendo alguma eventual variabilidade durante a execução em pista.

\subsubsection{Resistência à Tração por Compressão Diametral}

O ensaio de Resistência à Tração é padronizado sob a norma DNER-ME 138/1994, executado a temperatura de $25^{\circ} \mathrm{C}$, a partir da aplicação de carga vertical, distribuída numa barra, e promove a ruptura diametral do corpo-de-prova por tração (Figura 23).
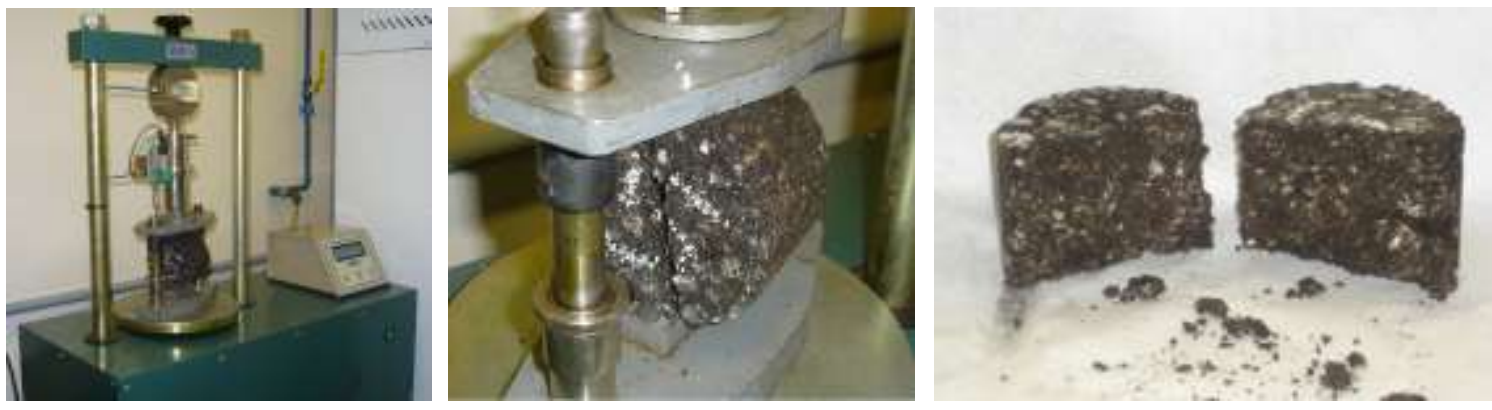

Figura 23 - Ensaio de resistência à tração por compressão diametral

Em função da dosagem Marshall, onde foi estabelecido o teor ótimo de emulsão em $3 \%$, foram moldados corpos de prova em três teores, 2,5\%,3,0\% e 3,5\% de emulsão modificada por polímero e $3 \%$ de água (pré-fixado) para os ensaios de resistência à tração, os resultados são apresentados na Figura 24. 


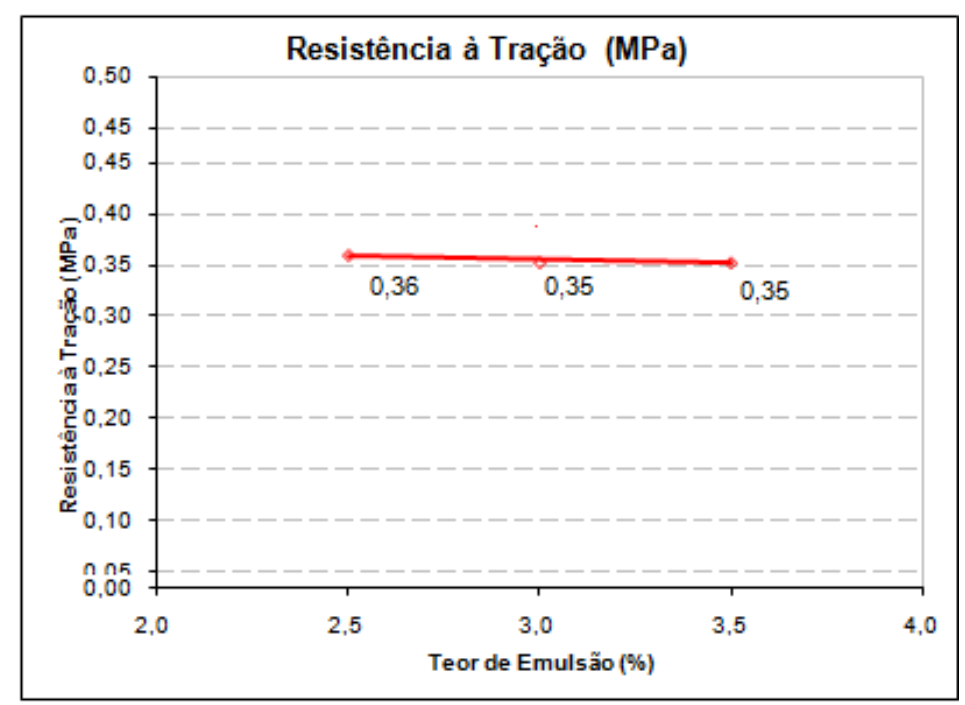

Figura 24 - Resultados de ensaios de resistência à tração para os teores de emulsão modificada

Os resultados para os três teores ensaiados foram muito parecidos, sem diferença estatística (teste t), para cinco amostras de cada condição. David (2006) apresenta resultados similares, porém com maior dispersão nos resultados para os mesmos teores de emulsão convencional.

\subsubsection{Dano por Umidade Induzida}

O ensaio (ASTM-D1075) mensura eventuais problemas de adesividade e de coesão, sob a ação deletéria da água. Os corpos de prova são submetidos a um banho por 24 horas à temperatura de $60^{\circ} \mathrm{C}$ e, em seguida são acondicionados em banho de água à temperatura de $25^{\circ} \mathrm{C}$ por duas horas (Figura 25), após as quais se procede 0 ensaio de resistência à tração por compressão diametral. 

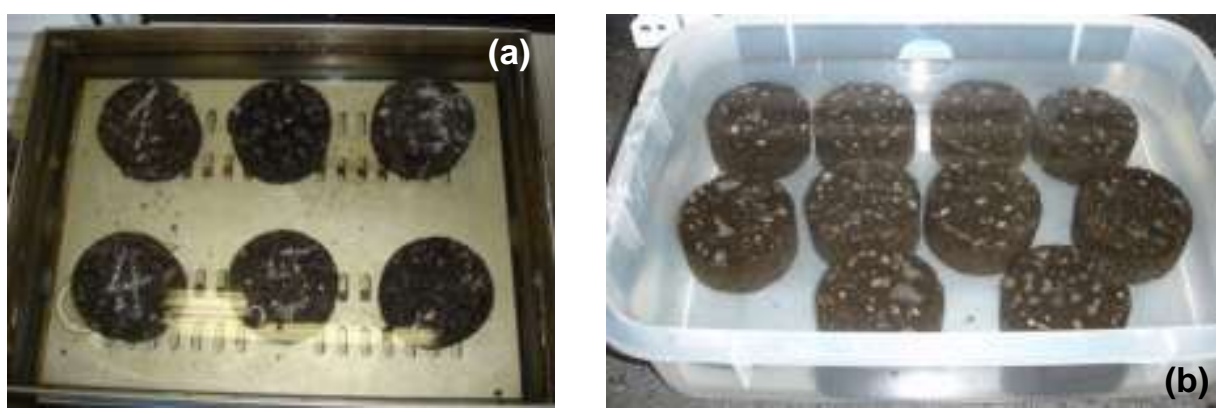

Figura 25 - Banho a $60^{\circ} \mathrm{C}$ (a) e a $25^{\circ} \mathrm{C}$ (b) para o ensaio de perda por umidade induzida

Os resultados são então comparados com medidas de resistência à tração de corpos de prova idênticos em teores de água, emulsão e moldagem, mas sem nenhum tipo de condicionamento após o período regular de cura em estufa. Os resultados médios são apresentados na Tabela 8, para os teores de emulsão ensaiados.

Tabela 8 - Resultados dos ensaios de resistência à tração em amostras com e sem condicionamento

\begin{tabular}{|c|c|c|c|}
\cline { 2 - 4 } \multicolumn{1}{c|}{} & \multicolumn{3}{c|}{ Emulsão Polímero } \\
\hline Teores & $\begin{array}{c}\text { RT (MPa) } \\
\text { Resistência à Tração } \\
\text { S/ condicionamento }\end{array}$ & $\begin{array}{c}\text { RRT (MPa) Resistência } \\
\text { à Tração Retida } \\
\text { C/ condicionamento }\end{array}$ & $\begin{array}{c}\text { Dano por } \\
\text { Umidade } \\
\text { Induzida } \\
(\%)\end{array}$ \\
\hline 2,5 & 0,36 & 0,22 & 37,5 \\
\hline 3,0 & 0,35 & 0,25 & 28,3 \\
\hline 3,5 & 0,35 & 0,25 & 28,2 \\
\hline
\end{tabular}

O resultado mais baixo para mistura com menor teor de emulsão $(2,5 \%)$ pode ter sido decorrente do menor recobrimento dos agregados e menor coesão. A água adicionada para facilitar a distribuição e compactação pode também interferir na interação entre o agregado e o resíduo da emulsão. O excesso de água pode impedir fisicamente que o filme asfáltico se forme bem aderido ao agregado, reduzindo assim a coesão da mistura e, por conseguinte impactando nos resultados de ensaios de propriedades mecânicas.

\subsubsection{Módulo de Resiliência Triaxial}

O ensaio de Módulo de Resiliência foi executado em laboratório baseando-se na norma (DNER-ME-131/94, 1994), tratando como material granular a mistura 
reciclada. O principal objetivo foi verificar se da mesma forma que as camadas granulares, a tensão de confinamento exerce influência no comportamento da mistura. Para tanto, o corpo de prova foi moldado em cilindro apropriado nas dimensões de $10 \mathrm{~cm}$ de diâmetro por $20 \mathrm{~cm}$ de altura, compactado em cinco camadas, com energia intermediária (Figura 26). As tensões de confinamento aplicadas foram de 0,021 a 0,14 MPa.
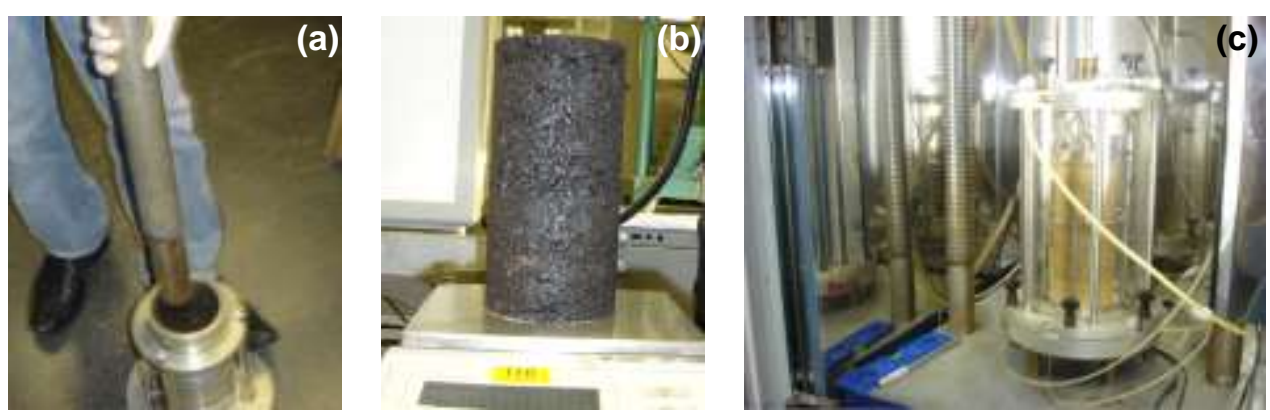

Figura 26 - Moldagem (a) e pesagem (b) de corpo-de-prova e ensaio de módulo de resiliência triaxial (c)

O ensaio foi realizado para corpos de prova no teor ótimo de emulsão e umidade, mas com variação no período de cura. O primeiro grupo foi ensaiado após 7 dias em que os corpos de prova foram mantidos em temperatura controlada de $25^{\circ} \mathrm{C}$, depois do período regular de cura em estufa (24 horas a $60^{\circ} \mathrm{C}$ ). O segundo grupo foi ensaiado após 28 dias de cura a $25^{\circ} \mathrm{C}$. O objetivo desta etapa é compreender a relação entre a cura e o comportamento mecânico, consideração contemplada na dosagem realizada pelo DOT do Oregon, conforme mencionado no item 2.3. Desta forma pode-se verificar além do valor médio de módulo de resiliência, a influência da extensão do período de cura (Figura 27). 


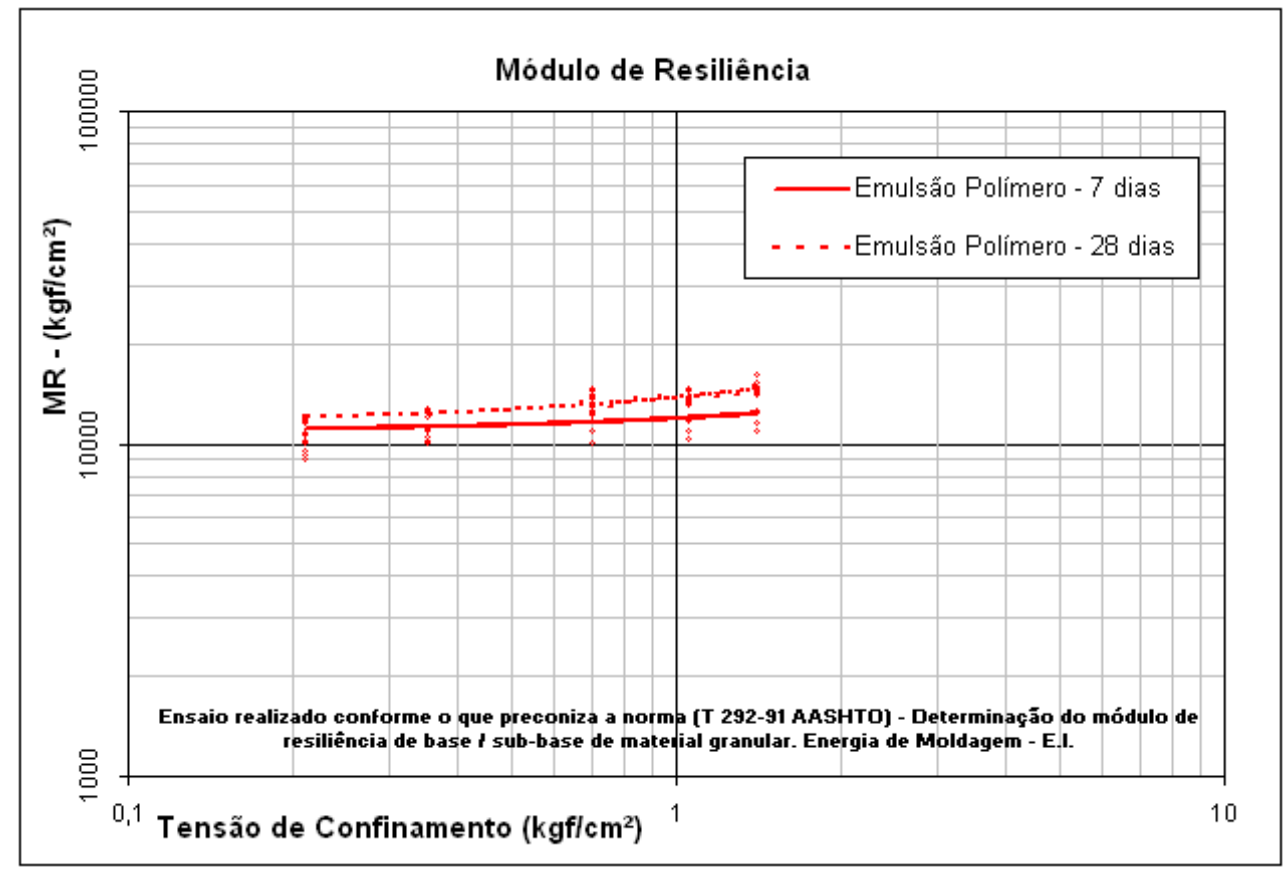

Figura 27 - Módulo de resiliência de amostras com variação no período de cura

O ensaio triaxial revelou que, embora exista uma sensível influência do efeito da tensão de confinamento sobre misturas recicladas a frio, o comportamento desta camada na estrutura se difere de uma camada granular, não apenas pela baixa sensibilidade à tensão de confinamento, mas principalmente pelo módulo de resiliência maior do que 1.000 MPa. Nas condições dos materiais testados, o módulo de resiliência varia entre 1.100 a $1.500 \mathrm{MPa}$.

A comparação com misturas asfálticas convencionais também não é correta, pois a mistura reciclada não apresenta a mesma coesão que concretos asfálticos a quente, fato que se percebe pela pequena, mas existente sensibilidade à tensão de confinamento nas misturas recicladas, ao passo que o concreto asfáltico usinado a quente não apresenta tal influência.

\subsection{Comparativo entre Misturas Recicladas com Diferentes Emulsões}

Esta pesquisa utilizou emulsão modificada por polímero SBS como ligante asfáltico, por benefícios associados ao uso do polímero. As emulsões convencionais foram utilizadas em laboratório, de modo a estabelecer comparação entre misturas 
recicladas com os dois tipos de emulsão (convencional e polímero) e verificar tendências de comportamento de ambas.

Foram moldados corpos de prova para dosagem Marshall com emulsão convencional, da mesma forma e com as mesmas variações nos teores de emulsão modificada por polímero, em acordo com a norma DNER-ME 107/94. Os resultados permitem a comparação entre as misturas com os dois tipos de emulsão a partir das medidas de massa específica aparente e volume de vazios e são apresentados na Figura 28 e na Figura 29; indicam tendência de comportamento e valores absolutos similares entre as misturas recicladas com emulsão modificada por polímero e com emulsão convencional. O teor ótimo obtido pela dosagem Marshall foi igual para as misturas com as duas emulsões. Os resultados eram esperados uma vez que a quantidade de fluido é parecida em ambas as misturas, e o processo de densificação é função direta da quantidade de água e de emulsão nas misturas.

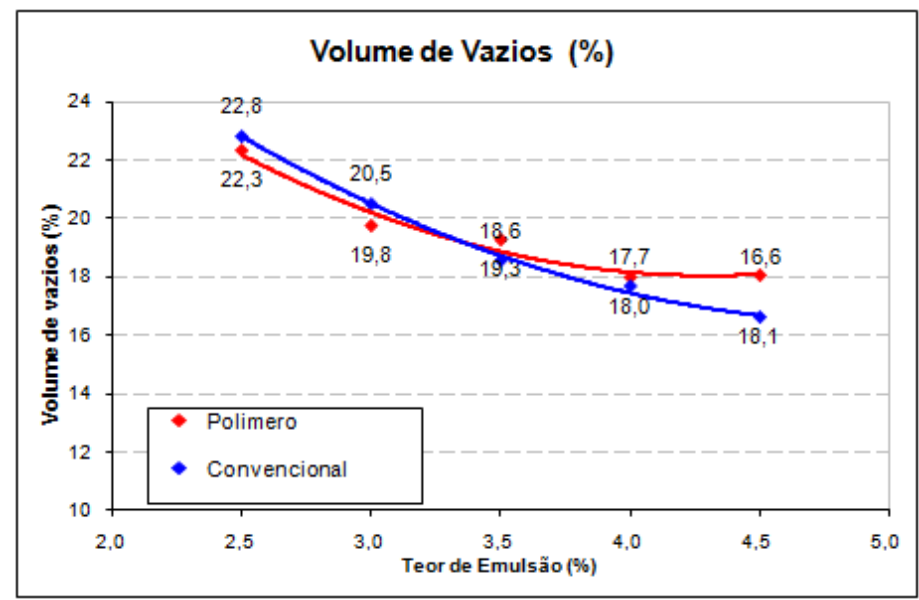

Figura 28 - Comparativo de volume de vazios

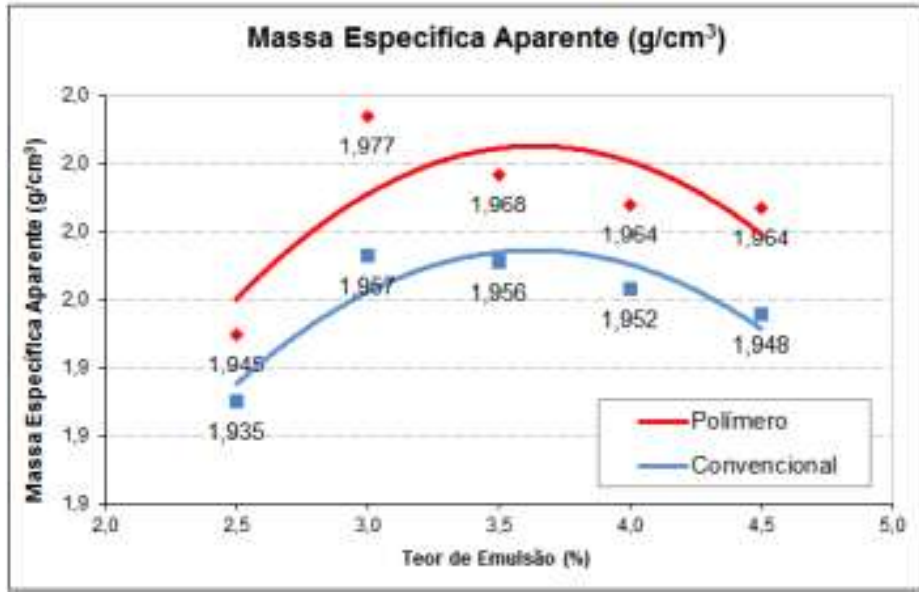

Figura 29 - Comparativo de massa específica aparente 
Os parâmetros volumétricos associados à dosagem Marshall revelaram diferença pouco expressiva atribuída às emulsões. As pequenas variações encontradas podem estar mais relacionadas à variabilidade dos materiais agregados fresados, do que às emulsões avaliadas.

Durante os trabalhos de misturação, compactação e extração de corpos de prova em laboratório, identificou-se visualmente melhor trabalhabilidade nas misturas recicladas com emulsão modificada por polímero, resultando em corpos de prova com aspecto mais homogêneo.

Também foram realizados ensaios de comportamento mecânico para as misturas recicladas com emulsão convencional, permitindo estender a comparação entre as duas misturas. Estes ensaios foram realizados apenas com variação de três teores de emulsão $(2,5 \%, 3,0 \%$ e 3,5\%), em função do teor ótimo obtido na dosagem, uma vez que o teor ótimo está em torno de 3,0\%.

Os ensaios de resistência à tração foram realizados em duas condições: sem condicionamento e com condicionamento, de forma a se obter os valores de perda por umidade induzida. Os corpos-de-prova sem condicionamento, após moldagem, passaram por processo de cura regulamentado (24 horas a temperatura de $40^{\circ} \mathrm{C} \mathrm{e}$ permaneceram por 14 dias em temperatura controlada de $25^{\circ} \mathrm{C}$ até a realização do ensaio). Os corpos de prova com condicionamento passaram pelo mesmo período de cura que àqueles sem condicionamento, após o qual foram mantidos em banho a $60^{\circ} \mathrm{C}$ por 24 horas, seguido de banho a $25^{\circ} \mathrm{C}$ por 2 horas, sendo ensaiado em seguida. Os resultados de resistência à tração e resistência à tração retida encontram-se na Figura 30. 


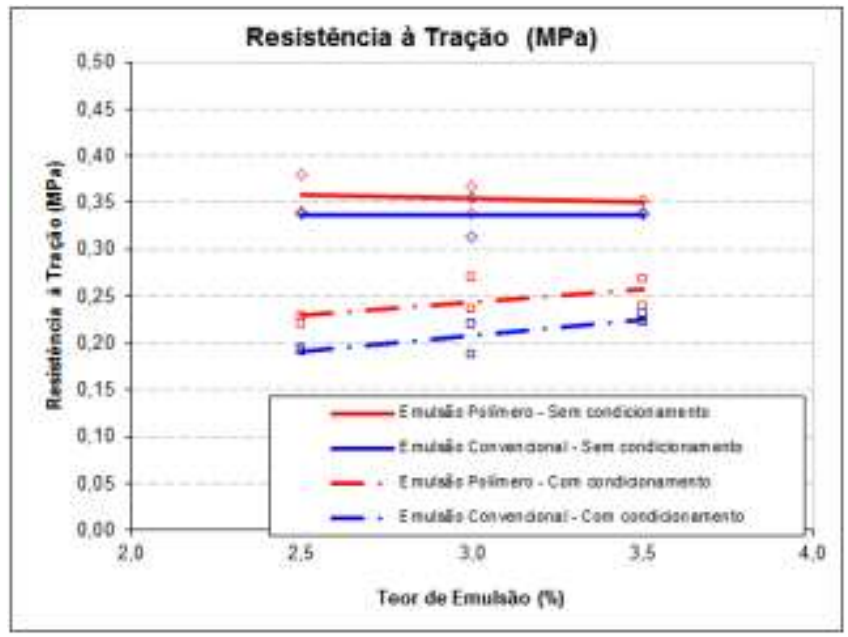

Figura 30 - Resistência à tração com e sem condicionamento

Os valores de resistência à tração em misturas recicladas com emulsão modificada por polímero são relativamente mais altos do que as misturas com emulsão convencional, tanto os não condicionados, quanto os condicionados. A superioridade dos resultados para misturas com polímero é esperada, uma vez que a incorporação de polímero incrementa a resistência à ação deletéria da água; o resultado pode estar diretamente relacionado à rede ou malha formada sobre o filme de emulsão asfáltica, que amortece as tensões efetivas sobre o ligante asfáltico.

Os resultados de resistência à tração retida são na Figura 31. De acordo com Liberatori (2005), o ensaio de perda por umidade induzida tem grande importância para as misturas recicladas a frio com emulsão, sendo que a emulsão com polímero deve apresentar resultados elevados que mostram a adequação da mistura quanto à adesividade e coesão inicial propiciada pelo ligante modificado.

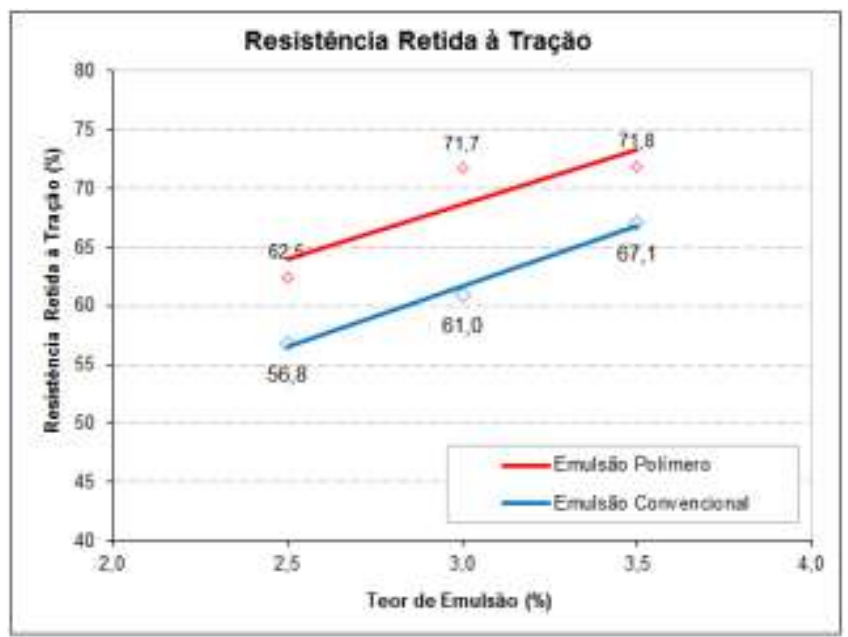

Figura 31 - Comparativo de perda por umidade induzida 
Os resultados de perda por umidade induzida mostraram coeficiente de variação maior sempre em misturas com emulsão convencional (Tabela 9); a emulsão modificada por polímero mostrou anteriormente melhores propriedades de dispersão e recobrimento, garantindo menor variabilidade no comportamento mecânico.

Tabela 9 - Perda por umidade induzida nas misturas com emulsão convencional e com emulsão modificada por polímero

\begin{tabular}{|c|c|c|}
\hline \multicolumn{3}{|c|}{ Perda por Umidade Induzida (\%) } \\
\hline $\begin{array}{c}\text { Teor de } \\
\text { Emulsão }\end{array}$ & $\begin{array}{c}\text { Emulsão } \\
\text { Polímero }\end{array}$ & $\begin{array}{c}\text { Emulsão } \\
\text { Convencional }\end{array}$ \\
\hline 2,5 & 37,5 & 43,2 \\
\hline 3,0 & 28,3 & 39,0 \\
\hline 3,5 & 28,2 & 32,9 \\
\hline
\end{tabular}

O ensaio Cântabro, que avalia o desgaste do corpo de prova Marshall no tambor Los Angeles, é um ensaio bastante severo que foi realizado com as misturas recicladas em seus teores ótimos de emulsão e umidade (Figura 32). Para cada mistura foram moldados 10 corpos de prova, sendo que cada um é submetido a 200 rotações do tambor, com as pesagens do corpo de prova realizadas antes e depois do ensaio. $\mathrm{A}$ diferença calculada, em porcentagem, não deve ser superior a $20 \%$ para misturas abertas, a quente (DNER-ME-383/99, 1999). Não há valor normatizado para o ensaio Cântabro para misturas a frio.
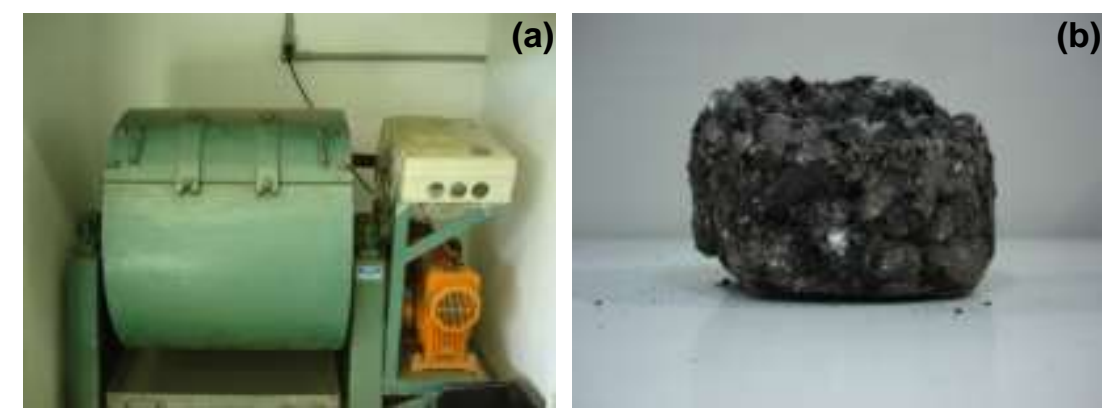

Figura 32 - Tambor Los Angeles (a) e aspecto do corpo-de-prova após ter sido submetido a 200 rotações

Os resultados médios indicados na Tabela 10 mostram diferença entre as duas emulsões, entretanto a ordem de grandeza da porcentagem de perda do ensaio indica comportamento similar entre as misturas apesar de relativo destaque da mistura reciclada com emulsão modificada por polímero. Os resultados mais 
favoráveis das misturas com polímero podem estar associados à maior coesão inicial prevista como benefício pela incorporação de polímero.

Tabela 10 - Resultados de perda no ensaio Cântabro para as misturas comparadas

\begin{tabular}{|c|c|}
\hline \multirow{2}{*}{ Tipo de Emulsão } & $\begin{array}{c}\text { Perda } \\
\text { Cântabro }\end{array}$ \\
\cline { 2 - 2 } & $\%$ \\
\hline Emulsão Polímero & 17,8 \\
\hline Emulsão Convencional & 20,2 \\
\hline
\end{tabular}

Deve-se ressaltar que este ensaio é bastante severo para misturas a frio, e que a coesão da mistura compactada por impacto é muito menor do que misturas compactadas por amassamento (similar à compactação de campo). Moreira (2005) executou o ensaio Cântabro em misturas recicladas a frio compactadas por impacto e por amassamento, e encontrou resultados mais coerentes para aquelas compactadas por amassamento, revelando justamente que a coesão propiciada pelo método de compactação associado ao uso do polímero pode ser determinante para a obtenção de resultados mais coerentes com desempenhos verificados em campo.

\subsection{Características dos Materiais Empregados como Camada de Revestimento}

O trecho experimental dividido em seis segmentos recebeu concreto asfáltico como camada de revestimento em três segmentos e, microrrevestimento a frio em outros três segmentos. As características dos materiais destas camadas não foram avaliados em laboratório nesta pesquisa; contudo, suas propriedades, fornecidas pelas empresas executoras, são apresentadas nos itens 3.5.1 e 3.5.2.

\subsubsection{Concreto Asfáltico}

A camada de Concreto Betuminoso Usinado a Quente ( $C B \cup Q$ ), foi executada pela empresa Jorcal, com espessura de $4 \mathrm{~cm}$, numa extensão de 750 metros, formulada 
para a faixa granulométrica apresentada na Figura 33, sendo composta por Brita 1, Pedrisco, Pó-de-pedra e Cal CH - 1.

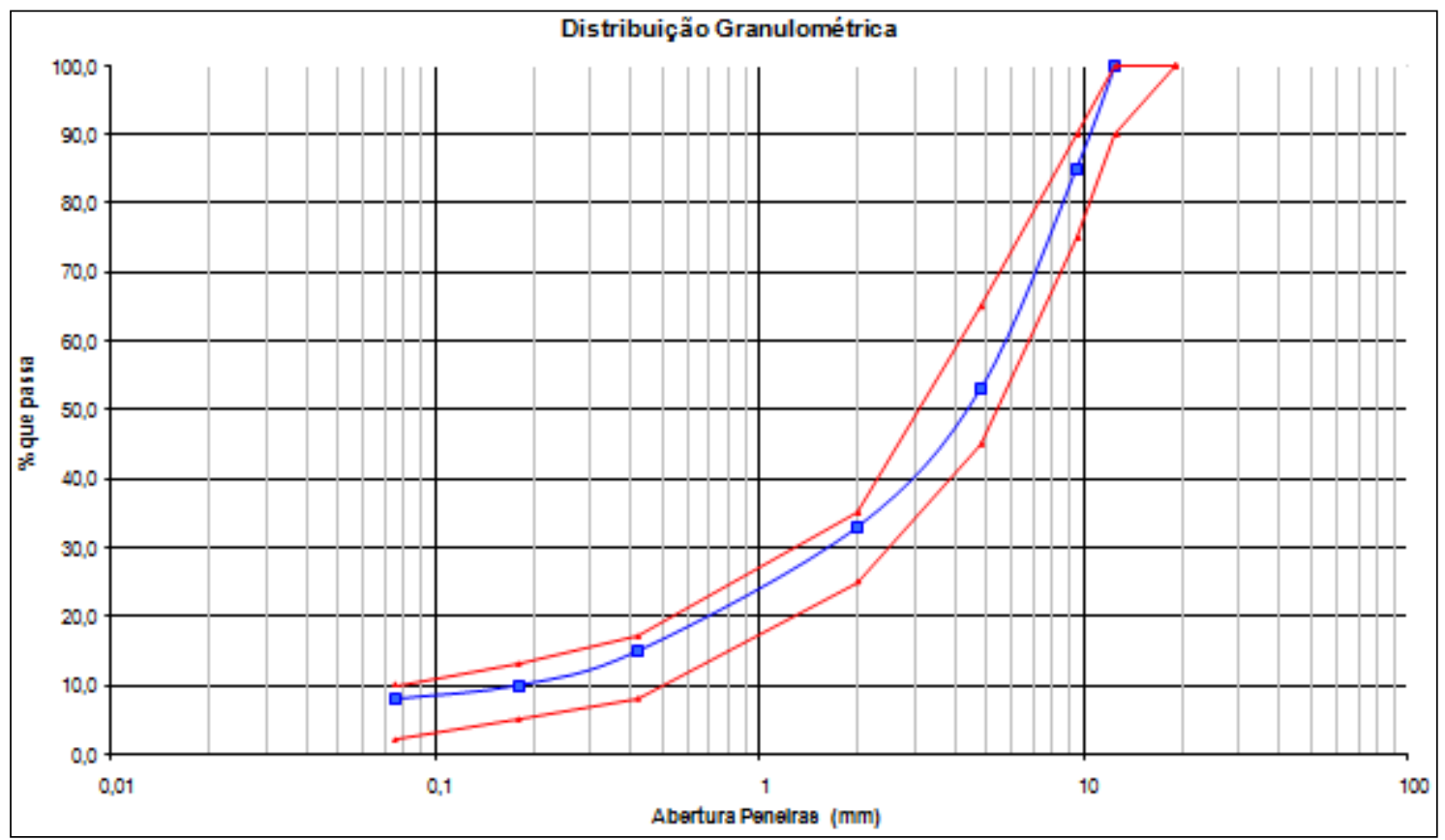

Figura 33 - Faixa granulométrica do CBUQ executado como camada de revestimento no trecho experimental

O ligante utilizado foi o tipo CAP 30/45, tendo variações entre os teores de $4,0 \%$ e $6,0 \%$, sendo definido como teor ótimo, 5,4\% de ligante. A Figura 34 apresenta os resultados de volume de vazios e peso específico aparente, medidos pela empresa executora, não tendo sido possível a realização de ensaios adicionais nesta pesquisa.
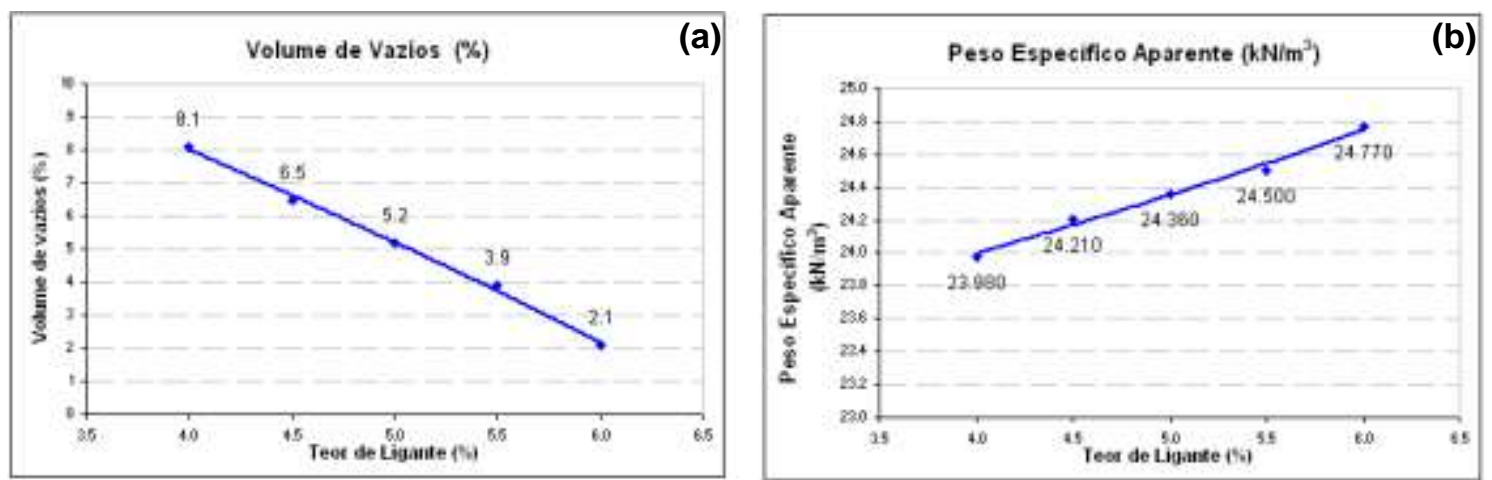

Figura 34 - Volume de vazios (a) e peso específico aparente do concreto asfáltico (b) 


\subsubsection{Microrrevestimento Asfáltico a Frio}

A camada de microrrevestimento asfáltico a frio, executada em duas camadas pela construtora Garcia Monteiro, em um total de $12 \mathrm{~mm}$ de espessura, numa extensão de 1500 metros, teve definida a faixa granulométrica apresentada na Figura 35 e composta por Pedrisco Fino, Pó-de-pedra e Cal CH-1.

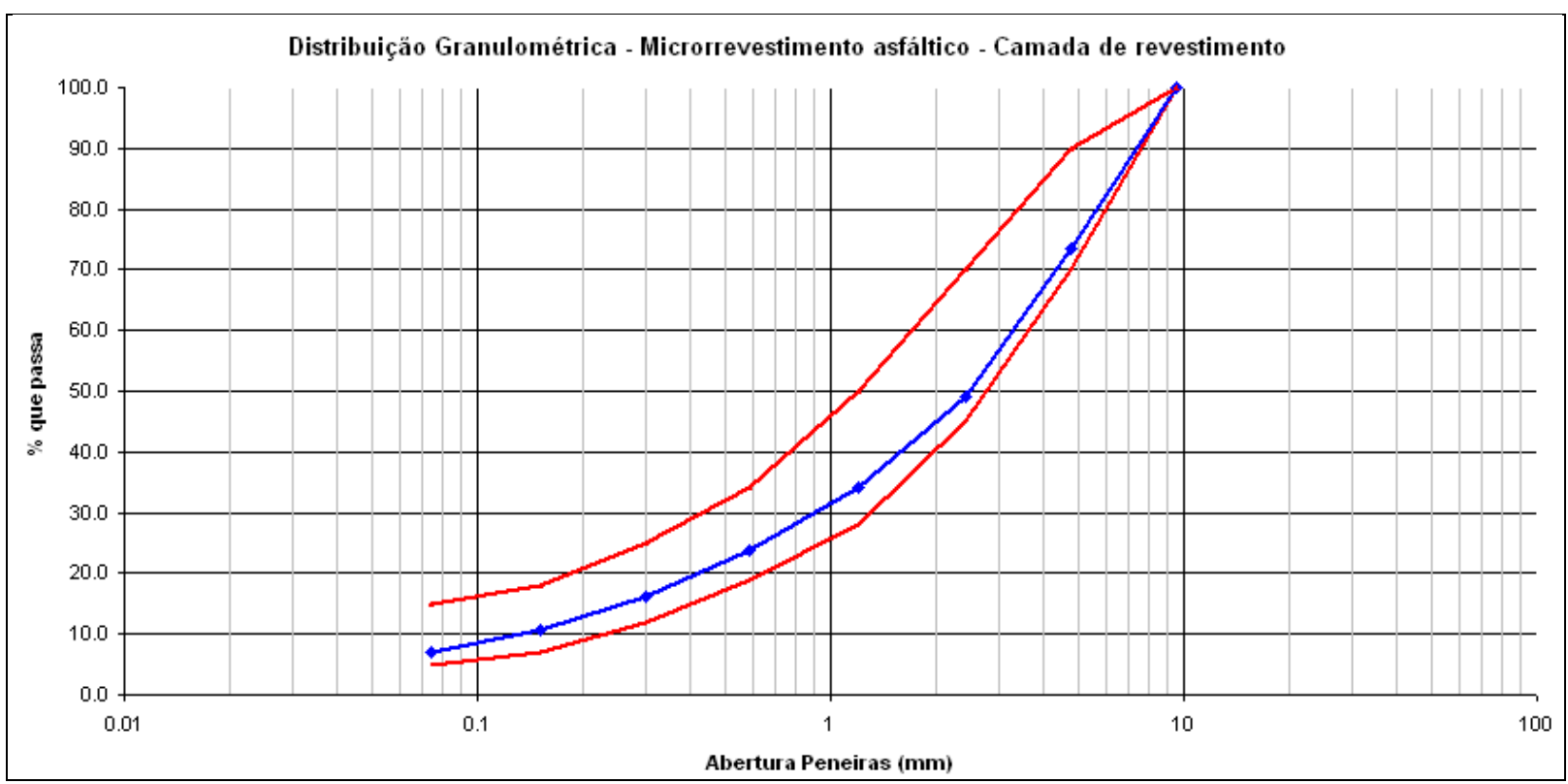

Figura 35 - Faixa granulométrica do microrrevestimento asfáltico a frio executado no trecho experimental

Os demais componentes da mistura são elencados na Tabela 11.

Tabela 11 - Componentes da mistura de microrrevestimento executado

\begin{tabular}{|c|c|c|}
\hline $\begin{array}{c}\text { Componente da } \\
\text { Mistura }\end{array}$ & $\begin{array}{c}\text { \% em relação aos } \\
\text { agregados }\end{array}$ & Tolerância \\
\hline Água de Molhagem & 8,7 & $+/-1,0$ \\
\hline Adiflex VO & 0,3 & $+/-0,3$ \\
\hline Emulex RL 1C & 9,4 & $+/-0,5$ \\
\hline \% CAP residual & 5,8 & $+/-0,3$ \\
\hline
\end{tabular}




\section{EXPERIMENTO DE CAMPO - RODOVIA RÉGIS BITTENCOURT}

\subsection{Objetivos do Experimento}

A técnica de reciclagem a frio in situ de pavimentos deteriorados, conforme abordado no capítulo 2, tem sido crescente e largamente utilizada em todo o mundo. O Brasil também tem registros de aplicação desta técnica, embora sem apresentar valores expressivos de utilização, como países europeus e norte-americanos. A experiência dos países desenvolvidos tem norteado o desenvolvimento e adaptação de procedimentos diferentes de laboratório e de campo, baseados na avaliação conjunta de projetos laboratoriais e de vias executadas.

O grande número de variáveis associadas à reciclagem, especialmente devido à variabilidade do material obtido dos pavimentos deteriorados, explica a dificuldade de fixação de procedimentos totalmente aceitos. Para ilustrar esta dificuldade, os EUA possuem diversos métodos adotados pelos Departamentos de Transporte, com base em suas experiências estaduais. Refinar processos de laboratório e de execução é considerado fundamental para a determinação de processos de reciclagem bem sucedidos.

Diante do exposto, a pesquisa apresentada nesta dissertação tem por objetivo avaliar os parâmetros envolvidos na restauração de trecho experimental, localizado na Rodovia Régis Bittencourt - BR 116 - trecho São Paulo - Curitiba, sentido norte, entre os quilômetros 433+000 e 435+750 na cidade de Registro - SP, sob concessão da AutoPista Régis Bittencourt, do Grupo OHL Brasil, que empregou a reciclagem a frio dos revestimentos deteriorados (Figura 36). 


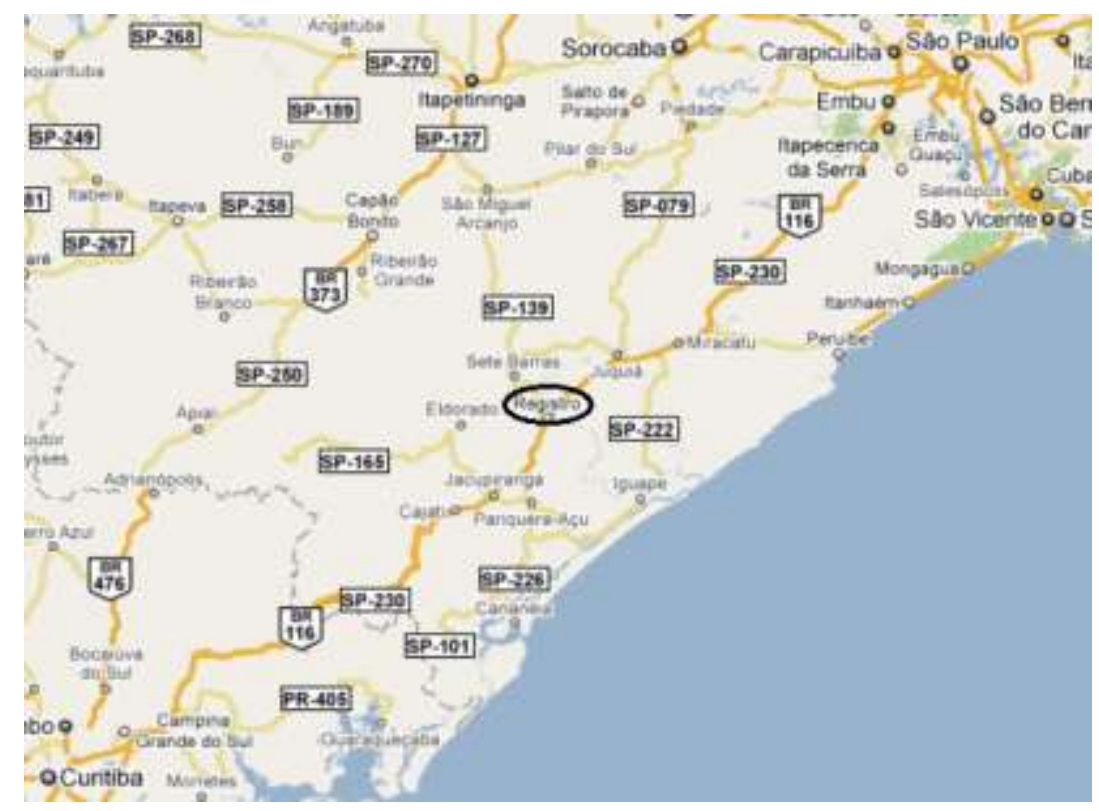

Figura 36 - Rodovia Régis Bittencourt entre São Paulo e Curitiba, sob concessão da Autopista Régis Bittencourt - Trecho experimental na cidade de Registro.

Tradicionalmente, restaura-se pavimentos deteriorados por meio de recapeamento, com ou sem fresagem da espessura trincada, prática que pode ser pouco eficiente, pois comumente desconsidera as causas dos defeitos superficiais; em oposição a este método, a proposta de reciclagem exige avaliação de todas as características da via, a fim de direcionar de forma coerente a técnica a ser implementada.

Foram consideradas, para a determinação da estratégia de restauração da via deteriorada, as seguintes características: qualidade da construção original, tipo e espessura das camadas, integridade e capacidade de suporte das camadas, tipo de subleito, fatores ambientais, tipo e eficiência de intervenções, e composição de carga e tráfego (ARRA, 2001).

\subsection{Características do Trecho Experimental}

\subsubsection{Histórico do Trecho Experimental}

O trecho escolhido possui características muito similares em termos de condições estruturais e funcionais, por toda a extensão de 2,250 km. A definição destas características é importante para inferir a condição de homogeneidade, dado fundamental ao projeto de reciclagem. Além disso, o trecho tem condições 
representativas dos problemas observados por levantamento visual contínuo por toda a rodovia, entre São Paulo e Curitiba, sentido Norte.

O trecho experimental integra a duplicação da Rodovia Régis Bittencourt, executado em 1998, então sob administração do extinto DNER (atual DNIT), portanto, denominada como a pista nova da Rodovia. O trecho definido como segmento homogêneo encontrava-se entre os km 431+250 e km 439+500, baseado na avaliação deflectométrica, em acordo com a normatização da DNER PRO 273/1996. A estrutura original, conforme representada esquematicamente na Figura 37, é composta por camada de rolamento de concreto asfáltico, camada intermediária, base de brita graduada simples e subleito.

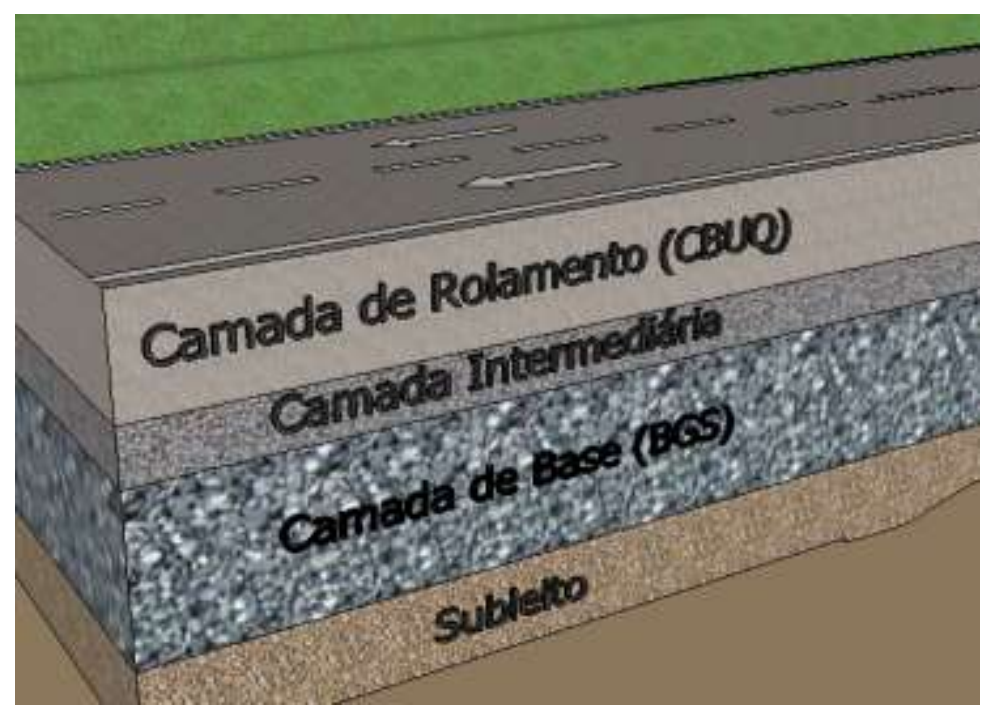

Figura 37 - Estrutura de pavimento existente no trecho experimental, antes da restauração

O projeto de restauração inicial, definido a partir do método DNER PRO 269/1994, estabeleceu a necessidade de $7,0 \mathrm{~cm}$ de camada de reforço em CBUQ. No dimensionamento de espessura de reforço pelo método DNER PRO 11/1979, definiu-se a necessidade de $6,5 \mathrm{~cm}$ de $C B \cup Q$.

O trecho não sofreu intervenções significativas com finalidade de manutenção ou restauração antes de sua concessão. Os principais defeitos encontrados neste segmento eram trincamento classe FC3 com erosão de borda e deformação permanente em trilha de roda. Foram também encontrados indicativos de drenagem deficiente, potencializando as dificuldades de dirigibilidade, afetando questões 
relativas à segurança e ao conforto ao rolamento. A camada de revestimento demonstra trincamento excessivo (Figura 38) e a mistura asfáltica existente não tinha problemas críticos de segregação.

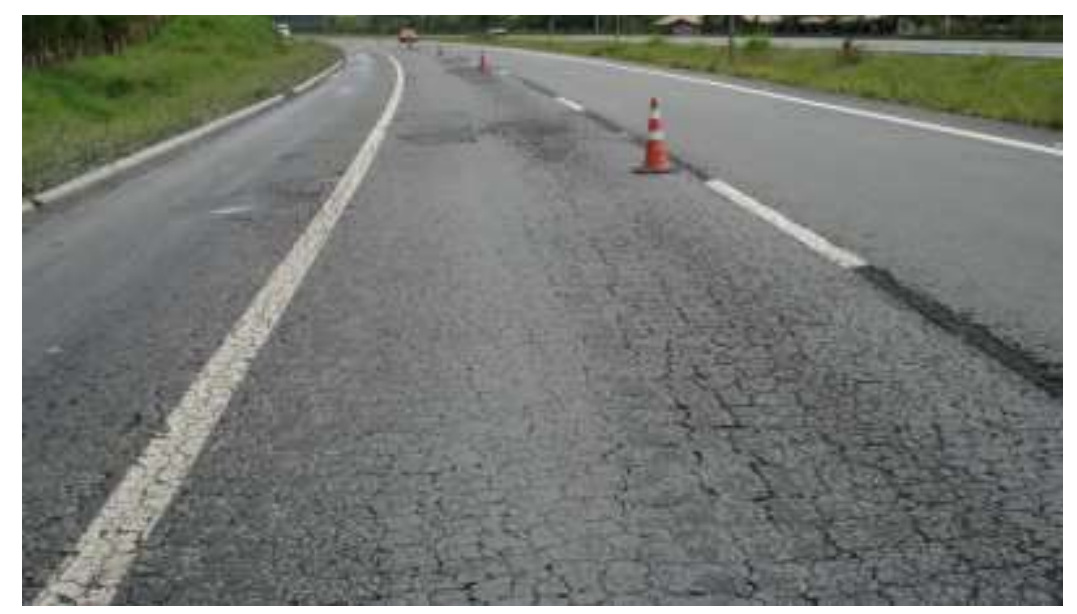

Figura 38 - Trincamento existente no trecho experimental antes da restauração

A deformação permanente em trilha de roda é um problema que afeta grande parte dos pavimentos asfálticos, sendo mais intensa em regiões de temperatura elevada e tráfego de veículos pesados e lentos, condição operante desta rodovia, conforme se verifica na Figura 39. Destaca-se o acúmulo de água na trilha de roda, agravando os problemas de drenagem. O trecho em rampa descendente (Figura 39), com inclinação de $2 \%$, não indicava eficiência na condução de águas de chuvas, sendo necessários novos drenos incorporados ao projeto de restauração.

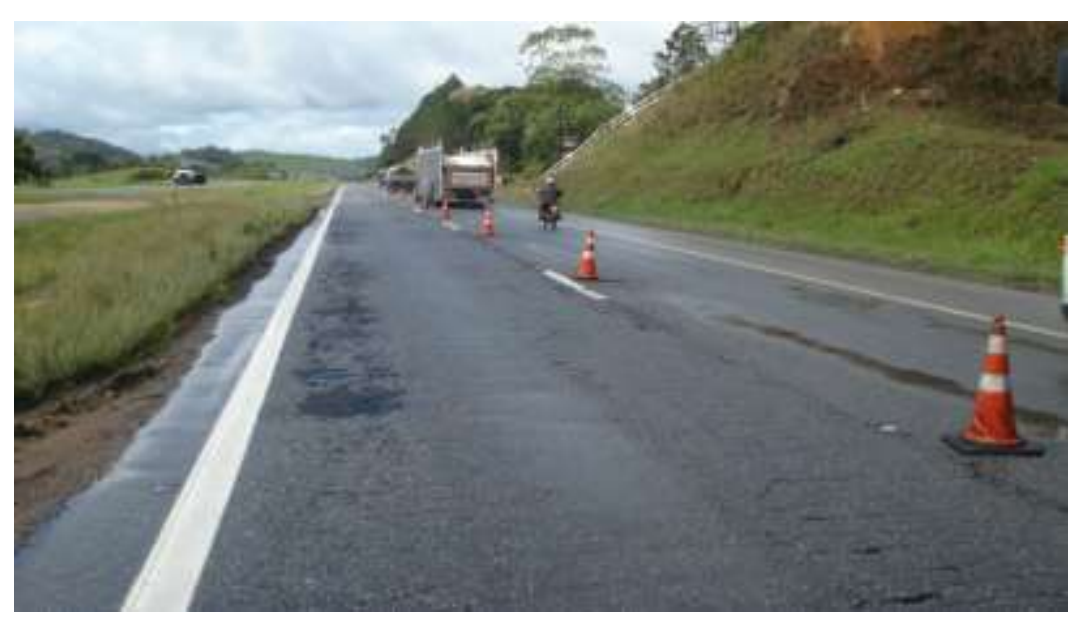

Figura 39 - Deformação permanente em trilha de roda no trecho experimental antes da restauração 
A investigação das condições do trecho experimental contemplou a abertura de valas que indicou a presença de trincamento restrito à camada de rolamento, sem comprometer camadas subjacentes. O trecho experimental também foi avaliado antes da intervenção por meio de medidas deflectométricas, que revelaram condição estrutural comprometida, com elevados níveis de deflexão (Figura 40); o trecho apresentado contempla todo os segmentos executados.

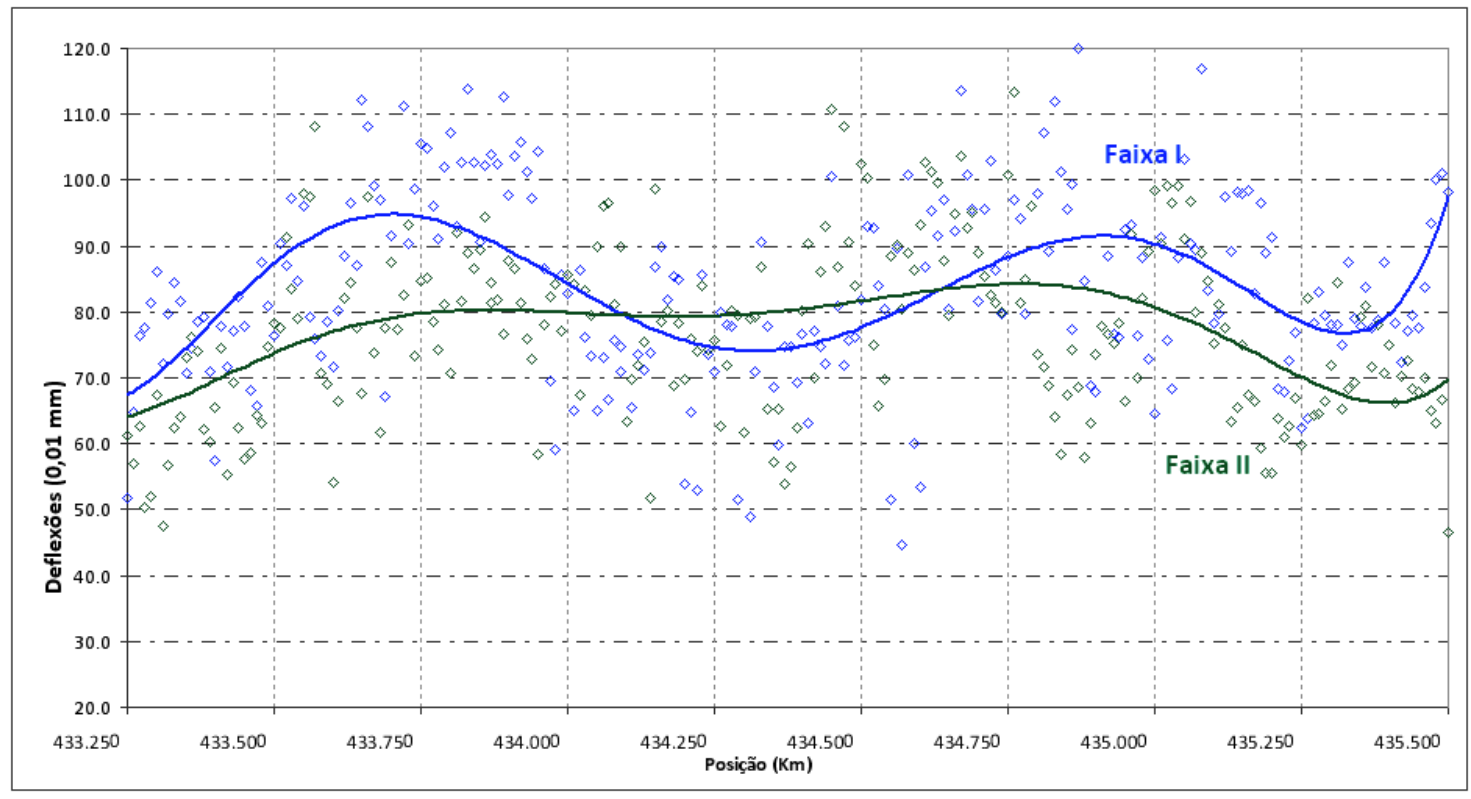

Figura 40 - Levantamento deflectométrico no trecho experimental, antes da intervenção

\subsubsection{Volume de Tráfego}

A rodovia Régis Bittencourt serve como principal acesso rodoviário entre as regiões Sul e Sudeste do Brasil, sendo importante rota para o fluxo de mercadorias, regularmente realizado por meio de caminhões. De acordo com a concessionária, o tráfego é composto por aproximadamente $60 \%$ de veículos comerciais, e estima-se que parte deles trafega com carga maior do que a carga máxima legal. Esses veículos trafegam com velocidade baixa, em torno de $50 \mathrm{~km} / \mathrm{h}$, acentuando danos, especialmente os relacionados à deformação permanente.

Dados de composição e fluxo de tráfego fornecidos pela concessionária foram utilizados para determinação do número de repetições de carga do eixo padrão $\mathrm{N}$ atuante para o período de um ano. Os veículos categorizados em acordo com a 
ANTT são contabilizados diariamente, nas praças de pedágio (Tabela 12). Os dados utilizados nesta pesquisa referem-se ao pedágio da Cidade de Registro, no quilômetro 426+600, sendo distante do trecho experimental em apenas sete quilômetros, sem acessos que possam diferenciar o tráfego entre o trecho experimental e o pedágio.

Tabela 12 - Porcentagem das categorias de veículos utilizadas na definição do volume de tráfego

Porcentagem de Veículos Comerciais por Categoria

\begin{tabular}{|c|c|l|c|}
\hline Categoria 2 & 2C & Caminhão leve, ônibus, caminhão-trator e furgão & $10,81(\%)$ \\
\hline Categoria 3 & 3C & Automóvel e caminhonete com semi-reboque & $0,21(\%)$ \\
\hline Categoria 4 & 3C & Caminhão, caminhão-trator, caminhão-trator com semi-reboque e ônibus & $33,85(\%)$ \\
\hline Categoria 5 & 2S2 & Automóvel e caminhonete com reboque & $0,02(\%)$ \\
\hline Categoria 6 & 2S2 & Caminhão com reboque e caminhão-trator com semi-reboque & $6,31(\%)$ \\
\hline Categoria 7 & 2S3 & Caminhão com reboque e caminhão-trator com semi-reboque & $27,47(\%)$ \\
\hline Categoria 8 & 3S3 & Caminhão com reboque e caminhão-trator com semi-reboque & $21,34(\%)$ \\
\hline Eixos Adicionais & - & Cargas Especiais & - \\
\hline & & & $\sum=100 \%$ \\
\hline
\end{tabular}

A partir da definição do número de veículos em cada categoria, e ainda combinação de carregamento (sem considerar veículos com sobrecarga), definiu-se para o período entre março/2009 e março/2010, um número $\mathrm{N}$ anual atuante de 1,6 x 107, revelando tráfego elevado (Tabela 13) segundo cálculo com fatores de carga da USACE, método considerado nos projetos de dimensionamento.

Tabela 13 - Fatores considerados e cálculo do Número N Número $\mathrm{N}$ atuante - período 03/2009 a 03/2010

\begin{tabular}{|c|c|c|c|c|c|}
\hline VDM,com,bid & dias/ano & Fcresc & FV & Fator Pista & Número N \\
\hline 10823 & 365 & 1,0005 & 8,093845 & 0,5 & $1,60 \mathrm{E}+07$ \\
\hline
\end{tabular}

\begin{tabular}{|ll|}
\hline \multicolumn{2}{|c|}{ Fator de crescimento } \\
\hline taxa de crescimento $=$ & $0,10 \%$ \\
\hline período de projeto $=$ & 1 anos \\
\hline fator de crescimento para 1 ano $=$ & 1,0005 \\
\hline
\end{tabular}

Este número de repetições de carga indica relativa coerência quando comparado ao $\mathrm{N}$ calculado no projeto de restauração da Rodovia, que considera taxa de 
crescimento de 3,0\% ao ano, gerando $\mathrm{N}$ de $8,7 \times 10^{7}$ (método de cálculo segundo a AASHTO) e de $2,2 \times 10^{8}$ (método de cálculo segundo a USACE), para o período de 8 anos (Tabela 14).

Os valores apresentados pela concessionária se basearam nos seguintes fatores: $70 \%$ de veículos comerciais com carregamento máximo legal, $20 \%$ de veículos sem carga (vazio) e 10\% dos veículos com excesso de carga, com base em contagens realizadas no ano de 2007 , nos pontos definidos como futuras praças de pedágio.

Tabela 14 - Número $\mathrm{N}$ de projeto

\begin{tabular}{|c|c|c|c|c|}
\hline \multirow{2}{*}{ ANO } & \multicolumn{2}{|c|}{$\mathrm{N}$ - AASHTO } & \multicolumn{2}{c|}{$\mathrm{N}$ - USACE } \\
\cline { 2 - 2 } & No Ano & \multirow{2}{*}{ Acumulado } & No Ano & \multirow{2}{*}{ Acumulado } \\
\cline { 2 - 2 } & $9,54 \mathrm{E}+06$ & & $2,40 \mathrm{E}+07$ & \\
\hline 2008 & $9,82 \mathrm{E}+06$ & $9,82 \mathrm{E}+06$ & $2,47 \mathrm{E}+07$ & $2,47 \mathrm{E}+07$ \\
\hline 2009 & $1,01 \mathrm{E}+07$ & $1,99 \mathrm{E}+07$ & $2,55 \mathrm{E}+07$ & $5,02 \mathrm{E}+07$ \\
\hline 2010 & $1,04 \mathrm{E}+07$ & $3,04 \mathrm{E}+07$ & $2,62 \mathrm{E}+07$ & $7,64 \mathrm{E}+07$ \\
\hline 2012 & $1,07 \mathrm{E}+07$ & $4,11 \mathrm{E}+07$ & $2,70 \mathrm{E}+07$ & $1,03 \mathrm{E}+08$ \\
\hline 2013 & $1,11 \mathrm{E}+07$ & $5,21 \mathrm{E}+07$ & $2,78 \mathrm{E}+07$ & $1,31 \mathrm{E}+08$ \\
\hline 2014 & $1,14 \mathrm{E}+07$ & $6,35 \mathrm{E}+07$ & $2,87 \mathrm{E}+07$ & $1,60 \mathrm{E}+08$ \\
\hline 2015 & $1,17 \mathrm{E}+07$ & $7,53 \mathrm{E}+07$ & $2,95 \mathrm{E}+07$ & $1,89 \mathrm{E}+08$ \\
\hline 2016 & $1,21 \mathrm{E}+07$ & $8,73 \mathrm{E}+07$ & $3,04 \mathrm{E}+07$ & $2,20 \mathrm{E}+08$ \\
\hline Número N de Projeto & AASHTO & $\mathbf{8 , 7 3 E + 0 7}$ & USACE & $\mathbf{2 , 2 0 E + 0 8}$ \\
\hline
\end{tabular}

O volume de tráfego é uma condição determinante no desempenho dos pavimentos. O número de solicitações a que o pavimento deve estar sujeito define o desenho da estrutura, pois a repetição de cargas é responsável pela maior parte dos defeitos que conduzem à ruína dos pavimentos.

\subsubsection{Fatores Climáticos e Ambientais}

Pavimentos são estruturas destinadas a resistir aos esforços do tráfego e variação climática, proporcionando dirigibilidade e segurança aos usuários sob quaisquer destas variações. Da mesma forma que o tráfego, as condições climáticas têm influência direta no desempenho de pavimentos desde sua concepção. O DNER PRO 11/1979 indica que as medidas de deflexão devem ser feitas imediatamente após a estação chuvosa, quando o subleito apresenta a máxima umidade. 
O Brasil apresenta clima tropical, com temperaturas elevadas na maior parte do ano, e regime de chuvas intenso; entretanto, suas dimensões continentais impõem variações que devem ser especificadas por região quando consideradas nos projetos de pavimentos. Segundo a classificação climática de Köppen, a região Sudeste do Brasil apresenta predominância de clima temperado úmido com verões quentes (Cfa). Contudo a região litorânea do Estado de São Paulo, onde se encontra a cidade de Registro, com altitude de $25 \mathrm{~m}$ em relação ao nível do mar, diferencia-se nesta classificação correspondendo à classe $A f$, clima tropical úmido, ou clima equatorial, caracterizado principalmente pela forte precipitação anual (EMBRAPA, 2010).

O monitoramento das condições de precipitação e de temperatura máxima e mínima, na região que inclui o trecho experimental está disposto na Figura 41, apresentando a coleta de dados no período da pesquisa.

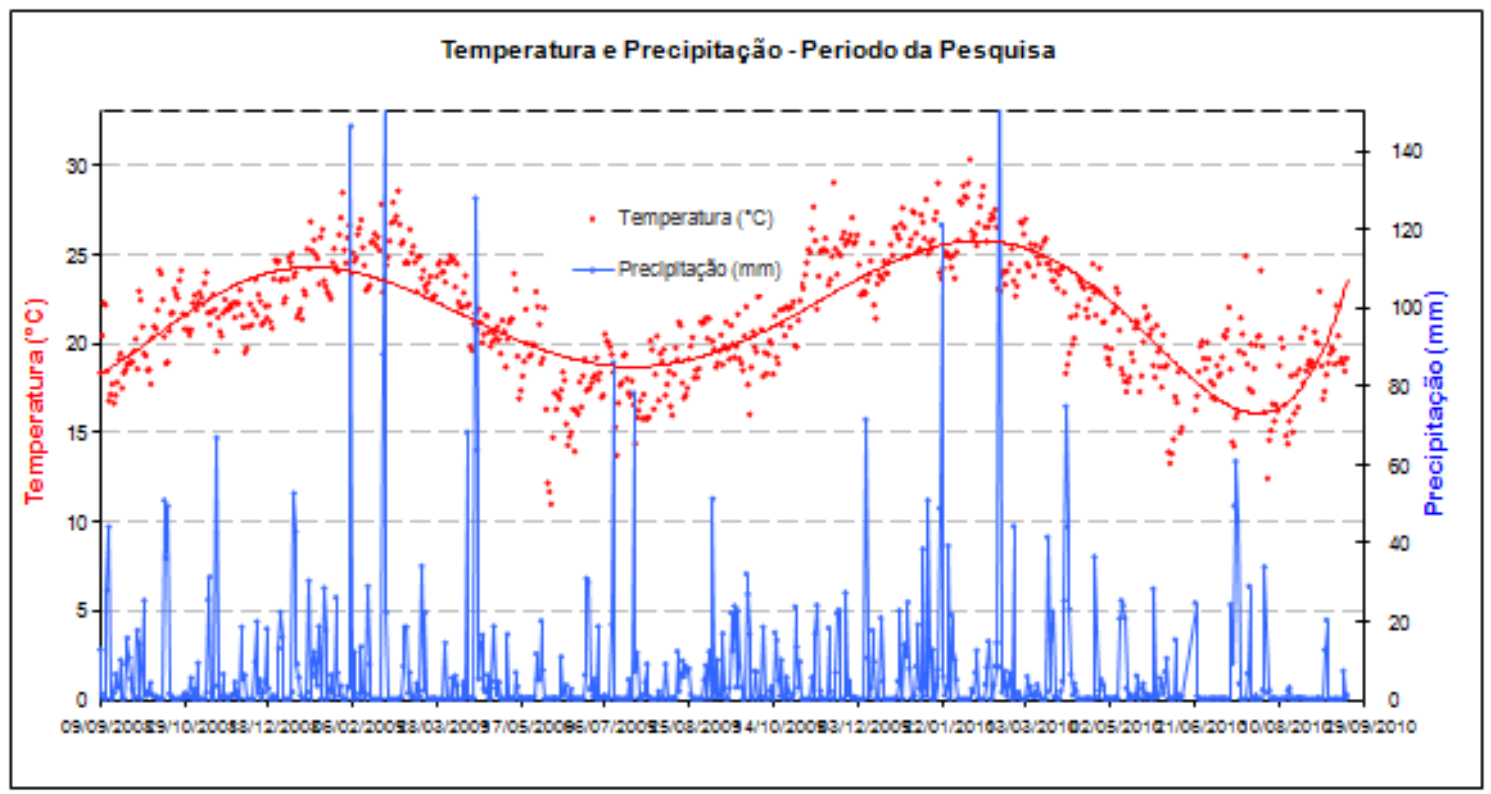

Figura 41 - Resumo de dados de precipitação e temperatura na região do trecho experimental no período da pesquisa. Fonte: Inmet, 2010

Os altos índices pluviométricos indicam que a incidência de chuvas tem potencial para saturação de subleito, além de exigir drenagem adequada. As misturas recicladas a frio têm elevado volume de vazios, e não devem trabalhar expostas sob condições de chuvas intensas. O projeto deve prever camada delgada de rolamento para proteção e impermeabilização da camada reciclada. 


\subsection{Solução de Restauração Indicada no Projeto}

O conjunto de informações obtidas pela avaliação do pavimento foi: volume de tráfego elevado, $\mathrm{N}=8,7 \times 10^{7}$ (AASHTO) para período de 8 anos, temperatura média anual $=22{ }^{\circ} \mathrm{C}$ e média pluviométrica $=74 \mathrm{~mm} /$ mês, revestimento asfáltico comprometido, trincamento FC $3 \mathrm{em} 100 \%$ da área do trecho experimental, deformação permanente em $12 \%$ da extensão, drenagem deficiente e camadas subjacentes aparentemente íntegras. Estas características são consideradas representativas da rodovia, permitindo que os resultados sejam extrapolados para outros trechos e norteando a escolha do processo adequado de reabilitação, a fim de prolongar a vida útil do pavimento quando este atinge condições mínimas admissíveis.

A reciclagem a frio in situ foi indicada para a restauração do trecho experimental, baseado em uma série de fatores, sendo os principais: (i) corrige os principais tipos de defeitos funcionais verificados (trincamento e deformação permanente), (ii) tem processo de construção eficiente, diminuindo período de fechamento da via, (iii) mistura em temperatura ambiente, que permite rápida abertura ao tráfego, (iv) dá destinação a todo o material extraído da pista, sem exigir pontos de instalação provisórios ou bota-foras de apoio operacional.

O trecho experimental submetido ao processo de reciclagem a frio in situ, foi subdividido em nove segmentos homogêneos, cada um com 250 metros, a fim de avaliar apropriadamente os impactos de variações na reciclagem. Para tanto foram propostas:

- Variações nas espessuras da camada reciclada $(8 \mathrm{~cm}, 11 \mathrm{~cm}$ e $15 \mathrm{~cm})$;

- Diferentes tipos de aditivo na mistura reciclada (cal e cimento);

- Variação no tipo de material da camada de rolamento (CBUQ e Microrrevestimento).

A partir destas combinações, o trecho experimental ficou definido com as configurações esquematicamente distribuídas na Figura 42. 


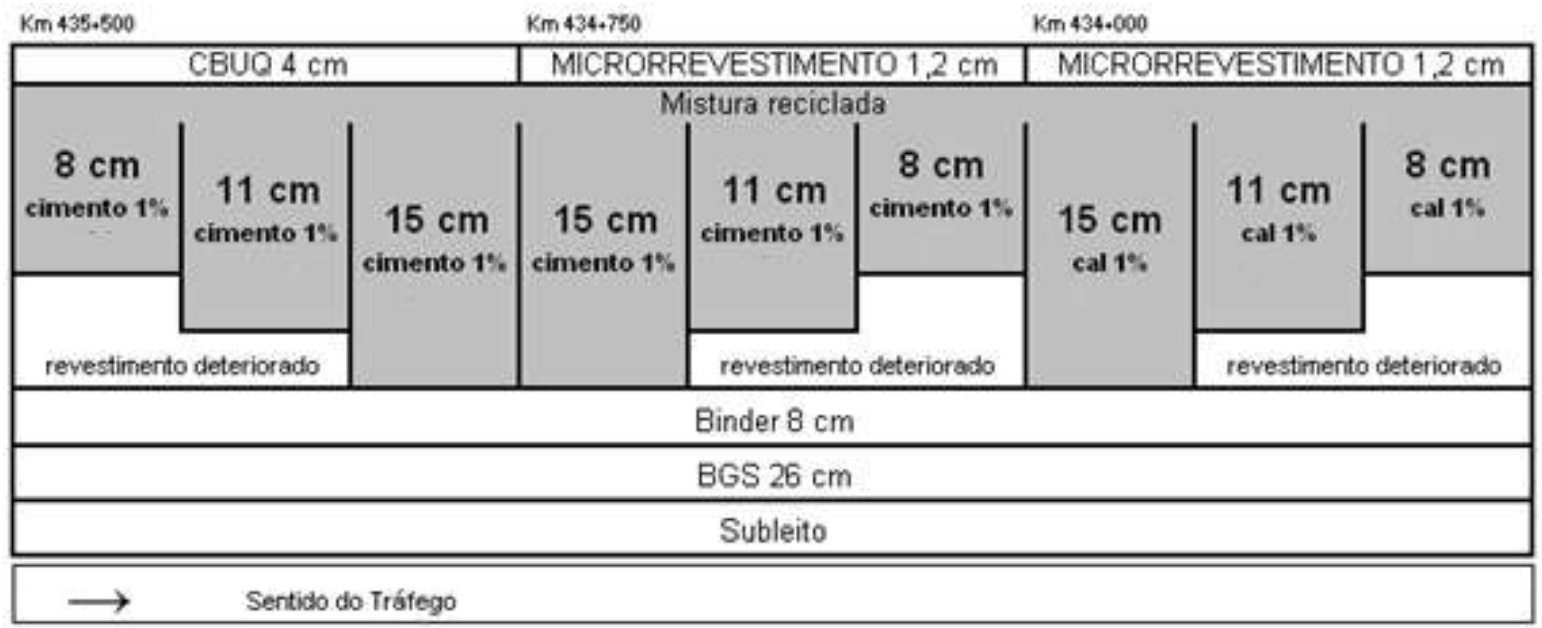

Figura 42 - Configuração esquemática do trecho experimental

\subsection{Divisão dos Segmentos}

O trecho experimental construído na Rodovia Régis Bittencourt - BR 116, possui extensão total de 2250 metros, com duas faixas de tráfego.

Os segmentos em que foi aplicada mistura reciclada com adição de cal, apresentaram diversos problemas, levando a formação de panelas e desagregação, conforme se verifica na Figura 43. Os problemas começaram a se revelar após 3 meses da execução da camada de rolamento, exigindo constantes reparos, além da execução adicional de drenos longitudinais e transversais. Os problemas não foram atribuídos à adição de cal, mas a uma possível deficiência de drenagem destes segmentos que se dispõem em curva.

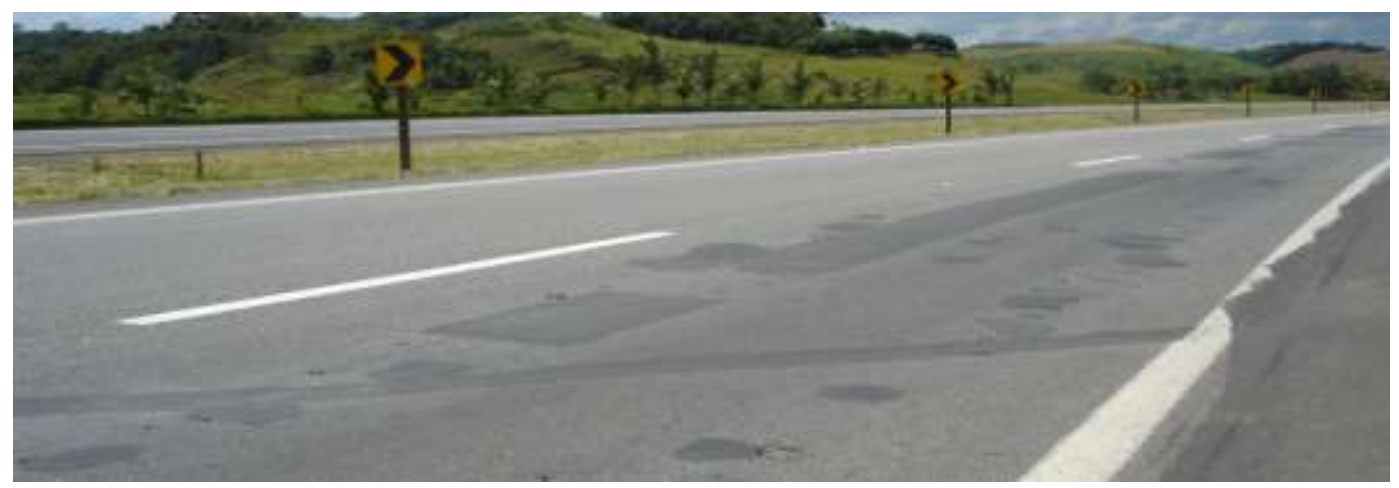

Figura 43 - Segmento reciclado com adição de cal - diversas intervenções após 3 meses da execução da camada de revestimento em microrrevestimento 
As medidas de deflexão realizadas antes da intervenção também apontaram valores mais altos para os segmentos problemáticos, indicando a possibilidade de problemas específicos nesta área do trecho experimental. As deflexões anteriores à restauração, dos segmentos reciclados com cal, alcançavam valores próximos de $100 \times 0,01 \mathrm{~mm}$, consideravelmente mais altas do que a média deflectométrica de 77 x $0,01 \mathrm{~mm}$ dos demais segmentos. Em virtude dos problemas expostos, os três segmentos foram excluídos da avaliação desta pesquisa. A Figura 44 mostra esquematicamente a disposição dos segmentos mantidos em avaliação nesta pesquisa.

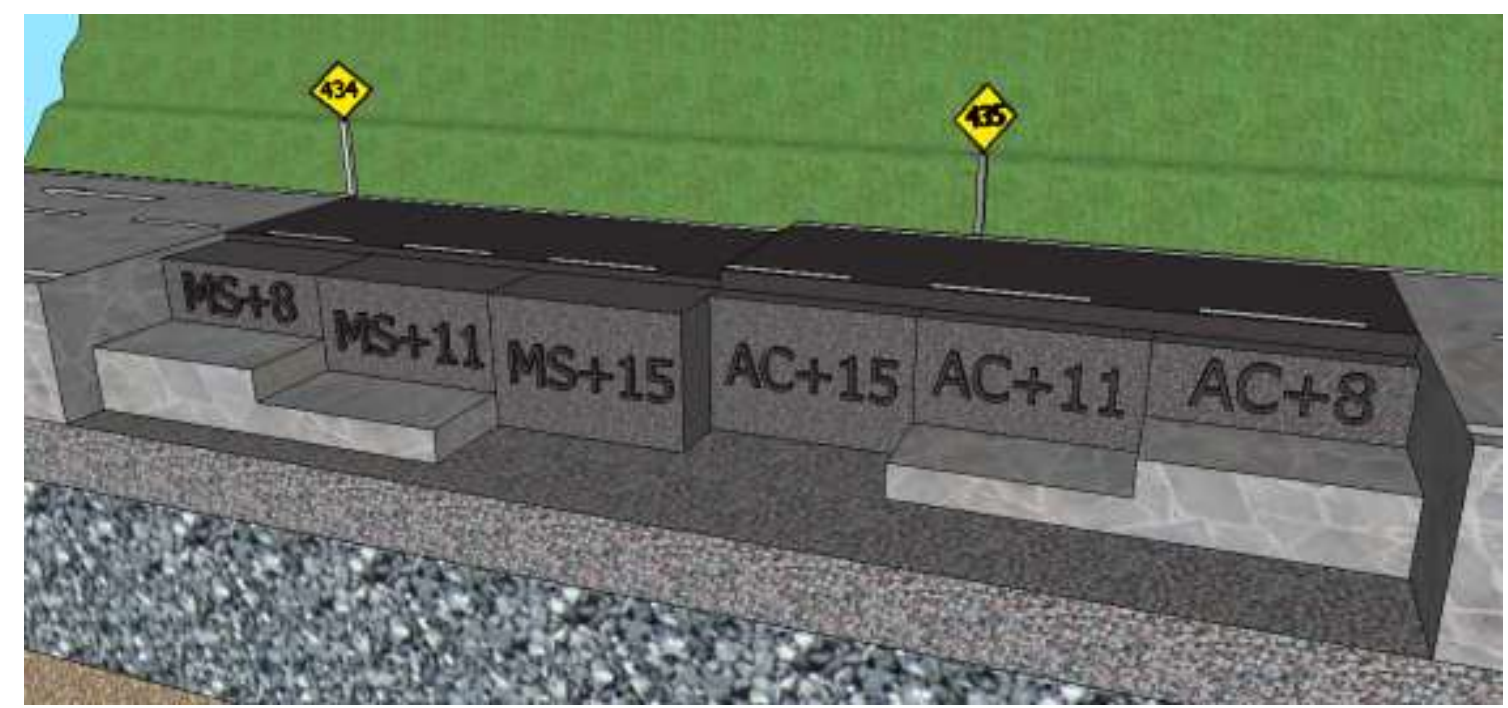

Figura 44 - Representação da estrutura do pavimento no trecho experimental após restauração

- Segmento $A C+15$ - Reciclagem com cimento $15 \mathrm{~cm}+\mathrm{CBUQ} 4 \mathrm{~cm}$

- Segmento AC+11 - Reciclagem com cimento $11 \mathrm{~cm}+\mathrm{CBUQ} 4 \mathrm{~cm}$

- Segmento AC+8 - Reciclagem com cimento $8 \mathrm{~cm}+\mathrm{CBUQ} 4 \mathrm{~cm}$

- Segmento MS+15 - Reciclagem com cimento $15 \mathrm{~cm}$ + Microrrevestimento 1,2 $\mathrm{cm}$

- Segmento MS+11 - Reciclagem com cimento $11 \mathrm{~cm}$ + Microrrevestimento 1,2 $\mathrm{cm}$

- Segmento MS+8 - Reciclagem com cimento $8 \mathrm{~cm}+$ Microrrevestimento 1,2 $\mathrm{cm}$ 
As variações propostas nas espessuras de reciclagem foram determinadas primordialmente em função da espessura da camada de revestimento envelhecido existente de $15 \mathrm{~cm}$. A primeira opção contemplou a reciclagem de toda a espessura da camada. A segunda opção, de $11 \mathrm{~cm}$, objetivou reciclar $70 \%$ da espessura total, isso porque pesquisas internacionais indicam que para mitigar a reflexão do trincamento, é necessário restaurar no mínimo essa porcentagem (ARRA, 2001). A camada reciclada inibe a reflexão de trincas, dado o elevado volume de vazios da mistura. A espessura final de $8 \mathrm{~cm}$ visa testar a eficiência da reciclagem quando executada na menor espessura possível do equipamento, além disso, é uma espessura considerada adequada para fins comparativos com as demais espessuras.

O uso de cimento como aditivo na mistura reciclada, conforme mencionado anteriormente, tem por objetivo principal aumentar a resistência inicial da mistura, tendo em vista que a utilização de emulsão não assegura a coesão inicial necessária, condição associada às características de ruptura e cura próprias. As misturas receberam aditivo sempre em teor próximo de $1 \%$. A falta de precisão deve-se a uma deficiência no equipamento utilizado na execução, que não possui dispositivo dosador de aditivo.

A mistura reciclada a frio tem elevado volume de vazios, entretanto é sensível à presença de água, e não deve ser utilizada como camada drenante, devendo receber sempre uma camada selante, que impeça o acesso direto da água. A espessura da camada de rolamento, no entanto, deve ser avaliada estruturalmente. A colocação de capa selante sobre a camada reciclada, apesar de fundamental para o correto desempenho desta, não oferece incremento estrutural, de forma que condições de tráfego mais severas implicam diretamente na aplicação de camadas mais espessas de material mais nobre, capazes de prover resistência estrutural ao conjunto.

Assim, esta pesquisa objetivou comparar o desempenho de pavimentos reciclados com capa selante (microrrevestimento asfáltico) e capa de concreto asfáltico. Temse indicado misturas recicladas cobertas por capas selantes para vias com baixo 
volume de tráfego, e para vias de maior importância, exige-se aumento na espessura da camada de rolamento, com o aumento do volume de tráfego.

Embora o tráfego seja elevado na Rodovia, onde se localiza o trecho experimental e desestimule o uso de camada selante, esta pesquisa objetivou avaliar os impactos do tráfego em estruturas com capa selante, por ser uma medida reconhecidamente mais econômica e que pode, eventualmente, integrar processos de gerência de pavimentos, com restauração em etapas.

A espessura da camada de concreto asfáltico é considerada incremento que contribui na estrutura de modo a resistir aos esforços do tráfego elevado. A escolha pela espessura relativamente delgada desta camada, de $4 \mathrm{~cm}$, objetiva verificar valores mínimos de concreto asfáltico que o diferencie de capa selante e que apresentem desempenho estrutural superior. A colocação de camada de concreto asfáltico mais espessa pode ser avaliada, contudo a espessura delgada serve de referência em termos de resistência, oferecendo rapidamente resultados sobre o comportamento da estrutura.

Deve-se observar que a fresagem de espessuras menores do que a maior espessura da camada, no caso $15 \mathrm{~cm}$, permite que permaneça parte da camada antiga, que pode apresentar condições diferenciadas de integridade ou degradação com a profundidade. Por questões operacionais não foi possível fazer a verificação das características estruturais desta camada remanescente, tendo apenas observado relativa homogeneidade superficial, após a fresagem (Figura 45). 


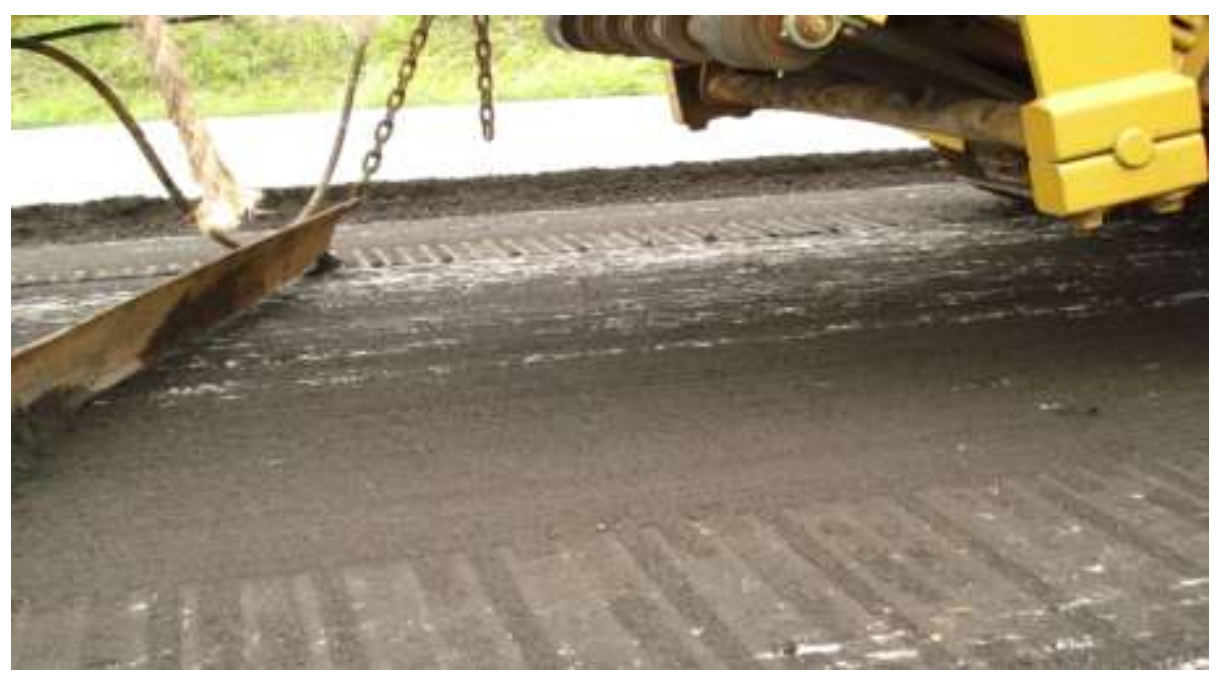

Figura 45 - Aparência superficial homogênea do pavimento após a fresagem

Para a definição dos projetos, foram considerados valores de deflexão e de irregularidade longitudinal, sem considerações específicas acerca das condições de subleito.

\subsection{Processo de Execução}

A reciclagem a frio in situ mostrou-se um processo rápido de restauração. Foram definidos os teores de projeto (teor de emulsão de 3,5\%, teor de umidade de $3 \%$ e teor de aditivo de 1\%), a partir da dosagem Marshall, realizada pelo executor. $\mathrm{A}$ dosagem foi discutida e analisada nesta pesquisa - capítulo 3. Para ambas as faixas de rolamento, faixa I de veículos leves e faixa II de veículos pesados, o projeto considerado para a reciclagem foi o mesmo, tendo como condição mais crítica a faixa de veículos lentos, ou seja, faixa II.

O equipamento utilizado na execução do trecho experimental, denominado trem de reciclagem (Figura 46), agrupa todas as operações necessárias à restauração em uma seqüência invariável. Neste sistema, o equipamento fresador tem força para conduzir as demais partes integrantes e o trem de reciclagem tem capacidade para executar uma faixa de 3,6 metros numa única etapa. Desta forma, a execução principiou pela faixa II, ficando a faixa I liberada para o tráfego. 


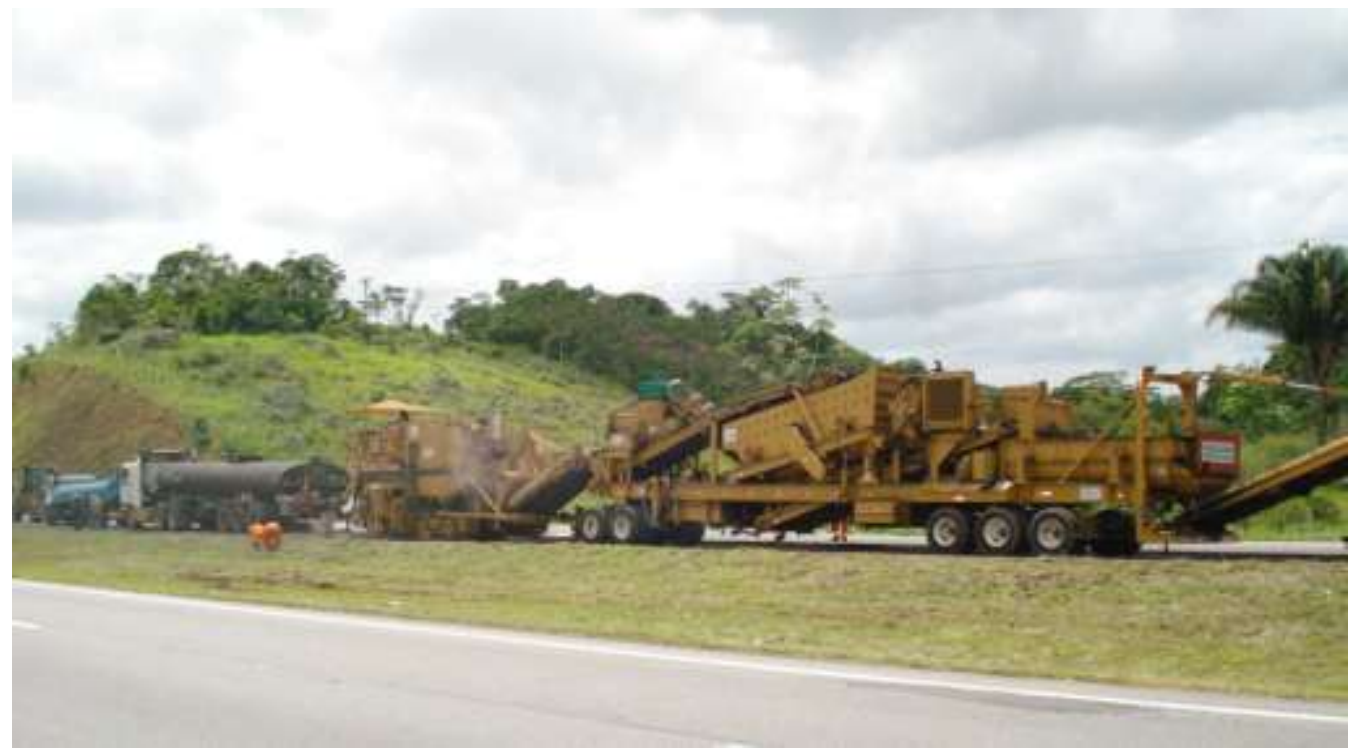

Figura 46 - Trem de reciclagem utilizado na restauração do trecho experimental

A Figura 47 ilustra a seqüência executiva das etapas do processo de reciclagem utilizado no trecho experimental. As etapas serão descritas detalhadamente a seguir. 
Distribuição de agregados virgens (caso previsto no projeto)

Distribuição de aditivo (cal ou cimento)

Fresagem da camada deteriorada com adição de água

Seleção granulométrica do material fresado

Rebritagem de materiais rejeitados na seleção granulométrica

Pintura de ligação com emulsão (espargidores)

Condução dos agregados fresados+aditivo+água para a misturadora

Adição de emulsão

Misturação final do material

Distribuição da mistura no pavimento

Compactação com rolo chapa

Compactação com rolo de pneu

Salgamento da Pista

Abertura ao Tráfego

Figura 47 - Sequência executiva da reciclagem a frio in situ 
A execução do trecho experimental avaliado nesta pesquisa não recebeu adição de material virgem, sendo a mistura composta exclusivamente por agregados fresados. Entretanto, quando previsto em projeto, o processo é iniciado com a distribuição de agregados virgens.

A incorporação do cimento como aditivo, faz-se por meio de distribuição na pista a ser fresada, tais quais os agregados virgens, de forma que quando a fresagem se inicia, os materiais são "aspirados" juntamente com o pavimento que está sendo desbastado. A distribuição dos aditivos ocorre de forma improvisada sem controle exato dos teores lançados em pista. Para esta execução os sacos de $50 \mathrm{~kg}$ do aditivo foram distribuídos a cada 10 metros, sem ponderações precisas acerca das variações de espessura (que aumenta ou diminui o consumo), tendo um simples controle visual (Figura 48), fator que tem diversas implicações, que serão discutidas no capítulo 5.

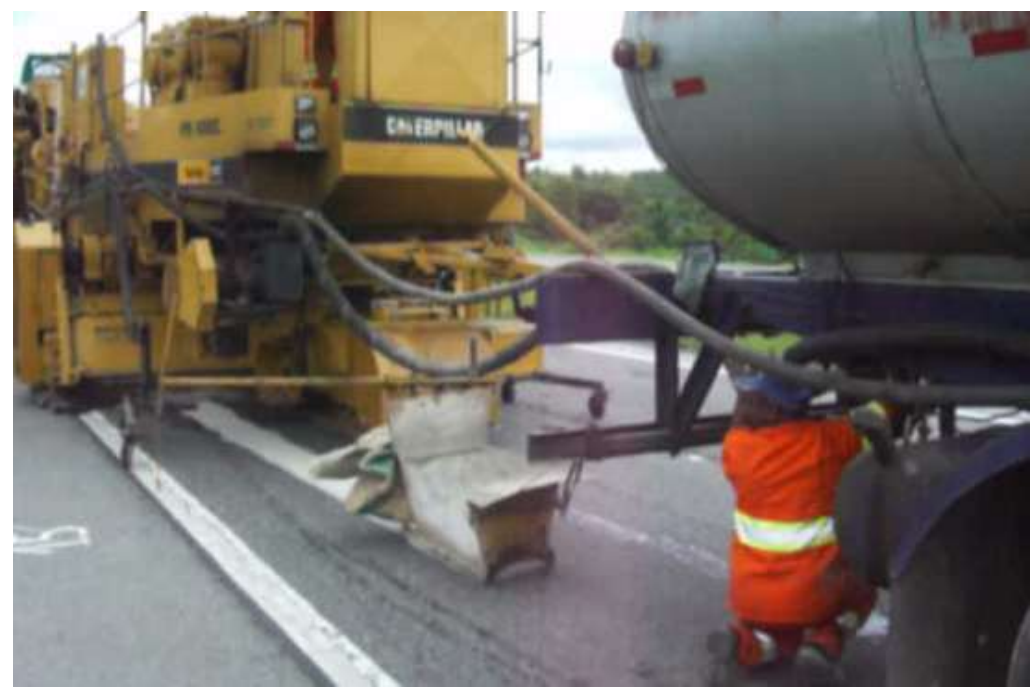

Figura 48 - Distribuição de aditivo antes da fresagem

O cilindro fresador com largura de 3,6 metros, composto por bits ou dentes de desbaste, inicia processo de rotação avançando em velocidade definida, fraturando o pavimento deteriorado e reduzindo o material deteriorado a pequenas dimensões (Figura 49). A velocidade de avanço adotada neste projeto foi de $4 \mathrm{~km} / \mathrm{h}$ e está associada às dimensões de agregado que se pretendia obter, às características da camada fresada e ainda às características do equipamento. Bonfim (2007) ressalta que maiores velocidades de avanço produzem agregados de maiores dimensões e 
diminuem a produção de finos, o que pode reduzir a coesão nas misturas recicladas a frio.

No processo de fresagem, é adicionado o teor de umidade necessário na produção da mistura reciclada. A adição de água nesta etapa tem duas funções primordiais: resfriar o cilindro fresador e mitigar a produção de pó oriunda da fresagem.

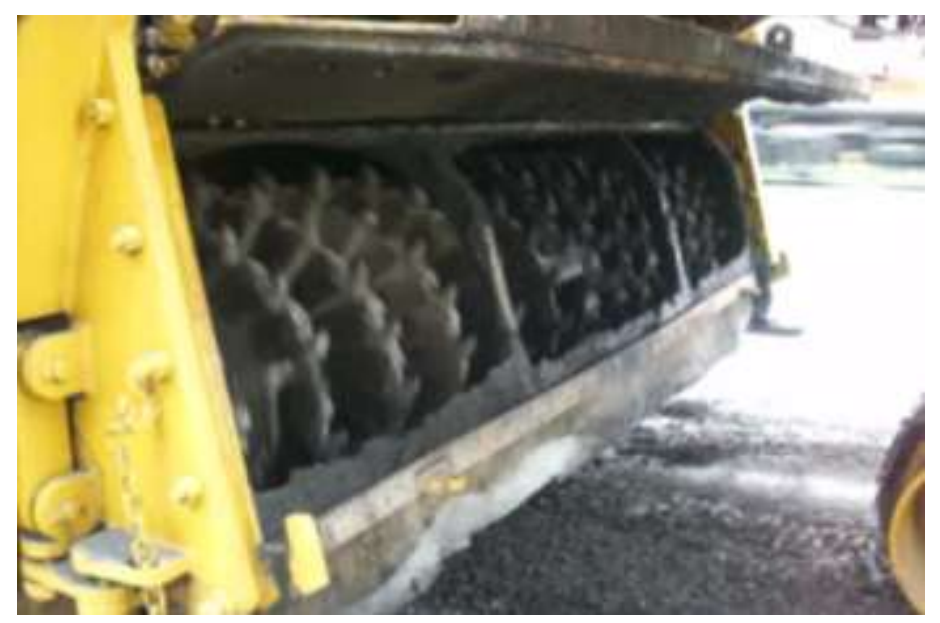

Figura 49 - Cilindro fresador com 3,6 metros de largura

O trecho de 1 metro junto ao canteiro central foi reciclado juntamente com a faixa I, tendo sido fresado com auxílio de um equipamento Bobcat. Os agregados provenientes desta fresagem foram espalhados na pista e incorporados à reciclagem (Figura 50). Análises granulométricas posteriores constataram que não houve alteração significativa por conta desta incorporação.

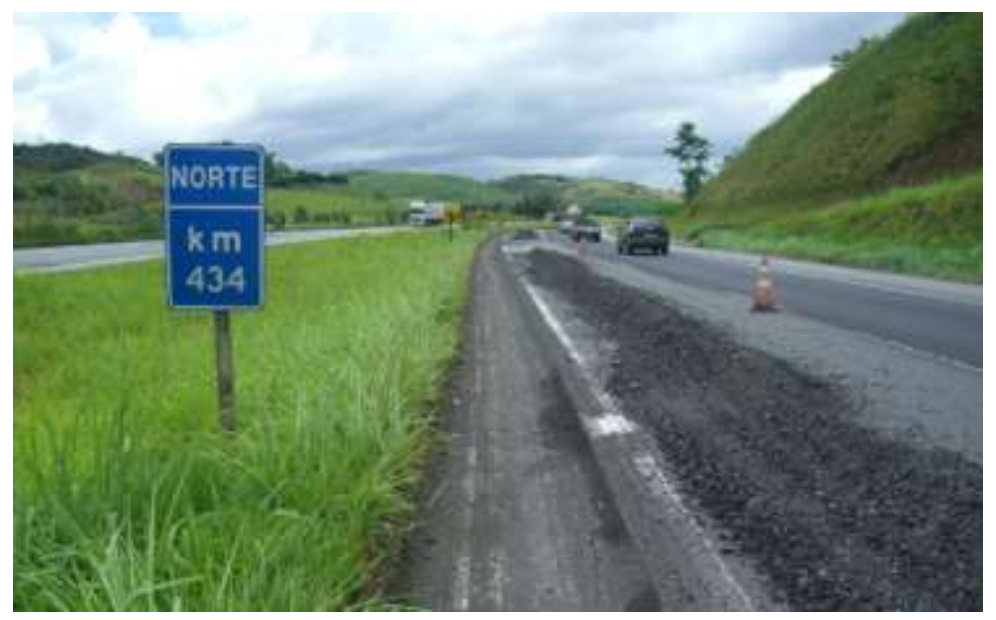

Figura 50 - Faixa junto ao canteiro central, com fresagem previa e execução concomitante com faixa I de rolamento 
O equipamento fresador possui sensores laterais de nivelamento e de espessura de fresagem, sendo possível controlar com relativa precisão, as espessuras de corte, além de garantir nivelamento com as faixas adjacentes (Figura 51). A transição longitudinal entre estacas com espessuras diferentes cobre uma extensão de aproximadamente 20 metros, ocasiões que requerem melhor domínio das estacas.

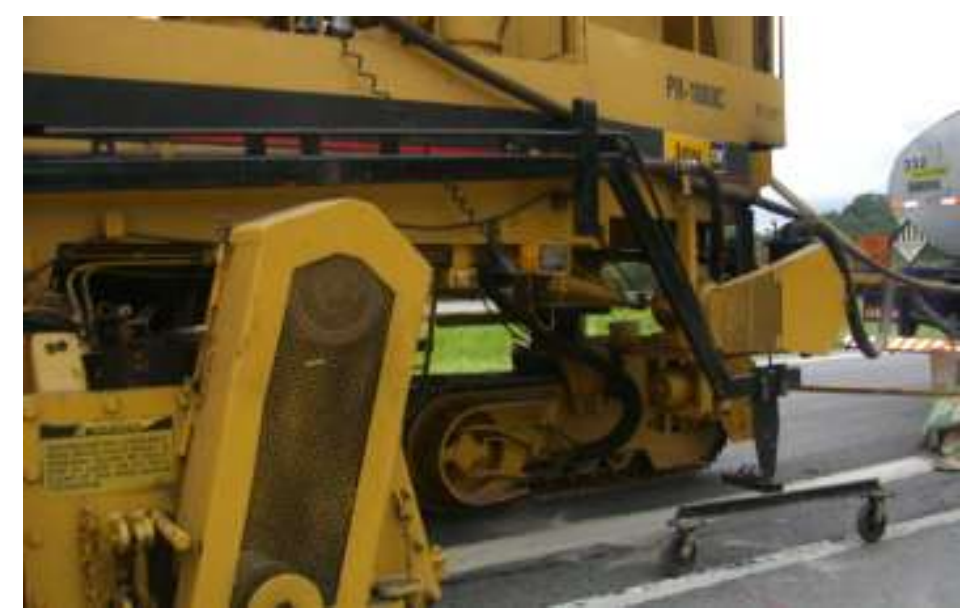

Figura 51 - Sensores laterais de nivelamento

Um rodo arrasta e espalha qualquer material que eventualmente caia da esteira de transporte após a fresagem, evitando assim a presença de material agregado sem ser misturado, que fica solto e quando em elevada proporção pode impedir a correta ligação entre a camada reciclada e a superfície subjacente (Figura 52).

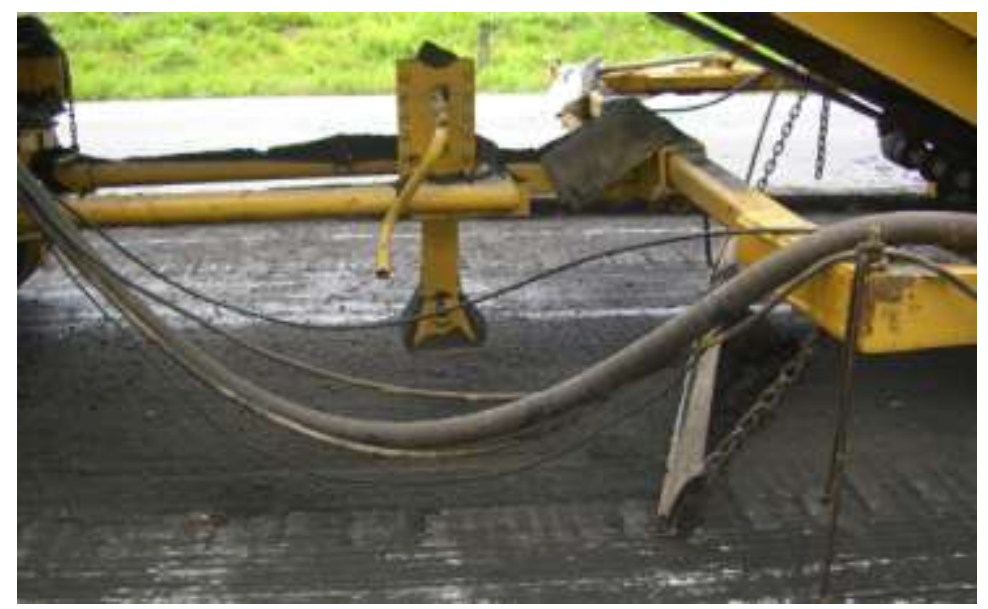

Figura 52 - Rodo para arraste e distribuição de agregados soltos

O agregado fresado é transportado por esteiras até uma estação de seleção granulométrica que limita o diâmetro nominal máximo em $31 \mathrm{~mm}$ (Figura 53). Para 
maior preservação desta peneira, a estação conta com uma peneira de abertura 50 $\mathrm{mm}$ que limita materiais em dimensões inapropriadas que possam congestionar a peneira de abertura $31 \mathrm{~mm}$. O equipamento não possui dispositivos que permitam o controle das demais frações granulométricas inferiores.

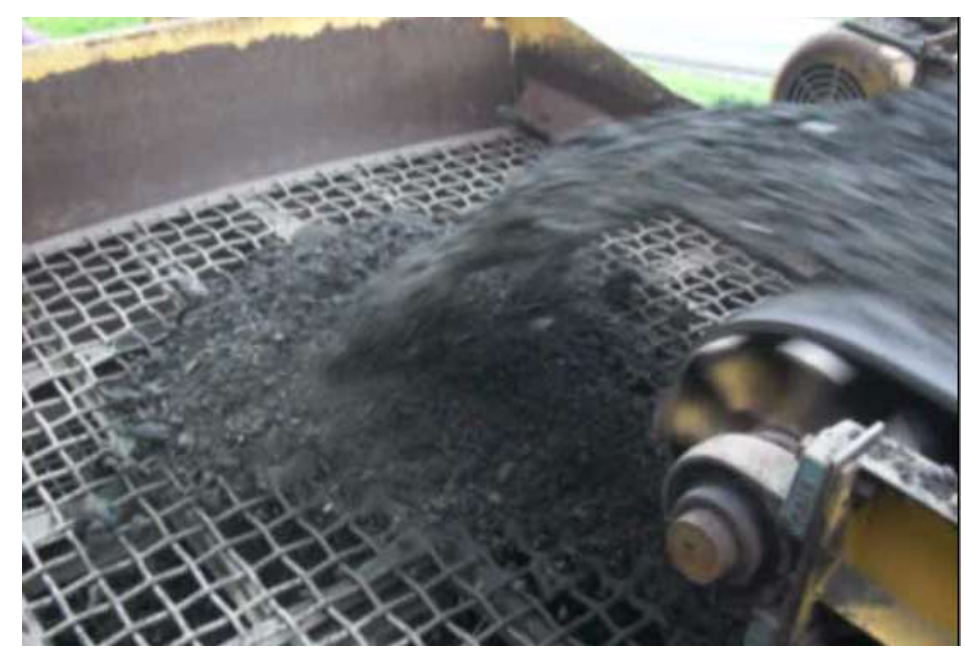

Figura 53 - Seleção granulométrica de agregados

O material rejeitado na seleção de diâmetro nominal máximo passa por um ciclo de rebritagem, de tal forma que nenhum material é descartado (Figura 54). Observações práticas indicam que trechos que sofreram maior número de intervenções tendem a apresentar maiores porcentagens de material rejeitado que volta para o britador. Esta constatação pode estar associada ao fato de que intervenções contêm materiais mais coesos que exigem maior energia para fraturar.

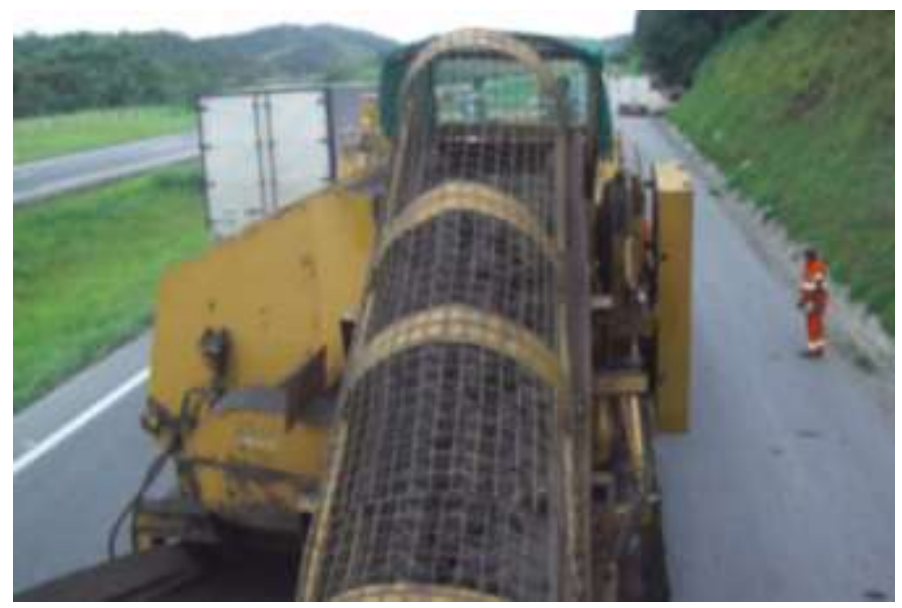

Figura 54 - Material rejeitado conduzido à rebritagem 
Após a seleção, a mistura de agregados fresados, aditivos incorporados e teor de água, é conduzida ao recipiente de misturação, onde é adicionado o teor de emulsão (Figura 55). O equipamento é dotado de medidor de vazão para identificar exatamente o teor lançado na misturadora (controle instalado imediatamente antes da emulsão ser lançada). Existe um primeiro controle quando a emulsão chega do tanque de emulsão no trem de reciclagem.

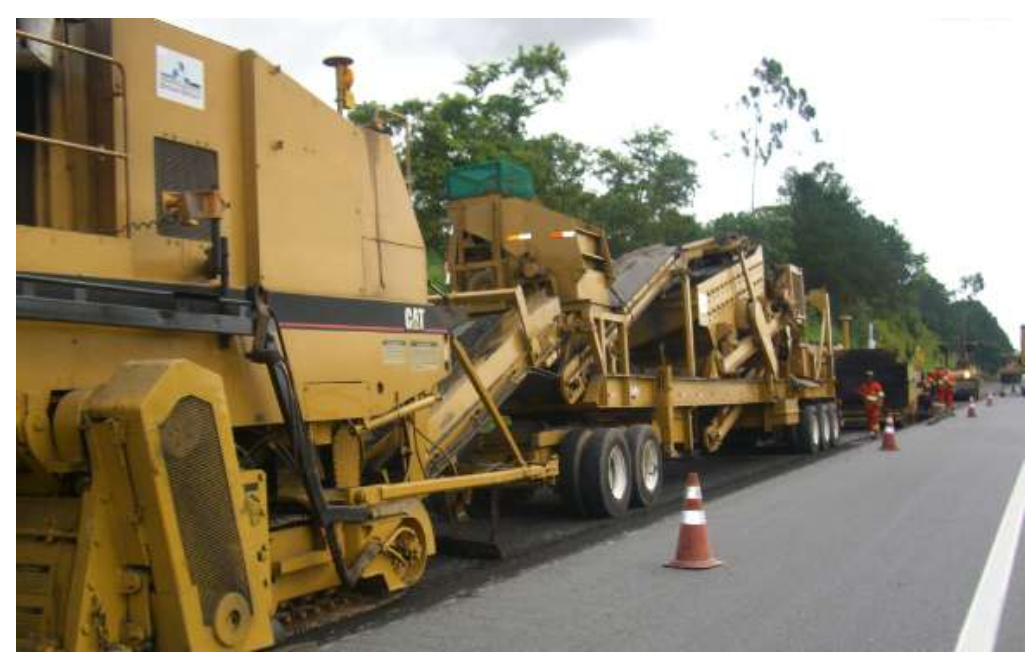

Figura 55 - Adição de emulsão no tanque de misturação final

Durante a etapa de misturação do material, um dispositivo instalado abaixo da misturadora com espargidores, realiza a pintura de ligação entre as camadas, distribuindo a mesma emulsão utilizada na mistura (Figura 56).

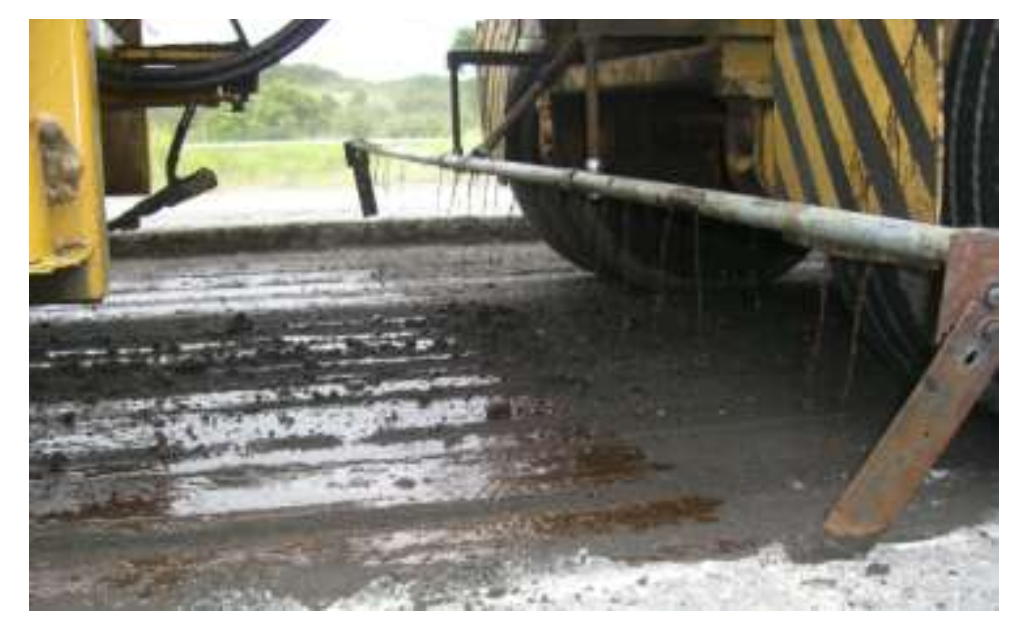

Figura 56 - Espargidores para realização de pintura de ligação 
A mistura reciclada pronta é conduzida por meio de esteira transportadora até a unidade distribuidora. Esta unidade não está vinculada fisicamente ao trem de reciclagem, permitindo manobras operacionais. A vibroacabadora distribui o material com auxílio de rosca sem fim, assegurando a homogeneidade da mistura na largura total da faixa (Figura 57).

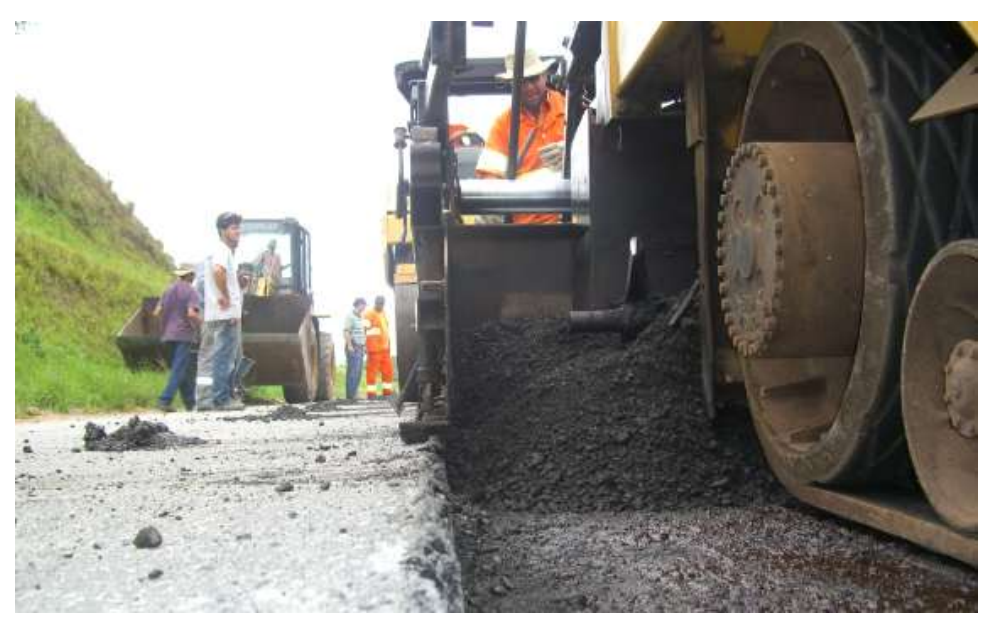

Figura 57 - Vibroacabadora com distribuição por rosca sem fim

Apesar de não estar conectada ao trem de reciclagem, a acabadora mantém a velocidade a fim de não perder o abastecimento pela esteira. Se houver afastamento entre o trem e a acabadora, o material reciclado cai direto na pista sem ser distribuído pela acabadora. Quando a quantidade de material é muito grande, o processo precisa ser interrompido desde o início do ciclo, para a correção do fluxo (Figura 58), e o material excedente não é depositado na acabadora.

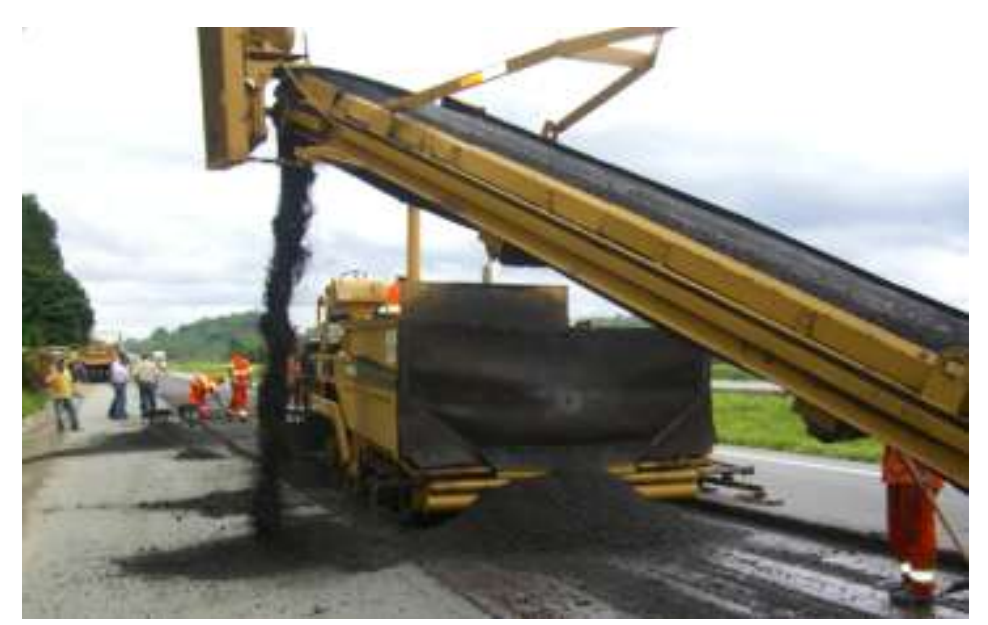

Figura 58 - Acabadora desconectada do trem de reciclagem 
Após a distribuição, inicia-se a compactação. Primeiro o rolo chapa passa duas vezes (Figura 59), depois o primeiro rolo de pneu com 90 libras e o segundo rolo de pneu com 110 libras, totalizando cerca de 5 a 6 passadas. Finaliza com rolo chapa e antes de abrir ao tráfego passa mais uma vez com o rolo de pneu mais pesado.

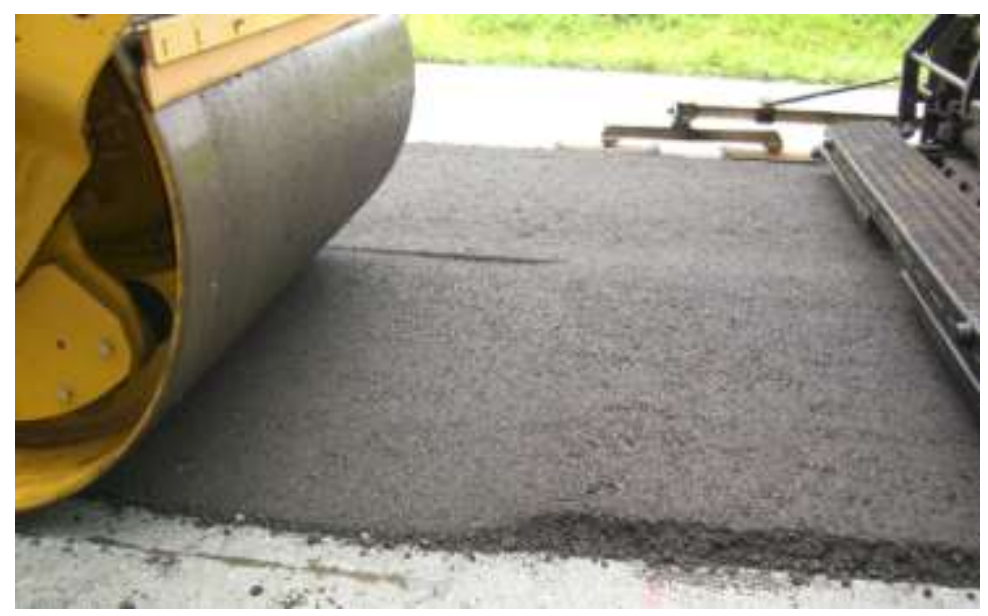

Figura 59 - Compactação com rolo chapa

A abertura ao tráfego é precedida pelo "salgamento" da pista. A distribuição de areia denominada "salgamento" impede que a emulsão possa aderir nos pneus, impedindo assim o arrancamento de agregados (Figura 60). Cada faixa de tráfego foi executada em um dia completo de atividades, com imediata abertura ao tráfego.

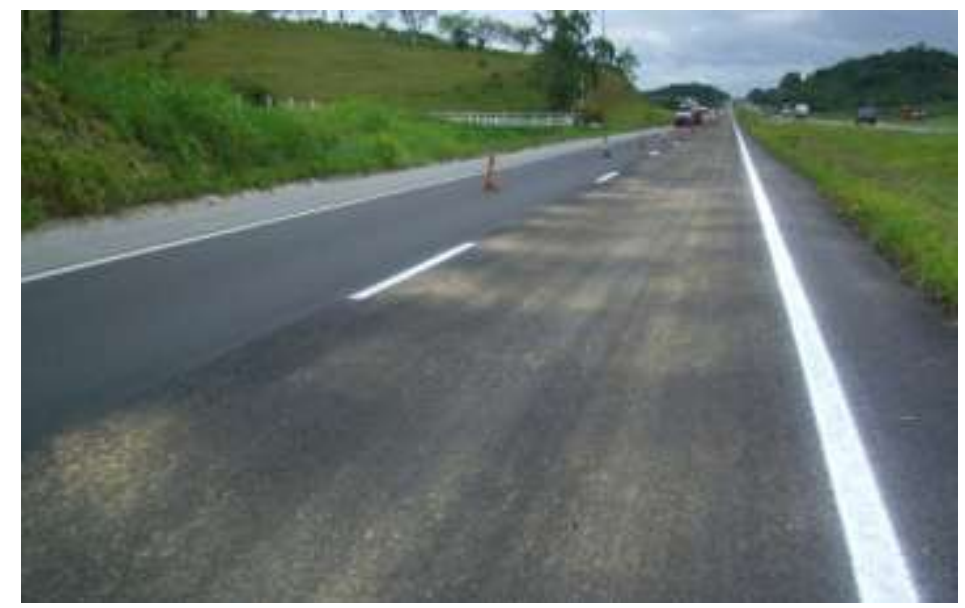

Figura 60 - Salgamento do pavimento reciclado antes da abertura ao tráfego

A camada reciclada permaneceu exposta ao tráfego por um período de três meses, entre novembro de 2008 e fevereiro de 2009, compreendendo um período de chuvas intensas. De acordo com pesquisas internacionais, são necessários no mínimo 14 
dias de cura antes da colocação da capa de rolamento sobre a mistura reciclada, mas em virtude dos altos índices pluviométricos, optou-se por estender o período.

A execução das camadas de $C B \cup Q$ e microrrevestimento asfáltico ocorreu em datas próximas. As características das misturas utilizadas foram descritas no capitulo 3. 


\section{MONITORAMENTO DE DESEMPENHO DO TRECHO EXPERIMENTAL}

Atualmente, processos de reabilitação são fundamentados em avaliações das condições de superfície, estrutural, funcional, de segurança e econômicas, buscando prever o desempenho futuro em função da estratégia adotada. Os processos envolvidos na ruína dos pavimentos constituem uma complexa interação entre as características da estrutura, do tráfego e do clima.

Os experimentos realizados na AASHO Road Test revelaram fatores básicos de controle e avaliação dos pavimentos tendo resultados significativos, aplicados até os dias atuais, com relação à de equivalência de cargas, efeito de espessura e resistência das camadas e, conceito de desempenho e serventia (Hallin et al., 2007).

O ciclo de vida dos pavimentos está diretamente associado à deterioração destes, sendo fundamental a implantação de planos de manutenção periódica que restabeleçam condições de trafegabilidade com conforto e segurança. $O$ conhecimento de quando e como serão os níveis de intervenções, determina o sucesso ou fracasso de qualquer técnica aplicada. Os ciclos estabelecidos são suporte para a comparação entre estratégias, definição de desempenho esperado e custos envolvidos (Morian, 2005). A definição da época adequada para manutenção resulta na redução da deterioração do pavimento.

Apesar do sucesso da Road Test, tem-se reafirmado entre projetistas a necessidade de atualizações de modelos de dimensionamento para modelos mecanísticosempíricos. Dentre as exigências para a implementação de modelos atuais encontrase a obtenção de dados confiáveis de desempenho dos pavimentos monitorados, que contemple os materiais e espessura das camadas, clima e tráfego; dados que permitam definir tipos e causas de defeitos (Hallin, 2007). Com este objetivo, o trecho experimental foi monitorado, a fim de se obter indicativos de comportamento e poder estendê-lo, na medida do possível, para outras situações futuras similares do grupo $\mathrm{OHL}$ de rodovias. 
Os dados de monitoramento que serão apresentados nos itens a seguir, não contemplam os segmentos onde a reciclagem foi executada com adição de cal como fíler ativo, conforme exposto na Figura 44. Estes três segmentos deixaram de integrar a pesquisa depois de três meses da execução da camada de rolamento em microrrevestimento, por apresentarem diversos defeitos, possivelmente atribuídos à deficiência dos dispositivos de drenagem, agravado pelo desenho geométrico destes segmentos, em início de curva, diferentemente do restante do trecho experimental, todo em tangente.

Os segmentos sofreram diversas intervenções, sendo impossível para a concessionária, permitir a degradação sem interferência. A Figura 61 apresenta os segmentos reciclados com cal, em dois levantamentos visuais, sendo março/2009, após a restauração do trecho experimental e março/2010, após um ano de vida de serviço, tendo sofrido as diversas intervenções para regularização.
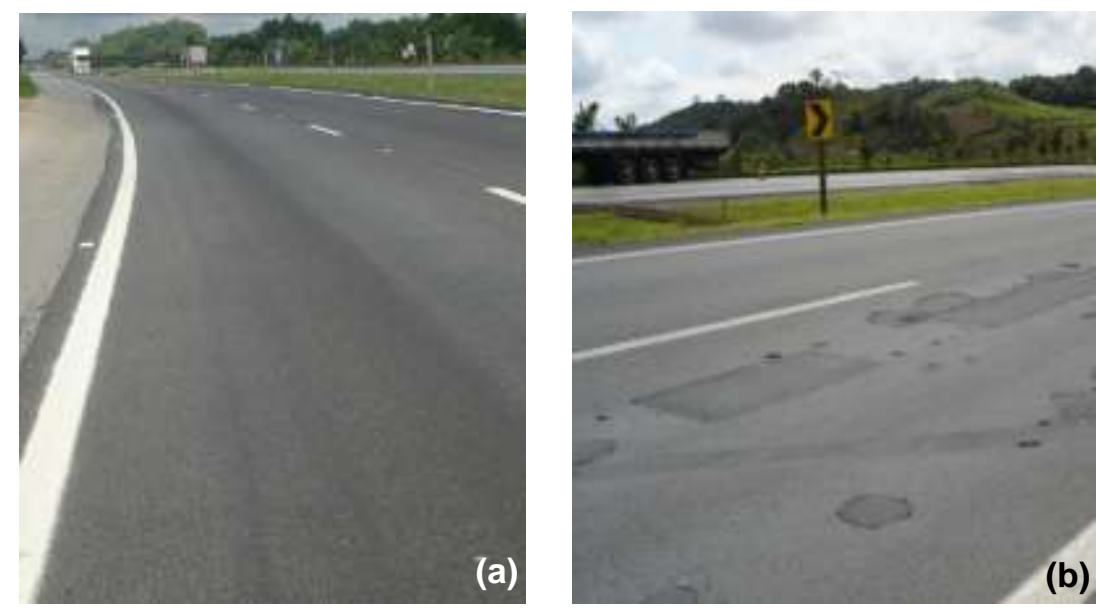

Figura 61 - Segmentos de reciclagem com cal e microrrevestimento, respectivamente em março/2009 (a) e março/2010 (b)

Desta forma, serão apresentados e analisados nesta dissertação, apenas os dados de monitoramento concernentes aos segmentos reciclados com cimento (com camada de revestimento de concreto asfáltico - segmentos $A C+15, A C+11, A C+8-$ e microrrevestimento asfáltico - segmentos MS+15, MS+11, MS+8). 


\subsection{Amostragem do Trecho Experimental}

Foram extraídos posteriormente à execução das camadas de rolamento (aproximadamente três meses), corpos de prova em todos os segmentos, para verificação das espessuras, condição das camadas e eventual densificação. Em cada segmento foram extraídos dois corpos de prova no eixo da faixa e dois corpos de prova na trilha externa (Figura 63). Devido a dificuldades operacionais, poucos corpos de prova resistiram ao processo e permaneceram íntegros. A Figura 62 mostra também três pontos de abertura de janelas, das quais foram extraídos materiais das camadas subjacentes, além de placa para ensaio de deformação permanente em laboratório.

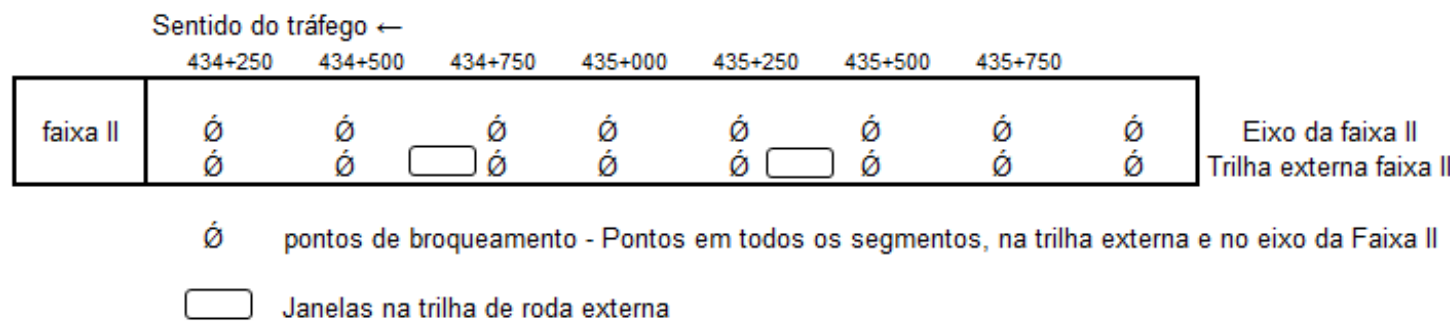

Figura 62 - Representação esquemática dos pontos de extração de corpos-de-prova no trecho experimental
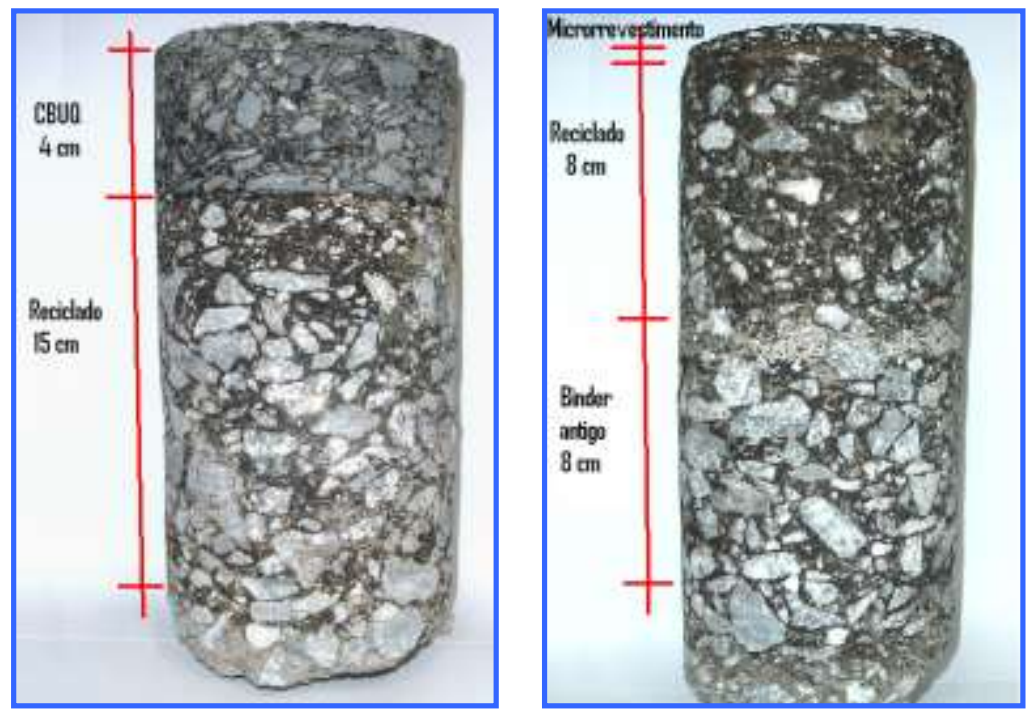

Figura 63 - Corpos-de-prova extraídos por sonda rotativa do trecho experimental indicando as características das estruturas executadas 
Os corpos de prova foram faceados nas extremidades, preservando a mistura reciclada nas dimensões Marshall (63,5 mm X 101,6 mm), conforme Figura 64. O processo de extração, infelizmente, induz fissuras nas laterais do material gerando fragilidade nos corpos de prova que foram submetidos a medidas de densidade, ensaio de abrasão Cântabro, Módulo de Resiliência e Deformação Permanente.
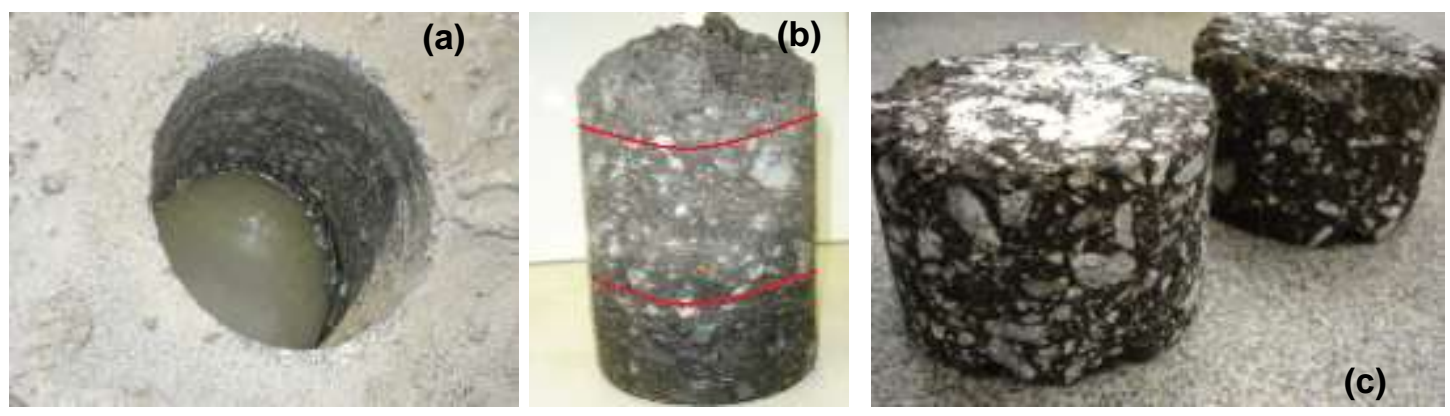

Figura 64 - Local de extração de corpo-de-prova no trecho experimental (a); corpo-de-prova extraído (b) e posteriormente faceado nas dimensões Marshall (c)

As medidas de massa específica aparente pelo método do paquímetro indicaram valor médio de $21,3 \mathrm{kN} / \mathrm{m}^{3}$, mostrando, desta forma, maior densificação em relação aos corpos de prova moldados em laboratório. $O$ ensaio Cântabro foi realizado com apenas dois corpos-de-prova por conta dos resultados obtidos, com perda média de $79 \%$ (Figura 65). Esse resultado reflete duas condições: o ensaio é consideravelmente severo para misturas asfálticas a frio e ainda, que corpos de prova extraídos de campo são muito frágeis, pois além das fissuras laterais da extração, as ligações internas são forçadas durante o processo de remoção do corpo de prova da pista, alterando as características de resistência, não sendo portanto um ensaio conveniente para este material.
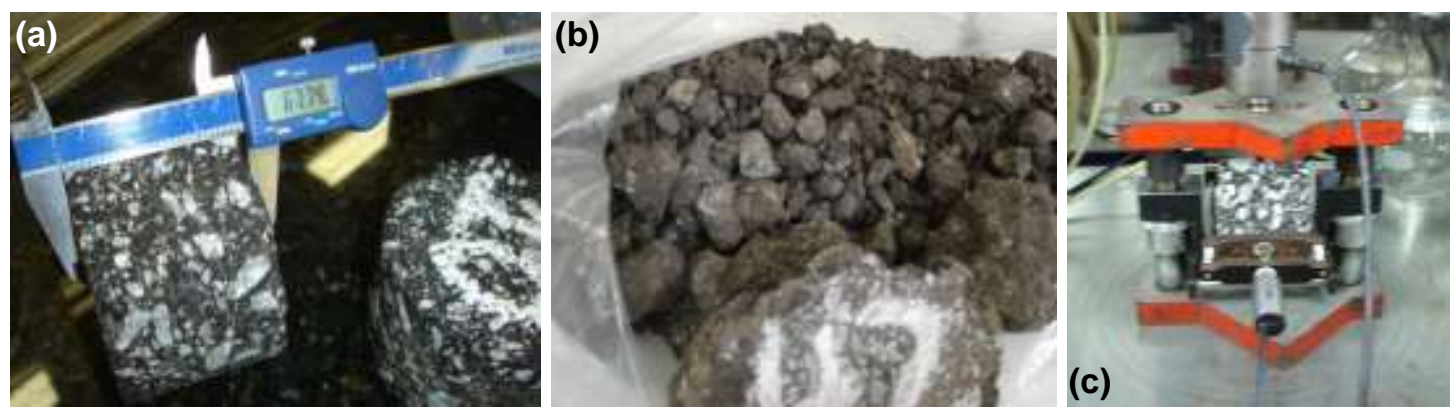

Figura 65 - Corpos-de-prova submetidos a medidas de densidade (a), ensaio Cântabro (b) e ensaio de Módulo de Resiliência (c) 
A realização do ensaio de Módulo de Resiliência atendeu a norma DNER-ME 133/1994 para misturas betuminosas. Esta definição deve-se ao tamanho dos corpos de prova, cortados nas dimensões padrões do ensaio Marshall. Os resultados apresentados na Tabela 15 serão discutidos no item 5.5.3.

Estas amostras representam a condição mais representativa permitindo maior correlação com o material existente em campo, contudo deve-se notar que durante sua extração e preparo para o ensaio, as ligações entre as partículas podem ser perturbadas, alterando a estrutura interna do corpo de prova e sensibilizando sua resistência.

Tabela 15 - Módulo de Resiliência de amostras do trecho experimental

\begin{tabular}{|c|c|c|c|c|c|}
\hline $\mathrm{CP}^{0}$ & 1 & 2 & 3 & 4 & 5 \\
\hline $\mathrm{MR}(\mathrm{MPa})$ & 1.107 & 1.536 & 1.154 & 1.258 & 1.232 \\
\hline
\end{tabular}

Ainda como avaliação de comportamento mecânico, foram realizados ensaios de Deformação Permanente nas placas extraídas do trecho experimental. Da mesma maneira que os corpos de prova extraídos por sonda rotativa, as placas foram faceadas nas medidas apropriadas para serem ensaiadas no Simulador de Tráfego de Laboratório (LPC) (Figura 66).
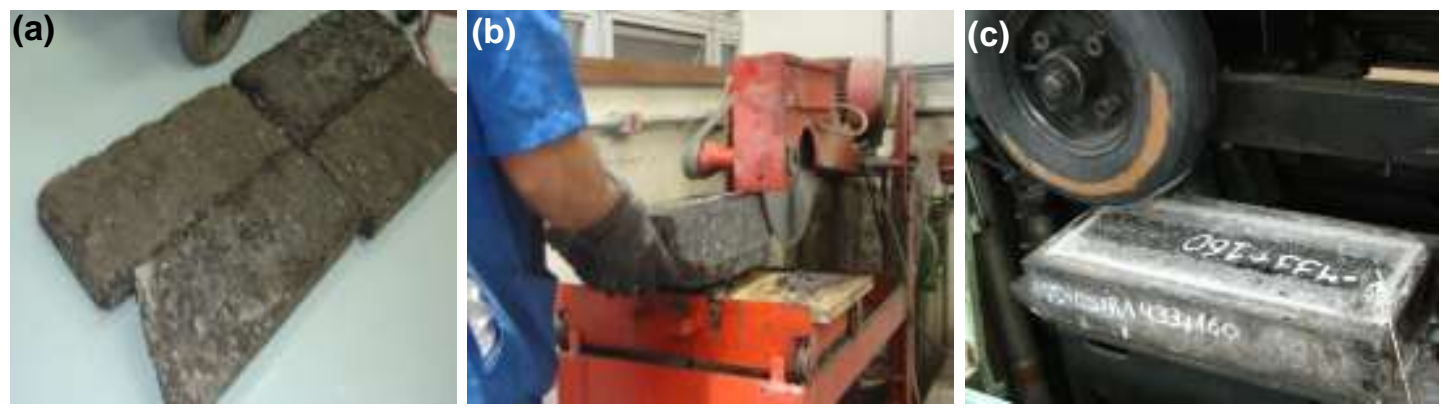

Figura 66 - Placas extraídas do trecho experimental (a), faceadas (b) e ensaiadas no simulador de tráfego tipo LPC de laboratório (c)

Os resultados indicaram deformação permanente máxima de 1,08\%, após 30.000 ciclos mostrando que a mistura não apresenta tendência à deformação permanente, mesmo protegida apenas por camada selante em microrrevestimento. 
A camada reciclada protegida por concreto asfáltico não foi ensaiada no simulador de tráfego devido à espessura máxima de $10 \mathrm{~cm}$ aplicável no simulador. Entretanto o resultado da simulação em amostras com camada de revestimento em microrrevestimento é suficiente para confirmar os resultados obtidos com uso do simulador de tráfego em escala real, e os resultados do monitoramento das condições de superfície no trecho experimental.

\subsection{Condição de Superfície}

O trecho experimental foi monitorado em suas condições de superfície por meio de levantamento de irregularidade longitudinal com o perfilômetro laser DYNATEST 5051 Mk-III RSP, em quatro campanhas, sendo realizadas nas seguintes épocas: (i) em outubro/2008, antes da restauração por meio de reciclagem, (ii) em março/2009, após a conclusão dos trabalhos de restauração, incluindo execução das camadas de revestimento, (iii) em março/2010, após um ano da conclusão dos trabalhos de restauração, completando um período seco e um chuvoso e, (iv) em fevereiro/2011, após dois anos de vida em serviço. Os resultados são apresentados separadamente entre faixa I (Figura 67) e faixa II (Figura 68) de rolamento, sendo esta segunda a faixa de veículos mais lentos e comerciais.

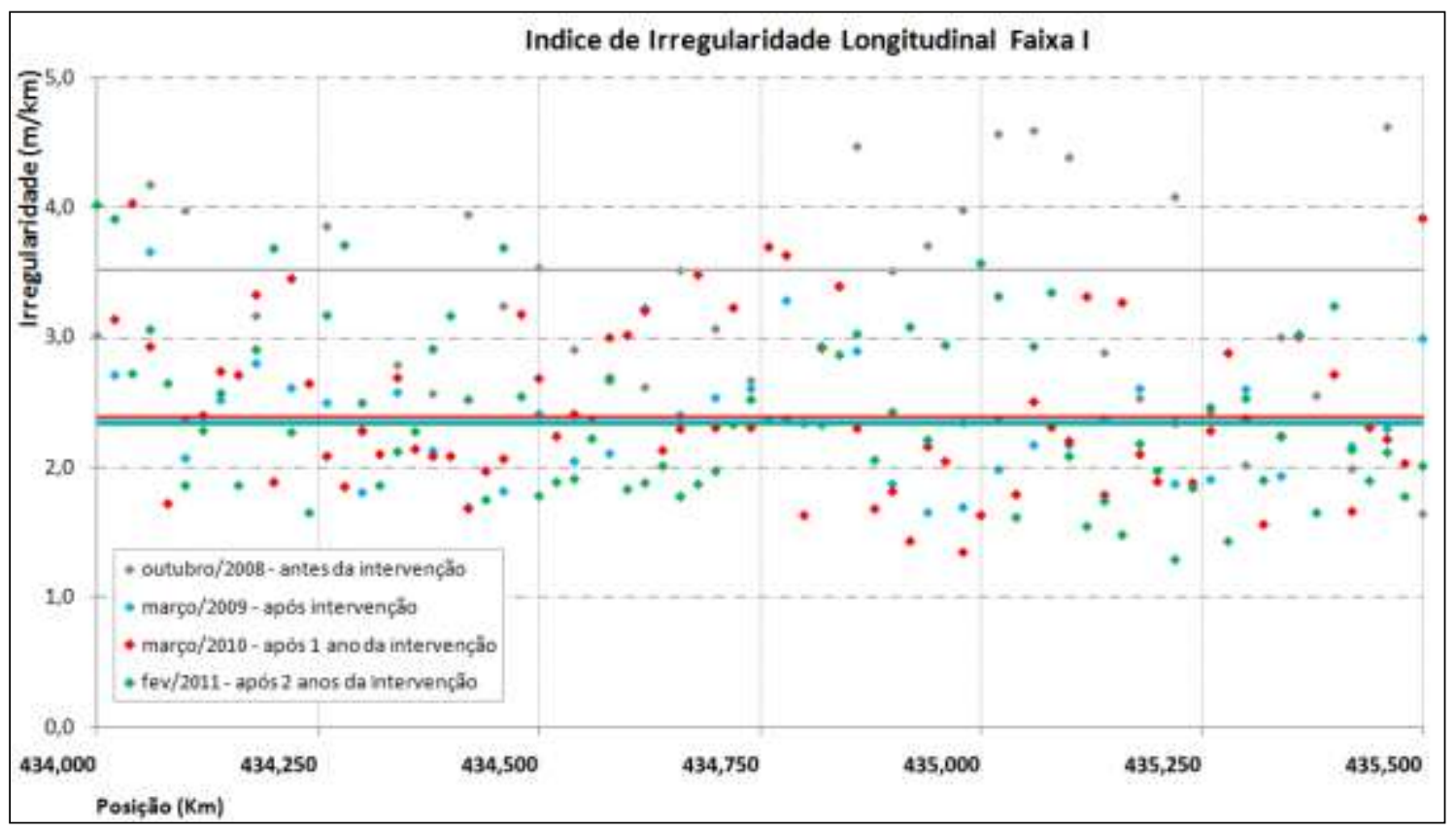

Figura 67 - Índice de Irregularidade Longitudinal - Faixa I 


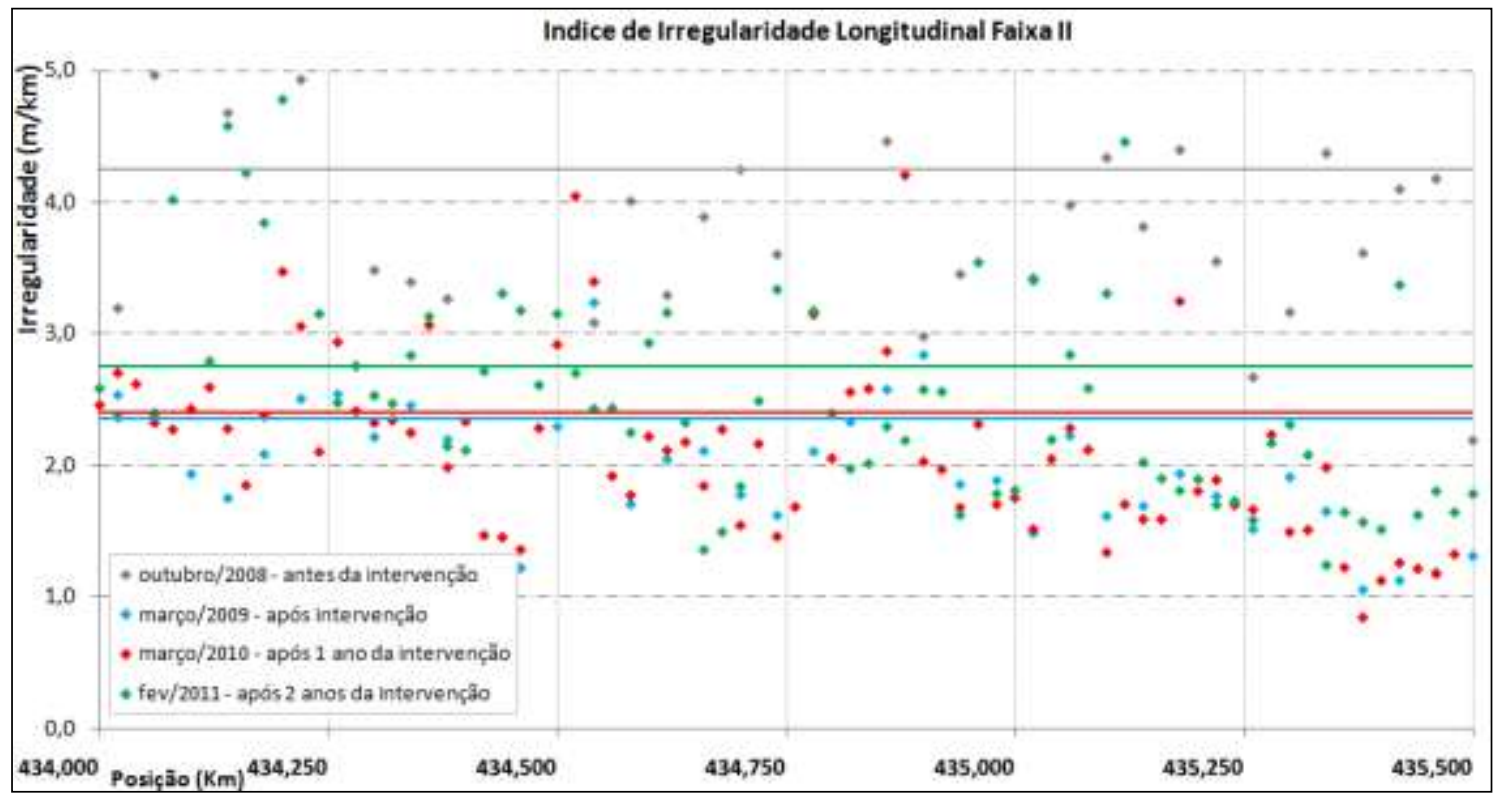

Figura 68 - Índice de Irregularidade Longitudinal - Faixa II

As avaliações dos indicativos de desempenho são apresentadas apenas para a faixa I, uma vez que a faixa II teve o tráfego interrompido durante um longo período para realização de ensaios com simulador de tráfego. Os resultados médios dos levantamentos de irregularidade longitudinal são apresentados na Figura 69 para a faixa I, em cada campanha realizada. Observa-se que houve considerável melhoria das condições de trafegabilidade do pavimento após a restauração por meio de reciclagem. Essa melhoria resistiu muito bem até o segundo ano. Limite 2,7 m/km

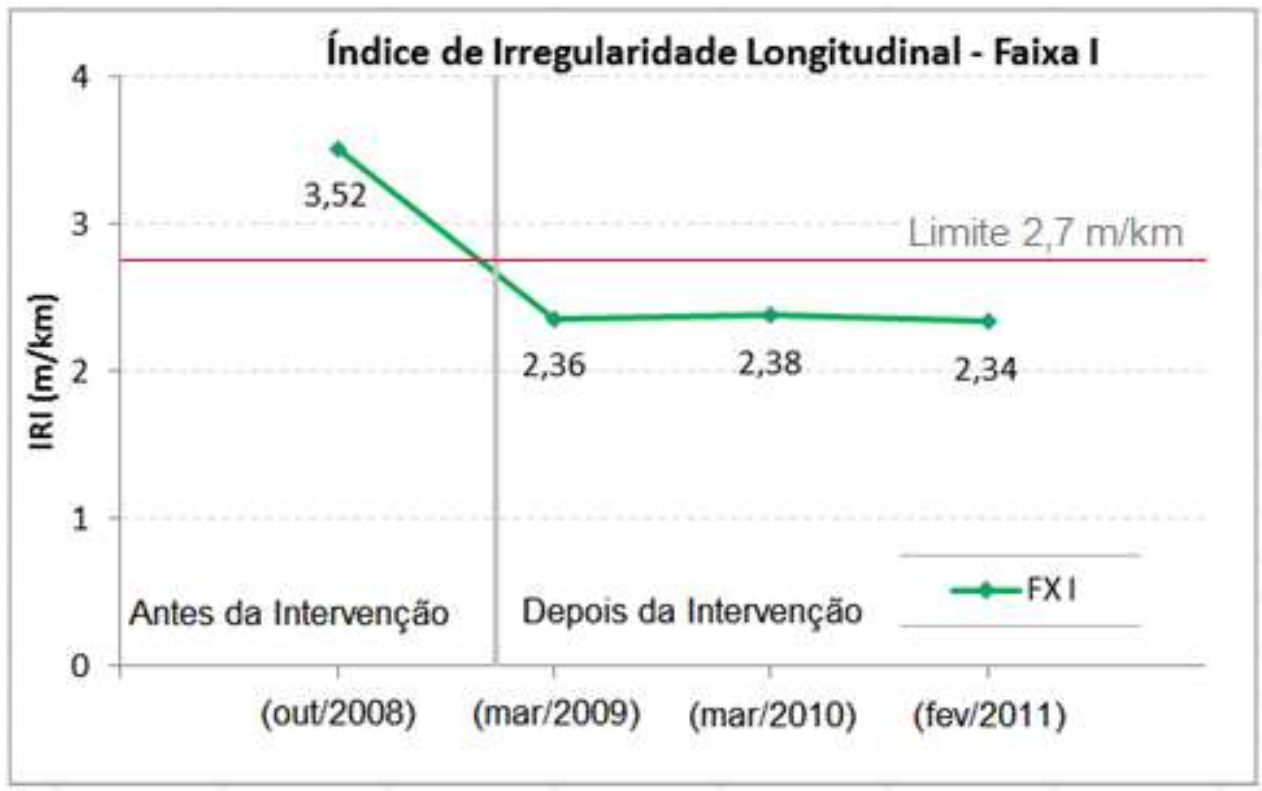

Figura 69 - Irregularidade longitudinal na faixa I do trecho experimental 
O desvio padrão é de $1,1 \mathrm{~m} / \mathrm{Km}$ em outubro/2008, de $0,47 \mathrm{~m} / \mathrm{Km}$ em março/2009, de $0,67 \mathrm{~m} / \mathrm{Km}$ em março/2010 e de 0,60 m/Km em fevereiro/2011. Como avaliação de condição de superfície, foi realizado Levantamento Visual Contínuo, periodicamente, sendo que as principais épocas de análise são março/2009 e março/2010, da mesma forma que ocorreu nos levantamentos de irregularidade, apresentados acima.

Os dados de monitoramento não incluem os segmentos reciclados com cal, conforme mencionado anteriormente. A Figura 70 mostra o aspecto do trecho experimental imediatamente após a conclusão dos trabalhos de restauração por meio de reciclagem e colocação de camada de revestimento.
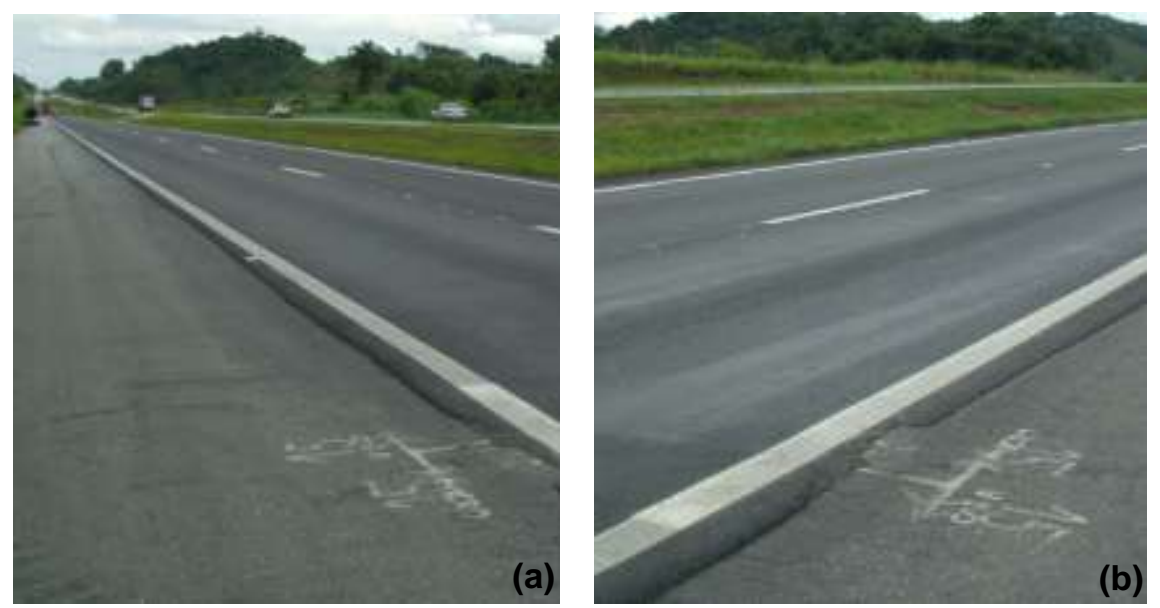

Figura 70 - Segmentos reciclados com cimento e camada de revestimento em concreto asfáltico (a) e em microrrevestimento (b), respectivamente - Imediatamente após restauração março/2009

No período de um ano, o trecho experimental sob elevado tráfego atuante, não apresentou deterioração significativa visualmente, resultando em constante nível de conforto ao rolamento, conforme se verifica na Figura 71. Tanto os segmentos com camada de rolamento de concreto asfáltico, quanto os de microrrevestimento asfáltico, apresentam bom desempenho nas condições de superfície. 

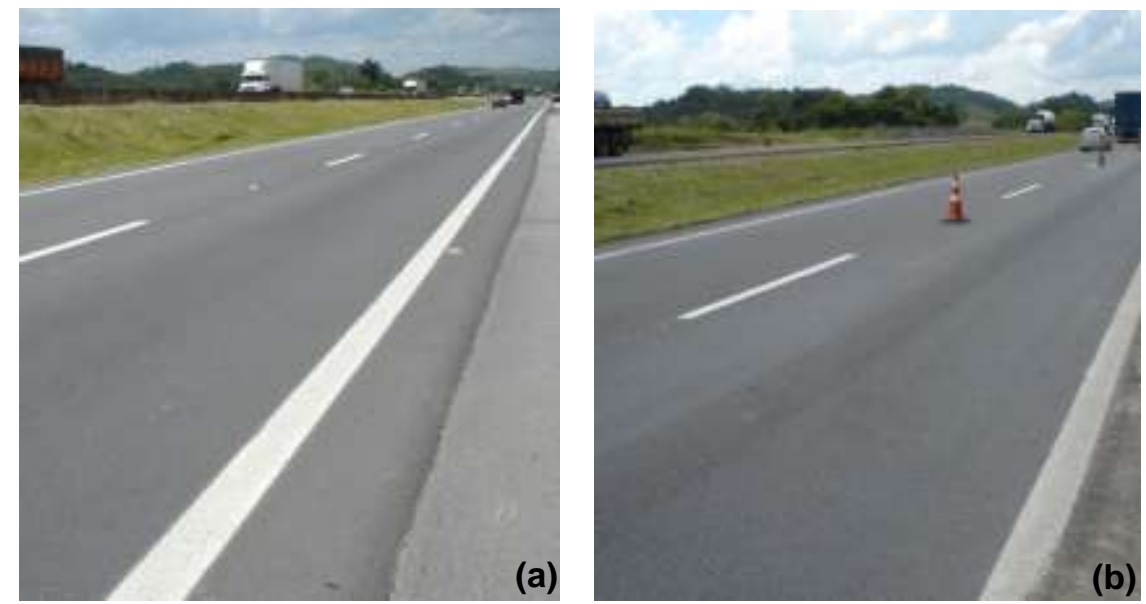

Figura 71 - Segmentos reciclados com cimento e camada de revestimento em concreto asfáltico (a) e em microrrevestimento (b), respectivamente - após um ano de vida em serviço março/2010

\subsection{Simulador de Tráfego em Escala Real}

A reciclagem de pavimentos é um processo recente no Brasil, sem muitos estudos que possam ser suficientes para definir condições de aplicação em função dos resultados apresentados. É uma tecnologia relativamente nova sem avaliação de desempenho por modelos que apresentem confiabilidade ou procedimentos para avaliação e determinação de vida útil através de ensaios acelerados.

Modelos de previsão de desempenho são muito importantes no sistema de gerência de pavimentos, para tanto são necessários métodos de calibração e validação desses modelos e que os modelos sejam representativos das condições funcionais e estruturais.

O uso de equipamento simulador de tráfego em escala real acelera a obtenção dos resultados, uma vez que o equipamento impinge à estrutura os esforços de um semi-eixo de rodas duplas simulando um veículo comercial em sucessivas passagens definidas como ciclos. O processo ininterrupto abrevia o período necessário para avaliação de desempenho deste pavimento. Entretanto, o equipamento apresenta uma série de variáveis que o distingue do tráfego real, implicando, conseqüentemente, em resultados que devem ser empregados para inferência do comportamento real. 
O Simulador de Tráfego HVS - Heavy Vehicle Simulator (Figura 72) consiste de um semi-eixo rodoviário com rodas duplas e cargas de até $8 \mathrm{tf}$, o qual corresponde a um eixo simples de rodas duplas com carga total de até $16 \mathrm{tf}$, que se movimenta no sentido longitudinal com deslocamentos de até $9 \mathrm{~m}$ e, transversalmente, até $1 \mathrm{~m}$ de largura, com capacidade de executar 1000 passagens ou aplicações de carga em uma determinada área da seção de ensaio por dia. Dessa forma, a combinação da velocidade de deslocamento longitudinal do semi-eixo com os demais recursos do equipamento, ou seja, deslocamento transversal e carga aplicada permitem reproduzir em curtos períodos de tempo e com bastante aproximação da realidade as conseqüências da ação das cargas do tráfego nas estruturas de pavimento.

Segundo Pinto (1991), em função do grande número de variáveis que afeta a vida de fadiga, os resultados obtidos devem ser colocados de forma estatística, advertindo que os danos causados pelo equipamento simulador de tráfego são indicativos de comportamento, mas não conclusivos. Além disso, a compreensão dos dados depende da ponderação entre os dados de tráfego e do simulador, sem que haja necessariamente uma relação de equivalência entre ambos.
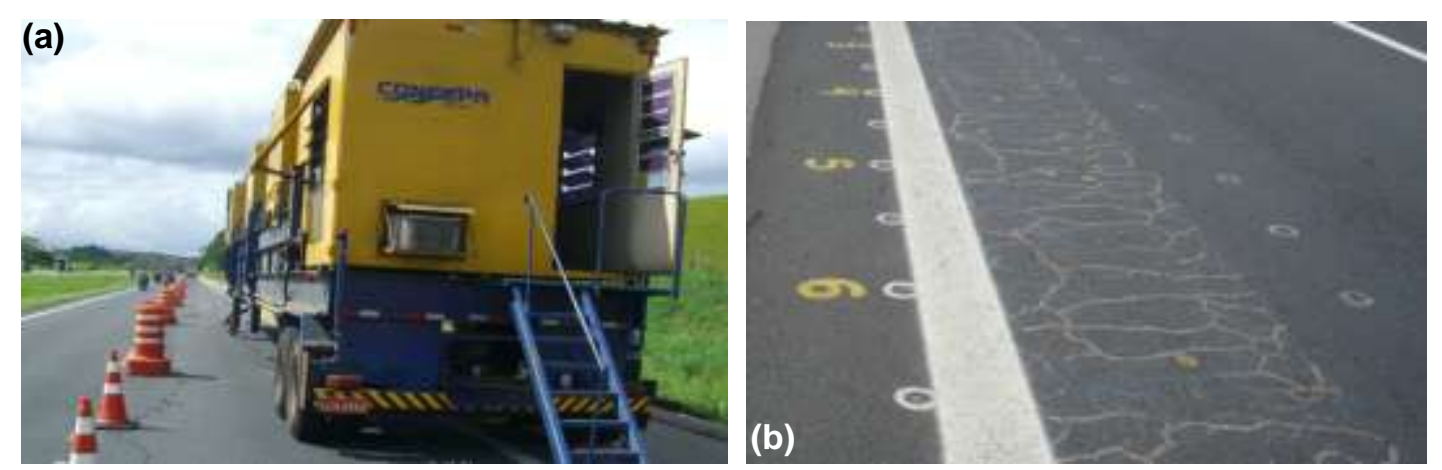

Figura 72 - Simulador de Tráfego instalado no Trecho Experimental (a); segmento submetido ao ensaio (b)

Os resultados obtidos a partir do uso do simulador de tráfego não foram considerados conclusivos para a definição da vida de fadiga do material, no entanto apontaram alguns aspectos que devem ser controlados para correta interpretação de resultados, tais como carga aplicada e registros de condições climáticas, que alteraram o comportamento. O uso do simulador de tráfego móvel ratificou a informação obtida por meio do simulador de tráfego de laboratório, de que a mistura 
reciclada não apresenta tendência substancial à deformação permanente. Deformação permanente é um defeito importante no desempenho do pavimento, ao qual todas as camadas estão sujeitas, independente de ter deformação da camada do revestimento.

Durante a realização da simulação de tráfego, o equipamento esteve instalado na faixa de veículos pesados (Faixa II), durante nove meses do primeiro ano (entre abril e dezembro de 2009), fator que implicou no desvio total do tráfego para a faixa I. A Figura 73 apresenta esquematicamente o desvio.

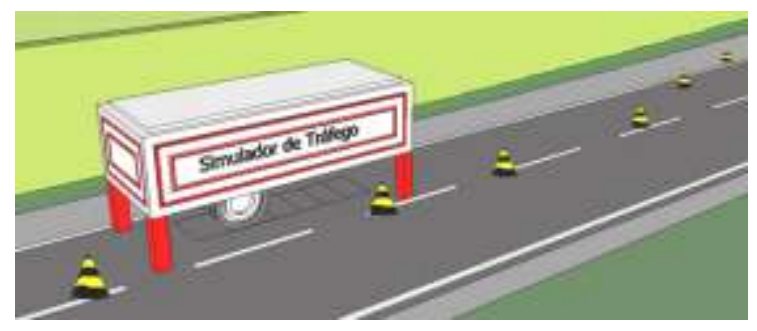

Figura 73 - Simulador de Tráfego instalado na Faixa II - desvio de tráfego

Ponderações foram feitas no cálculo no número de repetições de carga $\mathrm{N}$ atuante, em relação ao período de desvio, nove meses, sendo o tráfego canalizado na faixa I. As avaliações que serão descritas nos itens seguintes, consideram a deterioração na faixa I, para a qual o tráfego foi desviado. Contudo, os resultados de monitoramento são apresentados para ambas as faixas de rolamento.

\subsection{Deflexões do Pavimento do Trecho Experimental}

O monitoramento das condições estruturais ocorreu por meio de medidas deflectométricas periódicas realizadas com equipamento FWD (Falling Weight Deflectometer). As campanhas foram realizadas nas seguintes épocas e condições: (i) outubro/2008, antes da restauração por reciclagem, (ii) março/2009, imediatamente após conclusão dos trabalhos de restauração, em final de período chuvoso, (iii) março/2010, medida correlata com março/2009, em final de período chuvoso e, (iv) fevereiro/2011, período chuvoso. 
Foram realizadas também medições intermediárias nos meses de junho/2009 e junho/2010, meses com baixa precipitação e baixas temperaturas, resultando em menores deflexões. Estas medidas foram utilizadas na definição da média anual em conjunto com as medidas relativas a março/2009 e março/2010, respectivamente. As medidas relativas a junho tiveram correção sazonal de acordo com o método de projeto PRO 11/79, para subleito de natureza arenoso e permeável (Tabela 16).

Tabela 16 - Fator de correção sazonal - DNER PRO 11/1979

\begin{tabular}{|c|c|c|}
\hline \multicolumn{3}{|c|}{ Fator de Correção Sazonal } \\
\hline Natureza do Subleito & Estação Seca & Estação Chuvosa \\
\hline Arenoso e Permeável & $1,10-1,30$ & 1,00 \\
\hline Argiloso e Sensível à Umidade & $1,20-1,40$ & 1,00 \\
\hline
\end{tabular}

As medições foram realizadas pela empresa Dynatest, com equipamentos calibrados; os valores foram corrigidos pela temperatura e pela carga, e são apresentados nas Figura 74 (faixa I) e Figura 75 (faixa II).

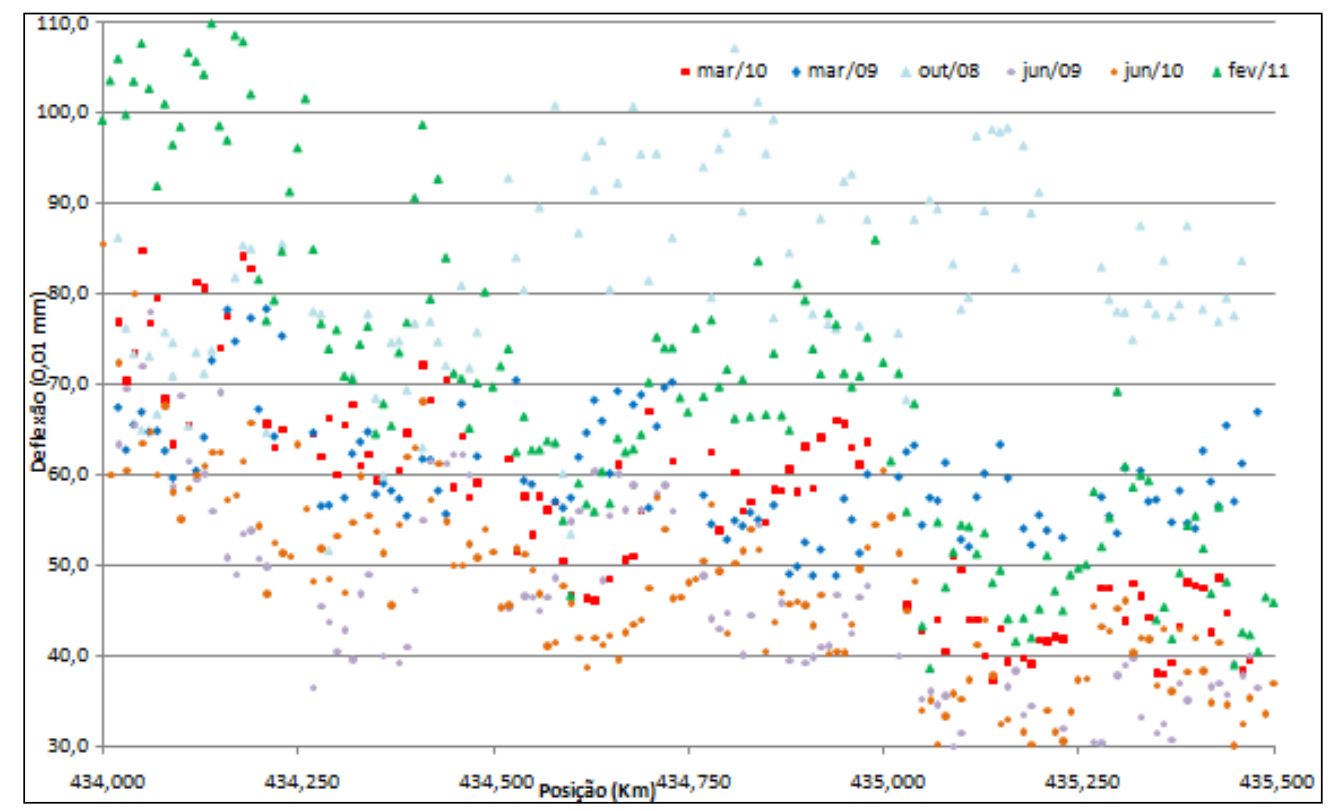

Figura 74 - Medidas deflectométricas para todas as campanhas realizadas no período da pesquisa na faixa I do trecho experimental 


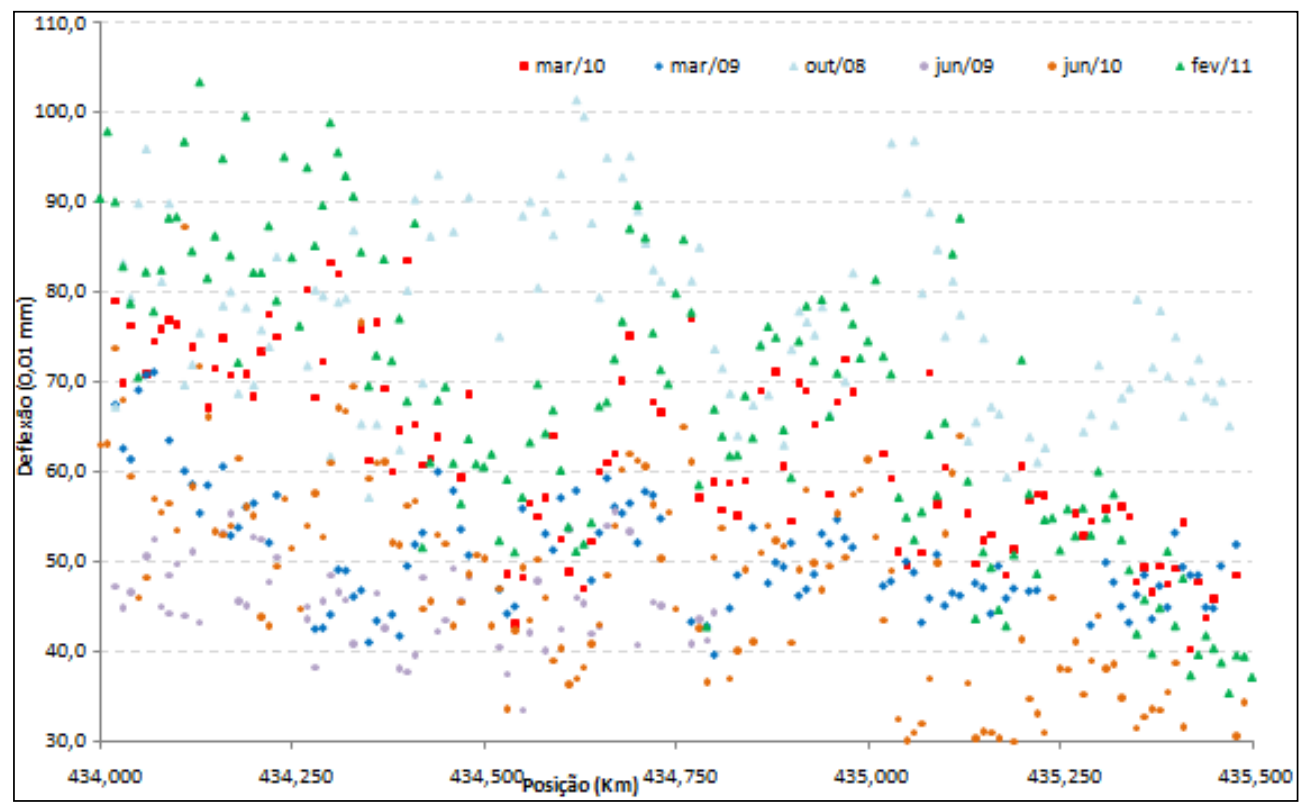

Figura 75 - Medidas deflectométricas para todas as campanhas realizadas no período da pesquisa na faixa II do trecho experimental

Conforme mencionado anteriormente, a faixa II esteve fechada ao tráfego em alguns períodos da pesquisa, de modo que a análise do desempenho do trecho experimental se restringe a faixa $\mathrm{I}$, que recebeu o tráfego regularmente. As proporções das médias deflectométricas apresentadas a seguir, referem-se aos segmentos com camada de revestimento em microrrevestimento, permitindo conhecer o benefício estrutural da camada reciclada, exclusivamente, sem influência da camada de CBUQ.

A Figura 76 apresenta a proporção de faixas de deflexão medidas no trecho experimental em quatro campanhas para a faixa I, de modo que se percebe 0 aumento da deflexão em todo o trecho. As medidas relativas a outubro/2008 - antes da intervenção revelam deflexões elevadas, a maior parte entre $70(0,01 \mathrm{~mm})$ e 90 $(0,01 \mathrm{~mm})$, valores que indicam deficiência estrutural. 


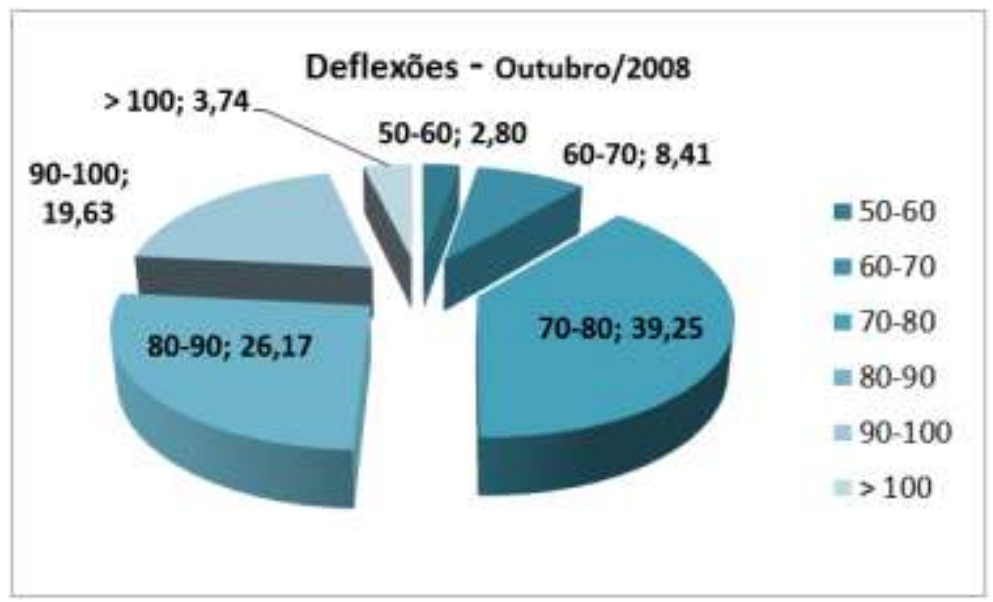

Figura 76 - Proporção de faixas de deflexão no trecho experimental - Faixa I - Outubro/2008 antes da intervenção

As medidas relativas a março/2009 (Figura 77) - após a intervenção indicam redução considerável das deflexões, com maior parte das medidas entre 50 e 70 $(0,01 \mathrm{~mm})$, tendo poucas medidas chegando a $80(0,01 \mathrm{~mm})$; estes resultados mostram que a mistura reciclada atua incrementando a resistência estrutural do pavimento. O benefício da substituição de uma camada trincada por uma camada íntegra, é funcional e estrutural.

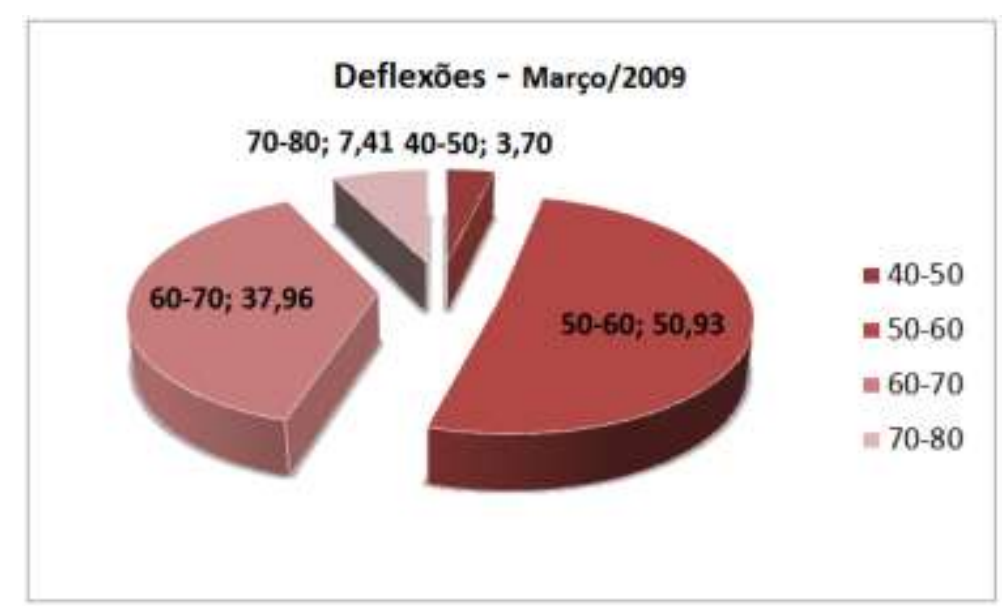

Figura 77 - Proporção de faixas de deflexão no trecho experimental - Faixa I - Março/2009 após a intervenção

As medidas de março/2010 (Figura 78) revelam aumento das deflexões máximas, tendo poucas medidas alcançando $90(0,01 \mathrm{~mm})$. Em contrapartida às deflexões máximas, foram registradas deflexões mais baixas, entre 30 e 40, que não haviam sido registradas imediatamente após a restauração (março/2009). As deflexões mais 
altas estão associadas à deterioração da camada reciclada, após um ano de tráfego atuante elevado. As deflexões mais baixas podem estar relacionadas a dois fatores: (i) maior dispersão de resultados, pela menor homogeneidade do material e, (ii) por influência de um período chuvoso com menor índice pluviométrico.

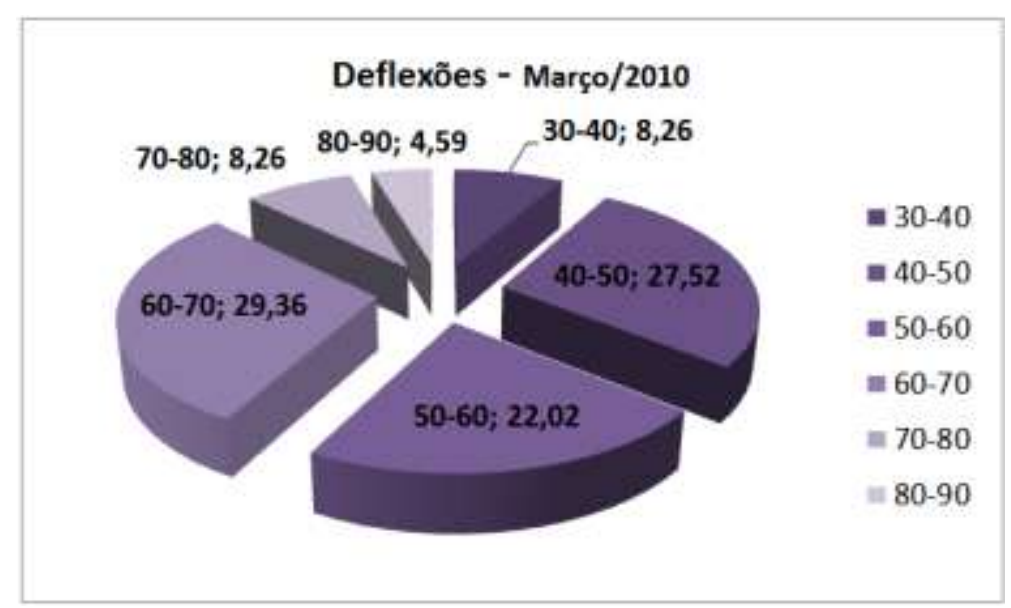

Figura 78 - Proporção de faixas de deflexão no trecho experimental - Faixa I - Março/2010 após um ano da intervenção

As medidas realizadas em fevereiro/2011 (Figura 79) mostram maior dispersão de resultados, além de maiores deflexões máximas, dois fatores que indicam a maior deterioração da camada reciclada, tendo sua resistência estrutural reduzida. Os dados apresentados no item 5.2, não mostraram condição superficial consideravelmente prejudicada na faixa I, contudo, os dados de deflexão indicam que a deterioração estrutural tem avançado de forma mais evidente.

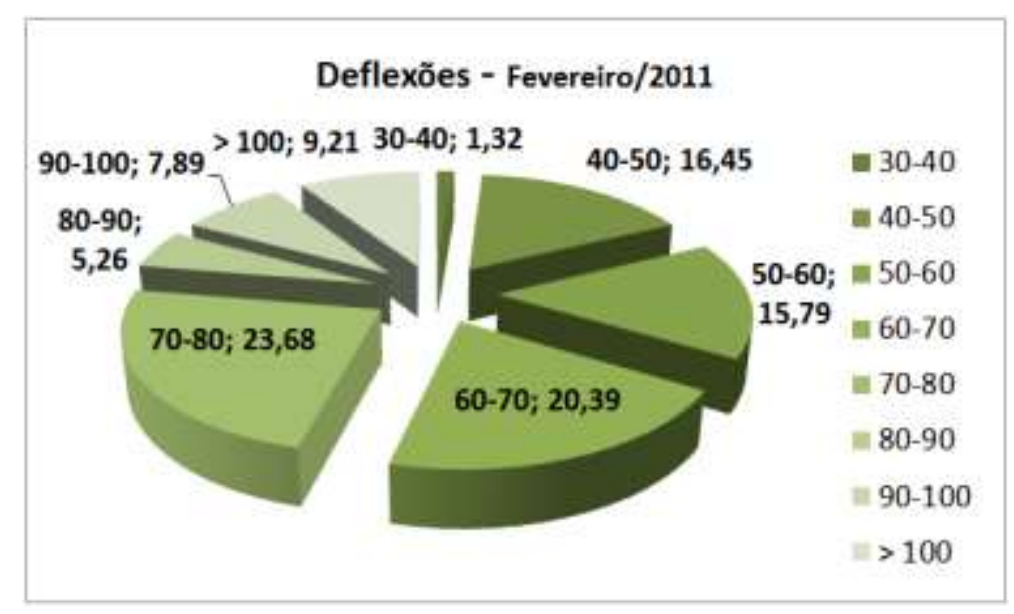

Figura 79 - Proporção de faixas de deflexão no trecho experimental - Faixa I - Fevereiro/2011 após dois anos da intervenção 
A Tabela 17 apresenta os valores de deflexão média, desvio padrão e coeficiente de variação das medidas deflectométricas de cada segmento, apresentadas na Figura 44.

Tabela 17 - Resumo das médias e desvio padrão das medidas de deflexão

\begin{tabular}{|c|c|c|c|c|c|c|c|c|}
\hline & $A C+8$ & $A C+11$ & $A C+15$ & $M S+15$ & $M S+11$ & $\mathrm{MS}+8$ \\
\hline & & & $435+500$ & $435+250$ & $435+000$ & $434+750$ & $434+500$ & $434+250$ \\
\hline \multirow{3}{*}{$\begin{array}{l}\text { Antes da } \\
\text { Intervenção }\end{array}$} & \multirow{3}{*}{ out/08 } & Média & 80,1 & 87,9 & 89,0 & 86,9 & 72,0 & 74,9 \\
\hline & & Desv. Padrão & 3,7 & 8,8 & 9,6 & 12,7 & 7,4 & 7,3 \\
\hline & & coef. Variação & 0,046 & 0,100 & 0,108 & 0,147 & 0,103 & 0,097 \\
\hline \multirow{9}{*}{$\begin{array}{c}\text { Após } \\
\text { Intervenção }\end{array}$} & \multirow{3}{*}{$\mathrm{mar} / 09$} & Média & 47,1 & 47,4 & 50,6 & 59,1 & 53,0 & 66,4 \\
\hline & & Desv. Padrão & 3,0 & 3,9 & 4,2 & 4,4 & 3,4 & 2,8 \\
\hline & & coef. Variação & 0,064 & 0,082 & 0,083 & 0,074 & 0,064 & 0,043 \\
\hline & \multirow{3}{*}{$\mathrm{mar} / 10$} & Média & 46,3 & 44,9 & 58,4 & 57,0 & 61,9 & 69,3 \\
\hline & & Desv. Padrão & 3,5 & 3,5 & 4,9 & 4,0 & 4,2 & 5,0 \\
\hline & & coef. Variação & 0,075 & 0,079 & 0,085 & 0,070 & 0,068 & 0,072 \\
\hline & \multirow{3}{*}{ fev/11 } & Média & 51,0 & 50,5 & 73,2 & 64,1 & 77,1 & 98,6 \\
\hline & & Desv. Padrão & 7,7 & 7,8 & 5,6 & 7,0 & 10,1 & 9,4 \\
\hline & & coef. Variação & 0,151 & 0,155 & 0,077 & 0,109 & 0,131 & 0,095 \\
\hline
\end{tabular}

Os valores apresentados são indicativos do desempenho de cada segmento. A avaliação do desempenho em função da variação da camada de revestimento foi realizada através de análise comparativa de cada segmento. A Figura 80 apresenta a comparação do desempenho durante o período da pesquisa, nos segmentos com camada reciclada em $8 \mathrm{~cm}$ e com camada de revestimento em CBUQ (Segmento $\mathrm{AC}+8$ ) e Microrrevestimento (Segmento MS+8). O segmento que recebeu microrrevestimento apresentou aumento muito expressivo nas medidas de deflexão, contudo cabe lembrar que este segmento é adjacente aos segmentos reciclados com cal, que foram excluídos da pesquisa por apresentar uma série de defeitos atribuídos à drenagem deficiente. 


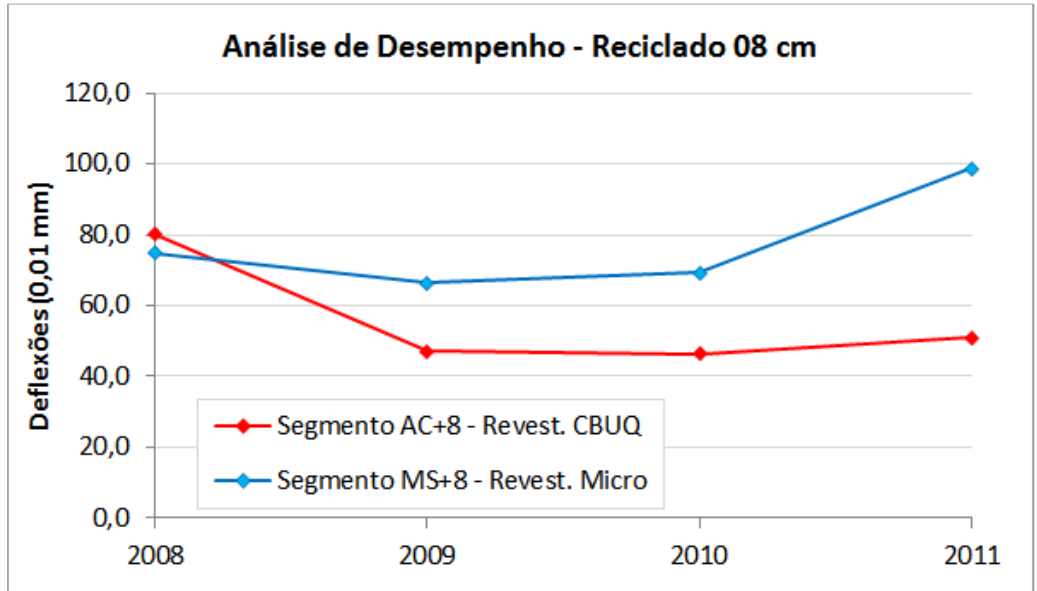

Figura 80 - Análise de desempenho dos segmentos reciclados em $8 \mathrm{~cm}$ de espessura

A Figura 81 apresenta a comparação do desempenho durante o período da pesquisa, nos segmentos com camada reciclada em $11 \mathrm{~cm}$ e com camada de revestimento em CBUQ (Segmento $A C+11$ ) e Microrrevestimento (Segmento MS+11). Percebe-se aumento significativo nas deflexões do segmento revestido em microrrevestimento, que pode ser ainda efeito da drenagem deficiente, mas que indica redução na vida útil da estrutura. Após o primeiro ano de vida de serviço do pavimento, a deflexão teve aumento muito acelerado nas deflexões. A implantação de camada de revestimento mais espessa após um ano, pode ser uma alternativa, porém é uma solução que deve ser estudada e vinculada às deflexões.

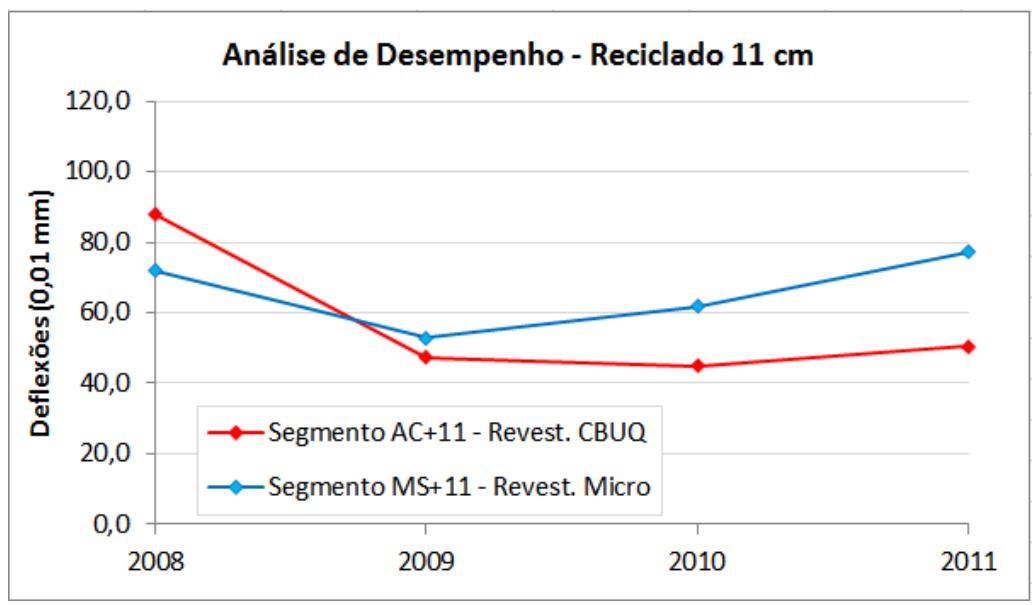

Figura 81 - Análise de desempenho dos segmentos reciclados em $11 \mathrm{~cm}$ de espessura

A Figura 82 apresenta a comparação do desempenho durante o período da pesquisa, nos segmentos com camada reciclada em $15 \mathrm{~cm}$ e com camada de 
revestimento em CBUQ (Segmento $\mathrm{AC}+15$ ) e Microrrevestimento (Segmento MS+15).

A redução nas medidas de deflexão não é mais significativa nestes segmentos, após a restauração do que nos segmentos com menores espessuras recicladas. Esse dado indica que a mistura reciclada em $15 \mathrm{~cm}$ de espessura tem maior defasagem no desempenho, podendo ser atribuída à redução da eficiência de compactação, porém não há confirmação desta hipótese.

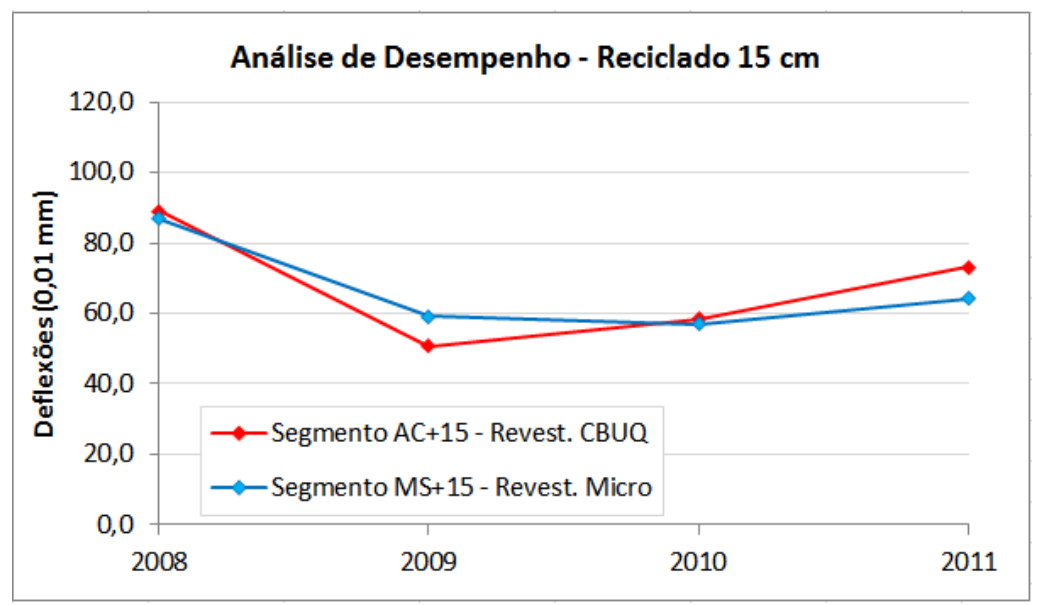

Figura 82 - Análise de desempenho dos segmentos reciclados em $15 \mathrm{~cm}$ de espessura

Os segmentos que receberam camada de revestimento em CBUQ mostram tendência de aumento menos acentuado das deflexões, em relação aos segmentos que receberam microrrevestimento como camada selante. A utilização de camada usinada densa, mesmo com espessura reduzida de $4 \mathrm{~cm}$, exceto no caso da camada reciclada em $15 \mathrm{~cm}$ que mostrou comportamento deflectométrico similar, em material mais resistente indica melhor desempenho da estrutura, protegendo a camada reciclada.

O desempenho na extremidade próxima aos segmentos reciclados com cal $(434+000)$ que foram excluídos por defeitos precoces atribuídos à deficiência de drenagem, também apresentaram elevação mais acentuada de deflexões que podem estar também associadas à mesma deficiência de drenagem. Como o segmento com cimento, imediato aos segmentos reciclados com cal ainda não apresentou problemas evidentes como o segmento com cal, em análise inicial os 
resultados podem ser atribuídos ao conjunto de deficiência de drenagem e estrutura com camada selante (sem beneficio estrutural).

\subsubsection{Avaliação pelo Método DNER - PRO 11/79}

O método DNER PRO 11/1979 define espessuras de reforço a partir das deflexões máximas medidas no pavimento, da característica do material e do número $\mathrm{N}$ de solicitações do eixo padrão a que o pavimento deve resistir.

\subsubsection{Fator de Redução de Deflexão}

Foi calculado o valor característico do fator de redução de deflexão $\mathrm{K}$ da mistura reciclada, conforme Eq. (2), que pôde ser calibrado em função das três espessuras aplicadas em campo. A deflexão máxima no topo da camada fresada (Do antes), para cada espessura, foi obtida por meio de retroanálise.

$$
h=K * \log \left(\frac{D_{\text {antes }}}{D_{\text {adm }}}\right)
$$

Com a finalidade de ampliação do universo de resultados, os cálculos contemplaram o uso da deflexão média e do desvio padrão, permitindo estabelecer valores mais amplos, dadas as variáveis aplicadas no trecho experimental. As deflexões de campo obtidas por meio do equipamento FWD, foram admitidas como deflexão admissível, e utilizados apenas os dados dos segmentos com camada de microrrevestimento, por ser uma camada desprezível do ponto de vista estrutural. Estes dados de deflexão devem ser ponderados, pois existem variáveis que interferem diretamente nos resultados. A Tabela 18 apresenta os valores do fator de redução de deflexão obtido para cada segmento com camada em microrrevestimento. 
Tabela 18 - Valores do coeficiente K para misturas asfálticas recicladas

\begin{tabular}{|c|c|c|c|}
\hline $\begin{array}{c}\text { Espessura de } \\
\text { reforço }(\mathrm{h})\end{array}$ & \multicolumn{2}{|c|}{$\begin{array}{c}\text { Deflexão admissível } \\
\text { aplicada }\end{array}$} & $\mathrm{K}$ \\
\hline \multirow{3}{*}{$\begin{array}{c}8 \mathrm{~cm} \\
\mathrm{MS}+8\end{array}$} & $\mathrm{D}_{0}-\sigma$ & 60,8 & 29,0 \\
\cline { 2 - 4 } & $\mathrm{D}_{0}$ & 69,3 & 36,4 \\
\cline { 2 - 4 } & $\mathrm{D}_{0}+\sigma$ & 77,7 & 47,0 \\
\hline \multirow{3}{*}{$\begin{array}{c}11 \mathrm{~cm} \\
M S+11\end{array}$} & $\mathrm{D}_{0}-\sigma$ & 56,0 & 29,1 \\
\cline { 2 - 4 } & $\mathrm{D}_{0}$ & 61,2 & 32,3 \\
\cline { 2 - 4 } & $\mathrm{D}_{0}+\sigma$ & 66,4 & 36,1 \\
\hline \multirow{3}{*}{$\begin{array}{c}15 \mathrm{~cm} \\
M S+15\end{array}$} & $\mathrm{D}_{0}-\sigma$ & 57,9 & 35,6 \\
\cline { 2 - 4 } & $\mathrm{D}_{0}$ & 63,8 & 39,6 \\
\cline { 2 - 4 } & $\mathrm{D}_{0}+\sigma$ & 69,7 & 44,0 \\
\hline
\end{tabular}

Observa-se, por exemplo, que os valores médios de deflexão para o segmento com camada reciclada em $11 \mathrm{~cm}$ são mais baixos do que os demais. Isso pode ser devido à influência do módulo da estrutura remanescente, que em maior proporção na estrutura de $8 \mathrm{~cm}$ de camada reciclada, reduz consideravelmente o módulo do conjunto, e que na estrutura com $11 \mathrm{~cm}$ de camada reciclada, não reduz da mesma forma. A diferença em relação ao segmento com camada reciclada em $15 \mathrm{~cm}$ pode estar justamente na ausência de camada remanescente (mistura asfáltica trincada), sendo o módulo integral da mistura reciclada.

Os valores finais de $\mathrm{K}$ também devem ser ponderados em função da deflexão antes, obtida por retroanálise, sendo que estes resultados são considerados estimativas.

Como resultado final, encontram-se valores entre 29 e 47 (média de 32 a 40), ambos os extremos presentes no segmento com camada reciclada em $8 \mathrm{~cm}$, denotando a possível influência da variabilidade do módulo de camada remanescente (maior desvio padrão). Além disso, é possível que este segmento tenha apresentado maiores deflexões desde a restauração, por deficiência de drenagem percebida nos segmentos reciclados com cal, anteriormente mencionados.

O coeficiente $\mathrm{K}$ para concreto asfáltico, adotado como 40 no procedimento PRO $11 / 79$ é superior aos valores médios calculados (32 a 40) para a mistura reciclada a 
frio. Contudo estima-se que o comportamento das misturas recicladas seja intermediário entre um concreto asfáltico e uma camada granular, conforme citado anteriormente. Os resultados para o coeficiente $\mathrm{K}$ apresentados na Tabela 18 mostram que não são representativos do comportamento de misturas recicladas a frio.

\subsubsection{Raio de Curvatura da Bacia de Deflexão}

O raio de curvatura da bacia de deflexão é um parâmetro muito difundido no Brasil, como indicativo de desempenho do pavimento em função das medidas de deflexão. A fórmula utilizada para cálculo constante na norma DNER ME 024/1994 considera a deflexão máxima e a deflexão a $25 \mathrm{~cm}$ do ponto de aplicação da carga. As medidas de deflexão do trecho experimental foram realizadas com equipamento FWD, cujos geofones de obtenção da bacia de deflexão estão distribuídos nas seguintes distâncias do ponto de aplicação da carga: 0, 20, 30, 45, 65, 90 e 120 cm; assim, o valor para a distância de $25 \mathrm{~cm}$, requerida na Eq. (3), é obtido por interpolação linear das medidas nas distancias de 20 e $30 \mathrm{~cm}$.

$$
R=\frac{6250}{2 *\left(D_{0}-D_{25}\right)}
$$

Onde:

$\mathrm{R}=$ Raio de curvatura (metros)

$\mathrm{D}_{0}=$ Deflexão medida no ponto de aplicação da carga $(0,01 \mathrm{~mm})$

$\mathrm{D}_{25}=$ Deflexão medida a $25 \mathrm{~cm}$ do ponto de aplicação da carga $(0,01 \mathrm{~mm})$

A PMSP também utiliza este parâmetro na análise e dimensionamento de reforço de pavimentos flexíveis (SIURB - IP 09). A Figura 83 mostra os resultados médios do raio de curvatura em quatro campanhas de deflexão, nos três segmentos reciclados com adição de cimento e com camada de microrrevestimento (avaliação da camada reciclada, sem o efeito de camada de revestimento com incremento estrutural). 


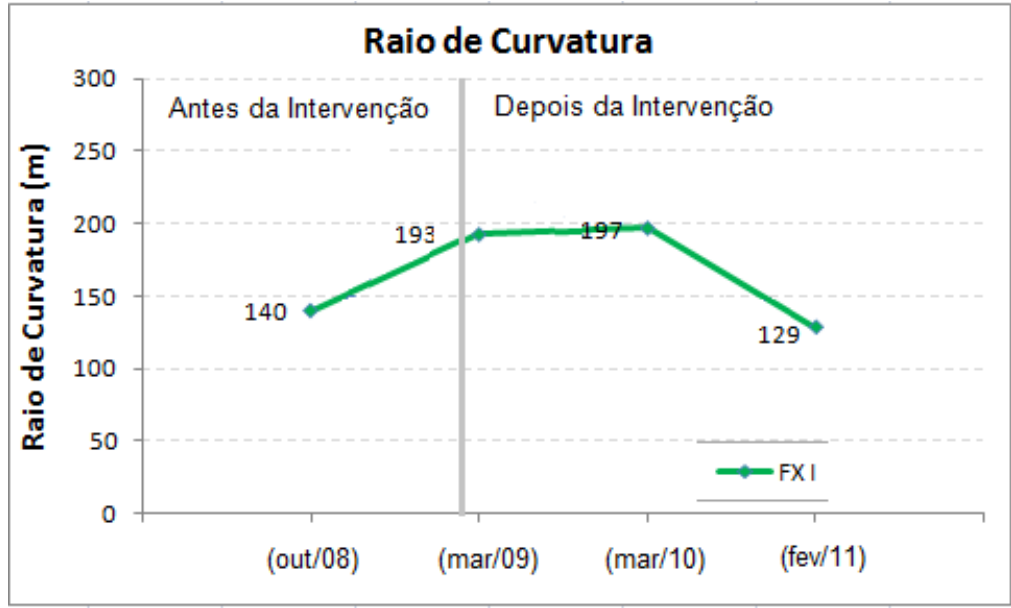

Figura 83 - Raio de curvatura médio nos segmentos com microrrevestimento em função de quatro campanhas de medidas de deflexão

Quanto maior o raio de curvatura, melhor é considerada a distribuição de cargas na estrutura. O método DNER PRO 11/79 define limite mínimo para este parâmetro em 100. Como tendência observada nas medidas de deflexão, o raio de curvatura tem um aumento significativo após a restauração, e durante a vida em serviço, os valores diminuem.

Observa-se que após um ano de vida em serviço, o raio de curvatura diminuiu, mas não se compara ainda à condição deteriorada observada antes da intervenção, apontando mais uma vez a possibilidade de colocação de camada de revestimento de maior espessura após um ano de tráfego atuante.

\subsubsection{Estimativa de Vida Remanescente - PRO 11/79}

Em análise a partir das medidas de deflexão, foi utilizado para o cálculo do número $\mathrm{N}$, o modelo de fadiga constante no método PRO 11/79, conforme Eq. (4).

$$
N=1,263 * 10^{17} * D^{-5,628}
$$

Sendo:

$N$ = número $\mathrm{N}$ equivalente de operações do eixo padrão; 
$\mathrm{D}=$ deflexão admissível, que no caso, foi substituída pela deflexão obtida imediatamente após a restauração e pela deflexão depois de um ano de tráfego atuante.

Tendo em vista que para os segmentos com camada reciclada em $15 \mathrm{~cm}$, houve uma inversão nas medidas de deflexão média (março/2009 $=59,1 \times 10^{-2} \mathrm{~mm}-\mathrm{e}$ março/2010 $=57,0 \times 10^{-2} \mathrm{~mm}$ ), o segmento não foi considerado no cálculo no número $\mathrm{N}$. Importante ressaltar que essa inversão não foi associada à deterioração do pavimento, mas ao fato de que foi instalado um dreno transversal no período entre as duas medidas de deflexão, e que pode ter contribuído para melhor drenagem, reduzindo as deflexões, que poderiam ser menores se esta execução fosse feita anteriormente a março/2009, mas que foram afetadas novamente pela drenagem ineficiente. A Tabela 19 apresenta os dados de comparação entre a vida útil remanescente imediatamente após a intervenção e após um ano da intervenção com o tráfego atuante no mesmo período, calculado a partir da contagem de pedágio, conforme discutido no item 4.2.2.

Tabela 19 - Comparação de vida útil baseada nas deflexões e do $\mathrm{N}$ atuante real no ano de 2009 - Método PRO 11/79

\begin{tabular}{|c|c|c|c|c|c|c|}
\hline $\begin{array}{c}\text { Espessura } \\
\text { Reciclada }\end{array}$ & $\begin{array}{c}\text { Deflexão } \\
0,01 \mathrm{~mm}\end{array}$ & $\begin{array}{c}\mathrm{N} \text { adm } \\
\text { Calculado }\end{array}$ & $\begin{array}{c}\text { Deflexão } \\
0,01 \mathrm{~mm}\end{array}$ & $\begin{array}{c}\mathrm{N}^{\prime} \text { adm } \\
\text { após 1 ano }\end{array}$ & $\begin{array}{c}\Delta \mathrm{N} \\
\text { Calculado }\end{array}$ & $\begin{array}{c}\mathrm{N} \text { atuante } \\
\text { Real (1 ano) }\end{array}$ \\
\hline $8 \mathrm{~cm}$ & 68,2 & $4,8 \times 10^{6}$ & 74,1 & $3,0 \times 10^{6}$ & $1,8 \times 10^{6}$ & $1,6 \times 10^{7}$ \\
\hline $11 \mathrm{~cm}$ & 60,1 & $9,9 \times 10^{6}$ & 63,6 & $6,9 \times 10^{6}$ & $3,0 \times 10^{6}$ & $1,6 \times 10^{7}$ \\
\hline
\end{tabular}

Sendo:

$N$ admissível calculado - o resultado obtido através da equação de fadiga com deflexão medida imediatamente após a conclusão dos trabalhos de restauração; $N$ ' admissível calculado - o resultado obtido através da equação de fadiga com deflexão medida após um ano de tráfego atuante sobre a estrutura restaurada; $\Delta N$ calculado - a diferença entre $N$ e $N^{\prime}$, que seria assim, o $N$ atuante no pavimento, após um ano de tráfego atuante;

$N$ atuante real - número $\mathrm{N}$ equivalente de operações do eixo padrão, calculado a partir da contagem do tráfego, durante o período de um ano a partir da restauração. 
Tendo em vista que o $\mathrm{N}$ real atuante é cerca de 10 vezes superior ao $\mathrm{N}$ calculado, pode-se inferir que há a inaplicabilidade de modelos de fadiga existentes e usuais, nas misturas recicladas a frio. $O$ modelo utilizado, já consagrado para misturas asfálticas convencionais, não traduz o desempenho da mistura reciclada a frio. $\mathrm{O}$ número $\mathrm{N}$ admissível para o pavimento novo foi superado pelo número $\mathrm{N}$ atuante, sem a deterioração funcional e estrutural prevista pelo modelo. $O$ resultado contribui para a afirmação de que o comportamento da mistura reciclada estimada no coeficiente $\mathrm{K}$ e no número $\mathrm{N}$, não pode ser relacionado com materiais convencionais.

\subsubsection{Estimativa de Vida Remanescente - PRO 269/94}

O critério de fadiga constante no método definido pela Eq. (5) - espessuras menores do que $10 \mathrm{~cm}$, e Eq. (6) - espessuras maiores do que $10 \mathrm{~cm}$, foi utilizado para definição do número $\mathrm{N}$ admissível em função das deflexões (Tabela 17) medidas imediatamente após a intervenção, e após um ano da intervenção.

$$
\begin{array}{ll}
N=5,548 \times 10^{16} \times D^{-5,319} & (\text { esp }<10 \mathrm{~cm}) \\
N=3,036 \times 10^{13} \times \mathrm{Do}^{-3,922} & (\text { esp }>10 \mathrm{~cm})
\end{array}
$$

Sendo:

$D=$ Deflexão medida no pavimento reciclado $(0,01 \mathrm{~mm})$

$N$ = Número de solicitações admissíveis para a deflexão medida

Utilizando os mesmos dados de deflexão que foram aplicados no item 5.4.1.1 para estimativa de vida remanescente por meio do método DNER PRO 11/79, obtiveramse os resultados constantes na Tabela 20. 
Tabela 20 - Comparação de vida útil baseada nas deflexões e do $\mathrm{N}$ atuante real no ano de 2009 - Método PRO 269/94

\begin{tabular}{|c|c|c|c|c|c|c|}
\hline $\begin{array}{c}\text { Espessura } \\
\text { Reciclada }\end{array}$ & $\begin{array}{c}\text { Deflexão } \\
0,01 \mathrm{~mm}\end{array}$ & $\begin{array}{c}\mathrm{N} \text { adm } \\
\text { Calculado }\end{array}$ & $\begin{array}{c}\text { Deflexão } \\
0,01 \mathrm{~mm}\end{array}$ & $\begin{array}{c}\mathrm{N}^{\prime} \text { adm } \\
\text { após 1 ano }\end{array}$ & $\begin{array}{c}\Delta \mathrm{N} \\
\text { Calculado }\end{array}$ & $\begin{array}{c}\mathrm{N} \text { atuante } \\
\text { Real (1 ano) }\end{array}$ \\
\hline $8 \mathrm{~cm}$ & 68,2 & $9,7 \times 10^{6}$ & 74,1 & $6,3 \times 10^{6}$ & $3,4 \times 10^{6}$ & $1,6 \times 10^{7}$ \\
\hline $11 \mathrm{~cm}$ & 60,1 & $3,2 \times 10^{6}$ & 63,6 & $2,6 \times 10^{6}$ & $0,6 \times 10^{6}$ & $1,6 \times 10^{7}$ \\
\hline
\end{tabular}

Sendo:

$N$ admissível - o resultado obtido através da equação de fadiga com deflexão medida imediatamente após a conclusão dos trabalhos de restauração;

N' admissível calculado - o resultado obtido através da equação de fadiga com deflexão medida após um ano de tráfego atuante sobre a estrutura restaurada; $\Delta N$ calculado - a diferença entre $\mathrm{N}$ e $\mathrm{N}^{\prime}$, que seria assim, o $\mathrm{N}$ atuante no pavimento, após um ano de tráfego atuante;

Embora o método de dimensionamento para restauração de estruturas PRO 269/94 contemple a possibilidade de reciclagem como solução de restauração, o método foi concebido para estrutura padrão de pavimento flexível (camada asfáltica + camada granular + subleito), com ponderação sobre a espessura reciclada (maior ou menor do que $10 \mathrm{~cm}$ ). Os resultados relativos ao dano sofrido no primeiro ano se revelaram muito diferentes dos dados reais de tráfego atuante, revelando que o critério de fadiga do método é inadequado para estas misturas recicladas.

\subsubsection{Parâmetro Área da Bacia de Deflexão}

O parâmetro de área da bacia de deflexão tem sido utilizado para avaliação da forma da bacia de deflexão, sendo função da área da bacia e das medidas de deflexão, calculada de acordo com AASHTO (1993) pela Eq. (7). O parâmetro é dado em $\mathrm{cm}$, pois é função da deflexão máxima $(\mathrm{cm} \times \mathrm{mm} / \mathrm{mm})$.

$$
A=15 *\left[1+2 * \frac{D_{30}}{D_{0}}+2 * \frac{D_{60}}{D_{0}}+\frac{D_{90}}{D_{0}}\right]
$$

Onde: 
$A$ = Parâmetro Área $(\mathrm{cm})$;

$D_{0}, D_{30}, D_{60}$ e $D_{90}=$ Deflexões a partir do ponto de aplicação de carga $(0,01 \mathrm{~mm})$.

A área da bacia é, normalmente, obtida pela aproximação de formas trapezoidais sobre a curva formada pelas deflexões, representativos e ponderados entre a distância do ponto de aplicação da carga até $90 \mathrm{~cm}$. Para maior precisão dos resultados, nesta pesquisa a área foi obtida pela integral da curva, com discretização unitária. A Figura 84 demonstra as duas formas de obtenção da área de bacia.

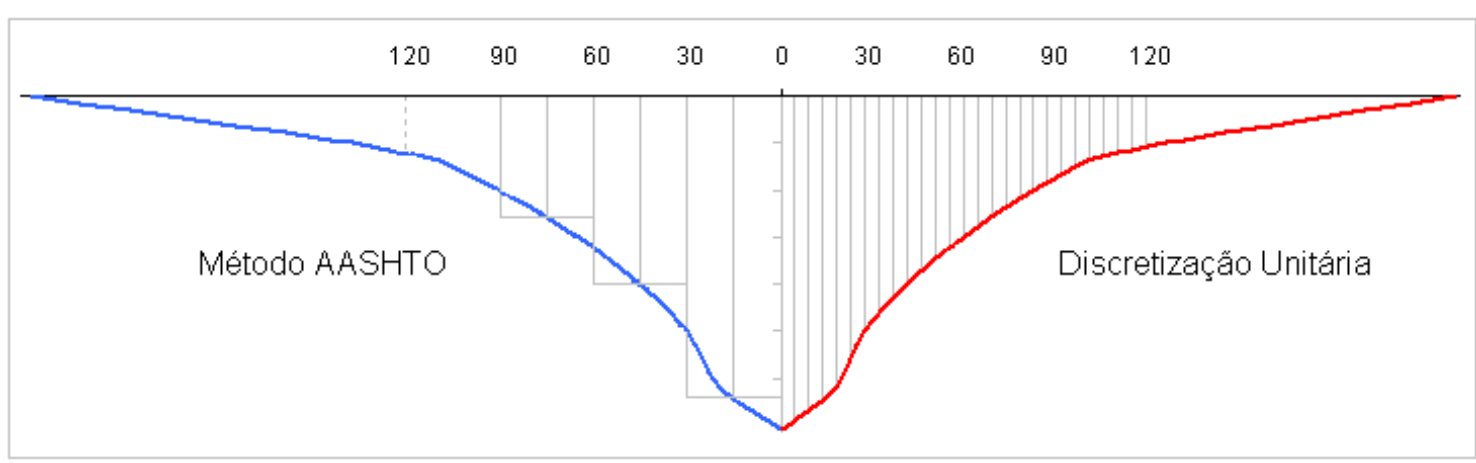

Figura 84 - Métodos para obtenção da área da bacia de deflexão

Este parâmetro, segundo o WsDOT (2005), enquadra as estruturas em faixas de desempenho de diferentes tipos de pavimentos, conforme apresentado na Tabela 21:

Tabela 21 - Faixas de Classificação do Parâmetro Área da Bacia de Deflexão (WsDOT/2005)

\begin{tabular}{|c|c|}
\hline Pavimento tipo & Área (cm) \\
\hline Pavimento Rígido de Concreto - CCP & $60-90$ \\
\hline Pavimento em Concreto Asfáltico Espesso > $12 \mathrm{~cm}$ & $55-75$ \\
\hline Pavimento em Concreto Asfáltico Delgado < $12 \mathrm{~cm}$ & $40-55$ \\
\hline Pavimentos Flexíveis Fracos & $28-40$ \\
\hline
\end{tabular}

Os resultados médios são apresentados na Tabela 22, para a faixa I do trecho experimental. O parâmetro é pouco difundido no país, e carente de avaliações mais aprofundadas. Observa-se que falta coerência nos resultados, uma vez que a estrutura antes da intervenção tem valores mais elevados no parâmetro área, sugerindo comportamento similar ao comportamento de pavimentos rígidos. A camada de revestimento existente deteriorada apresentava oxidação que pode 
indicar alta rigidez e alto módulo de resiliência, contudo a distribuição de tensões não corresponde a um pavimento rígido apesar da rigidez da camada.

Tabela 22 - Resultados médios do Parâmetro Área para cada segmento, em quatro campanhas de medição deflectométrica

\begin{tabular}{|c|c|c|c|c|c|c|}
\cline { 2 - 7 } \multicolumn{1}{c|}{} & $\mathrm{AC}+8$ & $\mathrm{AC}+11$ & $\mathrm{AC}+15$ & $\mathrm{MS}+15$ & $\mathrm{MS}+11$ & $\mathrm{MS}+8$ \\
\hline out/08 & 81,80 & 79,96 & 83,19 & 87,47 & 69,12 & 74,86 \\
\hline $\mathrm{mar} / 09$ & 63,63 & 59,98 & 57,19 & 67,41 & 59,03 & 72,39 \\
\hline $\mathrm{mar} / 10$ & 49,32 & 46,96 & 47,64 & 62,49 & 53,35 & 63,73 \\
\hline $\mathrm{fev} / 11$ & 48,31 & 48,23 & 46,66 & 42,88 & 44,59 & 45,61 \\
\hline
\end{tabular}

Os resultados do cálculo do parâmetro área para as quatro campanhas de medida de deflexão mostraram que o parâmetro é pouco preciso na avaliação da forma da bacia; contudo mostra ligeira variação da deterioração com o tempo, e ainda que os resultados são mais baixos para os segmentos com microrrevestimento.

\subsection{Determinação do Módulo de Resiliência da Mistura Reciclada}

As estimativas dos valores de módulo da camada reciclada são cruciais para a compreensão do efeito desta camada na estrutura, além de ser uma informação vital para o correto dimensionamento de projetos de restauração que contemplem o uso de misturas recicladas a frio. No entanto, existem muitos problemas para esta definição, especialmente no que se refere à calibração de dados entre campo e laboratório, particularmente pela dificuldade de reprodução em laboratório de condições correlacionáveis ao campo, de preparação do material e de aplicação de carga.

Os valores de deflexão medidos no pavimento serão utilizados para análise das tensões e deformações atuantes na estrutura e, ainda na estimativa das propriedades das camadas que constituem o pavimento.

Apesar da correção das deflexões pela temperatura e pela carga, os valores mostram que a variação sazonal tem influência sobre o desempenho do pavimento face aos condicionantes destrutivos, sendo importante identificar claramente os 
períodos em que o conjunto se apresenta mais seco (junho) ou mais úmido (março). Nas medidas de laboratório, entretanto, estas ponderações não foram realizadas, tendo-se um valor único para cada método utilizado.

\subsubsection{Determinação por Retroanálise}

A retroanálise é uma avaliação mecanística, que usualmente avalia as deflexões na superfície da estrutura analisada, associadas aos módulos das camadas (WsDOT, 2005). Além das medidas de deflexão, são necessárias as espessuras de cada camada constituinte. Para esta análise, pressupõe-se que as camadas sejam homogêneas, elásticas lineares e isotrópicas.

Nesta pesquisa foi utilizado o programa Elsym 5 - Elastic Layered System - para retroanálise. A seguir são apresentadas as estruturas com camada em microrrevestimento simuladas, a partir das deflexões relativas a março/2009, de modo que se possa obter o módulo de resiliência efetivo da camada reciclada, sem a influência da camada de revestimento (CBUQ).

Estrutura antes da intervenção, com revestimento deteriorado, a partir de medidas de deflexão realizadas no mês de outubro de 2008 (Figura 85).
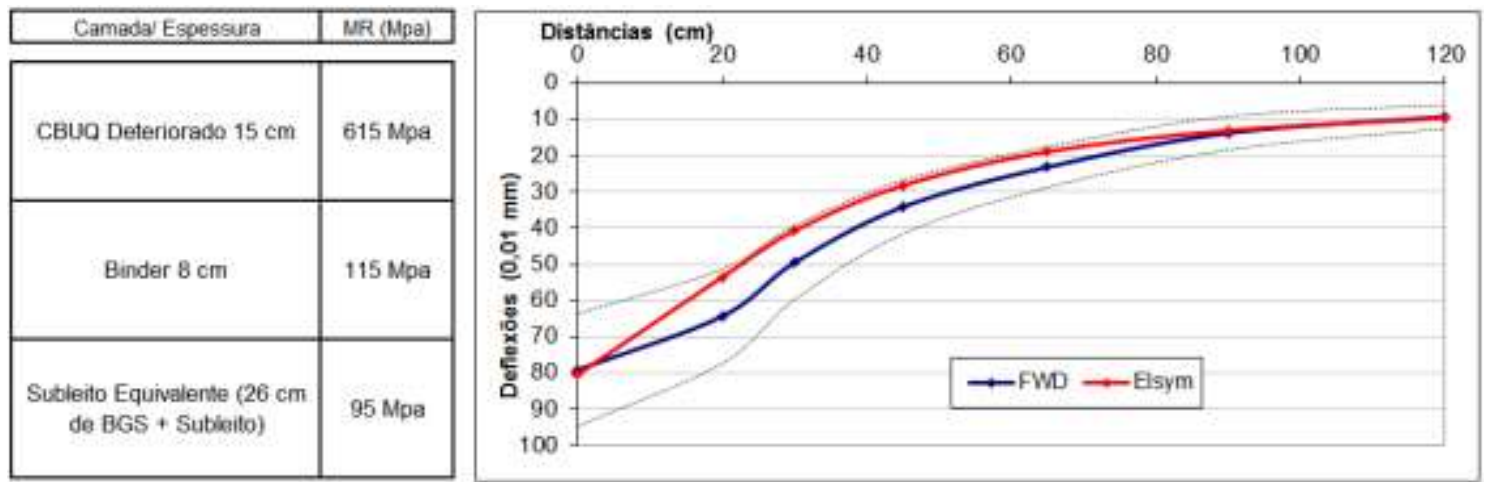

Figura 85 - Retroanálise da estrutura antes da intervenção

Estrutura após intervenção com reciclagem em $8 \mathrm{~cm}$ e $7 \mathrm{~cm}$ da camada de revestimento deteriorado remanescente (Figura 86). 


\begin{tabular}{|c|c|}
\hline Camadar Espessura & MR (Mpa) \\
\hline Reciclado $8 \mathrm{~cm}$ & $1.350 \mathrm{Mpa}$ \\
\hline CBuO Deteriorado $7 \mathrm{~cm}$ & $620 \mathrm{Mpa}$ \\
\hline Binder $8 \mathrm{~cm}$ & $115 \mathrm{Mpa}$ \\
\hline & $100 \mathrm{Mpa}$ \\
\hline $\begin{array}{c}\text { Subleito Equivalente (26 cm } \\
\text { de BGS + Subieito) }\end{array}$ & \\
\hline
\end{tabular}

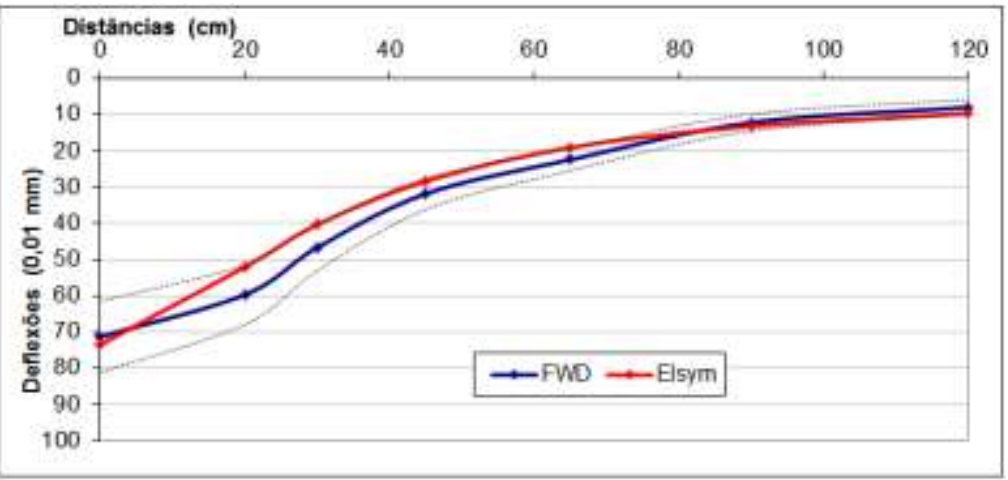

Figura 86 - Retroanálise da estrutura com camada reciclada em $8 \mathrm{~cm}$, após a intervenção

Estrutura após intervenção, com reciclagem em $11 \mathrm{~cm}$ e $4 \mathrm{~cm}$ da camada de revestimento deteriorado remanescente (Figura 87).

\begin{tabular}{|c|c|}
\hline Camiada Espessura & MR (Mpa) \\
\hline Reciclado $11 \mathrm{~cm}$ & 1.000 Mpe \\
\hline CBuQ Deteriorado $4 \mathrm{~cm}$ & $615 \mathrm{Mpa}$ \\
\hline Binder $8 \mathrm{~cm}$ & $115 \mathrm{Mpa}$ \\
\hline $\begin{array}{c}\text { Subleito Equivelente (26 cm } \\
\text { de BGS + Subleito) }\end{array}$ & $95 \mathrm{Mpa}$ \\
\hline
\end{tabular}

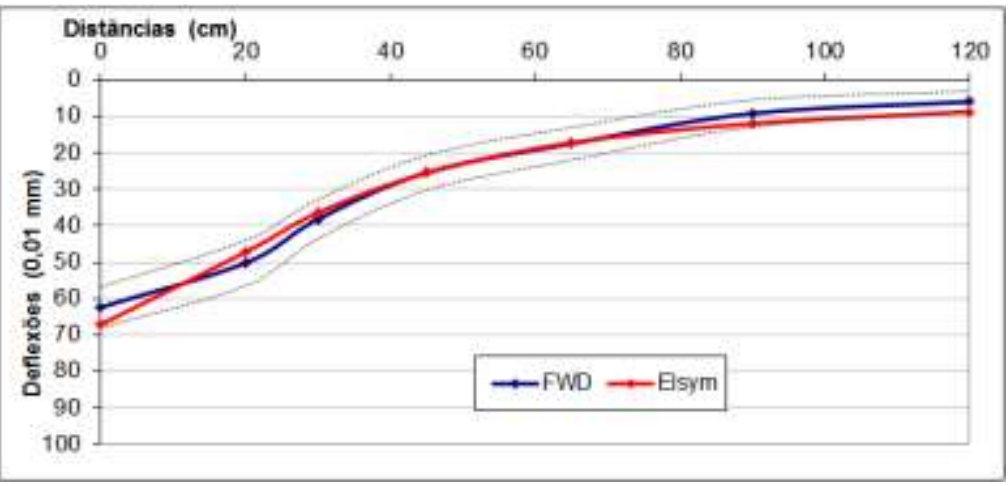

Figura 87 - Retroanálise da estrutura com camada reciclada em $11 \mathrm{~cm}$, após a intervenção

Estrutura após intervenção com camada reciclada em $15 \mathrm{~cm}$ (Figura 88).

\begin{tabular}{|c|c|}
\hline Camada' Espessura & MR (Mpa) \\
\hline Reciclado $15 \mathrm{~cm}$ & $1.050 \mathrm{Mpa}$ \\
\hline Binder $8 \mathrm{~cm}$ & $115 \mathrm{Mpa}$ \\
\hline $\begin{array}{c}\text { Subleito Equivalente (26 cm } \\
\text { de BGS + Subleits) }\end{array}$ & $95 \mathrm{Mpa}$ \\
\hline
\end{tabular}

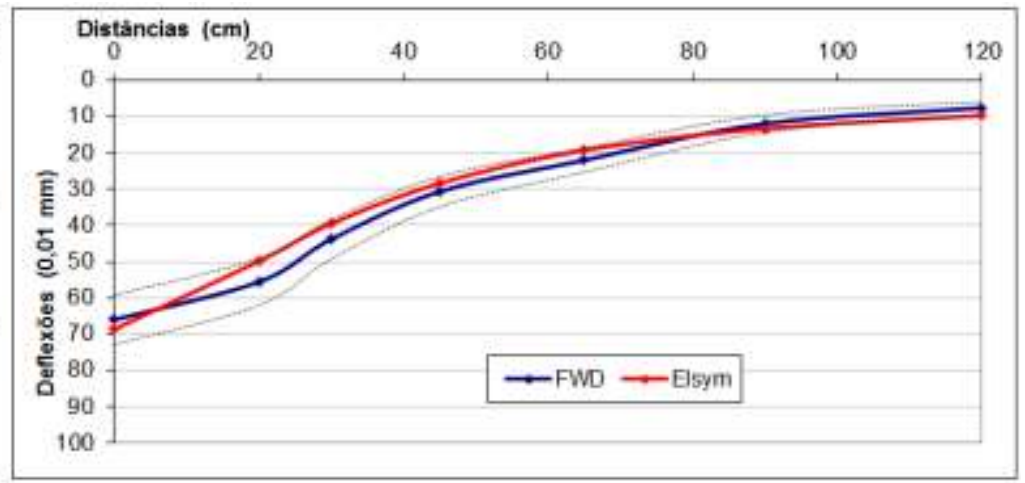

Figura 88 - Retroanálise da estrutura com camada reciclada em $15 \mathrm{~cm}$, após a intervenção Com a finalidade de verificação da sensibilidade da mistura reciclada, foram realizadas retroanálises para as mesmas estruturas (com camada de revestimento em microrrevestimento) a partir das deflexões de junho/2009. Conforme 
mencionado, as medidas realizadas em junho apresentaram redução das deflexões em relação a março, em função das características climáticas (período seco e com temperaturas mais baixas), indicando que a capacidade de suporte foi aumentada, neste período.

Estrutura após intervenção com reciclagem em $8 \mathrm{~cm}$ e $7 \mathrm{~cm}$ da camada de revestimento deteriorado remanescente, para as deflexões relativas a junho/2009 (Figura 89).

\begin{tabular}{|c|c|}
\hline Camada' Espessura & MR (Mpa) \\
\hline Reciclado $8 \mathrm{~cm}$ & $1.450 \mathrm{Mpa}$ \\
\hline CeuQ Deteriorado $7 \mathrm{~cm}$ & $650 \mathrm{Mpa}$ \\
\hline Binder $8 \mathrm{~cm}$ & $120 \mathrm{Mpa}$ \\
\hline \\
$\begin{array}{c}\text { Subleito Equivalente (26 cm } \\
\text { de BGS + Subleito) }\end{array}$ & $120 \mathrm{Mpa}$ \\
\hline
\end{tabular}

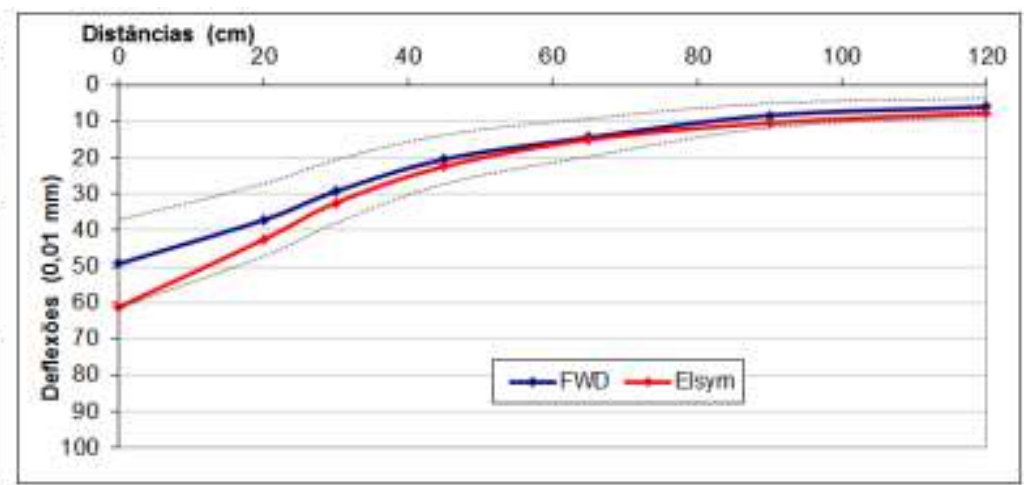

Figura 89 - Retroanálise da estrutura com camada reciclada em $8 \mathrm{~cm}$, a partir das deflexões de junho/2009, após a intervenção

Estrutura após intervenção com reciclagem em $11 \mathrm{~cm}$ e $4 \mathrm{~cm}$ da camada de revestimento deteriorado remanescente, para as deflexões relativas a junho/2009 (Figura 90).

\begin{tabular}{|c|c|}
\hline Camada Espessura & MR (Mpa) \\
\hline Reciclado $11 \mathrm{~cm}$ & $1.250 \mathrm{Mpa}$ \\
\hline CBUQ Deteriorado $4 \mathrm{~cm}$ & $615 \mathrm{Mpa}$ \\
\hline Binder $8 \mathrm{~cm}$ & $105 \mathrm{Mpa}$ \\
\hline $\begin{array}{c}\text { Subleito Equivalente }\langle 26 \mathrm{~cm} \\
\text { de BGS + Subleito) }\end{array}$ & $110 \mathrm{Mpa}$ \\
\hline
\end{tabular}

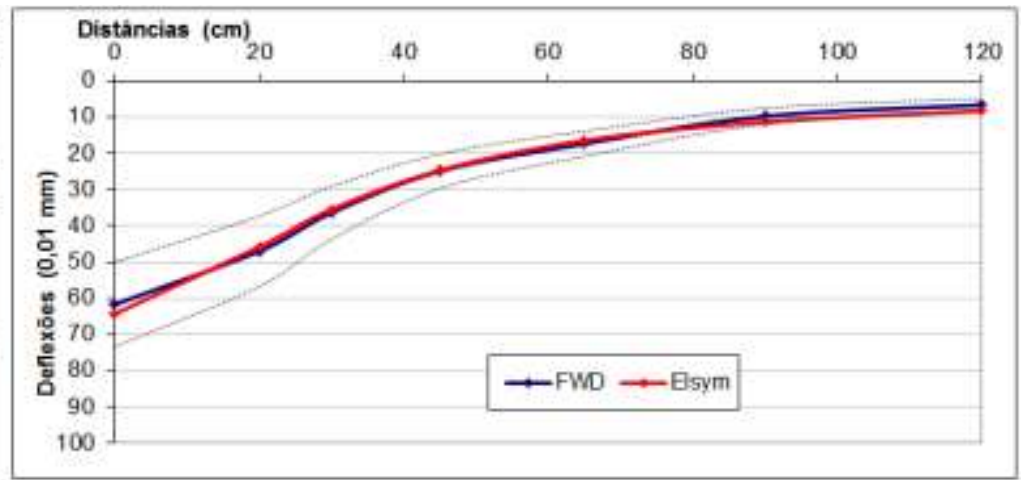

Figura 90 - Retroanálise da estrutura com camada reciclada em $11 \mathrm{~cm}$, a partir das deflexões de junho/2009, após a intervenção 
Estrutura após intervenção com camada reciclada em $15 \mathrm{~cm}$, para as deflexões relativas a junho/2009 (Figura 91).

\begin{tabular}{|c|c|}
\hline Camada Espessura & MR (Mpa) \\
\hline Reciclado $15 \mathrm{~cm}$ & $1.150 \mathrm{Mpa}$ \\
\hline Binder $8 \mathrm{~cm}$ & $120 \mathrm{Mpa}$ \\
\hline $\begin{array}{c}\text { Subleito Equivalenle (26 cm } \\
\text { de BGS + Subieito) }\end{array}$ & $1150 \mathrm{Mpe}$ \\
\hline
\end{tabular}

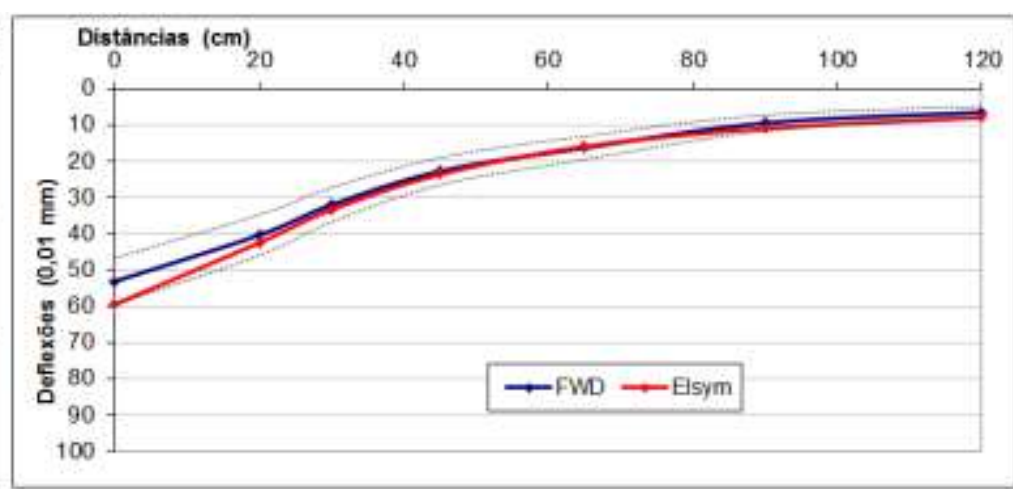

Figura 91 - Retroanálise da estrutura com camada reciclada em $15 \mathrm{~cm}$, a partir das deflexões de junho/2009, após a intervenção

Observou-se aumento no módulo efetivo da camada reciclada para as três estruturas avaliadas, revelando que esta camada é sensível às condições climáticas e, por conseguinte, à capacidade de suporte das camadas subjacentes. A Tabela 23 apresenta o resumo dos módulos de resiliência obtidos por retroanálise.

Tabela 23 - Resumo dos módulos de resiliência obtidos por retroanálise

\begin{tabular}{|c|c|c|}
\hline $\begin{array}{c}\text { Período de } \\
\text { medidas } \\
\text { deflectométricas }\end{array}$ & $\begin{array}{c}\text { Espessura da } \\
\text { camada Reciclada }\end{array}$ & $\begin{array}{c}\text { Módulo de } \\
\text { Resiliência (MPa) }\end{array}$ \\
\hline \multirow{2}{*}{$\begin{array}{c}\text { Março/2009 } \\
\text { Chuvoso }\end{array}$} & $8 \mathrm{~cm}$ & 1.350 \\
\cline { 2 - 3 } & $11 \mathrm{~cm}$ & 1.000 \\
\hline \multirow{2}{*}{$\begin{array}{c}\text { Junho/2009 } \\
\text { Seco }\end{array}$} & $15 \mathrm{~cm}$ & 1.050 \\
\cline { 2 - 3 } & $11 \mathrm{~cm}$ & 1.450 \\
\cline { 2 - 3 } & $15 \mathrm{~cm}$ & 1.250 \\
\hline
\end{tabular}

As retroanálises indicaram que o módulo da mistura reciclada varia entre $1.000 \mathrm{MPa}$ e $1.450 \mathrm{MPa}$. A camada reciclada em $15 \mathrm{~cm}$ apresentou valor de módulo menor do 
que a camada com $8 \mathrm{~cm}$, o que pode ser atribuído a dois fatores: (i) a camada com 8 $\mathrm{cm}$ recebeu mais cimento, tendo maior enrijecimento e, (ii) a camada com $15 \mathrm{~cm}$ tem menor teor de cimento e oferece maior dificuldade à compactação.

\subsubsection{Determinação pelo Método de Dimensionamento de Reforço DNER - PRO} $269 / 94$

O método de dimensionamento de reforço DNER - PRO 269/94 contempla a restauração por meio de reciclagem, definindo a espessura de reforço necessária. Nesta pesquisa, procurou-se obter os módulos de resiliência da mistura reciclada, bem como da camada remanescente em CBUQ deteriorado através das espessuras existentes da restauração por reciclagem e das deflexões medidas imediatamente após a intervenção.

A Eq. (8) foi utilizada para determinação do Módulo de Resiliência Efetivo do revestimento existente, com variação no tipo de solo para espessura de camada granular menor do que $45 \mathrm{~cm}$.

$$
\log M E F=11,19-2,753 \log D_{C}-1,714 \log H_{E}-0,0053 I_{1}+0,2766 I_{2}
$$

Sendo:

Mef - o módulo efetivo do revestimento existente deteriorado;

$D c$ - a deflexão característica, que neste estudo foi considerada a deflexão medida imediatamente após a intervenção sobre a camada reciclada com camada de revestimento em microrrevestimento ;

He - espessura da camada reciclada $(8 \mathrm{~cm}, 11 \mathrm{~cm}$ e $15 \mathrm{~cm})$;

$I_{1}$ - constante relativa à resiliência do tipo de solo do subleito da estrutura (tipo I $\rightarrow \mathrm{I}_{1}=0$, tipo II $\rightarrow \mathrm{I}_{1}=1$, tipo III $\rightarrow \mathrm{I}_{1}=0$ );

$I_{2}$ - constante relativa à resiliência do tipo de solo do subleito da estrutura (tipo I $\rightarrow \mathrm{I}_{2}=0$, tipo II $\rightarrow \mathrm{I}_{2}=0$, tipo III $\rightarrow \mathrm{I}_{2}=1$ ).

Os resultados dos valores de módulo efetivo da camada remanescente e módulo efetivo da camada reciclada são apresentados na Tabela 24. 
Tabela 24 - Resultados de Módulo de Resiliência - DNER PRO 269/94

\begin{tabular}{|c|c|c|c|c|c|}
\hline $\begin{array}{c}\text { Espessura } \\
\text { de reforço (h) }\end{array}$ & \multicolumn{2}{|c|}{$\begin{array}{c}\text { Deflexão adm. } \\
\text { aplicada }\end{array}$} & Solo tipo & $\begin{array}{c}\text { MR Reciclado } \\
\text { (MPa) }\end{array}$ & $\begin{array}{c}\text { MR CBUQ } \\
\text { Deteriorado(MPa) }\end{array}$ \\
\hline 8 & $\mathrm{D}_{0}$ & 66,4 & $\mathrm{I}$ & 2.190 & 1.590 \\
\hline 11 & $\mathrm{D}_{0}$ & 53,0 & $\mathrm{I}$ & 2.900 & 2.674 \\
\hline 15 & $\mathrm{D}_{0}$ & 59,1 & $\mathrm{I}$ & 2.300 & 1.990 \\
\hline \hline 8 & $\mathrm{D}_{0}$ & 66,4 & $\mathrm{I}$ & 2.020 & 1.572 \\
\hline 11 & $\mathrm{D}_{0}$ & 53,0 & $\mathrm{I}$ & 2.800 & 2.642 \\
\hline 15 & $\mathrm{D}_{0}$ & 59,1 & $\mathrm{I}$ & 2.200 & 1.960 \\
\hline
\end{tabular}

Observa-se que os valores de módulos obtidos por meio deste método, são consideravelmente mais elevados do que os outros métodos avaliados (retroanálise e laboratorial), inclusive os módulos da camada de CBUQ deteriorado. As variações são atribuídas à concepção do método que embora contemple a reciclagem, considerou valores de módulo da camada oxidada na ordem de $6.000 \mathrm{MPa}$.

\subsubsection{Determinação do Módulo de Resiliência em Laboratório}

Duas condições foram amostradas em laboratório, para a obtenção do módulo de resiliência: (i) ensaio triaxial em corpo de prova cilíndrico nas medidas de $10 \times 20 \mathrm{~cm}$, compactado como material granular em cinco camadas com energia intermediária de compactação e aplicação de tensão de confinamento durante a realização do ensaio e, (ii) ensaio por compressão diametral em corpos de prova extraídos do trecho experimental por sonda rotativa, e faceado nas dimensões Marshall. Cada condição apresenta características específicas que devem ser ponderadas para compreensão dos resultados. Os resultados são sintetizados na Tabela 25.

Tabela 25 - Resumo dos resultados de Módulo de Resiliência obtidos em laboratório

\begin{tabular}{|l|c|c|c|}
\hline \multicolumn{1}{|c|}{ Ensaio - Carregamento } & Moldagem & $\begin{array}{c}\text { Dimensões } \\
\mathrm{cm}\end{array}$ & $\begin{array}{c}\text { MR médio } \\
\mathrm{MPa}\end{array}$ \\
\hline Módulo - Triaxial & Laboratório & $10 \times 20$ & 1.200 \\
\hline Módulo - Compressão Diametral & Pista & $6,35 \times 10$ & 1.245 \\
\hline
\end{tabular}


A variação dos resultados de módulo com carregamento triaxial em relação aos resultados de módulo por compressão diametral é pouco significativo e ambos servem como parâmetro de comparação para projetos. O módulo triaxial revelou efeito sutil da tensão de confinamento.

\subsubsection{Comparativo de Módulo de Resiliência da Camada Reciclada}

Os módulos de resiliência foram obtidos a partir de três métodos distintos resumidos na Tabela 26: (i) em laboratório por meio de corpos de prova extraídos do trecho experimental e corpos de prova moldados em laboratório (ii) pelo método PRO 269, em função das deflexões medidas em campo e, (iii) por retroanálise em função das deflexões medidas em campo.

Tabela 26 - Resumo dos Módulos de Resiliência

\begin{tabular}{|c|c|}
\hline Tipo de Determinação & Módulo de Resiliência \\
\hline Laboratório & 1.200 a $1.300 \mathrm{Mpa}$ \\
\hline Método PRO $269 / 94$ & 1.500 a $2.600 \mathrm{Mpa}$ \\
\hline Retroanálise & 1.000 a $1.500 \mathrm{Mpa}$ \\
\hline
\end{tabular}

Conforme mencionado no item 5.5.3, os resultados de módulo de resiliência obtidos em laboratório por meio de carregamento triaxial, são os mais coerentes em relação ao módulo efetivo da mistura reciclada aplicada em campo por incluir o efeito da tensão de confinamento. Este resultado pode ser utilizado como calibração campolaboratório.

O método do DNER PRO 269/94 possui uma série de variáveis inerentes à elaboração do método. Os valores de módulo foram considerados muito elevados por comparação com os demais resultados. Os resultados apontados na retroanálise a partir das medidas de deflexão realizadas no trecho experimental são coerentes com o módulo triaxial de laboratório, e refletem a condição mais real (de campo). 
Como módulo efetivo da mistura reciclada, módulo que traduz seu comportamento na estrutura específica em análise (com camada de microrrevestimento), foi considerado o obtido por retroanálise, com variação entre $1.000 \mathrm{MPa}$ e $1.500 \mathrm{MPa}$.

\subsection{Efeito da Camada de Rolamento}

Como análise de sensibilidade, a fim de se compreender os efeitos nas distribuições de tensões em estruturas com camadas recicladas com módulo de $1.500 \mathrm{MPa}$ e diferentes espessuras de revestimento em CBUQ, foram feitas simulações no programa Elsym 5. Foram consideradas as seguintes variáveis:

- Espessura da camada reciclada: $8 \mathrm{~cm}, 11 \mathrm{~cm}$ e $15 \mathrm{~cm}$;

- Módulo equivalente do subleito: $100 \mathrm{MPa}$ e $300 \mathrm{MPa}$;

- Espessura de revestimento sobre a camada reciclada: $3 \mathrm{~cm}, 4 \mathrm{~cm}, 5 \mathrm{~cm}, 6$ $\mathrm{cm}, 8 \mathrm{~cm}, 10 \mathrm{~cm}$ e $12 \mathrm{~cm}$.

Os resultados de cada simulação são apresentados no Anexo I.

A comparação do efeito do módulo do subleito mostrou que as tensões atuantes na camada reciclada são drasticamente afetadas pela capacidade de suporte das camadas subjacentes, independente da espessura de camada de CBUQ sobre a camada reciclada. A comparação do comportamento com diferentes módulos equivalentes do subleito é apresentada na Figura 92. Considerações devem ser feitas em projeto, quando os pavimentos candidatos à reciclagem apresentarem deflexões muito elevadas. 

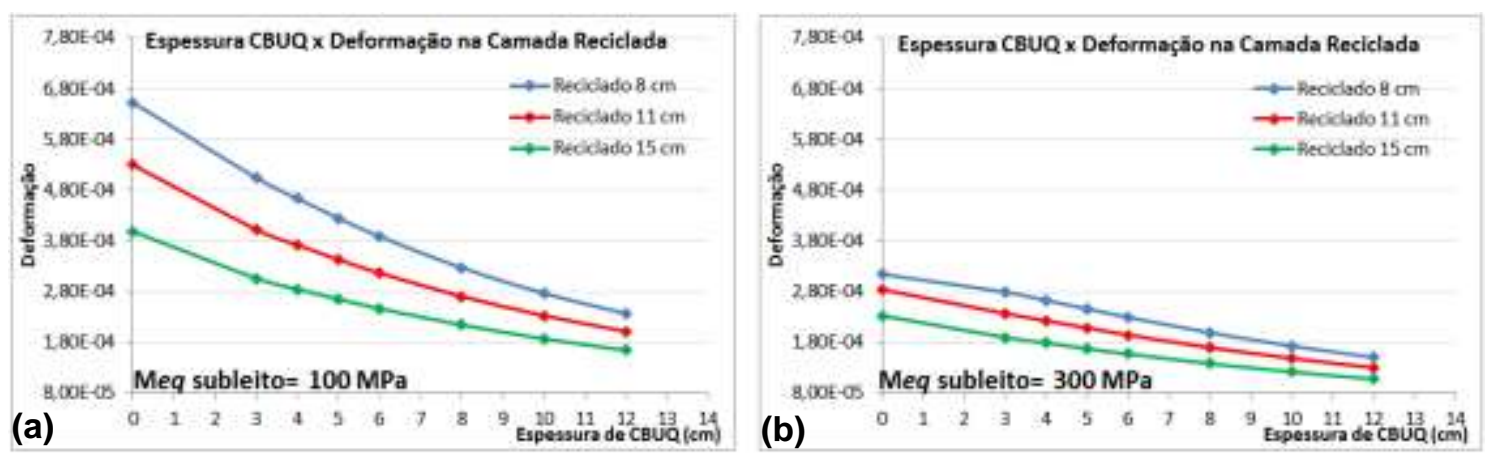

Figura 92 - Efeito da espessura de CBUQ na variação da deformação, com subleito em módulo equivalente de $100 \mathrm{MPa}$ (a) e de $300 \mathrm{MPa}$ (b)

Deve-se procurar também, medir as deflexões sobre o pavimento, após a fresagem e antes da execução da camada reciclada. Quando existe baixa capacidade de suporte das camadas subjacentes à camada reciclada, é necessário executar uma camada muito robusta em CBUQ sobre a camada reciclada, que atue de modo compensatório, entretanto há aumento na deformação do CBUQ.

A avaliação do aumento da espessura de CBUQ sobre a camada reciclada mostrou que há redução considerável da deformação na mistura reciclada o que aumenta o número $\mathrm{N}$ de solicitações suportado (Figura 93).

De acordo com o critério de fadiga em função da deformação na fibra inferior da camada reciclada, pela FHWA, esta deformação deve ser máxima de $1,10 \times 10^{-4}$, para este número $\mathrm{N}$ de projeto de 8,73E+07 (AASHTO) para um período de 8 anos, definido nesta pesquisa.

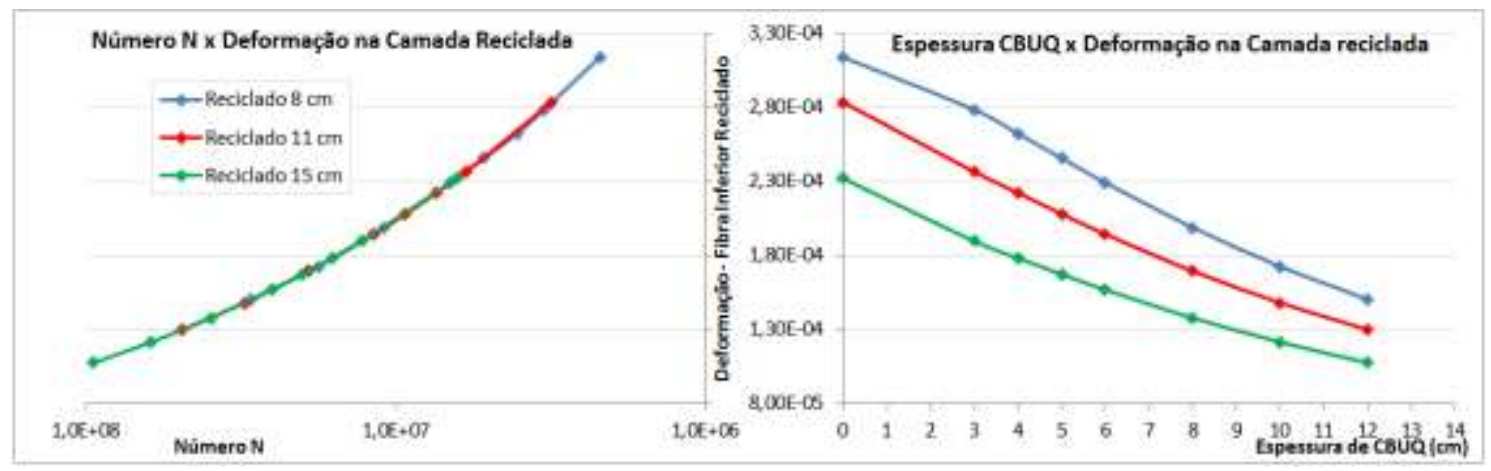

Figura 93 - Efeito da variação da espessura de revestimento e da espessura reciclada na deformação do camada reciclada e no número $\mathrm{N}$ admissível 
Quando for considerada a execução de camada reciclada sobre camadas com baixa capacidade de suporte, deve-se avaliar com critério o aumento da espessura do revestimento, pois este pode ter maiores deformações, sendo necessário avaliar qual a máxima espessura de revestimento que resistirá ao número $\mathrm{N}$ de projeto, através de critério de fadiga adequado. A variação da espessura de camada reciclada exerce efeito sobre as tensões atuantes na estrutura sendo a maior espessura $(15 \mathrm{~cm})$ mais eficiente na redução das deformações. 


\section{CONCLUSÕES E RECOMENDAÇÕES}

As conclusões desta pesquisa baseiam-se na análise de resultados de ensaios laboratoriais, das observações da execução em pista e do monitoramento de um trecho experimental, composto por seis segmentos diferentes, com espessuras variadas de camada reciclada a frio com emulsão asfáltica $(80,110$ e $150 \mathrm{~mm})$ e dois tipo de revestimentos asfálticos (microrrevestimento asfáltico a frio com $12 \mathrm{~mm}$ de espessura e concreto asfáltico com $40 \mathrm{~mm}$ de espessura), e estão a seguir elencadas:

A dosagem das misturas recicladas asfálticas a frio foi realizada seguindo as diretrizes para dosagem de misturas asfálticas a frio empregando emulsão, contudo o método não contempla de forma detalhada a variabilidade dos agregados fresados reciclados, que pode afetar o comportamento mecânico da mistura reciclada. Um método de dosagem exclusivo para materiais reciclados a frio deve ser concebido e normatizado em âmbito nacional.

A comparação em laboratório entre misturas recicladas com emulsão modificada por polímero e misturas recicladas com emulsão convencional revelou melhores resultados nos ensaios mecânicos em amostras com emulsão modificada. $\mathrm{O}$ teor ótimo, entretanto, não foi alterado por tal modificação da emulsão.

Observou-se que a proporção entre água e emulsão tem impactos sobre o comportamento das amostras, de modo que teores muito baixos de emulsão, para teor fixo de água, podem conduzir a resultados insatisfatórios que afetam principalmente as características associadas à adesividade. $O$ teor de água foi fixado para representar a condição de campo, na qual ocorre o lançamento de água para resfriar o cilindro fresador e mitigar a produção de pó.

O processo executivo por meio de trem de reciclagem revelou algumas deficiências no controle, principalmente associados à alta produtividade do equipamento, desprezando variabilidades de estado da camada remanescente, não permitindo correções localizadas para diminuir a variabilidade do resultado final da técnica. A 
curva granulométrica do agregado fresado é função da velocidade de avanço da fresadora e das características de deterioração da camada deteriorada a ser fresada, e tem controle apenas do diâmetro máximo, desconhecidas as demais frações. O peneiramento em laboratório revelou baixa porcentagem de finos, o que aumenta o volume de vazios e reduz a coesão da mistura.

Outro fator deficiente é a caracterização da estrutura remanescente, uma vez que o acesso é impedido pelo formato do equipamento, não sendo possível avaliar estruturalmente, por meio de deflexões, nem mesmo a integridade ou trincamento existente. A avaliação das condições da camada remanescente tem grande influência no processo, especialmente no que se refere à reflexão de trincamento para a camada reciclada e falta de suporte adequado à camada reciclada. A condição estrutural também é fundamental, pois no caso de deflexões muito elevadas, a reciclagem pode não ser indicada.

O trem de reciclagem também não permite a execução em duas camadas. A compactação da camada reciclada em $15 \mathrm{~cm}$ de espessura foi insuficiente, de modo que para espessuras mais robustas, a execução e compactação em duas camadas podem ser necessárias. Outra possibilidade é o uso de rolos compactadores mais eficientes e variações de componentes da mistura para facilitar a densificação.

A adição de cimento, no teor de 1\%, garante resistência inicial para a mistura reciclada de modo a permitir a abertura ao tráfego quase que imediatamente após reciclagem e proteção provisória da superfície. O cimento e a ruptura da emulsão resistem aos esforços do tráfego, durante o período inicial da cura do material. A execução de camada de revestimento sobre a camada reciclada deve respeitar o período de cura mínimo de 14 dias, de modo que a água tenha se evaporado na maior parte de seu conteúdo inicial. A resistência da mistura tem aumento significativo neste período e cresce com o tempo. Ensaios de módulo de resiliência em amostras de laboratório revelaram diminuição da deformabilidade (e aumento da rigidez) com o tempo de cura.

O ensaio de módulo de resiliência triaxial revelou que a mistura reciclada sofre efeito sutil do confinamento, e é parâmetro importante de comportamento para aplicação 
nos projetos. Os dados obtidos por retroanálise estrutural das bacias de deflexão demonstraram que os valores de laboratório e de campo são similares e estão entre 1.000 e $2.000 \mathrm{MPa}$. A mistura reciclada tem comportamento quanto à deformabilidade intermediário entre mistura asfáltica a quente e camada granular; a camada reciclada não demonstra a rigidez de um concreto asfáltico, mas comportase como um material coeso e de maior rigidez que uma brita graduada simples. $O$ desempenho da mistura reciclada em campo ratifica esta característica de deformabilidade.

A diminuição na irregularidade é um beneficio nas condições de conforto e segurança percebida pelo usuário. As soluções de reciclagem implementadas mostraram que se alcançaram indicadores satisfatórios de irregularidade dos pavimentos, ficando dentro das características exigidas pela ANTT.

Os segmentos que receberam microrrevestimento asfáltico a frio como camada superficial selante apresentaram bom desempenho, resistindo bem às condições climáticas e aos esforços do tráfego pesado da Rodovia Régis Bittencourt - BR 116, no trecho do km 435+500 a 434+000, sentido Curitiba - São Paulo, durante o primeiro ano de vida em serviço. Após o primeiro ano, os níveis deflectométricos aumentaram, e surgiram os primeiros defeitos significativos. Nesta etapa, observouse a necessidade da execução de camada de rolamento como incremento estrutural, sem danos extensos que pudessem reduzir a vida útil da estrutura. A irregularidade somada à condição estrutural pode ser empregada como indicativo para manutenção por etapas.

A camada em concreto asfáltico (CBUQ) mostrou-se mais adequada para este nível de tráfego elevado da rodovia e deflexões existentes. Os segmentos com camada reciclada e CBUQ não tiveram aumento significativo de deflexão e de irregularidade do primeiro para o segundo ano de operação após restauração. A verificação de espessuras mais elevadas do revestimento, através do programa Elsym 5, mostrou que o aumento das espessuras de camada reciclada e de revestimento asfáltico reduz as deformações em ambas as camadas, ampliando o período de vida útil. 
A mistura reciclada revelou boa resistência à deformação permanente em todos os segmentos. Entretanto, revelou alta sensibilidade à drenagem deficiente, sendo afetada de modo irreversível pelo acúmulo de água no pavimento. A execução de drenos antes da restauração é fator fundamental para o sucesso da técnica. Nos segmentos com revestimento em microrrevestimento asfáltico a frio, percebeu-se aumento de trincamento após um ano de vida em serviço, aumentando o volume de água que infiltra na estrutura do pavimento.

Modelos de previsão de desempenho tradicionais e em uso no país não retratam o comportamento da mistura reciclada, confirmando que o comportamento da mistura reciclada difere de misturas asfálticas a quente. A previsão de desempenho pode ser mais bem representada pela evolução das medidas de deflexão e área da bacia de deflexão, dentre outras características que devem ser estudadas, com análises aprofundadas em pesquisas futuras.

Como recomendações para futuras pesquisas:

- Realizar dosagem em laboratório por meio de compactador giratório;

- Executar em campo variações nas espessuras da camada de revestimento sobre a camada reciclada;

- Executar em campo, trechos para comparação entre misturas com emulsão convencional e com emulsão modificada por polímero;

- Verificar outros modelos de previsão de desempenho que possam responder de modo coerente o comportamento de misturas recicladas;

- Avaliar outras configurações estruturais, incluindo bases cimentadas e subleitos com diferentes capacidades de suporte. 


\section{REFERÊNCIAS BIBLIOGRÁFICAS}

AASHTO-T312. American Association of State Highway and Transportation Officials

- Preparing and determining density of hot mix asphalt (HMA) specimens by means of the superpave gyratory compactor.

ABEDA. Associação Basileira das Empresas Distribuidoras de Asfalto. Manual básico de emulsões asfálticas: Soluções para pavimentar sua cidade. Rio de Janeiro. 2001.

ABNT NBR-6465. Associação Brasileira de Normas Técnicas. Agregados Determinação da abrasão "Los Angeles". 1984.

ABNT NBR 10004/2004 - Resíduos Sólidos. Associação Brasileira de Normas Técnicas. Resíduos Sólidos. 2004.

ACADEMY, A. Technical Guideline: Bitumen Stabilised Materials. Pretoria. 2009.

ALKINS, A. E.; LANE, B.; KAZMIEROWSKI, T. Sustainable pavements: environmental, economic, and social benefits of in situ pavement recycling. Transportation Research Record: Journal of the Transportation Research Board, v. 2084, p. 100-103, 2008.

ANP. Agência Nacional do Petróleo. Regulamento Técnico N. 05 - Emulsões asfálticas catiônicas modificadas por polímeros elastoméricos. 2009.

ARRA. Asphalt Reclaming and Recycling Association. 2009. Disponível em: < http://www.arra.org/index.php?option=com_docman\&task=cat_view\&gid=39\&ltemid= 46 >. Acesso em: 11/09/2009.

ARRA, Asphalt Reclaming and Recycling Association - Basic Asphalt Recycling Manual. p. 269, 2001. 
ASTM-D93. American Society for Testing and Materials - Standard test methods for flash point by pensky-martens closed cup tester.

ASTM-D1075. American Society for Testing and Materials. Standard test method for effect of water on compressive strength of compacted bituminous mixtures.

ASTM-D2041. American Society for Testing and Materials. Standard test method for theoretical maximum specific gravity and density of bituminous paving mixtures.

ASTM-D4791. American Society for Testing and Materials. Standard test method for flat particles, elongated particles, or flat and elongated particles in coarse aggregate.

BALBINOT, J. C. Estudo de misturas asfálticas a frio do tipo grave-émulsion. 2007. (Dissertação de Mestrado). UFRGS, Porto Alegre.

BEMANIAN, S.; POLISH, P.; MAURER, G. Cold in-place recycling and full-depth reclamation projects by Nevada Department of Transportation. Transportation Research Record, v. 1949, 2006.

BERNUCCI, L. B. et al. Pavimentação Asfáltica: Formação básica para engenheiros. Rio de Janeiro: Petrobrás, ABEDA, 2007.

BETTER.ROADS. Asphalt Emulsion Manufacturers Association - Full Depth Reclamation. 2001.

BONFIM, V. Estudo da granulometria resultante da fresagem de revestimentos asfálticos com vistas à reciclagem "in situ" a frio. 1999. (Dissertação de Mestrado). Engenharia de Transportes EPUSP, São Paulo.

BONFIM, V. Fresagem de Pavimentos asfálticos. Ed. Exceção. São Paulo. 2007

BROWN\&BROWN. 2009. Disponível em: <www.brownbrown.com.br>. Acesso em: 14/05/2009. 
CARTER, A. Comparison of cold in-place recycling and full-depth reclamation materials. Transportation Record Board', p. 10, 2009.

CASTRO, L. N. Reciclagem a frio "in situ" com espuma de asfalto. 2003. 183 Dissertação de Mestrado, COPPE/ UFRJ, Rio de Janeiro.

CASTRO NETO, A. M. Proposta de projeto de dosagem de concreto betuminoso reciclado a quente. 2000. (Mestrado). Engenharia de Transportes, EPUSP, São Paulo.

CIA. The World Fact Book. 2007. Disponível em: < https://www.cia.gov/library/publications/the-

worldfactbook/rankorder/2085rank.html?countryName=France\&countryCode=fr\&regi onCode=eu\&rank=7\#fr >. Acesso em: 04/03/2009.

CLERMAN, D. D. S. Estudo laboratorial de misturas asfálticas a frio produzidas com incorporação de borracha de pneus. 2004. (Dissertação de Mestrado). UFRGS, Porto Alegre.

CNT. Boletim Estatístico. 2006. Disponível em:

<http://www.cnt.org.br/portal/img/arquivos/Boletim\%20Estatístico\%20CNT\%20\%202009.pdf >. Acesso em: 07/09/2009.

CNT. Pesquisa CNT de Rodovias 2010. 2010. Disponível em:

< http://www.sistemacnt.org.br/pesquisacntrodovias/2010/ >.

CONAMA. Conselho Nacional do Meio Ambiente. Resolução Conama n. 5 - Gestão de resíduos e produtos perigosos 1993.

CROSS, S. Determination of superpave ${ }^{\circledR}$ gyratory compactor design compactive effort for cold in-place recycled mixtures. Transportation Research Record, v. 1819, p. 152-160, 2003. 
DAMA, M. A. Analise de comportamento da camada reciclada com espuma de asfalto na Rodovia BR-290/RS. 2003. (Dissertação de Mestrado). UFRGS, Rio Grande do Sul.

DAVID, D. D. Misturas asfálticas recicladas a frio: estudo em laboratório utilizando emulsão e misturas asfálticas recicladas a frio. 2006. (Dissertação de Mestrado). UFRGS, Porto Alegre.

DER-ET-DE-P00/34. Departamento de Estradas de Rodagem. Reciclagem de pavimentos asfáltico in situ com emulsão. 2006.

DER. Fresagem de Fresagem de pavimento asfáltico - especificação técnica -, ETDE-P00/038: Departamento de estradas de Rodagem 2006.

DNER-ES-405/2000. Departamento Nacional de Estradas de Rodagem. Pavimentação - Reciclagem de pavimento a frio in situ com espuma de asfalto. Rio de Janeiro. 2000.

DNER ME 024/94. Departamento Nacional de Estradas de Rodagem. Pavimento determinação das deflexões pela viga Benkelman. Rio de Janeiro. 1994.

DNER-ME-035/98. Departamento Nacional de Estradas de Rodagem. Agregados Determinação da abrasão "Los Angeles" 1998.

DNER-ME 083/98. Departamento Nacional de Estradas de Rodagem. Agregados análise granulométrica. Rio de Janeiro. 1998.

DNER-ME-107/94. Departamento Nacional de Estradas de Rodagem. Mistura Betuminosa a frio com emulsão asfáltica - Ensaio Marshall., 1994.

DNER-ME-117/94. Departamento Nacional de Estradas de Rodagem. Mistura betuminosa - Determinação da densidade aparente. 1994. 
DNER-ME-131/94. Departamento Nacional de Estradas de Rodagem. Determinação do módulo de resiliência. 1994.

DNER-ME-133/94. Departamento Nacional de Estradas de Rodagem. Determinação do módulo de resiliência - misturas betuminosas., 1994.

DNER-ME-138/94. Departamento Nacional de Estradas de Rodagem. Misturas Betuminosas - Determinação da Resistência à tração por Compressão Diametral, 1994.

DNER-ME-383/99. Departamento Nacional de Estradas de Rodagem. Desgaste por abrasão de misturas betuminosas com asfalto polímero - Ensaio Cantabro. 1999.

DNER-273/1996-PRO. Departamento Nacional de Infra-Estrutura de Transportes. Determinação de Deflexões utilizando deflectômetro de impacto tipo "Falling Weight Deflectometer (FWD)". 1996.

DNER-PRO 011/79. Departamento Nacional de Infra-Estrutura de Transportes. Avaliação estrutural dos pavimentos flexiveis - Procedimento B. 1979.

DNER-PRO 269/94. Departamento Nacional de Infra-Estrutura de Transportes. Projeto de restauração de pavimentos flexiveis - TECNAPAV. 1994.

DNIT-031/2006-ES. Departamento Nacional de Infra-Estrutura de Transportes. Pavimentos flexiveis - Concreto asfáltico 2006.

DNIT. Manual de Restauração de Pavimentos Asfálticos: Departamento Nacional de Infra-Estrutura de Transportes 2006.

EMBRAPA. Empresa Brasileira de Pesquisa Agropecuária. 2010. Disponível em: <http://www.embrapa.br/ >. Acesso em: 17/07/2010.

EPA. Environmental Protection Agency. 2010. Disponível em: < http://www.epa.gov/lawsregs/ >. Acesso em: 12/04/2010. 
FHWA. Background of SUPERPAVE Asphalt Binder Test Methods. FHWA-SA-94069. 1994.

FHWA. Pavement Recycling Guidelines for State and Local Governments - FHWASA-98-042. ADMINISTRATION, F. H. Washington 1997.

FHWA. Recycled materials in european highway environments: Uses, Technologies, and Policies - FHWA-PL-00-025. 2000.

FHWA/IN/JTRP-2002/6. Final Report. Use of reclaimed asphalt pavement (RAP) Under Superpave Specifications., 2002.

FRESAR. Reciclagem de pavimentos: porque a técnica não é tão utilizada no Brasil? 2010. Disponível em: < http://www.fresar.com.br/fresarphp/ >. Acesso em: 18/03/2010.

GUSMÃO, C. B. Evolução temporal da resistência mecânica em laboratório, de misturas simulando a reciclagem de pavimento asfáltico com adição de cimento Portland. 2008. (Dissertação de Mestrado). Engenharia de Transportes, UNICAMP, Campinas.

HALLIN, J. P.; TENG, T. P.; SCOFIELD, L. A., QUINTUS, H. Pavement Design in the Post-AASHO Road Test Era. Transportation Research Circular, E-C118, 2007.

HUNTER, R. N. Bituminous mixtures in road construction. London: 1994.

INMET. Instituto Nacional de Metereologia. 2010. Disponível em: <http://www.inmet.gov.br/>. Acesso em: 21/09/2010.

JAMES, A. Overview of asphalt emulsions. Transportation Research Circular, 2006.

KADRMAS, A. Emulsion test methods: do we need them? Transportation Research Circular, 2006. 
KARLSSON, R.; ISACSSON, U. Material-related aspects of asphalt recycling-stateof-the-art. Journal of Materials in Civil Engineering, v. 18, p. 81, 2006.

KIM, Y.; LEE, H. D.; CECCOVILLI, R. Laboratory evaluation of engineered cir emulsion and foamed asphalt mixtures for cold-in-place recycling of asphalt pavements. p. 1-23, 2004.

LEI FEDERAL 9.985. Constituição Federal. Ministério do Meio Ambiente. 2000.

LEITE, L. F. M. Estudos de preparo e caracterização de asfaltos modificados por polímero. 1999. 269 (Doutorado). Tese, COPPE/ UFRJ, Rio de Janeiro.

LIBERATORI, L. A.; CONSTANTINO, R. S.; JR., O. T. Cold in situ recycling - at SP147. A brand new experience. International symposium on Pavement recycling. São Paulo 2005.

LOIZOS, A. Aspects concerning field curing criteria for cold-in place asphalt pavement recycling. Transportation Record Board, 2008.

LUCENA, M. D. C. C. et al. Reologia de asfaltos brasileiros puros e modificados por sbs. ANPET 2008.

MACHADO, R. Z. Asfalto modificado por polímero SBS para pavimentos drenantes. 2007. (Dissertação de mestrado). Ciência e tecnologia de materiais, UNICAMP, Campinas.

MALLICK, R. B.; KANDHAL, P. S.; BRADBURY, R. L. Using warm-mix asphalt technology to incorporate high percentage of reclaimed asphalt pavement material in asphalt mixtures. Transportation Research Record, v. 2051, 2007.

MALLICK, R. B.; O'SULLIVAN, K.; TAO, M. Why not (use rejuvenator for) 100\% rap recycling? Transportation Record Board, 2010. 
MARTÍNEZ, G. V. Experimental study of recycled asphalt misxtures with high percentages of Reclaimed Asphalt Pavement RAP). Transportation Record Board', 2010.

MnDOT. Minnesota Departament of Transportation - Hydraulic and mechanical properties of recycled materials. 2009

MnDOT. Minnesota Departament of Transportation - Cold in-place recycling. p.83. 2000.

MOREIRA, H. S. Comportamento mecânico de misturas asfálticas a frio com diferentes teores de agregado fresado incorporado e diferentes modos de compactação. 2005. (Dissertação de mestrado). Engenharia de Transportes, UFC, Fortaleza.

MORIAN, D. A.; OSWALT, J. Twenty Years Later - Experience with Cold In-Place Recycling as a Reflective Crack Control Technique. 2005

MOTTA, L. M. G.; LEITE, L. M. F. Desempenho de trechos de pavimentos acompanhados nos últimos 10 anos. IBP 2002.

MURPHY, D.; EMERY, J. Modified cold in-place asphalt recycling. Transportation Research Record, v. 1545, p. 143-150, 1996.

NLT-352. Caracterizacion de las mezclas bituminosas abiertas por medio del ensayo cántabro de pérdida por desgaste. 2000.

PIARC. Review of the growth and development of recycling In pavement construction. PIARC Technical Committee C4.3 Road Pavements. 2008.

PINTO, I. E. Estudo das características físicas e mecânicas de misturas recicladas com espuma de asfalto. 2002. (Dissertação de Mestrado). Engenharia de Transportes, EPUSP, São Paulo. 
PINTO, S. Tópicos especiais em mecânica dos pavimentos. Rio de Janeiro, RJ: COPPE/ UFRJ, 1989.

PINTO, S. Estudo do comportamento à fadiga de misturas betuminosas e aplicação na avaliação estrutural de pavimentos. Tese de Doutorado. COPPE/ UFRJ. Rio de Janeiro. 1991.

PMSP. Prefeitura Municipal de São Paulo - Lei n. 14.015 - Dispõe sobre o descarte e reciclagem de misturas asfálticas retiradas dos pavimentos urbanos municipais. 2005.

QUINTUS, H. L. V.; MALLELA, J.; BUNCHER, M. Quantification of effect of polymermodified asphalt on flexible pavement performance. Transportation Record Board, 2001.

ROGGE, D. F.; HICKS, R. G. Use of Asphalt Emulsions in-place Recycling: Oregon Experience. Transportation Record Board, 1993.

SACHET, T. Controle Tecnológico de Obras Rodoviárias Envolvendo a Reciclagem In Situ de Bases Granulares de Pavimentos Asfálticos. 2007. (Dissertação de Mestrado). Universidade de Passo Fundo, Passo Fundo.

SALOMON, D. "A green technology comes of age. LTRC Emulsion: Design, Construction, and Performance Conference. Baton Rouge, Louisiana 2008.

SANTANA, H. Instituto Brasileiro do Petróleo. Manual de pré-misturados a frio. Rio de Janeiro. 1993.

SEBAALY, P. et al. Performance of cold in-place recycling in Nevada. Transportation Research Record, v. 1896, p. 162-169, 2004.

SIURB IP-09. Secretaria de infra estrutura urbana da Prefeitura Mucinipal de São Paulo. Instrução de projeto de reforço para restauração de pavimentos flexiveis. 
SUZUKI, C. Y. et al. Structural analysis of a test section using cold in place recycling. International Symposium On Pavement Recycling. São Paulo 2005.

TAO, M.; MALLICK, R. J. An evaluation of the effects os warm mix asphalt additives on workability and mechanical properties os reclaimed asphalt pavement. Transportation Research Board, 2009.

THOMAS, T.; KADRMAS, A. Performance-related tests and specifications for cold inplace recycling : lab and field experience performance-related tests and specifications for cold in-place recycling : lab and field. North, p. 1-14, 2003.

THOMAS, T.; KADRMAS, A.; HUFFMAN, J. Cold in-place recycling on US-283 in Kansas. Transportation Research Record, 2000.

WIRTGEN GMBH. Manual de reciclagem a frio. 2a Edição, 2004.

WILLIAMS, R. D.; O'LEARY, M. D. In-situ cold recycling of bituminous pavements with polymer-modified high float emulsions. Transportation Research Board, 1992.

WOOD, L. Recycling of bituminous pavements. 1978.

WsDOT. Everseries user guide. Pavement analysis computer software and case studies. Washington State Departament of Transportation. 2005.

ZEGARRA, E. Ligantes asfálticos peruanos convencional PEN 60 / 70 e modificados por polímero SBS tipo I 60 / 60 e PG 76 -22. 2007. (Dissertação de Mestrado). InfraEstrutura de Transportes, EESC, São Carlos. 
ANEXO I

Apresenta-se no anexo I, os resultados relativos à simulação no programa Elsym 5, para diferentes condições de espessura de revestimento (CBUQ) e de espessuras de camada reciclada.
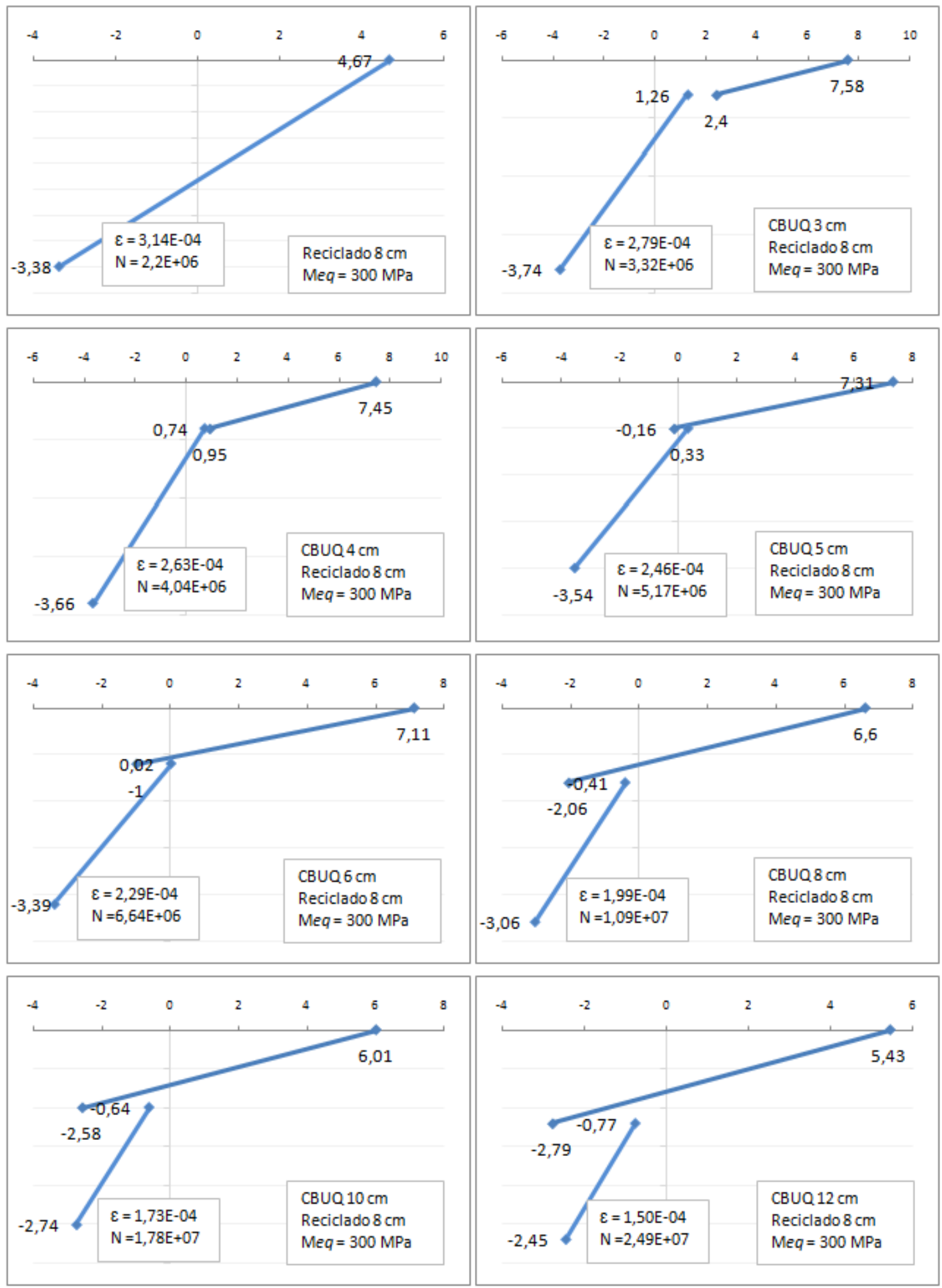

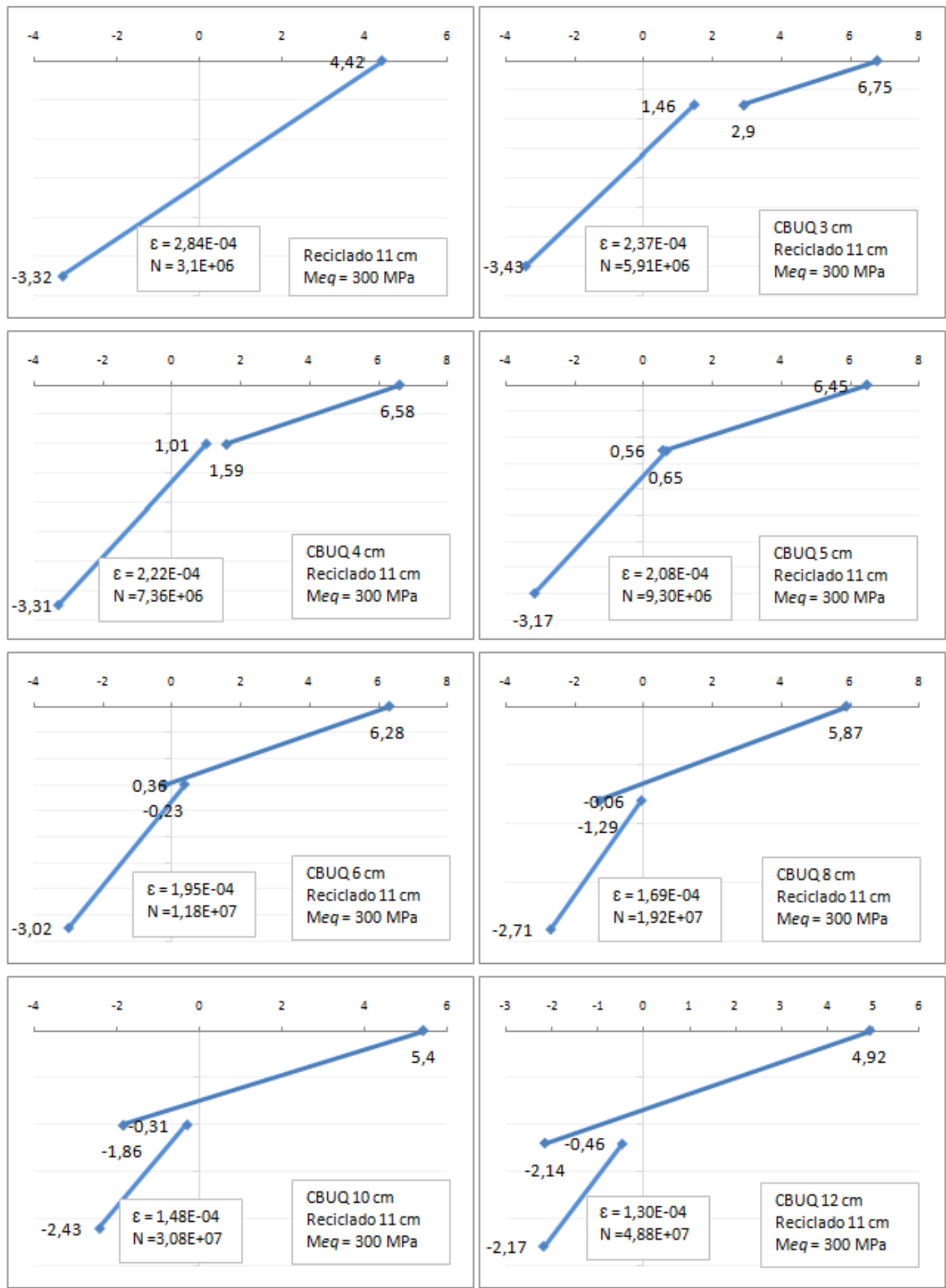

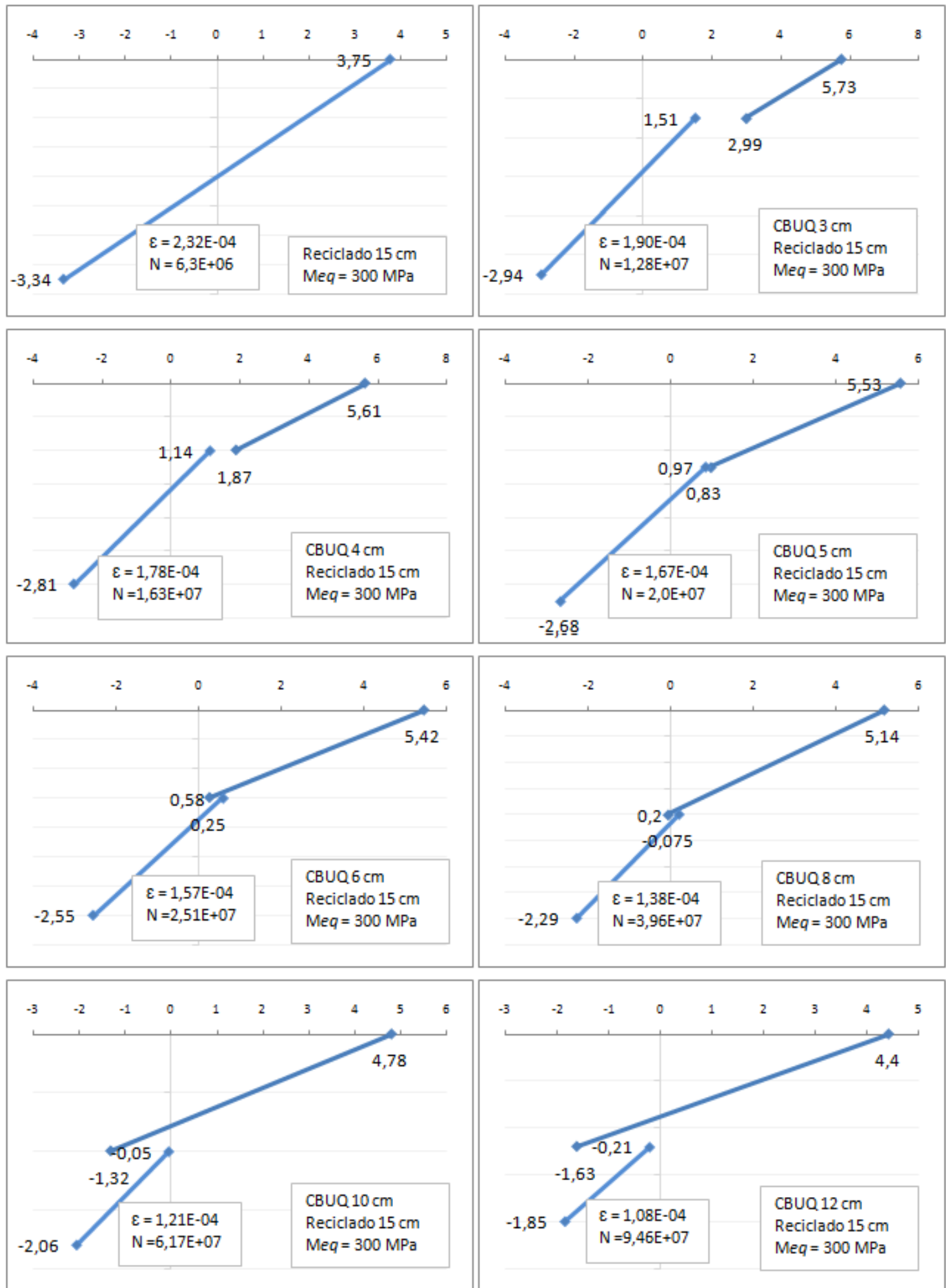